$$
\begin{aligned}
& \text { जole }{ }^{\circ} \text { al }
\end{aligned}
$$

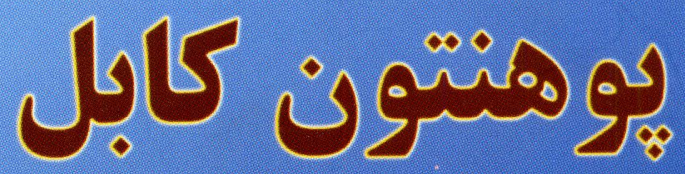

$$
\begin{aligned}
& \text { نشريه دو مالها }
\end{aligned}
$$

شماره نشم سال ردبا 


\section{هيأت تحرير}

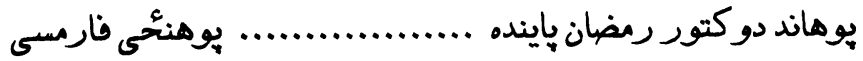

$$
\begin{aligned}
& \text { يوهاند محمد ظلريف تنيوال ................................. يوهنحى زمين شناسى }
\end{aligned}
$$

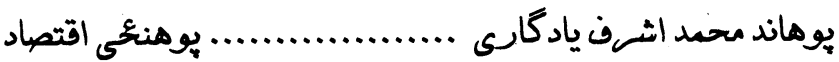

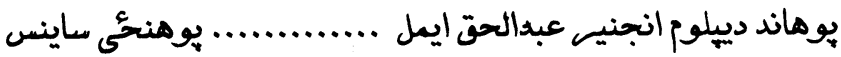

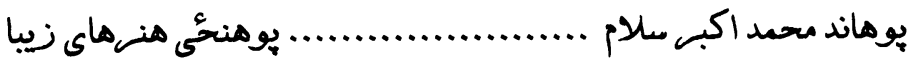

$$
\begin{aligned}
& \text { يوهاند غلام رسول صمدى .................................. يوهنى زراعت }
\end{aligned}
$$

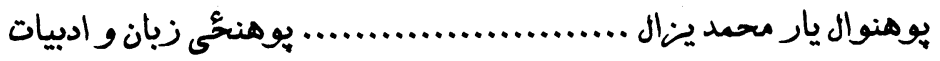

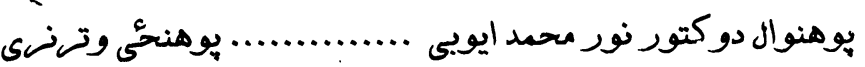

$$
\begin{aligned}
& \text { يوهنوال عبدالهسول سعيد ................................ }
\end{aligned}
$$

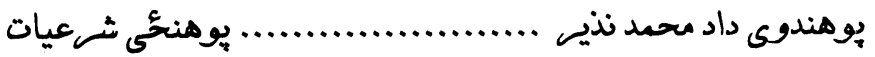

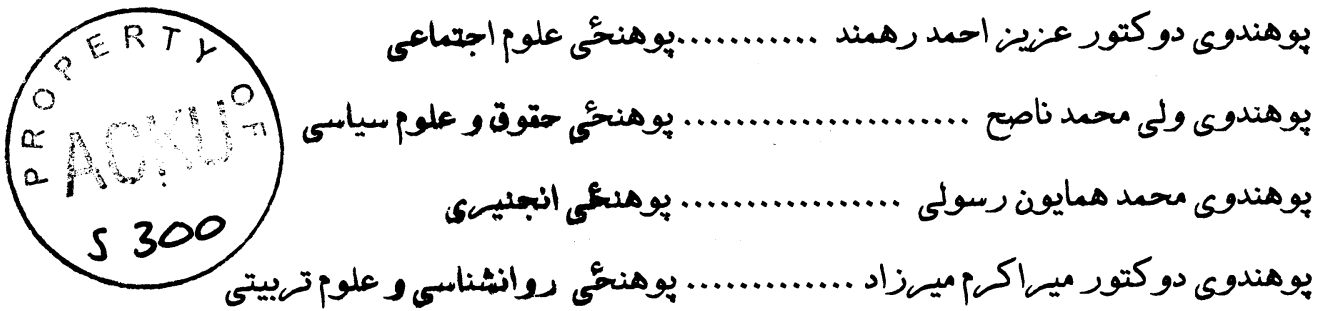

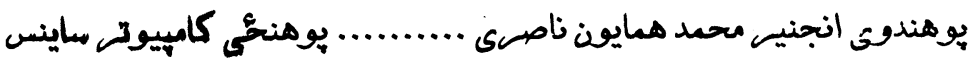




\section{فمرست مطالب:}

$$
\text { حيات و انرزى / بوهنوال عبدالسلام ماما خيل / }
$$

امكانات توسعه و انكشاف ماهى برورى در افغانستان/ بوهنوال ضيا الدين ضياً / II

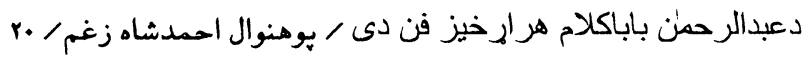

تاثير وزن بياز و فاصله كشت بالاى حاصل زعفران / بوهنوال كل احمد ظاهريان / rr

تاثير كاهش رطوبت خاك بالاى توليد مواد خشك و حاصل كندم ' بومندوى داكتر اميرجان سعيدى /rع

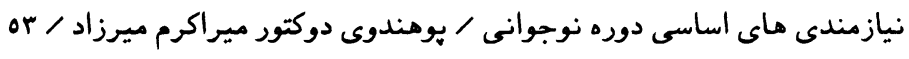

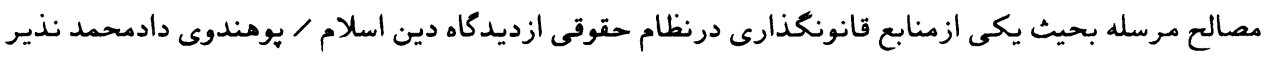
in/

د دستار نامي د اشعارو شكلي لولونو ته كره كتنه / بوهندوى محمد اجان حقبال / A

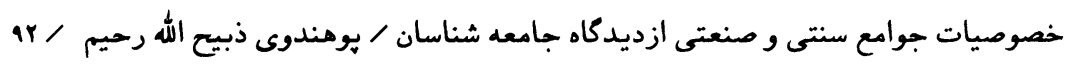
تحليل، ارزيابى واستعمال ماكروماليكولها يا (Polymers) / بوهنيار دييلوم انجنيرحبيب الله فراهى / ب. بررسى تاثيرات توكسيكولوزيك و خذه مارها / يوهنيار حفيظه حميد /.11 عقب ماندكى ذهنى دركودكان / بوهيالى سيوزمى اوريا / IMA ira / Abstracts 


\section{حيات و انرثى}

مقدمه:

آفتاب منبع مهم و اول انرجى براى حيات و زمين است و فوتوسنتيسز ميخانيكيت خاص است كه بوسيله

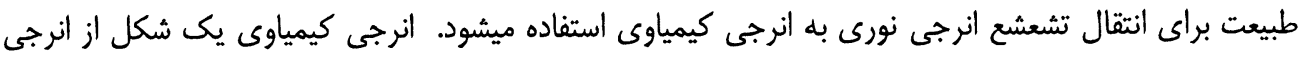

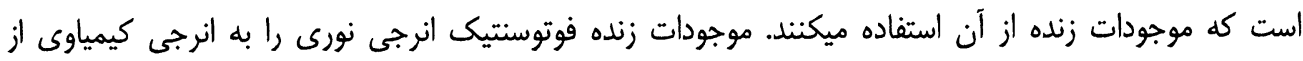

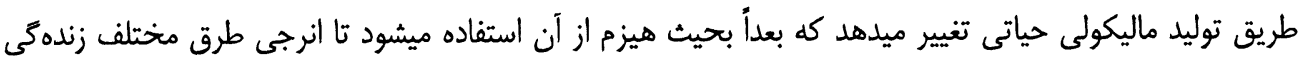

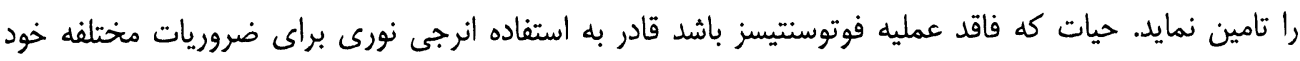

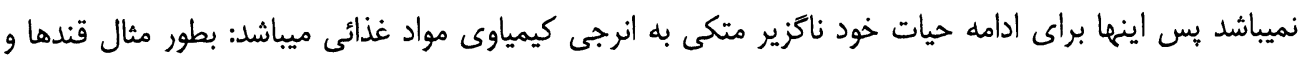
شحميات جريان بيالوزيكى انرجى را در داخل وجود موجود زنده كه شامل رهائى، تغيير و استفاده انرجى كيمياوى

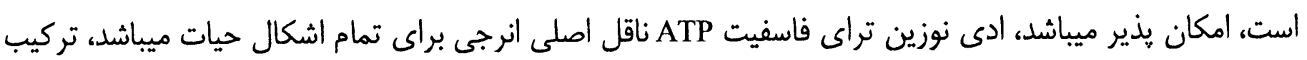

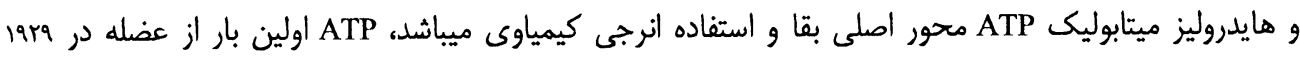

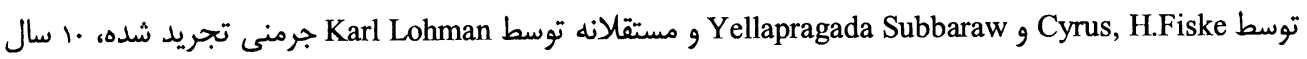

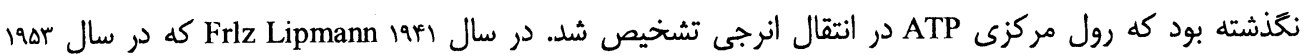

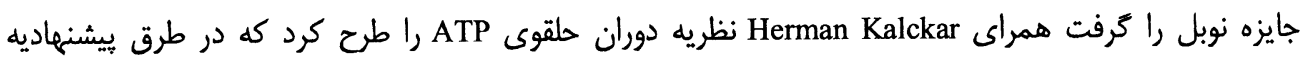

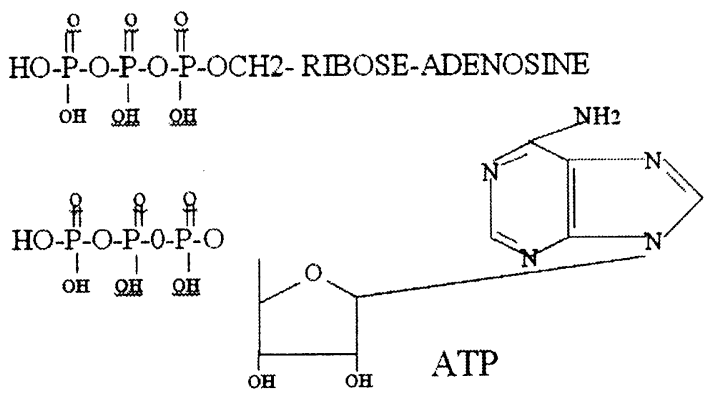
bioenergetic تغيـ انهجى آزاد يك تعامل كيمياوى: انرجى آزاد يك مركب انرجى ماليكولى همان مركب ميباشد. در تعامل AـB

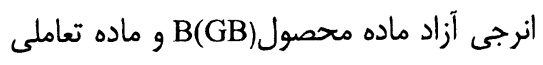
تغيير انرجى آزاد يا GA(GA) قيمت GA در محصول(B(GB ماده تعاملى ني

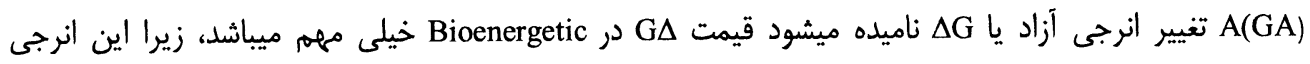

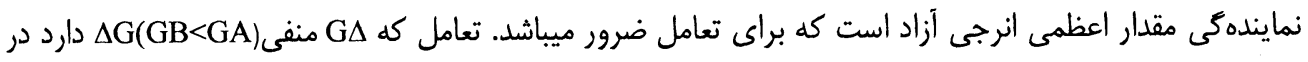

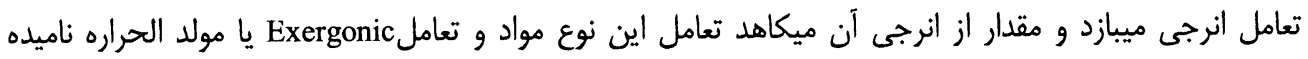

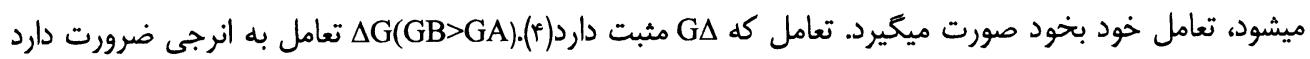

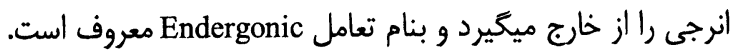


تغييسات انرجى آزاد:

فارمول محاسبه وى دG از تعامل ماده تعاملى A است كه به ماده محصول Bتغيير ميكند.

$$
\Delta G=\Delta G+R T \frac{\operatorname{Ln}[B]}{[B]}
$$

اين تعامل ارتباط به تغيير انرجى آزاد و ثابت تعادل ميخيرد. دG تغيير معيارى انرجى آزاد است كه تحت ست خاص

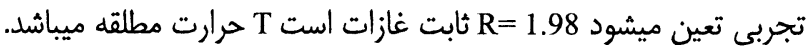
مول فىليتر است. A و تابع AG غ تغيير انرجى آزاد و غلظتهاى مواد تعاملى A و مواد

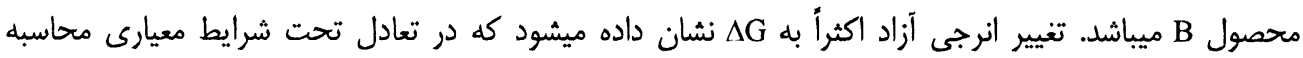

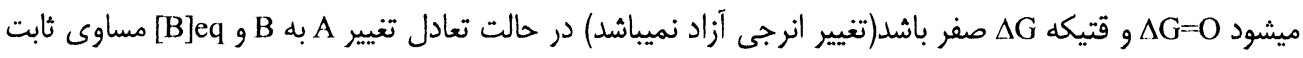
تعادل ميباشد يس معادله آن جنين تحرير ميگردد (r):

$$
\begin{gathered}
O=\Delta G+\mathrm{RT} \mathrm{Ln} \mathrm{keq} \\
\Delta G=-\mathrm{RT} \mathrm{Ln} \mathrm{keq} \\
\Delta G=2.303 \mathrm{RT} \mathrm{Log}, \mathrm{keq}
\end{gathered}
$$

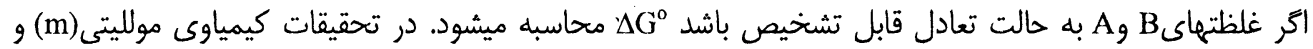

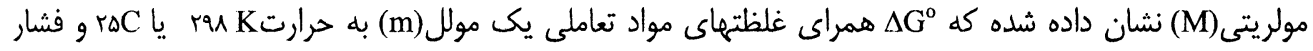
يك اتموسفير تعيين ميخردد در كيمياى حياتى فرق مولليتى و مولريتى نه شده زيادتر مولريتى استعمال ميخرد دهد.

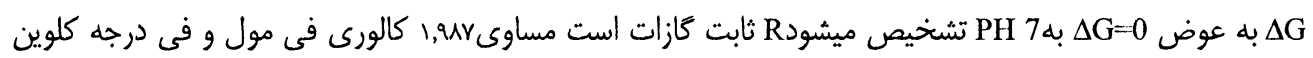
ميباشد. $\Delta G^{0}$ به كالورى فى مول حساب ميشود و از $\Delta G^{0}$ كه بd بd

$$
\begin{gathered}
\Delta G^{\circ}=-(2303)(1.987)(298) \log \mathrm{keq} \\
\Delta G=1.363 \log \mathrm{keq} \mathrm{cal} \mathrm{M}
\end{gathered}
$$

ATP

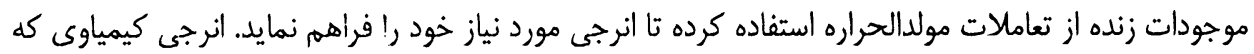

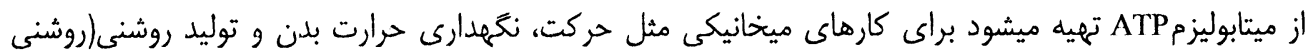

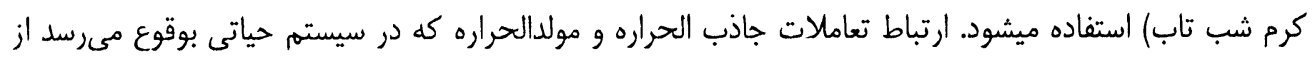

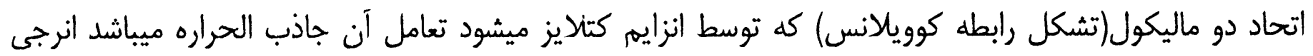

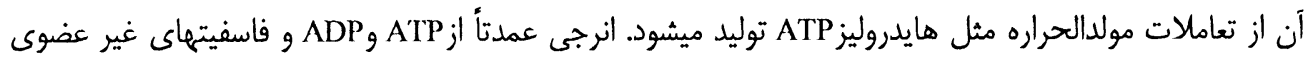

(2) حاصل ميشود) (pi) 


$$
\begin{gathered}
\text { Adenosine-ribose- } 0 \text { - } \mathrm{p}-\mathrm{O}-\mathrm{p}-\mathrm{O}-\mathrm{p}-\mathrm{OH} \\
\text { Adenine -ribose }-\mathrm{O}-\mathrm{P}-\mathrm{O}-\mathrm{P}-\mathrm{O}-\mathrm{P}-\mathrm{OH} \\
\mathrm{ATP}-\mathrm{Mg}-\mathrm{Complex}
\end{gathered}
$$

ATP and ADP

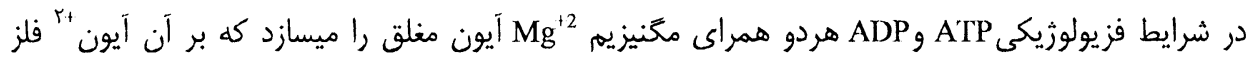

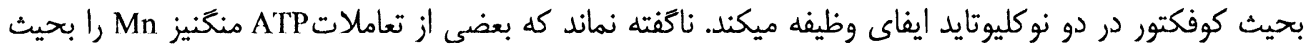

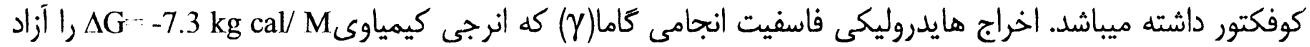

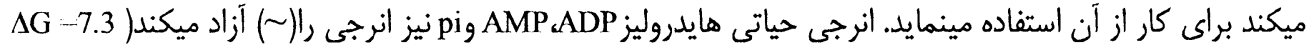

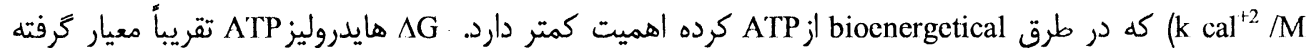

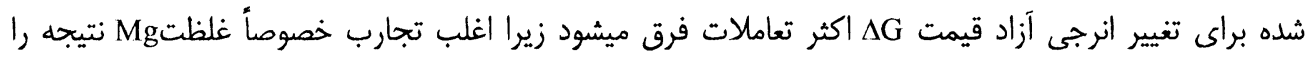

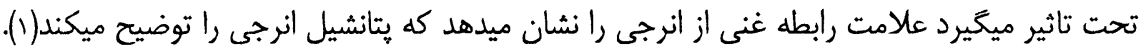

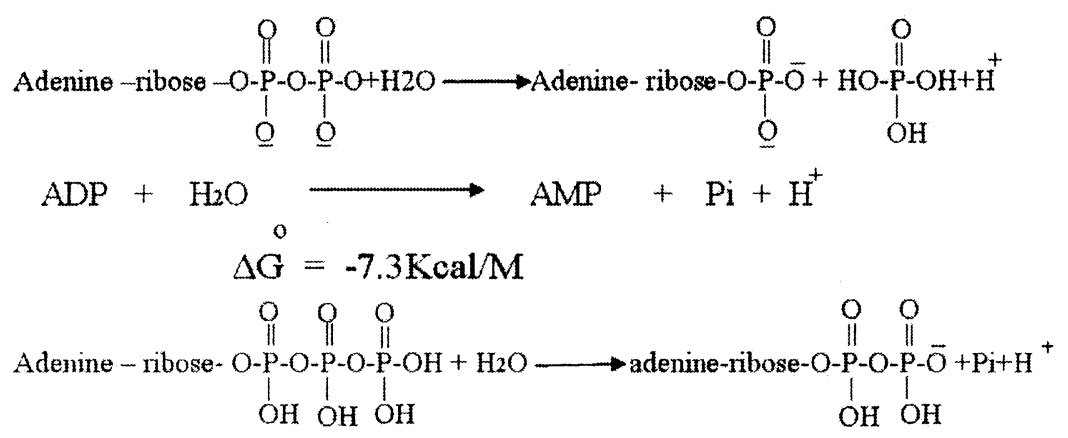

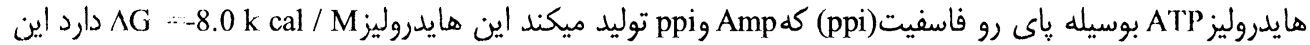
تعامل هايدروليتيكى يك ميخانيكيت خاص تعاملات متابوليكى را تكميل ميكند. زيرا هايدروليز سريع ppi محصول

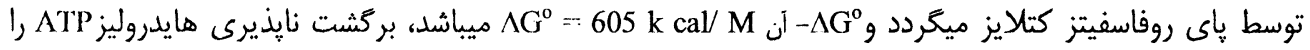




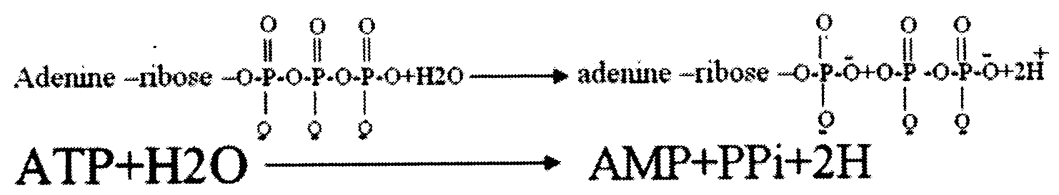

وقتيكه ATP از AMP و 2pi تركيب ميشود نياز انرجى زياد 14.5 k cal /M دارد كه اين انرجى از دو تعامل

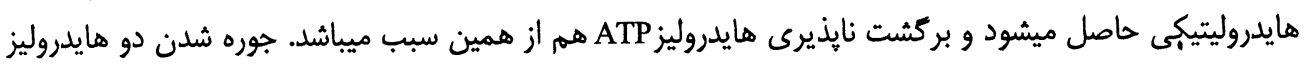

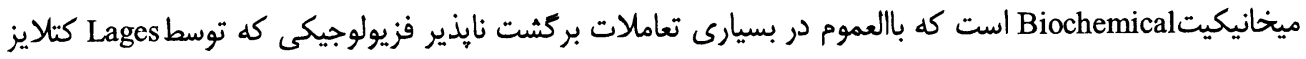
ميشوند، ميباشد. انرجى كه از هايدروليز يايروفاسفيت توليد ميشود براى كارهاى ميتابوليكى استعمال نميكردد.

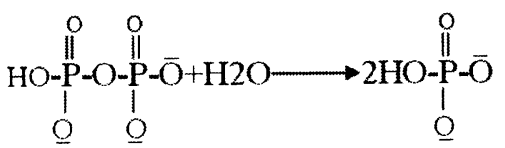

Inorganic pyrophosphate $(\mathrm{PP})+\mathrm{H} 2 \mathrm{O} \longrightarrow 2$ inorganic phosphate $(\mathrm{Pi})$

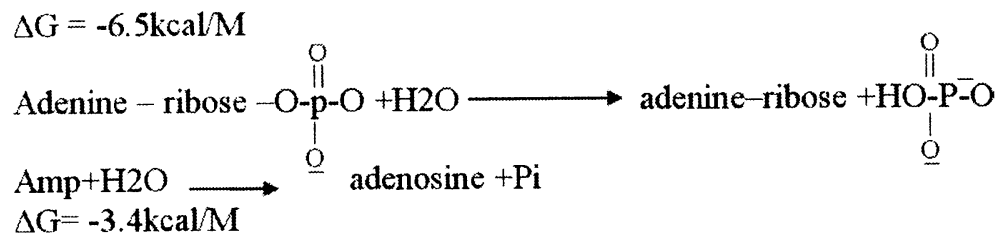

هايدروليز AMP : انرجى آزادG هايدروليز AMP به قدر كافى از انرجى آزادA ATP و ADP كمتر است 7.3 -3.4- )

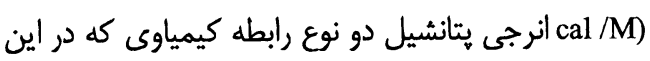

Adenine $+\mathrm{Pi}$ $\mathrm{AMP}+\mathrm{H} 2 \mathrm{O}$

$\Delta \mathrm{G}=-3.4 \mathrm{Kcal} / \mathrm{M}$

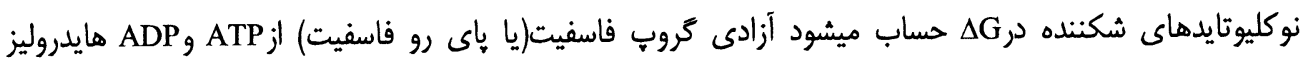

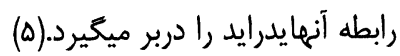
در حاليكه هايدروليزAmp رابطه استر را بين گروب هايدوكسيل كاربن ينجم(C-5) رايبوزو بقيه فاسفيت را دربر<smiles>CCC1OC2(OP(=O)([O-])O)OC1C2O</smiles> 
كه بصورت عموم انرجى زيادتر از هايدروليز رابطه استر ميباشد. طوريكه در جدول شحح شده فرق انرجى آزاد يالهاي

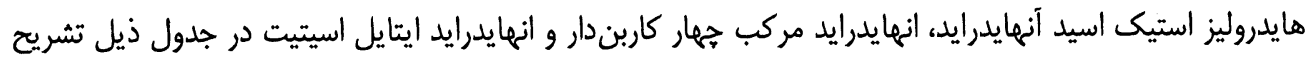

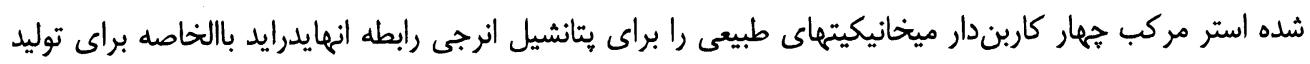
و استفاده انرجى بكار ميبرد (ع).

\section{$\mathrm{CH}_{3}-\stackrel{\mathrm{O}}{\mathrm{C}}-\mathrm{O}-\stackrel{\mathrm{O}}{\mathrm{C}}-\mathrm{CH}_{3}$}

Acetic anhydride

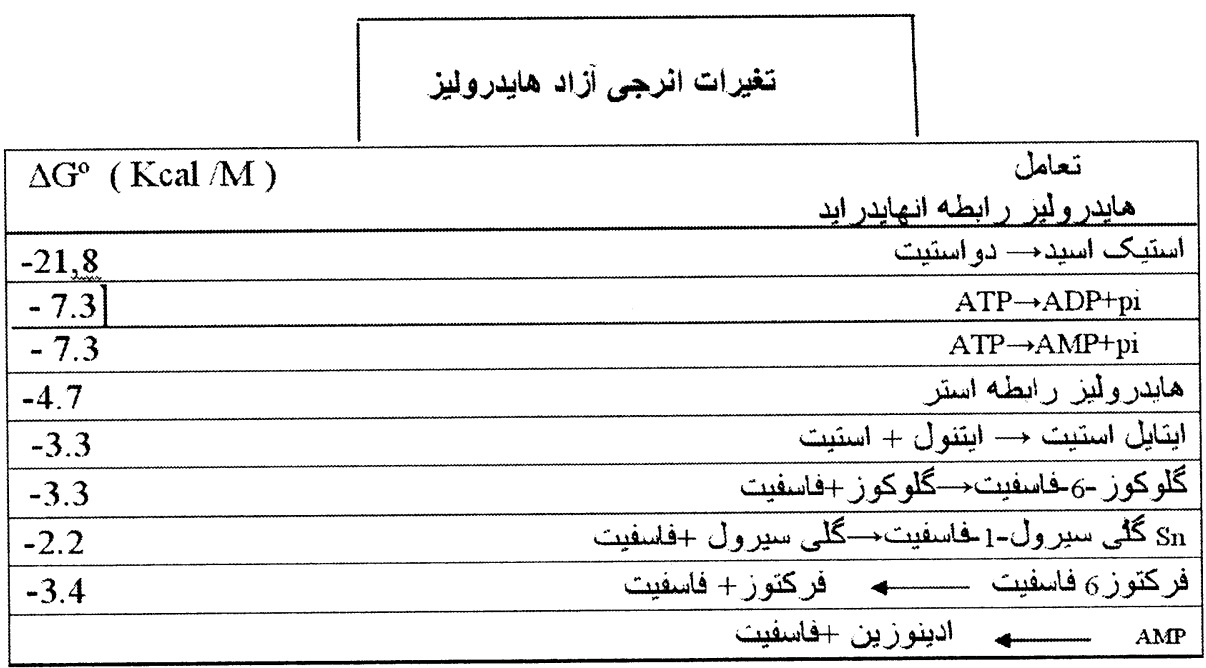

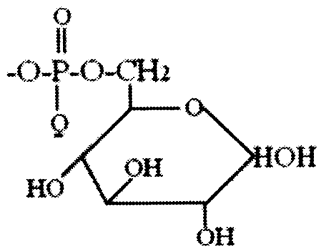

$a-D-$ gucose -6 -phasphate<smiles>O=[PH](=O)(O)CC(O)CO</smiles>

Sn-glycerol-1 phasphat
بعضى مواد كيمياوى كه كمتر انرجى توليد ميكنند.

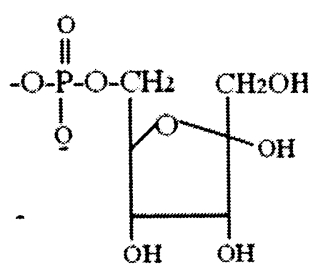

D-finctose _6-phasphate

\section{مائيكولهاى حياتى ديگ فاسفيت دار :}

بسيارى از ماليكولهاى حياتى كه فاسفيت دارند در اثر هايدروليز تغيير انرجى $\Delta G^{0}$ بزرى منفى دارند و ميتوانند انرجى

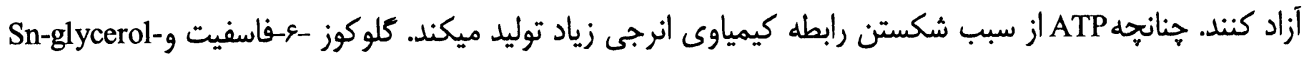


ماليكول 1-phosph ماليكولهاى حياتىاند، رابطه آن غنى از انرجى نميباشد،

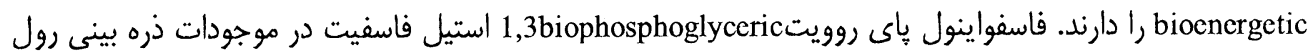
متابوليكى خوب را دارند كه حفاظت و انتقال انرجى كيمياوى را هم دربر ميتون ميكيرد . Acetyl phosphate 1,3biphosphoglyceric acid phosphocnol pyruvatc فاسفوكراياتين و فاسفوار جنين اشكال ذخيروى انرجى متابوليكىاند فاسفوكرياتين به ويزه زيادتر اهميت دارد زيرا

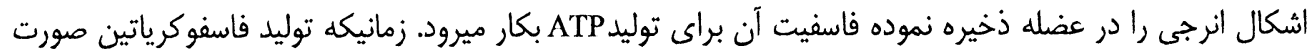

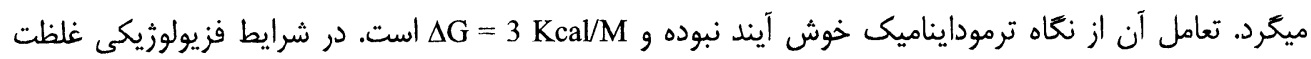

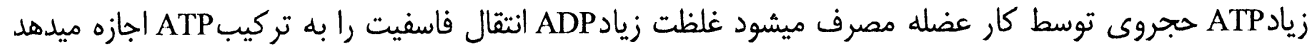

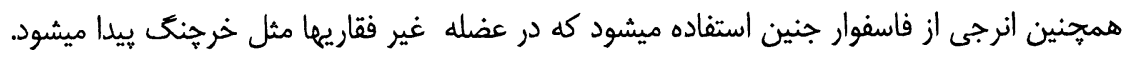
Creatine + ATP $\rightarrow$ Phosphocreatine + ADP

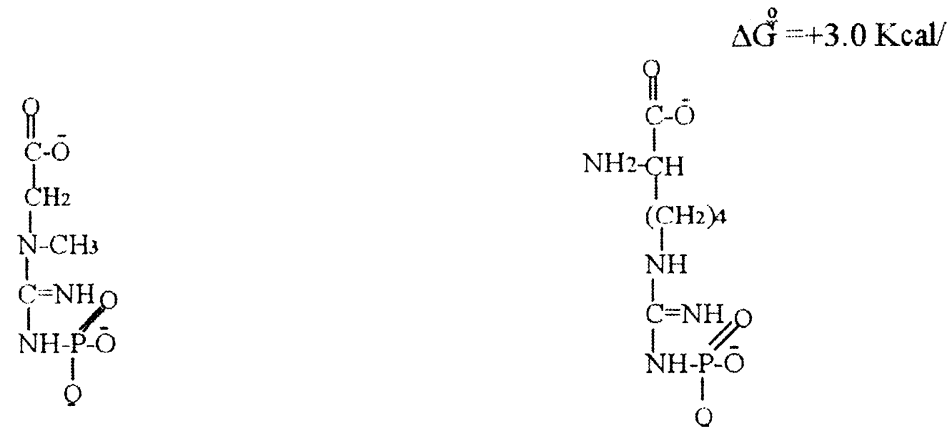

Phosphocreatine

phosphoarginine

تعاملات هايدروليتيكى 1 خيلى منفى را توليد ميكند. تغيير انرجى آزاد خيلى منفى توام با هايدروليز بايوماليكولهاى فاسفيتدار كه انرجى بلند دارند، ميباشد كه تعيين

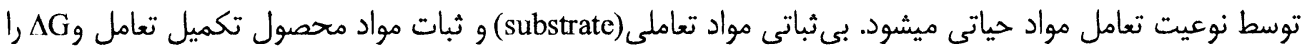

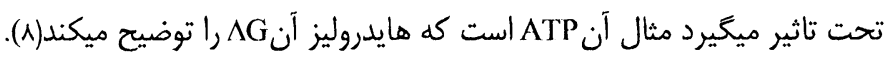
Adenine ribose - O-P-O-P-O-P-O

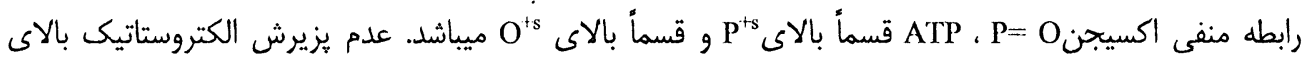

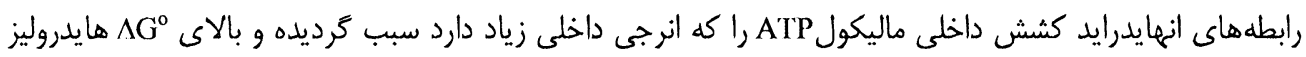

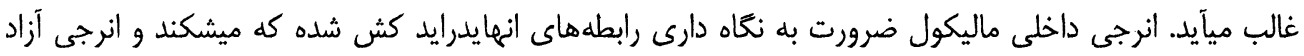




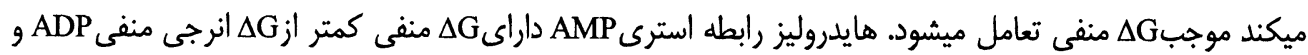
ميباشد زيرا درينجا عدم پذيرش الكتروستاتيك توام با شكستن رابطه است.

$$
\text { Adenine - ribose -O-P-O-P-O-P-O }
$$

در هايدروليز رابطه استيل فاسفيت مواد تعاملى و مواد محصول هر دو سبب توليد 00

مىباشند. در هايدروليز مختلط رابطه انهايدرايد (-C-O-P-P) و ايونايزيشن محصول استيك اسيد كه از نكاه ترموداينا ميك خيلى مهم ميباشد كروب غير هايدروليز PKa 4.7)-CooH) استيك اسيد است و محصول اولى هيلى هايدروليز بودها فوراً به7 PH ايونايز ميشود.

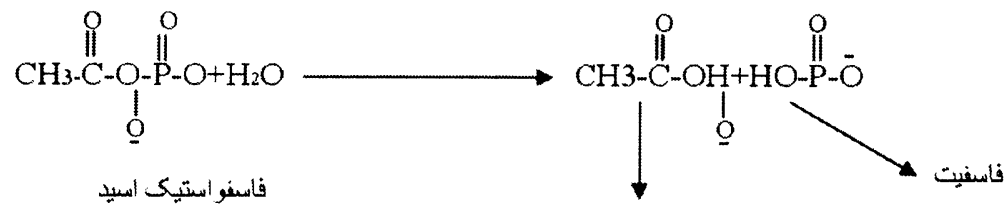

Acetic acid (initial product)<smiles>C=C(C(=O)[O-])P(=O)(O)O[18O]</smiles>

Phosphoenal pyruvate

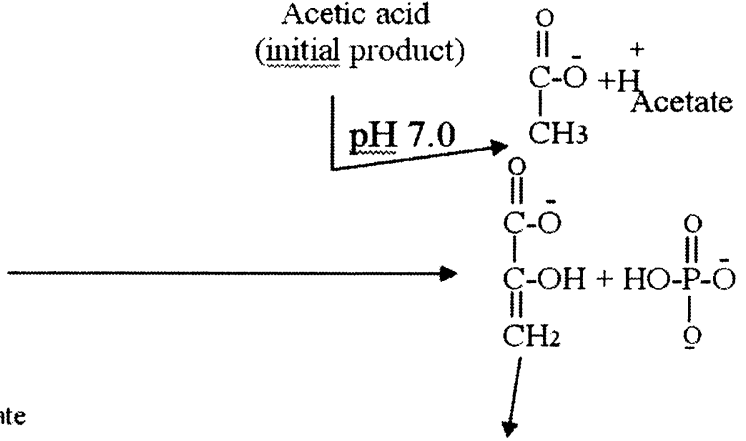

Pyruvate enol form(enitial product)

ايونايزيشن موثرانه، هايدروليز را توسط تقليل متداوم غلظت محصول تعامل اولى بطرف تكامل ميبرد. در اينجا فرق

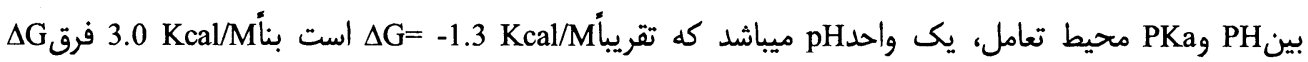

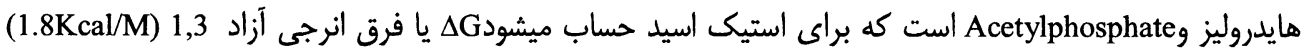
است و مساوى بهd ايونايزيشن محصول biphosphogyceric در مورد phosphoenolpyravate (كه ميباشد). بايرويت فوراً به شكل ثابت كيتوتوتومرايز

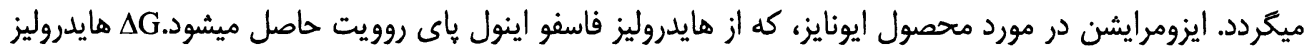

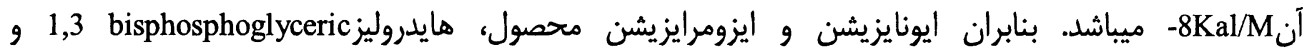

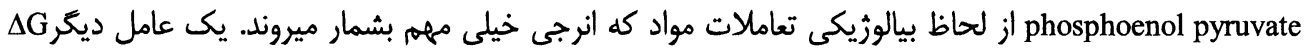


منفى هايدروليز ثبات مواد محصول توسط ريزونينس ميباشد ثبات محصول به انواع ريزونتس ممكن است. وقتيكه

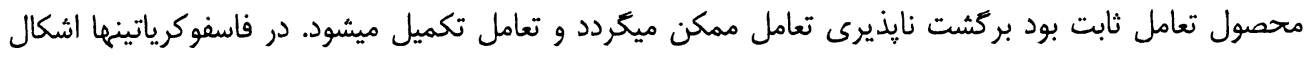

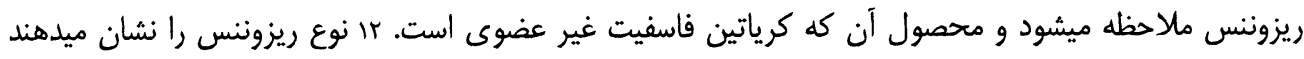

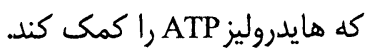

$$
\text { تركيب نوكليوسايد تراى فاسفيت: }
$$

درجريان ميتابوليزم ATP عامل بارز انرجى دهنده كيمياوى ميباشد. ديكر نوكليوسايدهاى تراى فاسفيت نيز بحيث

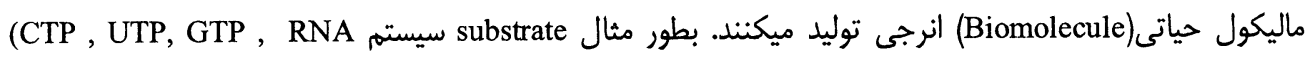

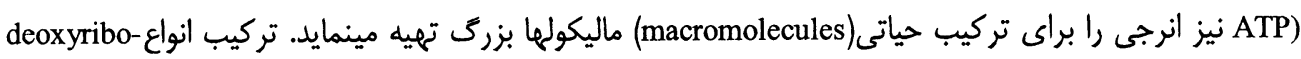

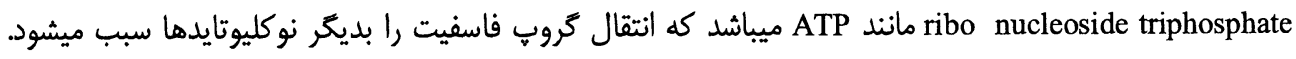

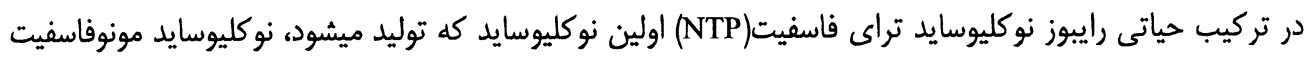

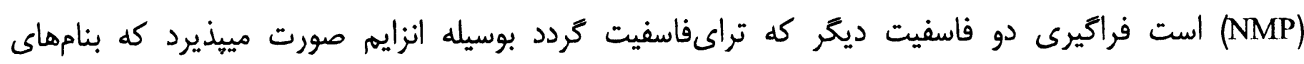
monophosphate kinase , nucleoside diphosphat kinase Transferase

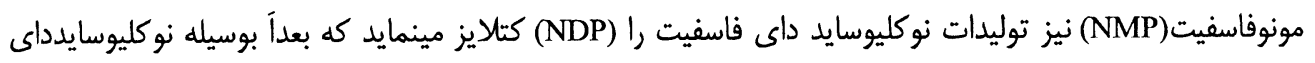

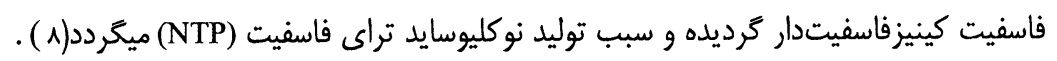

Nucleoside monophosphate kinase $(\mathrm{NMP})+\mathrm{ATP} \longrightarrow \mathrm{NDP}+\mathrm{ADP}$

Nucleoside diphosphate kinase $(\mathrm{NDP})+\mathrm{ATP} \rightleftarrows \mathrm{NTP}+\mathrm{ADP}$

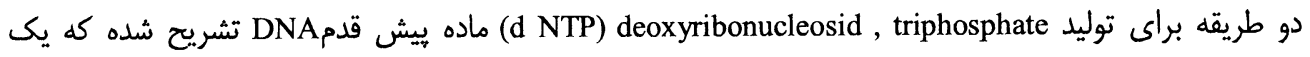

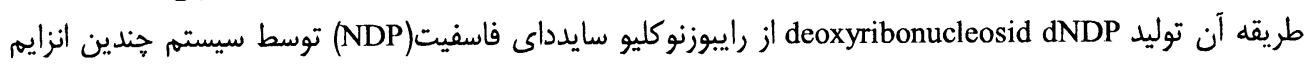

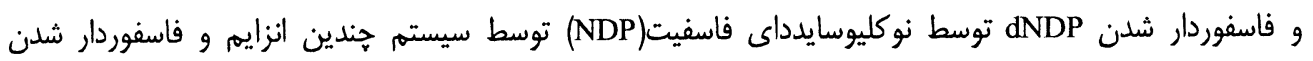

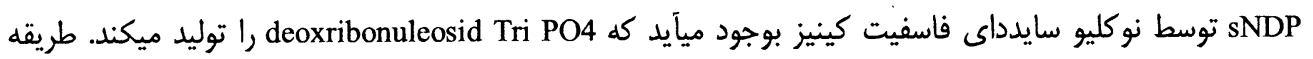

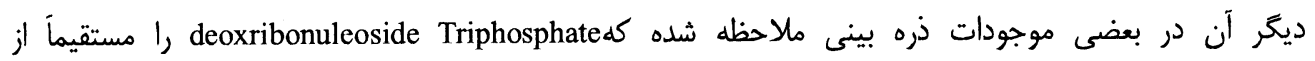
ribonucleoside triphsphate

Multenzyme ststem NDP $\longrightarrow$ dNDP

Nuckoside diphosphate kimase $A T P$ dNDP

Some microorganisms MTP $\rightarrow$ dNTP

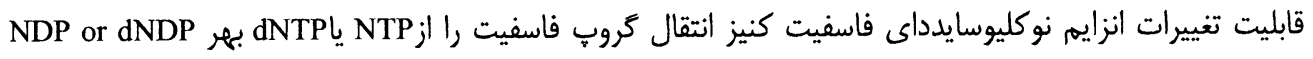

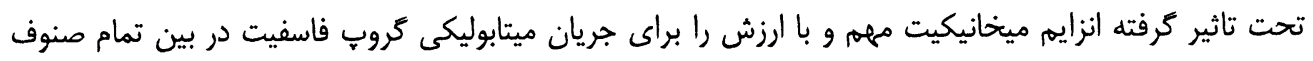


نوكليوسايد بالخاصه داىوتراى فاسفيت تهيه مينمايد، تعاملات كه توسط نوكليوسايدداى فاسفيت كنيز كتلايز

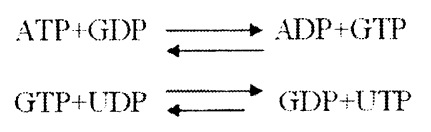

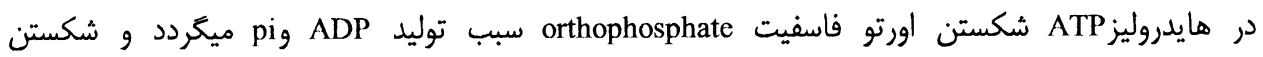

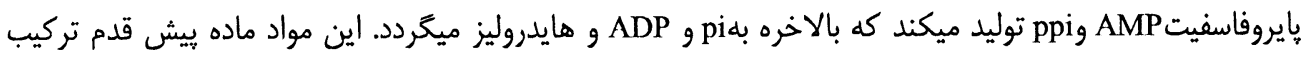

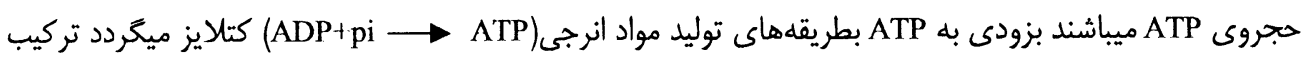

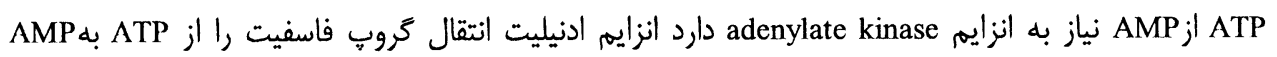

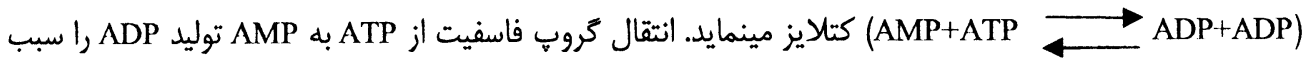

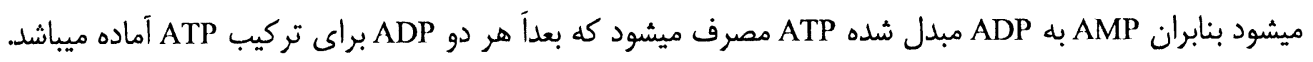

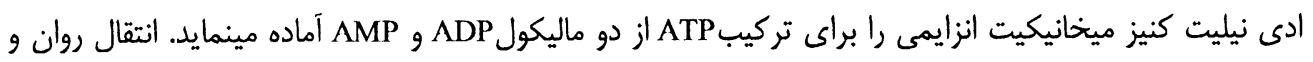

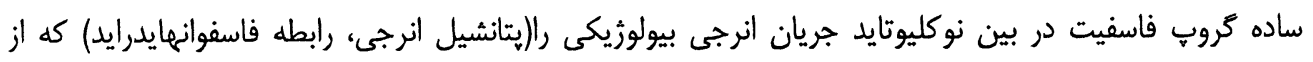

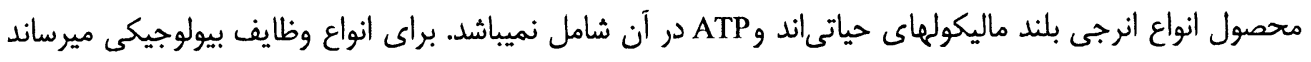

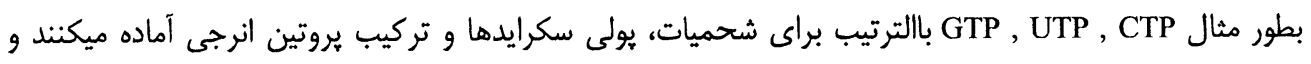

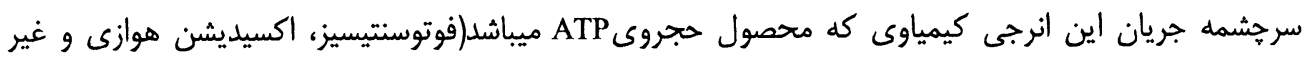

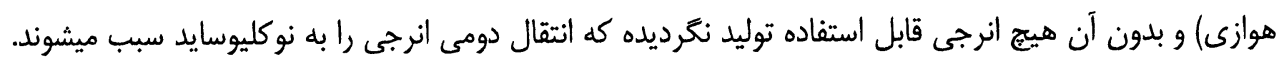
نتيجدكيهى:

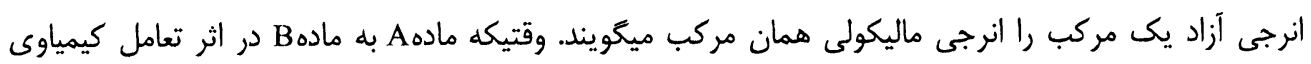

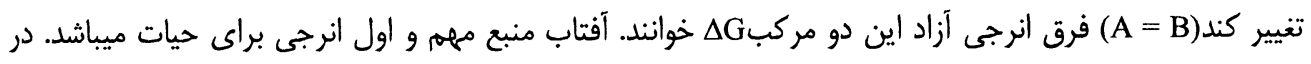

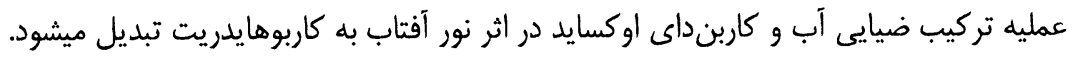
$6 \mathrm{CO}_{2}+6 \mathrm{H}_{2} \mathrm{O} \rightarrow \mathrm{C}_{6} \mathrm{H}_{12} \mathrm{O}_{6}+6 \mathrm{O}_{2}$

$\Delta \mathrm{G}=+673 \mathrm{Kcal}$

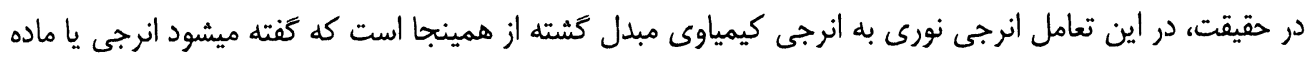

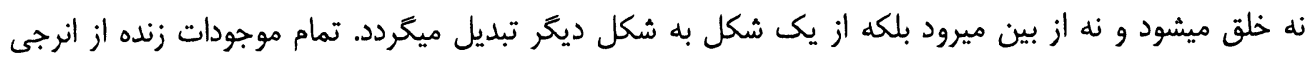


كيمياوى استفاده به عمل ميأورد. حيات كه فاقد قابليت وقوع تركيب ضيايى باشد، قادر به استفاده نور آفتاب

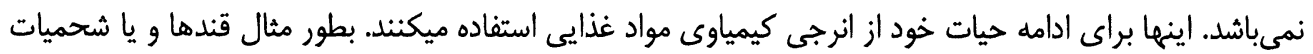

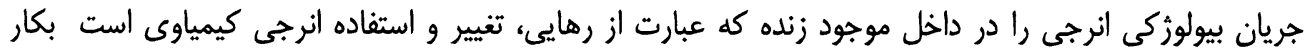

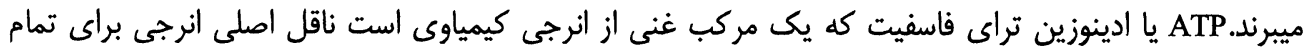

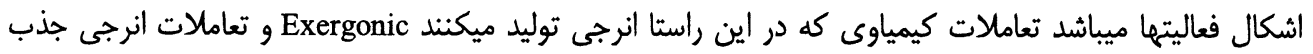

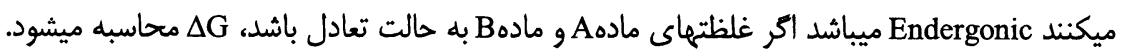
$\Delta \mathrm{G}=-\mathrm{RT} \operatorname{Ln} \mathrm{K}_{\text {eq }} \quad \Delta \mathrm{G}=-(2.303) \mathrm{RT} \log _{10}$

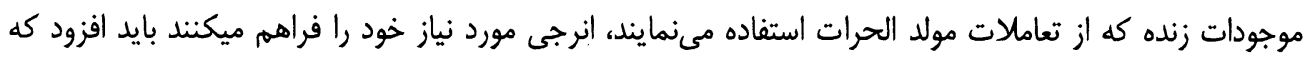

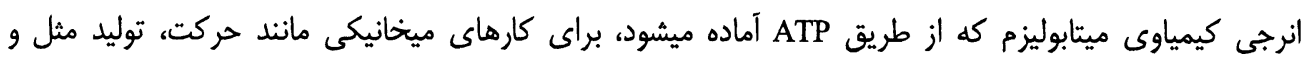
نكهدارى حرارت بدن استفاده ميشود(1).

\section{References:}

1. Backer, E . 1976.Anew look at mechanisms in bioenergetics New York Acadomi press.

2. Bull Henry B. PhD 1989 physiocal biochemistry F.A. Davis company pp 54 ,212,213.

3. Handler Philip $\mathrm{PhD}$ and Abraham white $\mathrm{PhD}$ and Robert L. Hill،1983 prinsipels of biochemistry $7^{\text {th }}$.ed $. M c G r a w-$ Hill book company new York st. Louis pp 441-445.

4. Haper Harold $\mathrm{A}$. $\mathrm{PhD}$,Pater mayes $\mathrm{A} \mathrm{PhD}$.(2001) review of physioloyical chemistry $30^{\text {th }}$ lange medical puplication pp 218 / 224.

5. Hood 1998Biochemistry - A problems Approach $2^{\text {nd }}$ ed Menlo park ,calif,BenJami cummi ,ngo.

6. Racker, E., A 1976new look at mechanisms in Bioenergetics 1986 New York, Academic press.

7. Segel i.H.1996 Biochemical calculation $2^{\text {nd }}$ ed . New york Villy.

8. Stumpf P.K. ATP scientific American 188(4):85,1976. 


\section{امكانات توسعه و انكشاف ماهى يرورى در افغانستان}

محاط بودن افغانستان به خشكه باعث شده تا از صنعت ماهى

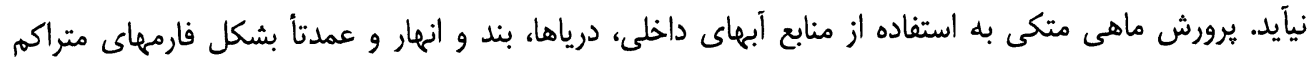

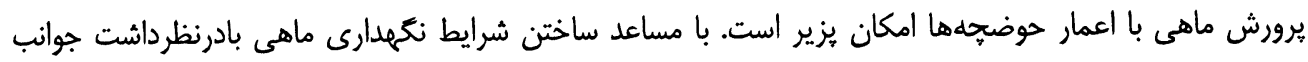

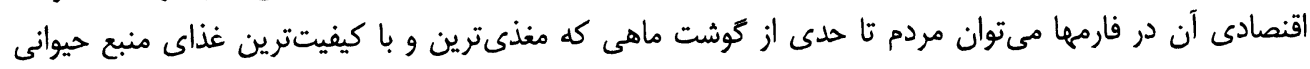

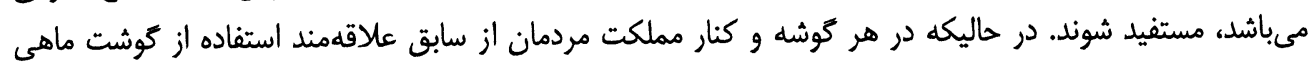

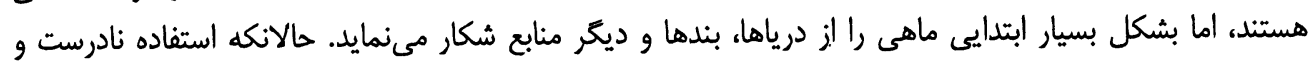

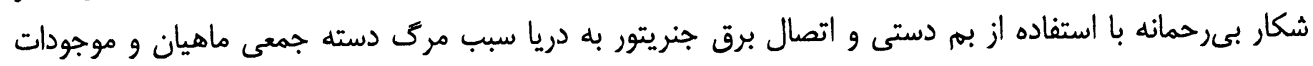

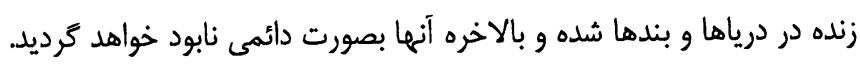

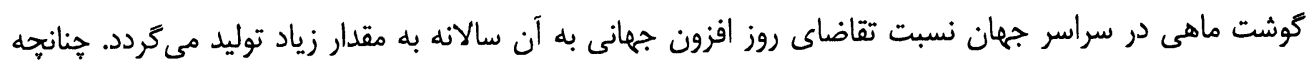
برداشت ماهى درسال 2005 در جهان به 141 ميليون تن رسيده است. در حال حاضر ماهر ماهى طور اوسط

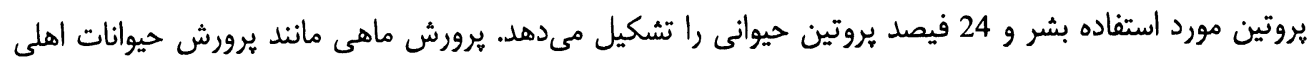

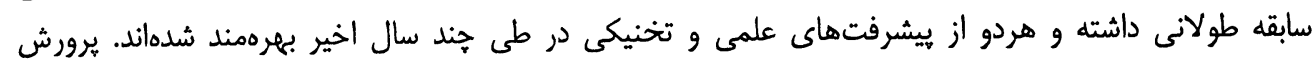

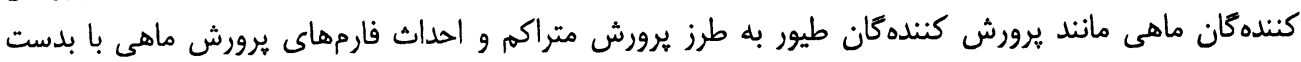

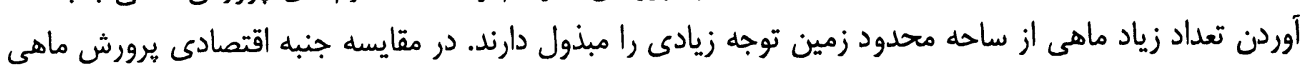

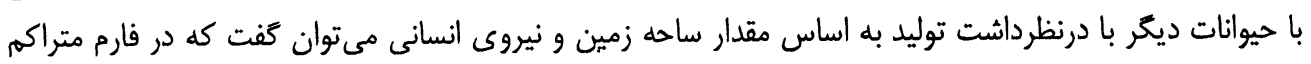

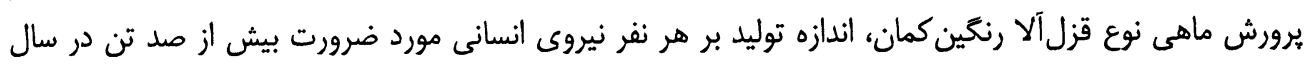

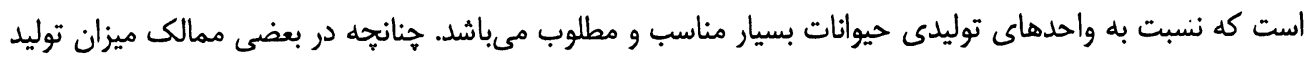

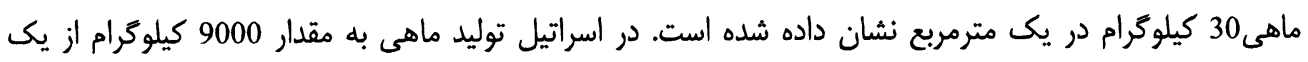

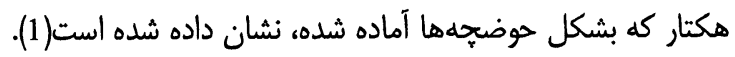

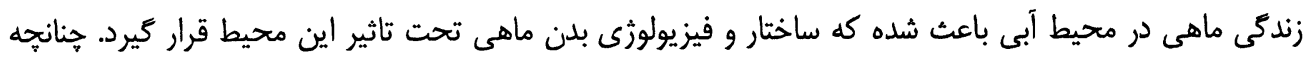

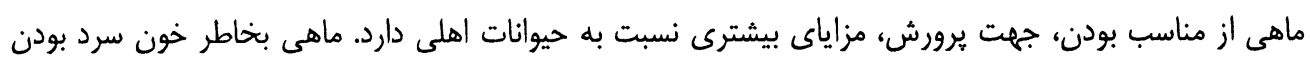

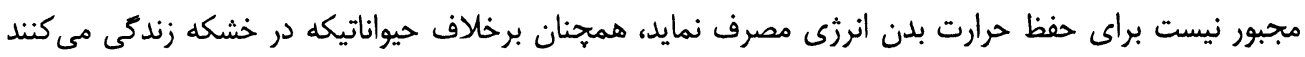

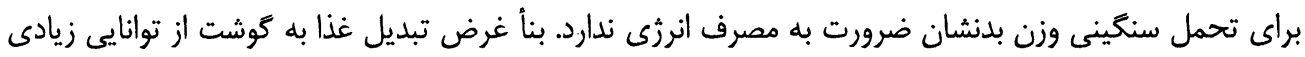

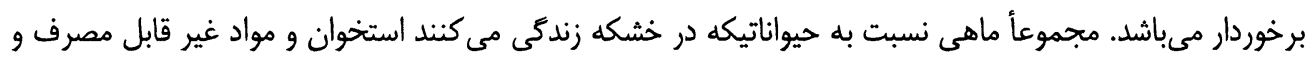


زايد كمتر دارد. برعلاوه بحيث يك منبع غذايى نسبت به كوشت مرغ و كوشت قرمز ازت از نظر سلامت جسمى انسان

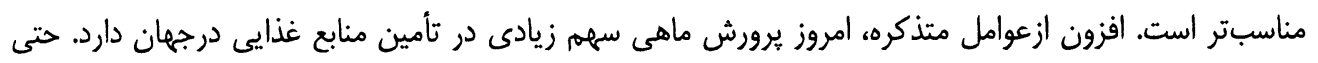

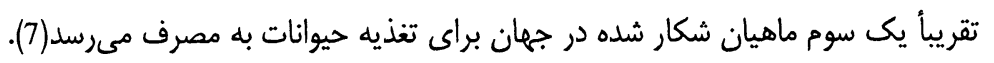

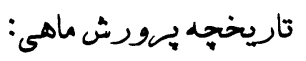

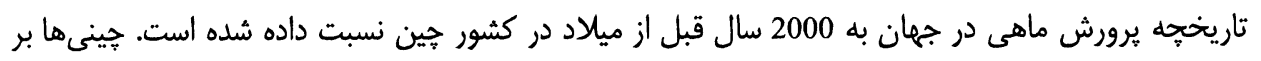

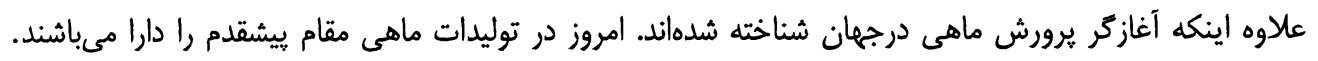

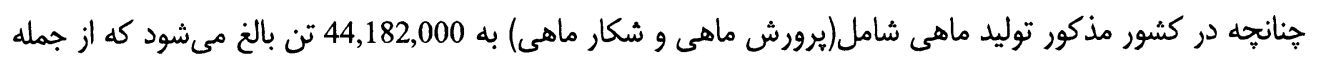

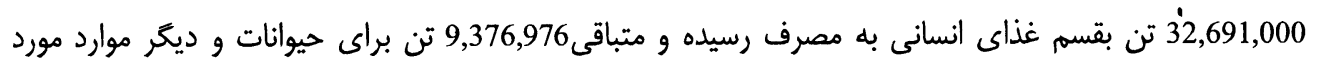

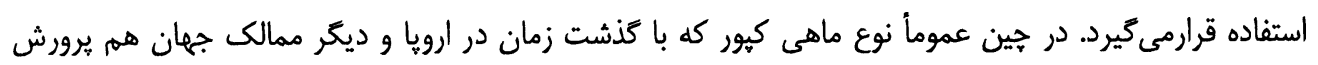

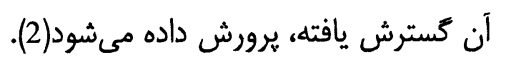

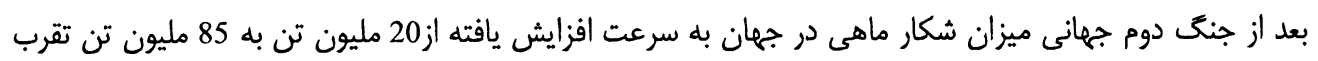

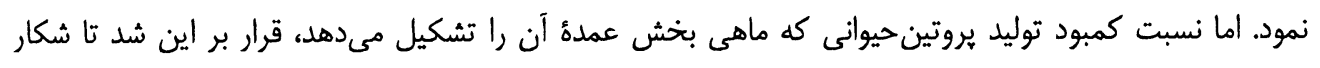

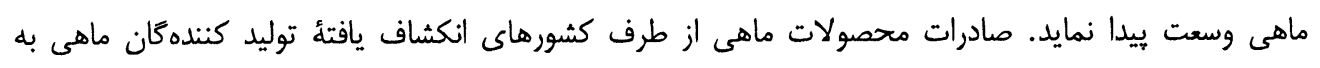

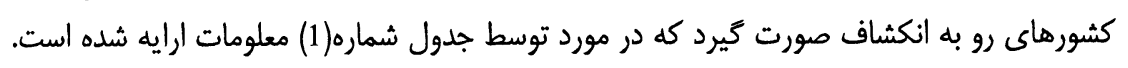
جدول(1): توليدماهى در جهان، ممالك انكشاف يافته و روبه انكشاف با فيصدى مصارف انسانى و غيره مصارفات

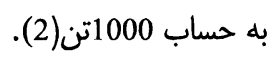

\begin{tabular}{|c|c|c|c|c|c|c|c|}
\hline 2005 & 2004 & 2003 & 2002 & 2001 & 2000 & 1997 & ماهى \\
\hline 141.403 & 140.288 & 133.036 & 133.587 & 131.001 & $131: 087$ & 122.817 & جهان \\
\hline 108.609 & 105.631 & 100.289 & 100.516 & 100.177 & 97.037 & 91.832 & الستفاده \\
\hline 33.394 & 34.657 & 29.794 & 30.070 & 30.824 & 34.050 & 30.985 & ديكر \\
\hline 76.4 & 75.3 & 77.6 & 75.2 & 76.5 & 74,0 & 74,8 & 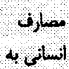 \\
\hline 23,6 & 24,7 & 22,4 & 24,8 & 23,5 & 26,0 & 25,2 & ديكر به \\
\hline
\end{tabular}




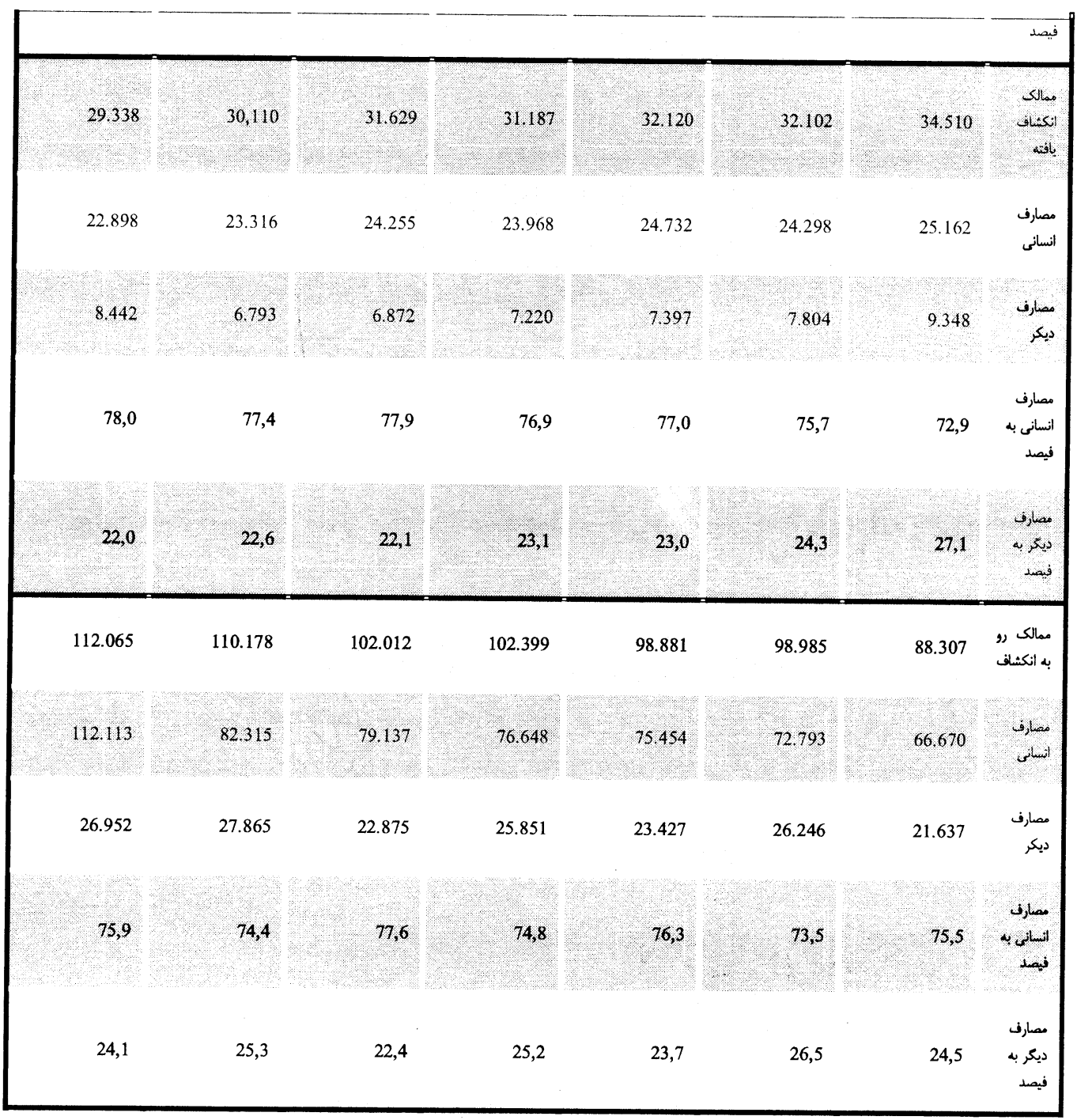

در افغانستان، در سال 1342بندقرغه به هدف يرورش ماهى نوع قزلآلا به كمى كشور بلغاريا تحت نظر متخصين

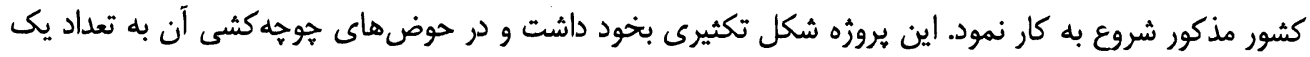

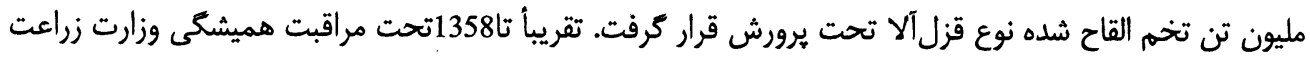

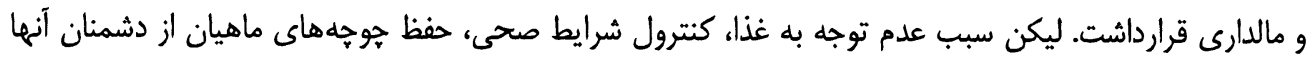

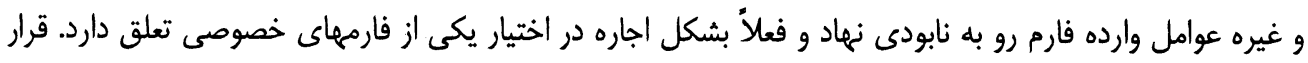

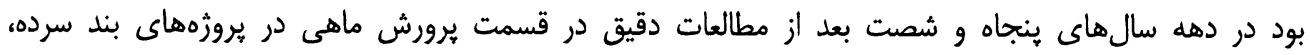


بندغازى و بندسلطان و بندخروار و غيره بندها يرورش ماهى صورت گيرد اما ظهور شرايط جنگى در دهلهاى

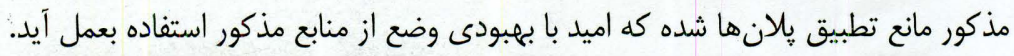
در سال1345 يرورش تكثيرى يرورش ماهى در بند درونته به كمك حكومت مردم جين اعمار شد. در اين يروزه

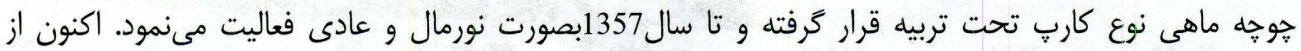

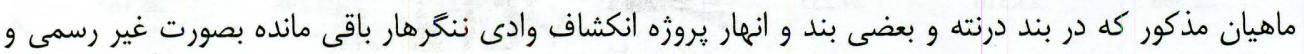

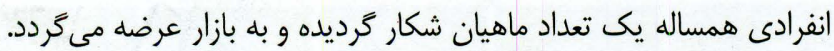
كاركردهاى دفتـ همكارى هاى دولت فر انسه در رابطه بـهورش ماهى:

به سلسله بازسازى و احياى مجدد زراعت و مالدارى كشور، دفتر همكارىهاى دولت فرانسه براى وزارت زراعت و مالدارى، در يهلوى ساير بخشهاى زراعت و مالدارى اقدام سودمندى در قسمت بازسازى و انكشاف ماهى ماهى

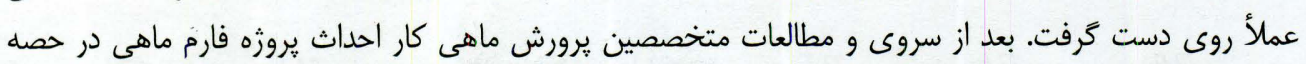

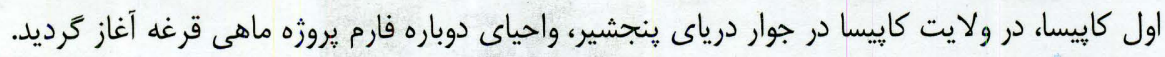

يكى از اهداف عمده در مورد اعمار و بازسازى هردو فارم، تكثير و ترويج نثاد ماهيان درخود فارمها، درياها، بندها،

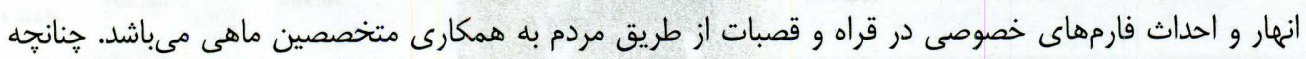
درسه مرحله وارد نمودن

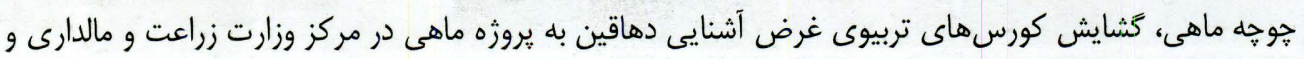

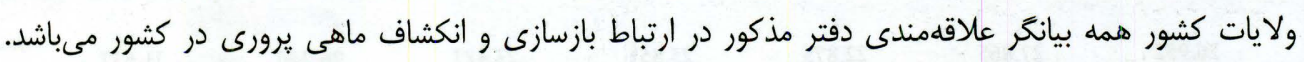

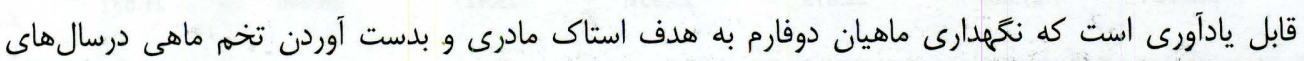

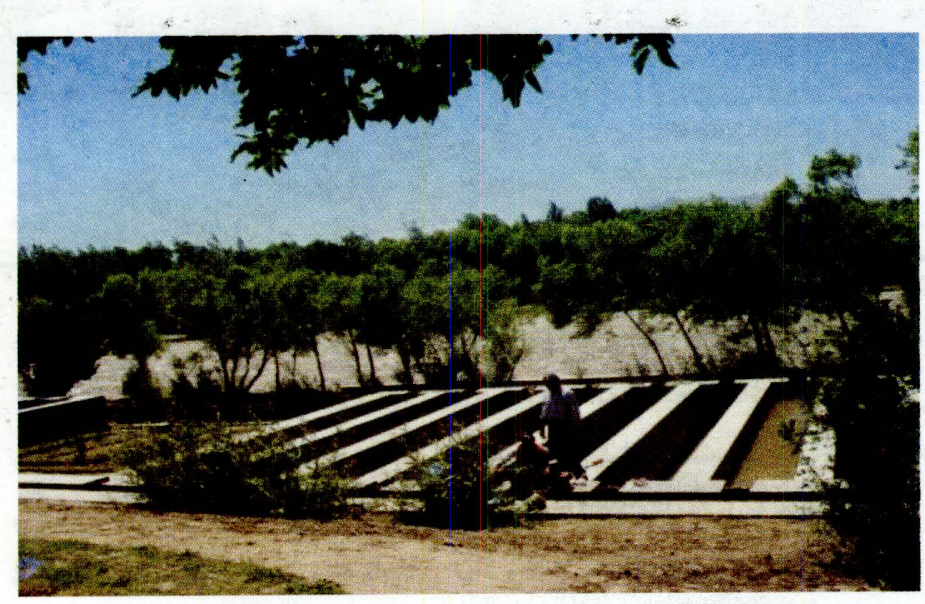

آينده وانمود شده است(4).

شكل (1) نمايیى از فارم ماهى كاييسا در جوار درياى ينجشير (4). 

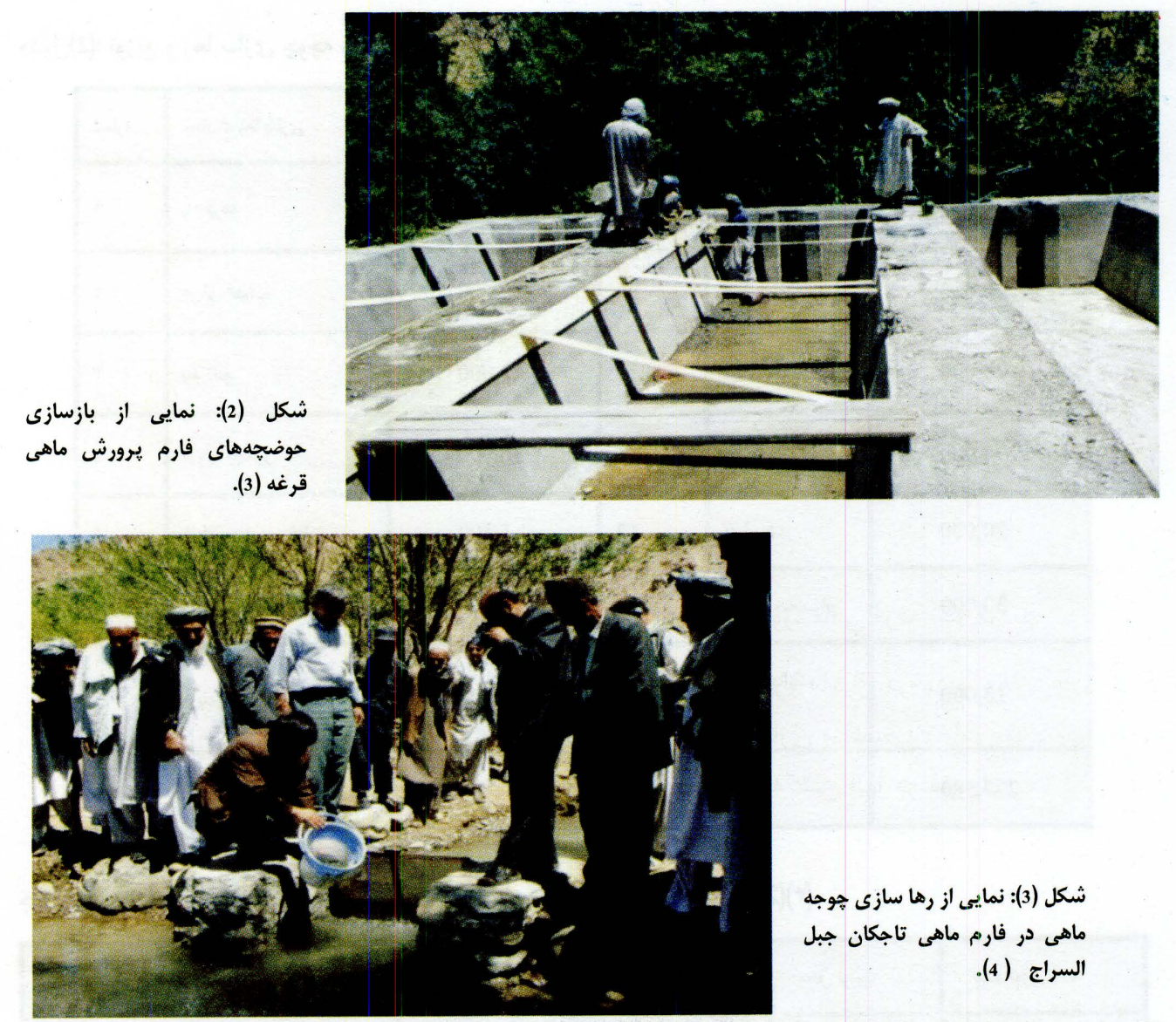

شكل (3): نمايى از رها سازى هوجه

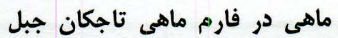
السراج (4).

شكل (4): نمايى از رها سازى هوجه

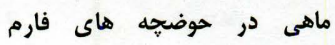
يرورش ماهى كايِيسا (3).

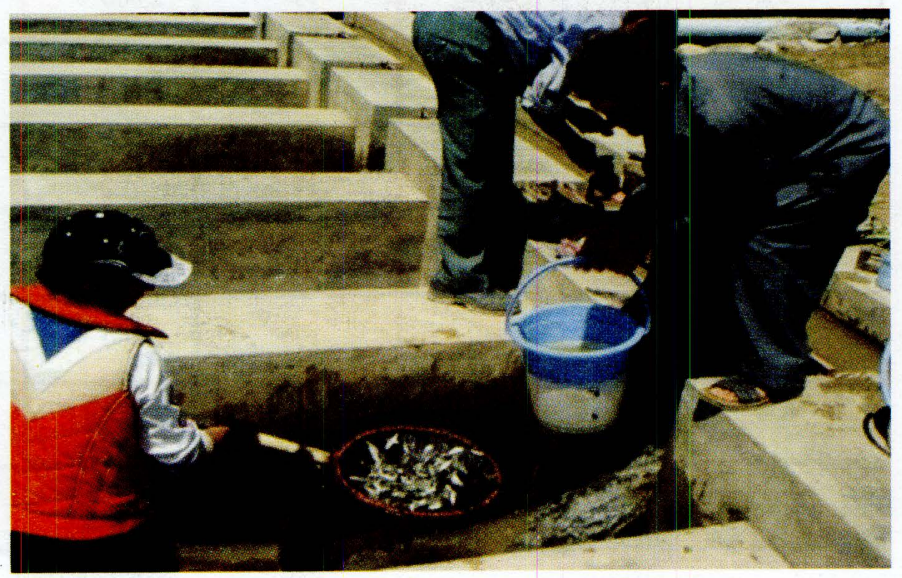


جدول(2): توزيع و رها سازى جوجه ماهى در درياها و بندها در محلات مختلف كشور در سالهاى (2007و2008)(†).

\begin{tabular}{|c|c|c|c|c|c|}
\hline تعداد بوجه ماهى رهاشده & 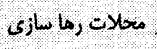 & نماره & تعداد جوجه ماهى رهاثده. & مانات رها ساز & شماره \\
\hline 40,000 & رئياى يخمان & 8 & 62,000 & بند قرعه & 1 \\
\hline 10,000 & رياي بغلان & 9 & 10,000 & درياى انثراب & r \\
\hline 20,000 & درياى كلبهار & 10 & 13,000 & بند نتلو & $r$ \\
\hline 5,000 & رياى كنر & 11 & 30,000 & درياى نجثير & P \\
\hline 20,000 & رياى شتل & 12 & 1,500 & رياى جاغورى غزنى & a \\
\hline 30,000 & بنديرق جبالاسراج & 12 & 20,000 & رباى ساتكى جنوبى & ? \\
\hline 13,000 & 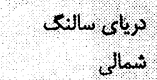 & 14 & 3,000 & رياك جغ لوكر & v \\
\hline 277,500 & & & & & مجموع \\
\hline
\end{tabular}

جلول(3): توزيع جوجه ماهى به فارمهاى خصوصى در سالهاى (2007و2008)(†).

\begin{tabular}{|c|c|c|c|c|c|}
\hline تعداد توزيع شده. & محل توزيع & ( ) & تصداد توزيع شنده. & محل توزي & شماره \\
\hline 3,000 & فارم سرى يل & 13 & 2,000 & فارم كليهار يروان & 1 \\
\hline 1,000 & كارم كابل & 14 & 2,100 & فارم كايسا & 2 \\
\hline 3,500 & كارم بغالان & 15 & 17,500 & فارم جبل أسراج يروان & 3 \\
\hline 2,500 & B & 16 & 15,000 & فارم دوراهى بكرام & 4 \\
\hline 1,500 & فارم بنجشير & 17 & 2,000 & فارم مياد كاييسا & 5 \\
\hline 1,200 & فارم يووان & 18 & 3,000 & كازم تخار & 6 \\
\hline 12,500 & فارم كاييسا & 19 & 2,500 & فارم تخار & 7 \\
\hline
\end{tabular}




\begin{tabular}{|c|c|c|c|c|c|}
\hline 10,000 & فارم يروان & 20 & 2,500 & فارم تخار & 8 \\
\hline 2,500 & فازم يروان & 21 & 2,100 & فارم تخار & 9 \\
\hline 10,000 & قارم باميان & 22 & 2,500 & فازم نخار & 10 \\
\hline 5,000 & فارم بنالان & 23 & 2,300 & فارم تخار & 11 \\
\hline 3,000 & فارم يغمان & 24 & 2,000 & فارم جوزجان & 12 \\
\hline \multicolumn{5}{|c|}{111,200} & \\
\hline
\end{tabular}

تخهم توليدى ماهى بعد از طى مراحل(تخمريزى، بارورى تخمها، جشمه زدن تخمها، رشد لاروا و رشد جوجه ماهى

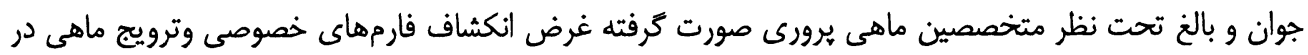

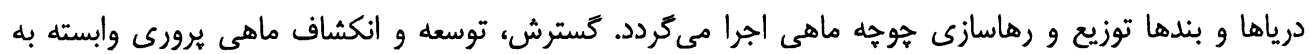

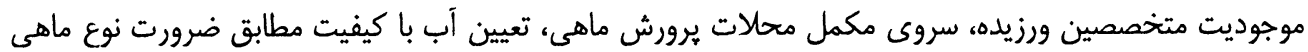

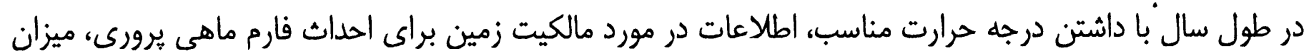

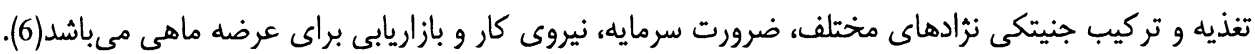
اين يك امرى واضح است كه بدون آشنايى و اطلاعات راجع به زيست شناسى ماهى، ساختمان و فعاليت اعضاى

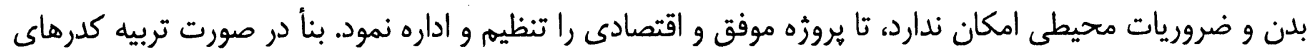

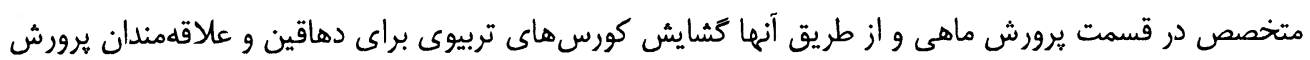

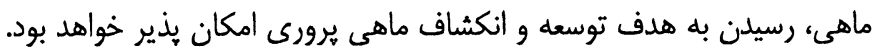
در افغانستان نتايج مطلوب از يرورش ماهىهاى سرد آبى نوع قزل آلاى رنگين كمان و نوع ماهى گرم آبى بدست

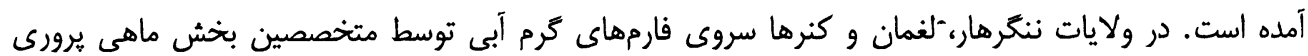

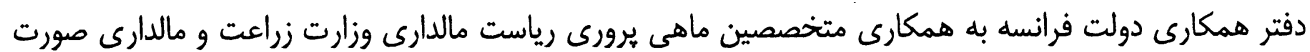

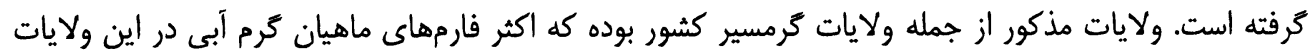

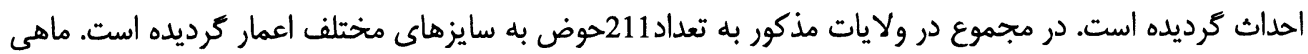

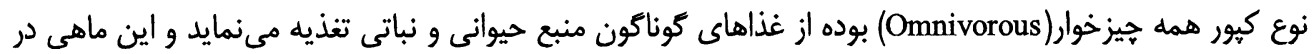

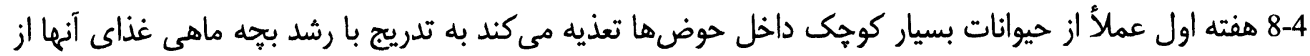

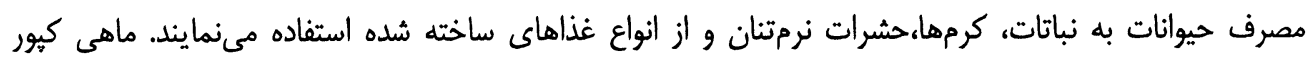
معمولأ از خوردن فضلات حيوانى و نباتى حتى از لاشه حيوانات تغذيه مى كنند. متخصصين جنتيك توانستهاند از

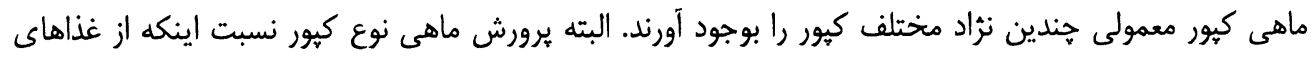




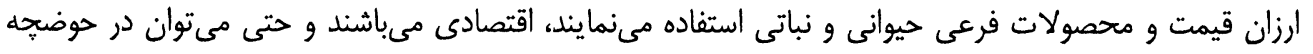

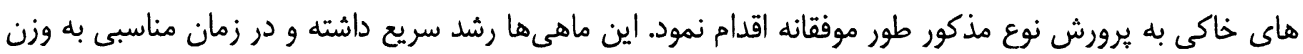

$$
\text { بازار مىرسد (5). }
$$

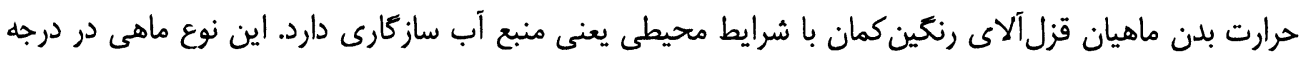

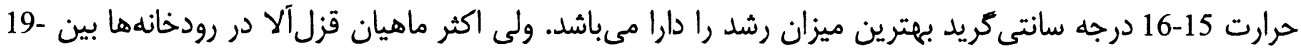

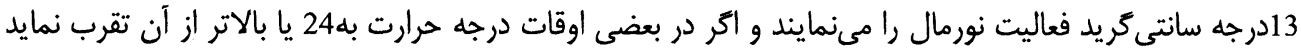

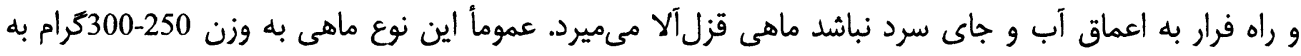

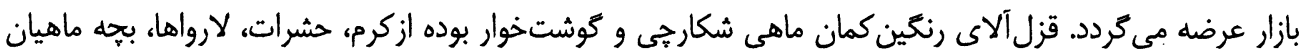
كوجى و غذاهاى تيار شده كاسنتيريت تغذيه مى تُنمايند(7).

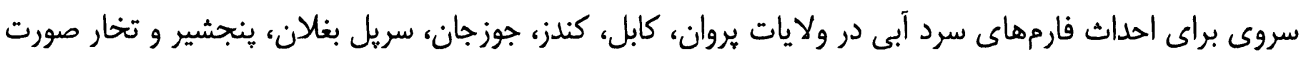

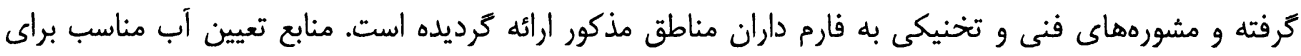

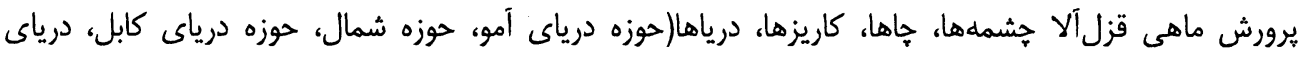

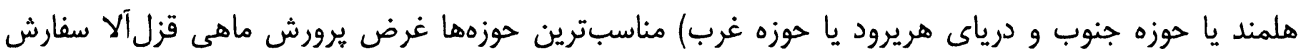

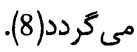
نتيجه

به منظور رفع كمبود يروتين حيوانى، كوشت ماهى مغذى ترين و با كيفيتترين بروتين را تهيه مى دارد. بنأ

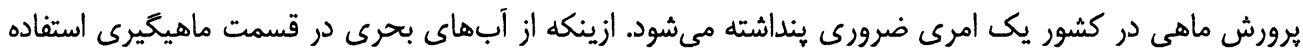

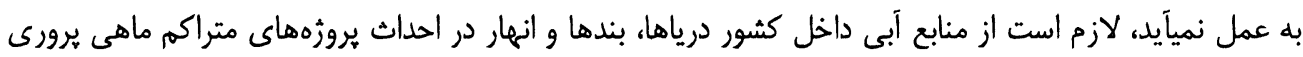

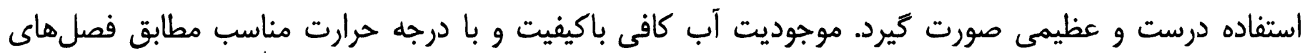

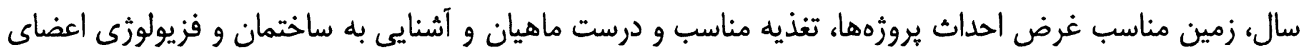

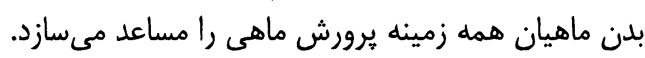

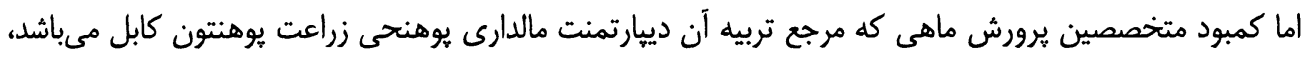

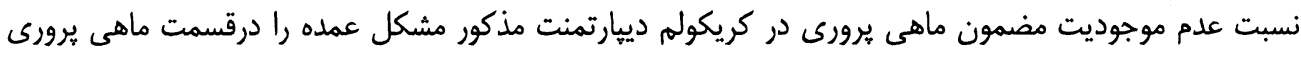

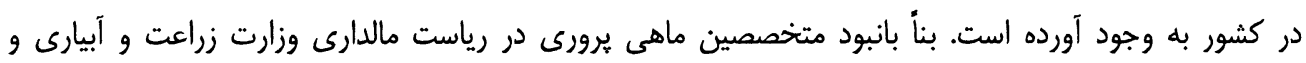

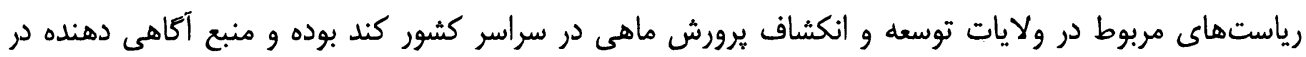

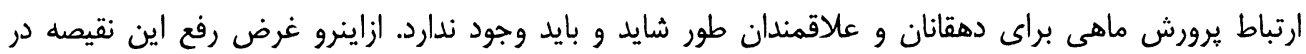

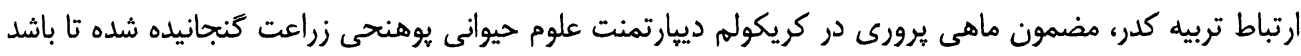

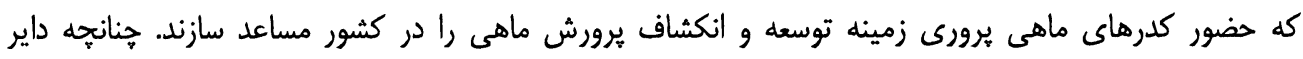

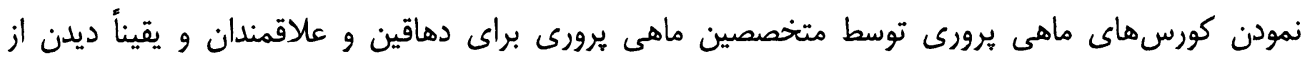


يروزههاى ماهى برورى در هر كوشه و كنار مملكت اثر بارزى در انكشاف ماهى يرورى داشته بالاخره با بلند رفتن

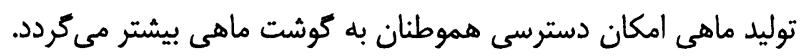
مآخذ:

1.Campbell,R.J and ,T.F. lasley(1975). The science of animal that serve mankind, MCGRAW-Hill book Company USA.PP35-41.

2.FAO 2005 year book, statistic Fishery series Rome, Italy.PP 20-25.

3.FCOMAI 2006 Annual report - Kabul Afghanistan.P6.

4.FCOMAI 2008 Annual report - Kabul Afghanistan. PP 10-12.

5. FCOMAI 2008 Annual report - Kabul Afghanistan. PP 17-19.

6.FAO 2003. Integrated livestock- Fish Farming system Rome Italy.PP 18-29.

7. ستارى، مسعود و معتمد محمد كريم1381. برورش متراكم ماهى ترجمه. دانشخاه كيلان ايران. هاب اول

صفحات 1-7. (- م.

8. ستارى، مسعود و معتمد محمد كريم1381. برورش متراكم ماهى ترجمه. دانشخاه كيلان ايران. هاب دوم

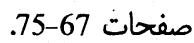


دعبدالرحمن باباكلام هر الرخيز

فن دى باباكلم

سريزه:

دخداي بنبلي رحمن باباعليه الرحمه ددرانه شخصيت، هنريافن به بابكه مبالغه ونه كرو، نويه زركونولويبي

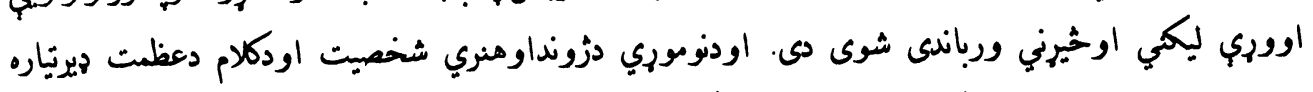

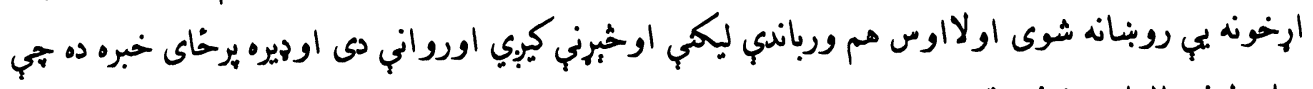

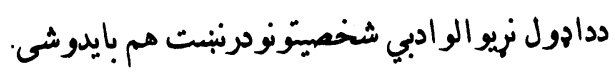
يوه خبره ديادولوورده جي نوموي دكلام مطالعه هره ورخ سري ته نوى مستلي مخي ته بودي اويد

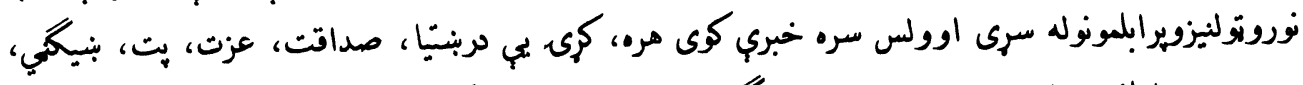

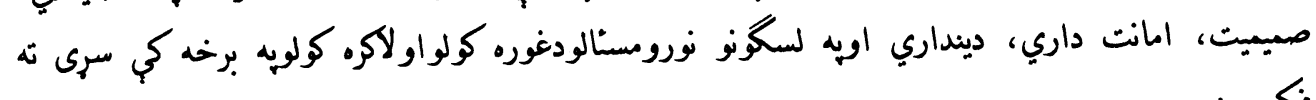
فكروربني.

همدادليل دي جي يوشميراثاريي دزماني كزدونه اوغبارنشي يوبنلي. دزماني اوحالاتويه جيروستونزمنوشيبوكي

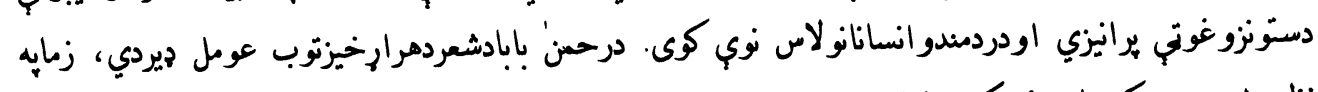
نظريه لومري سركي بايددغوتكوته ياملمرنه وشى أئى 1 - درحن'باباكورني.

r - دوخت حالات اوحاكه فضا. r- دده دشعرگ إخونه. دعبدالرحمن بإبكام هرارخيز فن دى اله دخهي حيب له بركة داساده انسشارنكينه درحمن كيى 
1 - كورنى: درحمن بابامومندكورنى، دعلم اوفضيلت به بنكلوكانويسولل شوى وه به بيبنوربهادركلي كي دده كورنى.

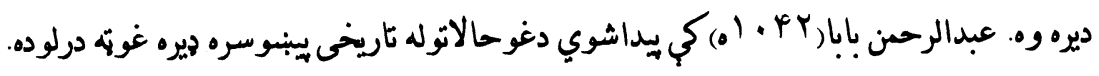

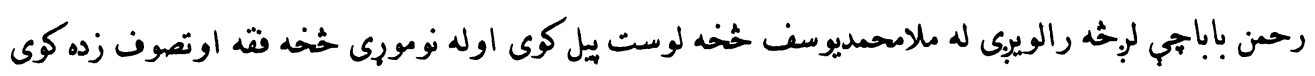

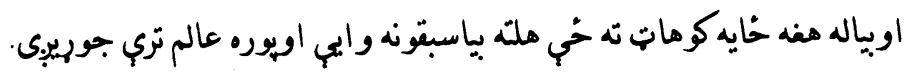
دغودرسونواودوخت حالاتواودنومورى يراخ اوسرشاره طبيعت بياهم دى يرى نه بنود، له مادى دنيابي لرجخان

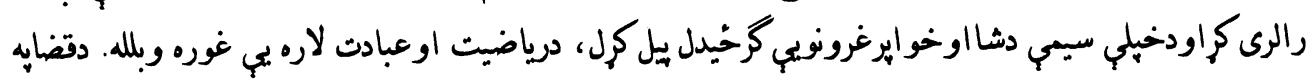

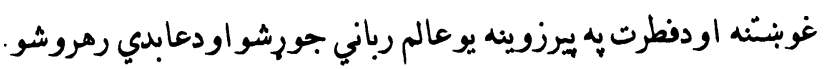

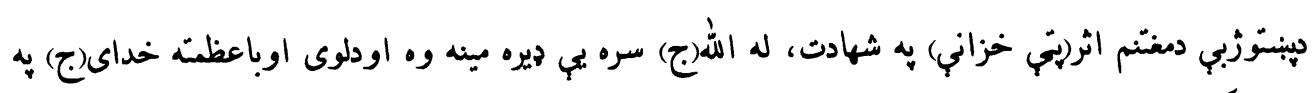
محبت كي بي حيدي ملفلري سره ويلي. له دغوخبروبنكاري جي رحمن بابادخواني به موسمكي خبل شعري لنكرجلولي وى اودشعراوازي به بي يه يبنتى

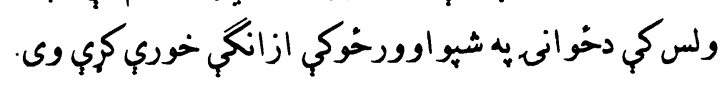
له يوي خوادنومورى علميت، له بلي خواملنكى اوسرشارى، عبادت اوعابديت اوترتولومهمه خبره داجي دده

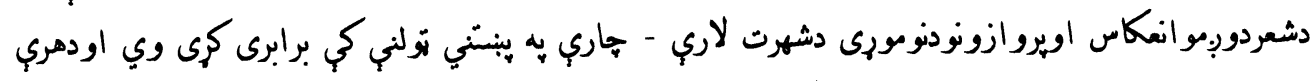

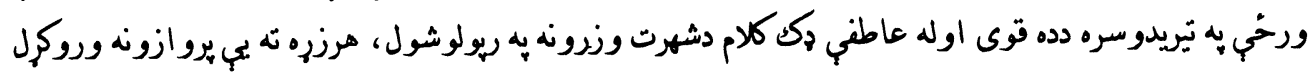

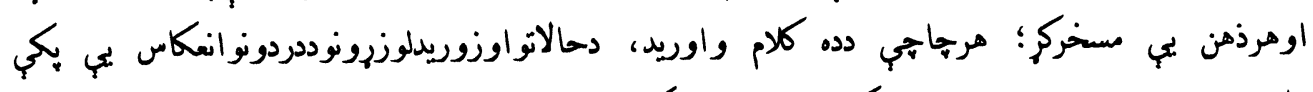

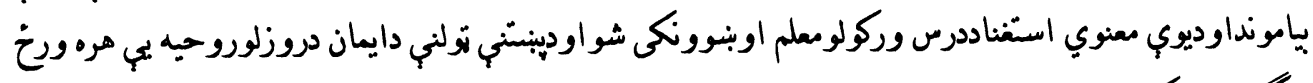

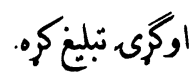

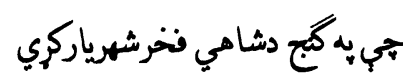

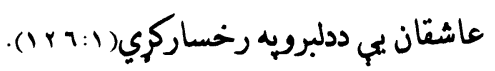

دهردلبردرخسارتصويردنومويى يه شعركي خركدشو ، خهكه دده دادبي شخصيت هنداره دهري ورخي يه تيريدوسر.

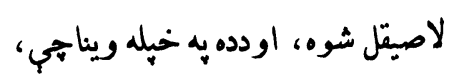

زيورته برورابنكاره شواوبنكه لمر، اوشااوخواته يبي هم ددلبرمخ؛ هماغه وجي درحمن بابادشعرلوستونكى زباتيدل اودشعربازاريابي يجي توديدها 
دخينوولسي روايتونوله مخي جي رحمن بابابه لوميوكي به كودرومودروليكل كول اوجي دكلام جسب يب دجاخبره

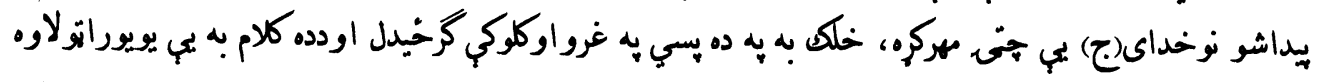

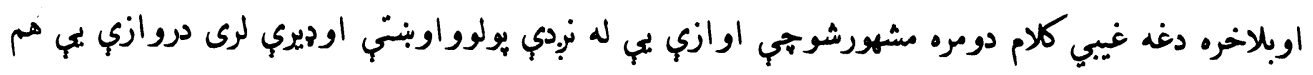

وتخكولى.

اولاله دى هم وريسى واوبنت اويه هرزره اودياراومحلدكي بي درعشق عمارتونه ابادكرل اودمجنون اوفرهاديه

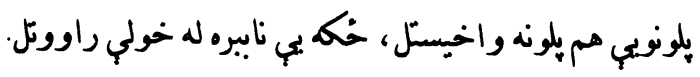

عشق عاشق لره يوهسي بيراستاددي

هي به نه وى بل داهسي بيراستاد

دغه وارهكرامت دعاشقى دى

هي خوك غوث كاندي، خُوك تطب، اوخوك اوتاد...

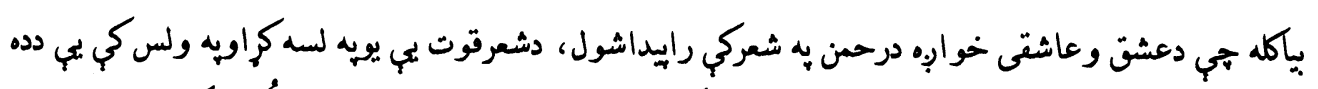

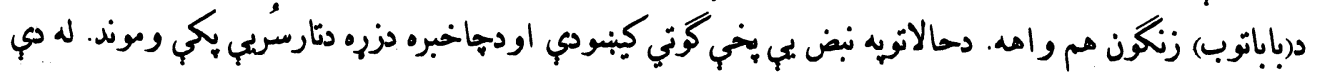

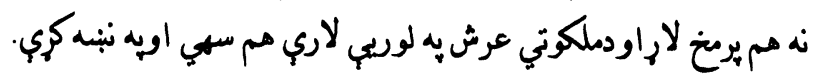

هي يبي خاوري كرصورت دستّابه دركي لئي

سرترعرشه دى وكنبلى دى زماروح...

اوخهل روح بي خهيل يارته حوالدكراويارهم دابدى زوندحو اله ورلاسليكك ماه.

دكلام ملامي دوخت اوخلكود(عقل كل) به لاسونه كلكه وروترل شوه اوكلام يب خوجنده باكيقة اوبآكيته

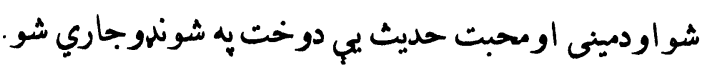

هو ! دغدكلام ورخ به ورخ لكه طلايب يهلوخى ديارانودديارخواته خان غزول يل كمل، ان تردي جي دميرويس خان

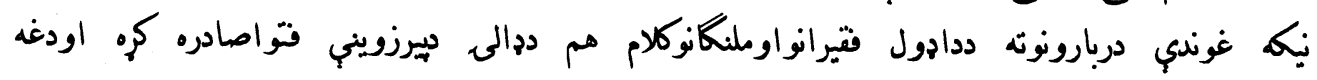

$$
\text { فتو اددرباراوولس فتواهم شوه. }
$$

زه مكوب غوندي بيه بته خوله مويايم 


\section{خاموشي خُاتيرى كاترغوغازما}

به يَه خوله دايمان به طاقت دوخت دحادثوممثل هم شو. ددوستانولياره دفال خورئ اودغليمانولياره دكين اوسنكراسباب شو. تئه

دوخت دشاهاوشاهانه لاربنوداودوخت دظالمانويرسرديري توري گوزاراويه اصطلاح دطاغوتي حالاتوداره.

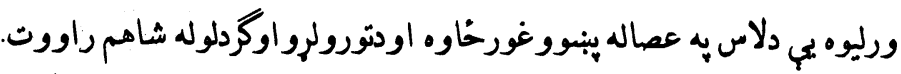

$$
\begin{aligned}
& \text { تجي اسمان بي مخ بت كزى به سحاب و } \\
& \text { خداى وماته بنسكارهكرهغه لمربيا } \\
& \text { جي رقيب راته ترلى يه زنخيرو } \\
& \text { خهل حيب راباندي يرانت هغه وربيا... }
\end{aligned}
$$

اودحيب به فضل ومرحمت دزمان دفتوله تورداغه يه يومخيزهول رآكوبنه هم شواودرقيب يه لاس تزلى ورونه بيب هم دايمان به تدبيريرانستل

2- دوخت حالات: وختونه ويرخله دانسان به برخليكك كي غوره رول هم لوبولئ شى اوكله خو انسانان هم دعثل

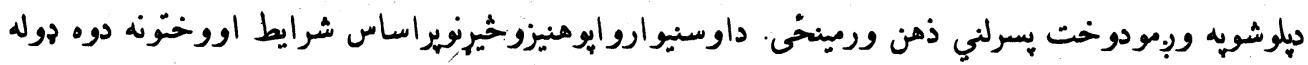

اغيزى يرانسانانوبندي: وبردي:

$$
\text { الف: مشبتي، ب منفي- }
$$

مثبّي يدي ماناكه جهبري انسان يدي وتوانيده هي د "سازه اوناسازه" زماني اوحالاتوسركنه نه ايلدونكى سمن(اس)

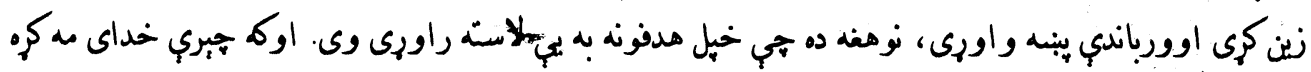

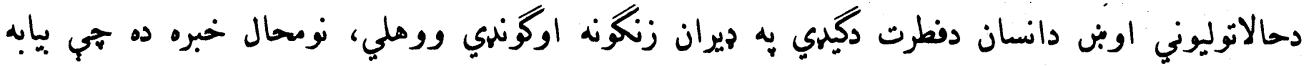

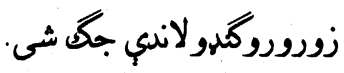

رحمن بأبادخيل وخت اومهال ديوحساس، دراكن صوفي متفكيه توكا خيل تولنيزرسالت درك اودغه اصالت بي

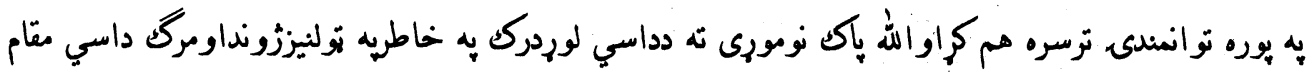

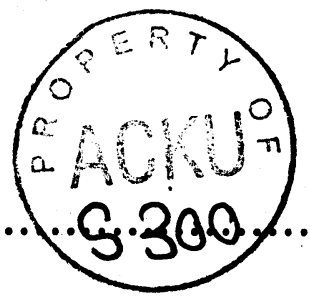




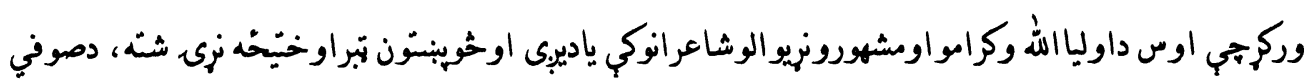

$$
\begin{aligned}
& \text { عبدرالرحمن شعربه وركي ازانگخي خوروى. } \\
& \text { جي منكيري اعتراضكولاي نشى } \\
& \text { دادشعردى رحمانهك اعجاز... }
\end{aligned}
$$

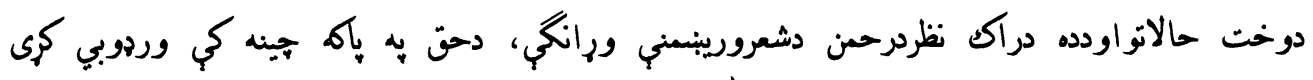

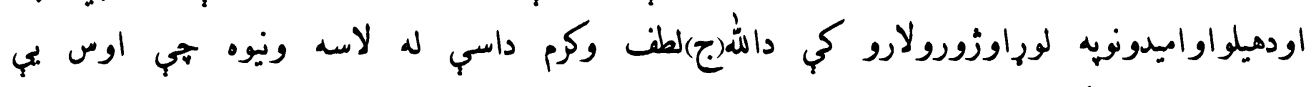

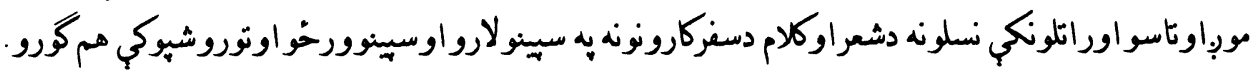

درين راه اميديج دريجيج

مرالطف تومي بايددكرميج...

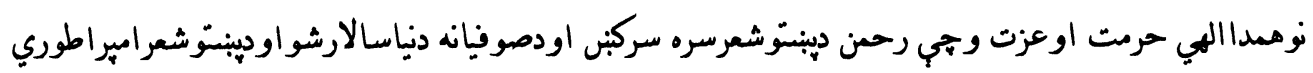

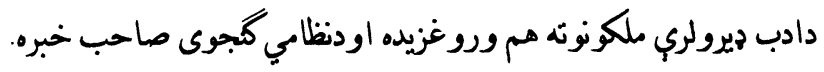

$$
\text { اكرخضر، براب حيوان كنشت }
$$

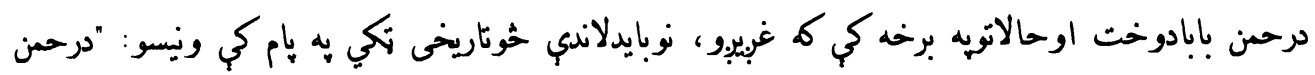

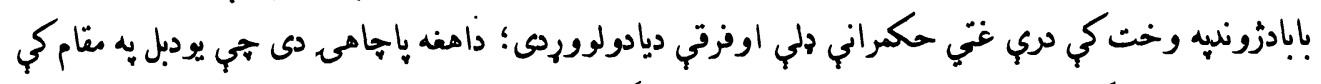

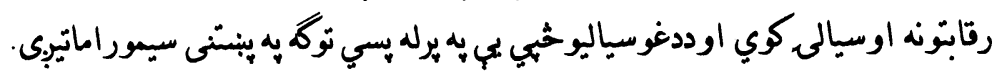

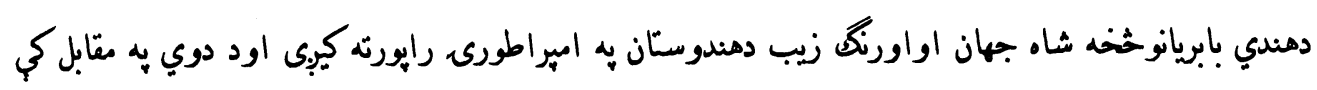

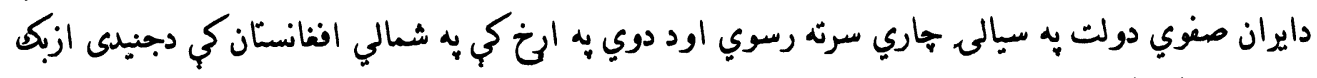

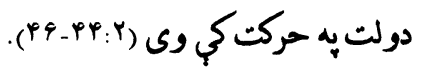

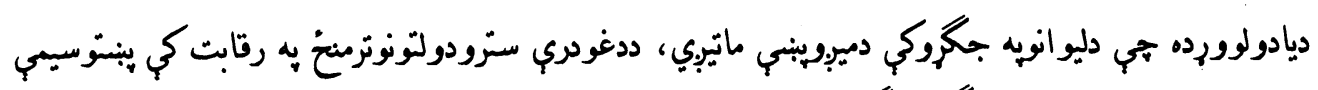

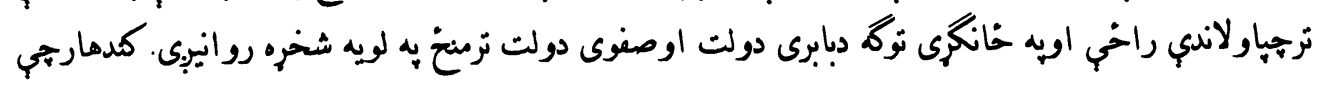


دخيل ستراتيزيكي اواتصطادى ارزبنت له مخي ددغودولتونوياملرنه خاته راواروله اومريوه زيارويسته جي دهنه

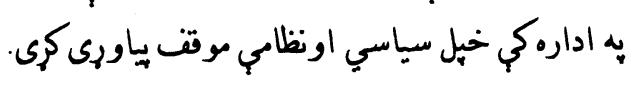
صفوى دولت حكران دويم شاه عباس جي دكدهاراداره به خيل لاس كي واخيسته نودبابريانوسره دسرحدكبنه

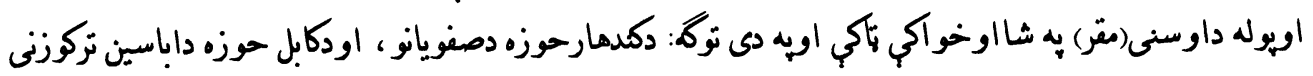

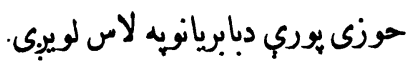

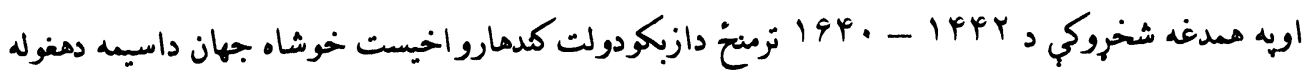

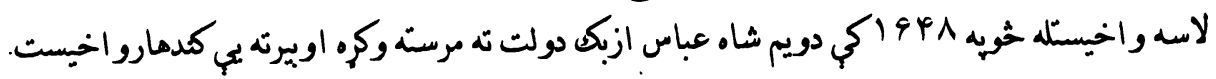

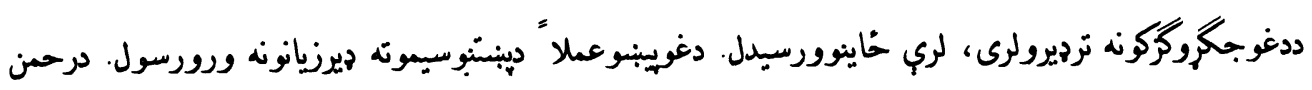

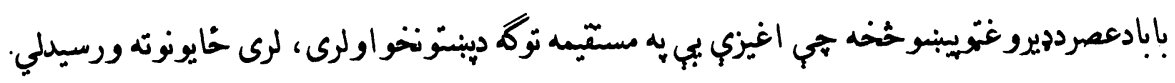

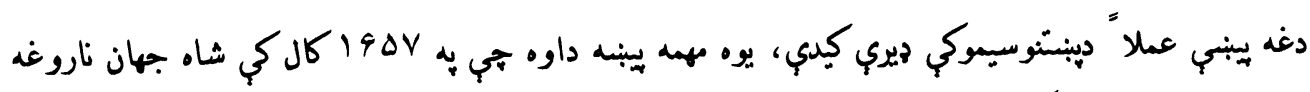

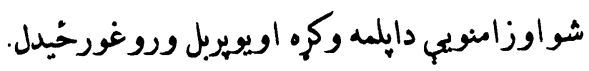
دغوتاريخي يبنبواوماجراوويه هغه وخت كي هيخوك به كرايري نه بنودل اورحمن بابايبي له خرقه بوشى سره

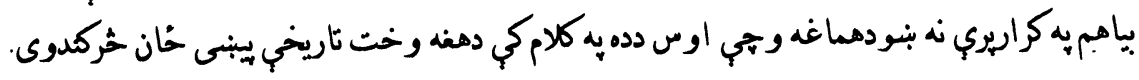
زموبياورى شاعر رحمن باباسره له دي جي دنرم طيعت خاونداوصوفي شاعرو، خوبياهم دهغويبنوزوندي

$$
\begin{aligned}
& \text { تصويردده به كلامكي داسي خركديدي. } \\
& \text { اورنك زيب، جي و، فقير } \\
& \text { جي تتمع بي وهبه سر } \\
& \text { وتويح، وته بي شاهكي. } \\
& \text { هي قارشه به افسر } \\
& \text { خويب هومره ققيري وه } \\
& \text { جي خهنه ووميسر } \\
& \text { جي فلكك يب ياري وكر. }
\end{aligned}
$$


نوريب خلكك كره مسخر...

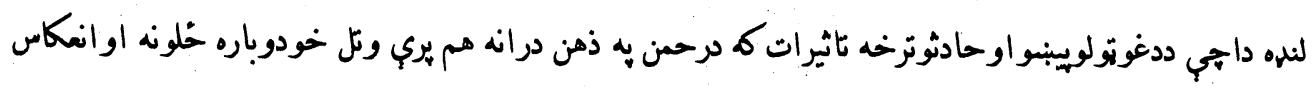

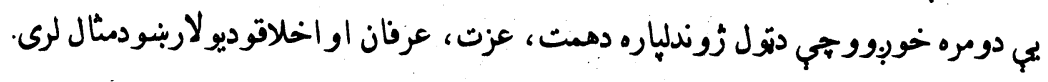
دهاغوترخويبنواغيزورحمن داسي معلم جوريجهي دتل لياره به ديبنّودكلام سرلارى اوداخلاقويوزبردست

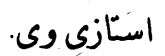

3- كه دعبدا الرحمن بابادكلام تلباتي توب اوكي والئ مطالعه كورنوبايدد دده دكلام تل ته ورنوخو.

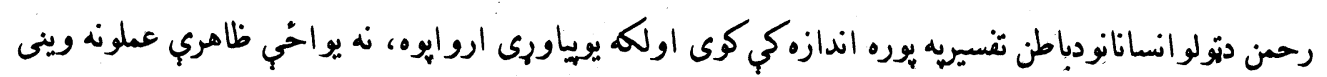

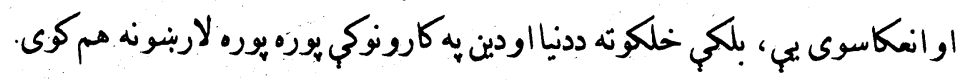

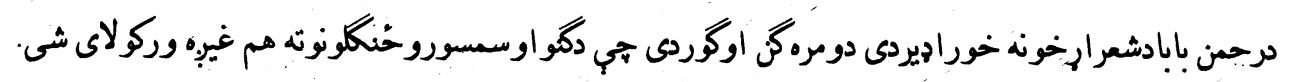

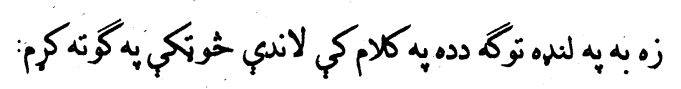

الف- تصوف اومذهب: رحمن بابادتصوف لنكردمذهب يراصولوبرابرجلوي شرع شريف بي معنبره كنلى

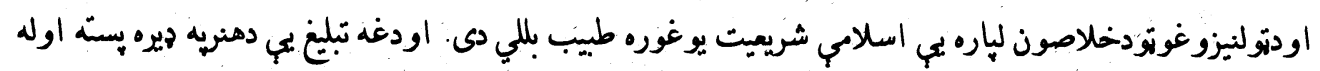

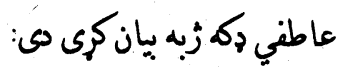

.... دنيابحردى بهيريى

ايني غوندي صنا

خبل خيل مخ بكي ليده شي

كا خوك زشت وي يازبيا...

سالكان دي ندارجي شى

دخيل خمان يه تماشا

هرجي كاهغه به مومي

دنياخاى دى دجزا... 


$$
\begin{aligned}
& \text { كم دانابي ويوهيره } \\
& \text { به روابه ناروا } \\
& \text { ثو اونسسه به مخكي } \\
& \text { سي مت كره به تقوى } \\
& \text { دنيانه دى هغه دين دى } \\
& \text { هي له نهي وي سيوا } \\
& \text { اوطاعت وته ولاروي } \\
& \text { هميشه ترلم ملا } \\
& \text { له حرامويبي برهيزوي } \\
& \text { هم مشغول يه بنج بنا } \\
& \text { كمه بي وي بهز زّه } \\
& \text { همبه جهر، هم خفا } \\
& \text { ددنيادكارلهاره } \\
& \text { فرض لمونّ نهكاقضا } \\
& \text { هم صائم وب درمضان } \\
& \text { هم ذكات كاندي ادا } \\
& \text { كم مي توان دحج رسيبِى } \\
& \text { حج هم اوكاسي بيا } \\
& \text { دايخخه بناد دين مي } \\
& \text { جي بيان بي وكروما }
\end{aligned}
$$




$$
\text { جي بيب يون به داطريق وي هند دي اوليا }
$$

بدي هول عبدالرحمن باباخبله لارد)عرفانى ديد) لاريه "اهدنا الصراط المستقِم" وربرابروب اوديوريبنتى مومن يه

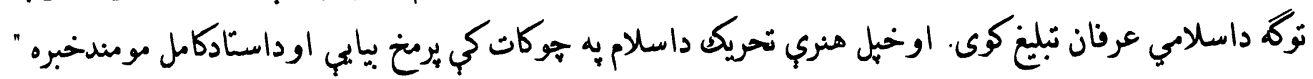

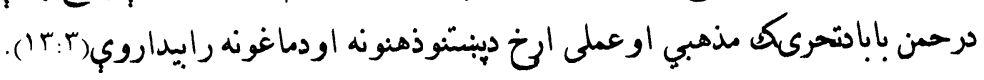

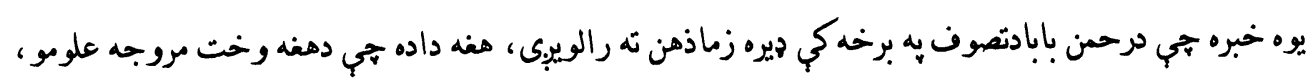

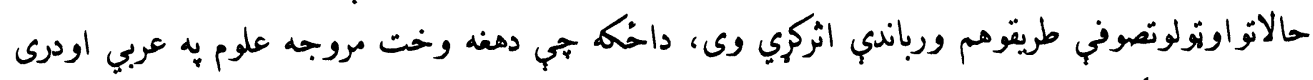

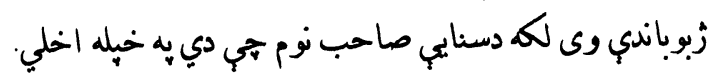

$$
\text { به بِّنْوكي رحمن ووى فارسي كي سنايب.. }
$$

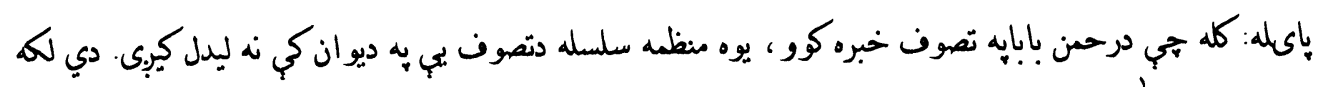

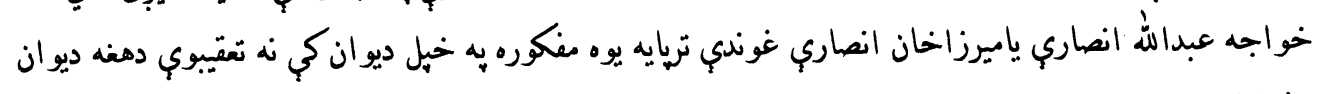

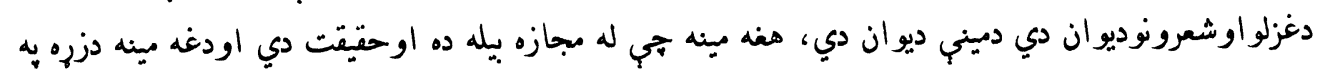

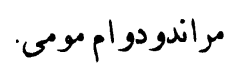

$$
\begin{aligned}
& \text { هغه زره هي خداى روبنـانكاجام دجم شى لـ } \\
& \text { يه دى زرهكي وربنسكاره تمام عالم شى... }
\end{aligned}
$$

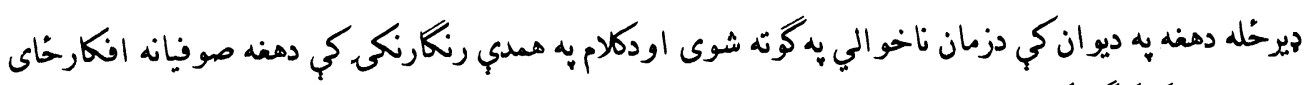

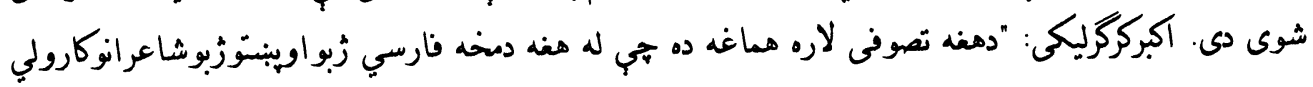
$\cdot(Y \cdot: \varepsilon) 0 s$

$$
\begin{aligned}
& \text { رحمن بابابه تصوفكي له دوبي خان ساتى اووايب: } \\
& \text { جي حاصله ددلبريخانكي شى } \\
& \text { ددويب خبري نكاندي مشتّاق }
\end{aligned}
$$




$$
\begin{aligned}
& \text { هسي محودي دعشت به مي نابكي } \\
& \text { جي خبرنه وي به وصل به فراق(" 9 ) من } \\
& 1 \text { - خُودعشق به غم خانه مي داخل نهك } \\
& \text { بخد نه شودغه عقل خام زما }
\end{aligned}
$$

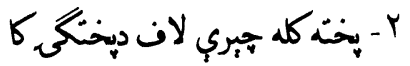

$$
\begin{aligned}
& \text { بختّان دي بدي خُمكي خام دستا }
\end{aligned}
$$

r - دعشت مستله درحمن دشعراوكلام دملاشمزى جوروي. دي لكه حافظ، خيام او اقبال دمحبث زوريه عشت

$$
\begin{aligned}
& \text { كي ويني. رحمن عشت دخبل كاريراو استّادكى. } \\
& \text { عشت عاشت لره يوهسي ير استّادوى } \\
& \text { حوك به نه وى بل داهسب يتراستّاد }
\end{aligned}
$$

$$
\text { دغه واره كرامت دعاشقى. دى }
$$

جي خُوك غوث كاندي، خوك قطب، خُوك اوتاد

$$
\begin{aligned}
& \text { كبج دعقل حارشه دعاشتّ ترخاخُكي اوبنكي } \\
& \text { نه خرواردعقل ، نه دعشتّ يوه دانه } \\
& \text { اوعرش ته رسيدل هم دعشق محعول كلي. } \\
& \text { هي هُ يوقدم ترعرش بوري رسي } \\
& \text { ماليدلي دي رفتارد دروشيانو }
\end{aligned}
$$

اوياعرث ته جكيدل داخلاص محصول كي. 


$$
\begin{aligned}
& \text { كه له خمكي واسمان ته ختل كران دى } \\
& \text { داسفريه يوهام دي داخلاص } \\
& \text { هي خبركامخلصان له علم غيه } \\
& \text { داهمه واره الهام دى داخلاص }
\end{aligned}
$$

3- اخلاق: درحمن بابابه كلامكي اخلاقي بله درنه ده. دده كلام له وفا مالامال دي، دانصاف تله دهرجابه لاس

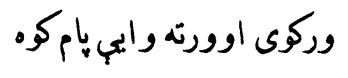

$$
\begin{aligned}
& \text { كه خوك تله دانصاف به لاسكي مركمى. } \\
& \text { خهل تهّ اودبل اس به برابركمى }
\end{aligned}
$$

$$
\text { لاس به سريه سينه ايبنئ وهرجاته }
$$

$$
\begin{aligned}
& \text { منصفانولره بويه جي انصافكى } \\
& \text { نه هب نغوتة كيى دحرص اودهوا } \\
& \text { دسرى به خاطرهرخه هرخه كرخى } \\
& \text { هسي نه جي واره وكى روا.... ( المخ دىوان). } \\
& \text { 4- دانسانانوتويير: }
\end{aligned}
$$

رحمن بابادانسانانوتويريه يوه معنوى بيرايهكي كوري، انصاف دانسانت غوره اصل كمى اويدي برخهكي

$$
\text { دالهى كلام تفسيركوى. }
$$




$$
\begin{aligned}
& \text { خوك اعلى دى، خُوك اوسط دي خوك ادنى } \\
& \text { دهرجاحرمت به خبله اندازه دي } \\
& \text { نه جي مومى تقرخاى دامرا... } \\
& \text { كا خبلى خبري رالنديك كم نورايم جي: } \\
& \text { دعبدالرحمن بابادشعرتلنيزاخخ لايياويى دى، سياسي اوعقيدوي ارخونه يبي لامتوردى، مذهبونه سره يوكي اويه }
\end{aligned}
$$$$
\text { تولنيززوندكي انصاف اوعدل ته ارزبنت وركوي. }
$$

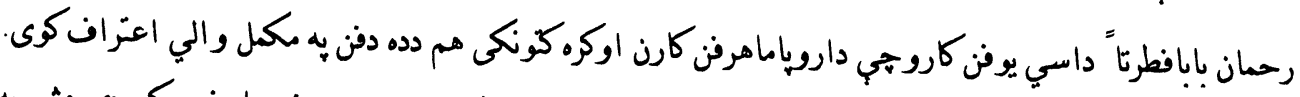

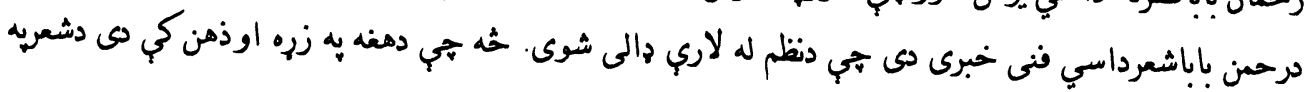

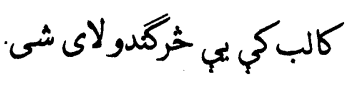

دلته به دده دكلام اوفن داعجازيوه بيله دحسن اختّام لياره راو اخلمكوم خي دى له خيل اشنا سره خبري كموى:

ته جي ماته وابي خب به خثكوى زرا

نه درمعلوميبِى دغه خيل جوروجفا

ته جوروجفاكري، زه زراكوم دلبره

ستاكه دغه نه وى دابه هم نه وى زما

داخصلت كه ستاوى، كه هم تل به دغه شان وى

نه رامعلوميِّى د دردمنددزره دوا

$$
\text { يودستاماني شى، بل غروردرقيبانو }
$$

واريه وارمى وزثني كله هغنكله دا

هرجه عاشقي كاكه يه قطع افلاطون وى

زه خويبي مجنون كمركة نن وى كه صبا 


$$
\begin{aligned}
& \text { هيخ بمي به كارنه دي رحمن تا غواري دلبره } \\
& \text { دازمارضاده باقى هر بجي ستّا رضا. }
\end{aligned}
$$

ماخذونه:

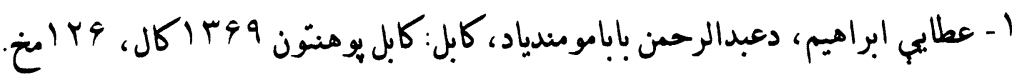

$$
\begin{aligned}
& \text { Y- رساسيرسول(سريزه) دعبدالرحمن بإباديوان.(F) }
\end{aligned}
$$

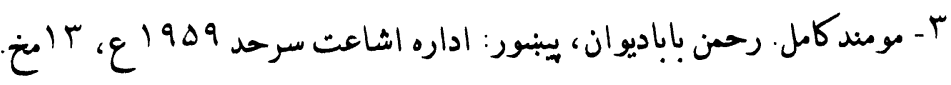

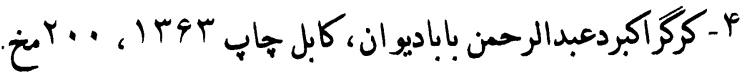




\section{تاثير وزن بياز و فاصله \\ كشت بالاى حاصل زعفران}

زعفران با نام علمى كركوس ساتيوس Crocus sativus از خانواده زنبقيان(Iridaceae) ميباشد. در برخى منابع

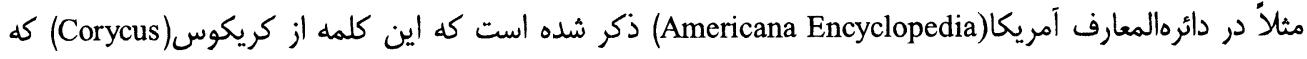

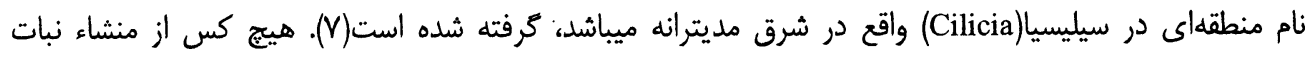

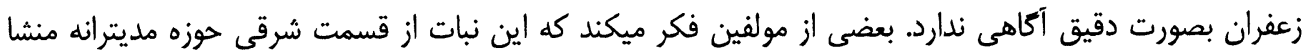

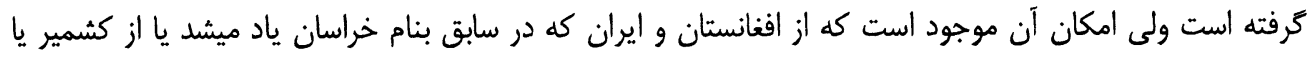

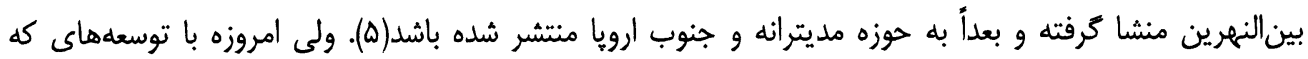

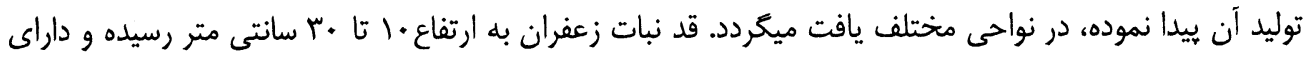

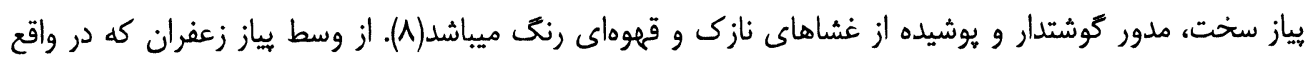

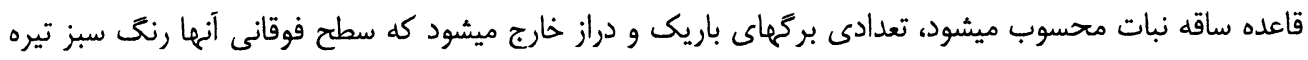

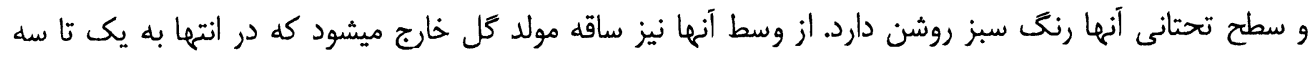

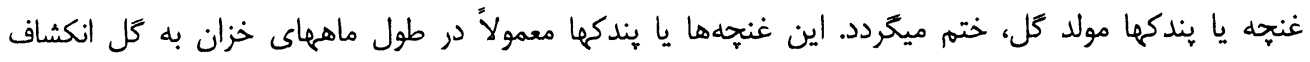

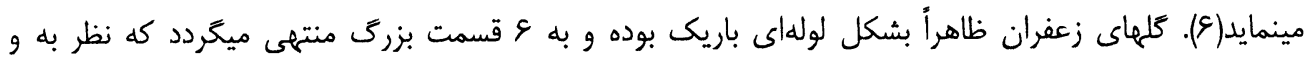

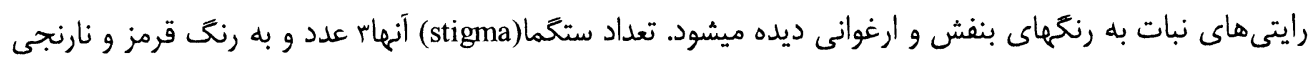

زعفران يكى از مهمترين محصولات و گرانبهاترين ادويه جهان است كه نقش قابل توجهى را در وضعيت اقتصادى

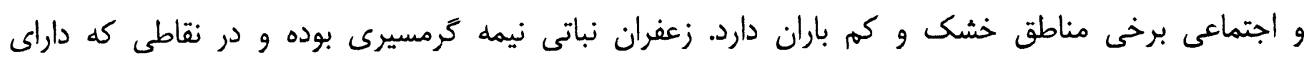

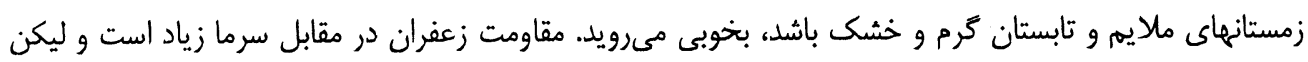

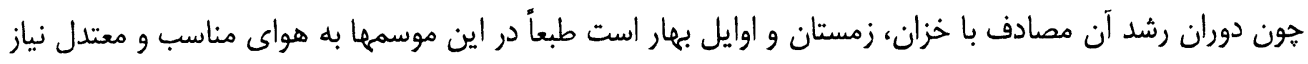

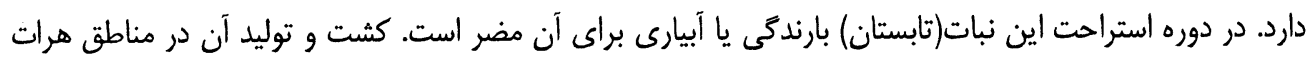

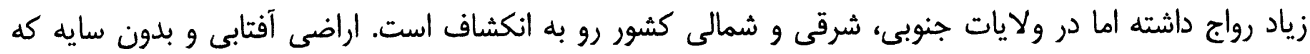

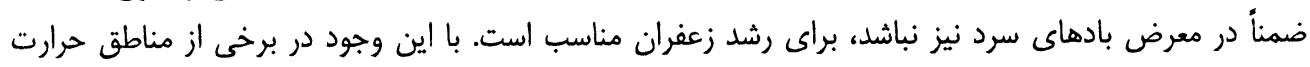

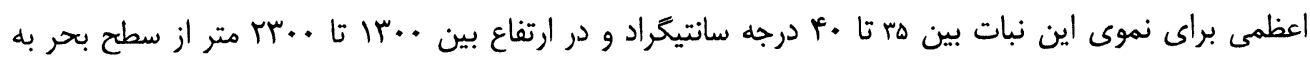

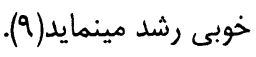

استعمال زعفران:

زعفران در بسيارى از فرهنگهاى كشورها استعمال و مصارف زياد داشته از جمله مورد استعمال آن در 


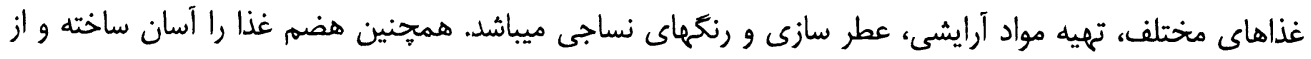

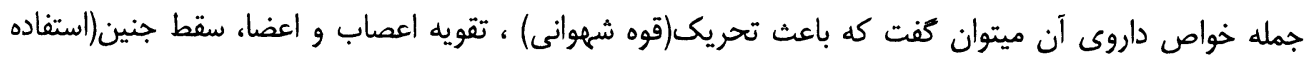

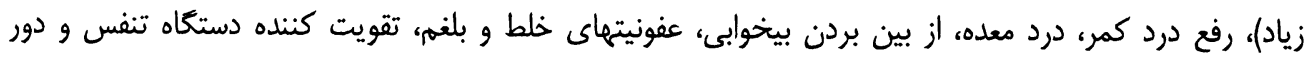

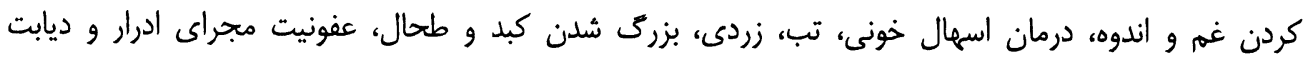

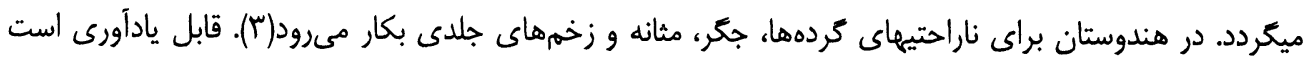

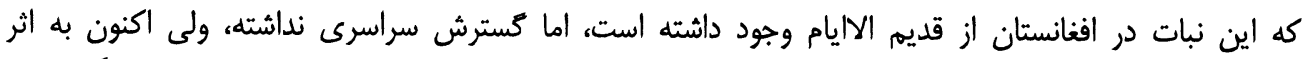

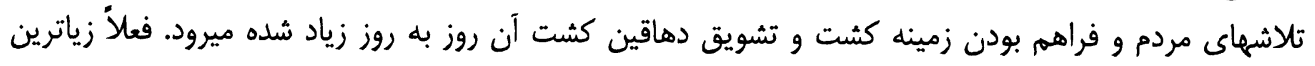

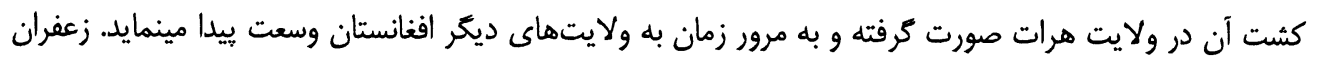

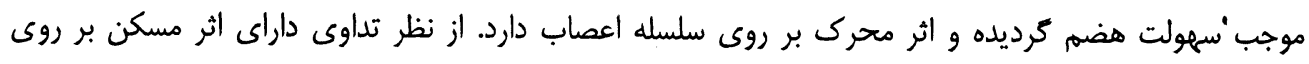

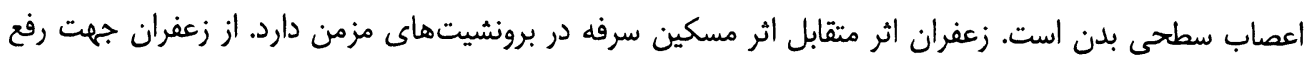

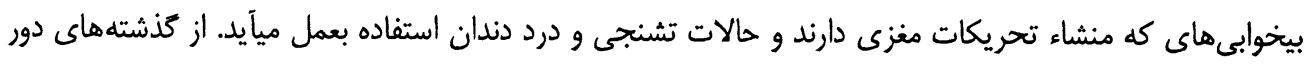

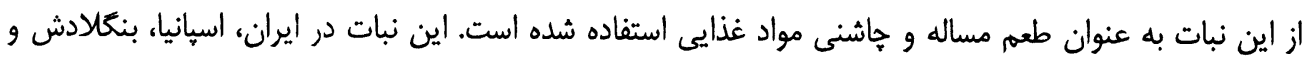

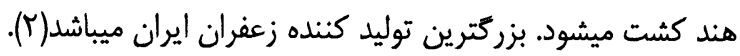

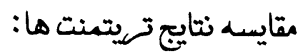

درين تحقيق تاثيرات وزن بياز و فاصله كشت آنها بالاى حاصل زعفران در ساحه مختلف كابل و ميدان نشان داده شده كه نتايج تحقيق در جدولهاى زير با هم مقايسه ميكردد.

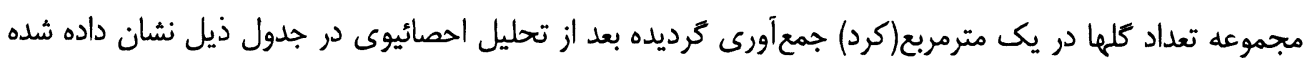
است.

جدول ا: تاثيرفاصله كشت بياز زعفران بالاى توليد تعداد كل در فى كرد در هر دو محل(از تاريخ وعقرب الى 1 ג

\begin{tabular}{|c|c|c|c|c|}
\hline \multirow[t]{3}{*}{ اوسط فاصله درهر محل } & \multicolumn{3}{|c|}{ فاصله كشت } & \multirow[t]{3}{*}{ محل تجربه } \\
\hline & هاسانتى متر & • اسانتىمتر & ل لهانتىمتر & \\
\hline & \multicolumn{3}{|c|}{ تعداد كل فى كرد } & \\
\hline 9.15 & גזיז & תז.Tr & س ه. سالف & كابل \\
\hline r.tet & אוז' & (ITH & rifv & ميدان \\
\hline S.T & אזיד & ritr & •م، "آلف & اوسط محل كشت \\
\hline
\end{tabular}

كوجكترين تفاوت(LSD): 


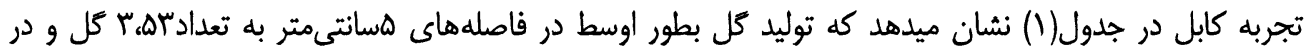

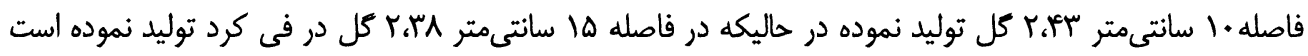

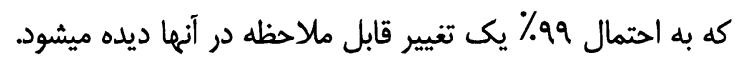

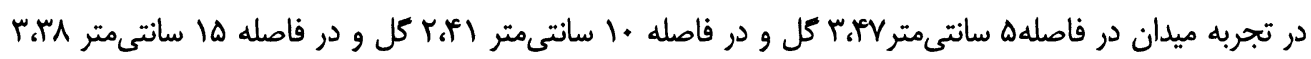

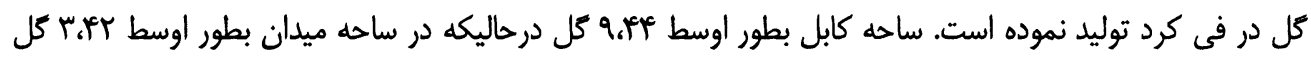
توليد نموده است. بناً يكى تغيير قابل ملاحظه در دو ساحه ديده شده است.

جدول r: تاثير وزن يياز زعفران بالاى توليد كل در فى كرد هر دو محل(از تاريخ ععقرب الى ^זعقرب)

\begin{tabular}{|c|c|c|c|c|c|c|c|}
\hline \multirow[t]{3}{*}{ اوسط وزن } & \multicolumn{6}{|c|}{ بياز زعفران نظر به وزن ان به كرام } & \multirow[t]{3}{*}{ محل تجربه } \\
\hline & 11 & 1. & 9 & $\wedge$ & $\mathrm{v}$ & 8 & \\
\hline & \multicolumn{6}{|c|}{ تعداد كل در فى كرد } & \\
\hline Q.ह₹ & 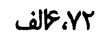 & بهب & צ' & S.rt & 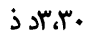 & (1.54 & كابل \\
\hline r.ET & 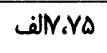 & TI & דוא & 28.99 & 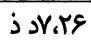 & S, T.Tr & ميدان \\
\hline $7 . \varepsilon \mu$ & I.VE & 1.74 & $\varepsilon, \varepsilon r$ & 1.51 & 0.51 & T.Tr & محل هر دو \\
\hline
\end{tabular}

كوجكترين تغاوت(LSD): אبr

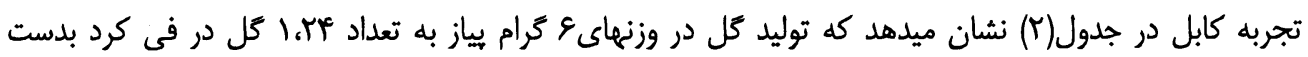

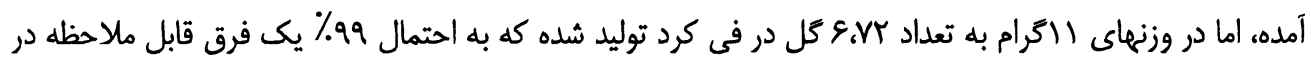

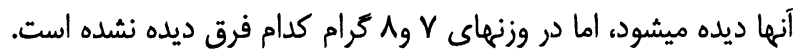

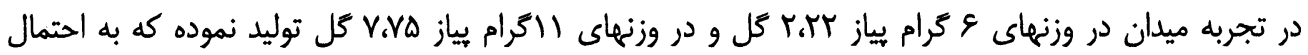

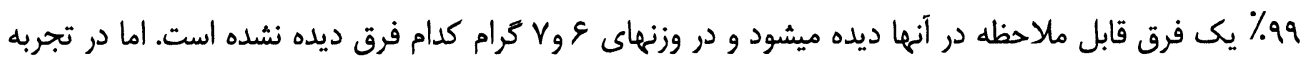

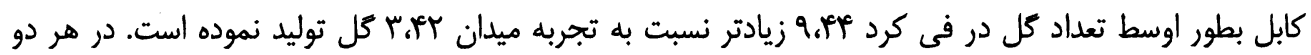

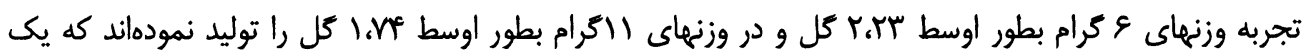
فرق قابل ملاحظه در آن ديده ميشود. جدول": اوسط تعداد كلما در هركرد در هر دو تجربه كابل و ميدان وردى

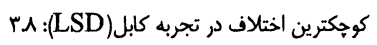

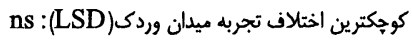




\begin{tabular}{|c|c|c|c|}
\hline اوسط تعداد كل هر كورد در كابل وميدان & ميدان & كابل & 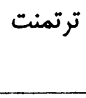 \\
\hline ط،r. & 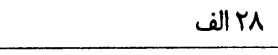 & rr & 1 \\
\hline ض r.rf & 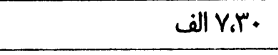 & ض V.rV & $r$ \\
\hline 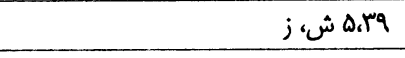 & 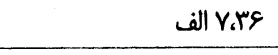 & & $r$ \\
\hline 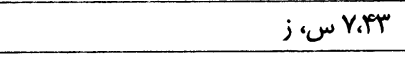 & أl الف & & i \\
\hline 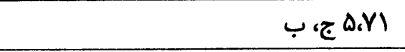 & 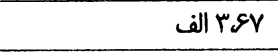 & ب Q.VD & $\Delta$ \\
\hline الف AAY الف & م. 1الف & VAA & 8 \\
\hline ق ق ع.r. & V.r. & וז' ف، & v \\
\hline ع، & ع الف & $\varepsilon ، b r$ & $\Lambda$ \\
\hline b، ض.rV & 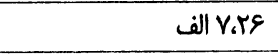 & b، b.rA & 9 \\
\hline jPQ & qr.r r الف & $j, V_{\triangle} \Delta$. & 1. \\
\hline 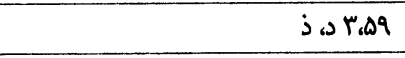 & V V.DA & 28. & 11 \\
\hline بv & ع V الف & جr & ir \\
\hline J،EVIA & 11 الف & (19.19 لمبق & ir \\
\hline 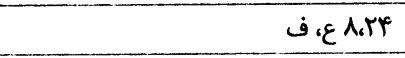 & r.r.r الف & צr. ف، b & if \\
\hline ع.غ & 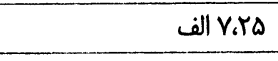 & $\dot{\varepsilon} ، r V$ & 10 \\
\hline j. & بr.ry الف & س ش، س & 19 \\
\hline,$\omega \Delta_{\Delta} \Delta \Delta$ & الف Y.AY & , r.Ar & iv \\
\hline ج $\triangle \Delta S \Delta$ & الف & $j ، 8$. & 11 \\
\hline girt & rite & 9.49 & اوسط \\
\hline
\end{tabular}

كوجكترين اختلاف تركيب فاصله كثت ووزن بياز هر دو تجربه(LSD) :

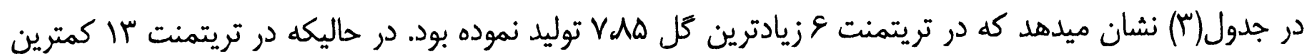

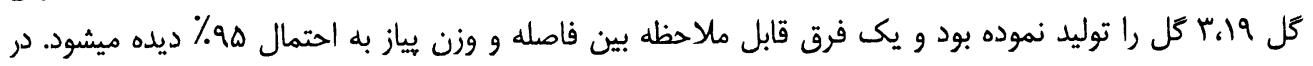

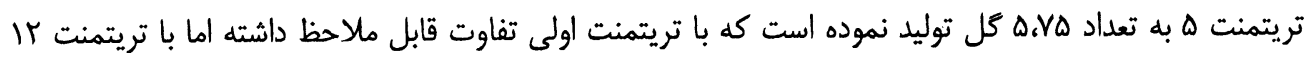

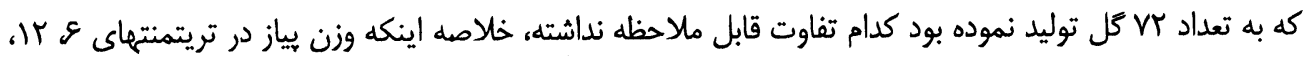

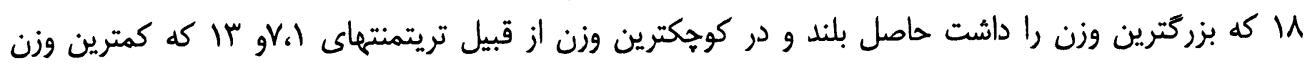

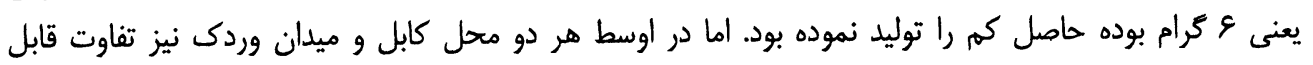
ملاحظه ديده ميشود. در تريتمنت و زيادترين كل كرد ترتمنت ك، VIN

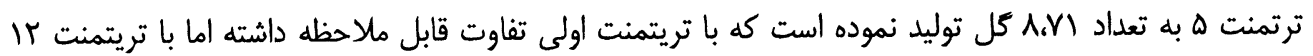

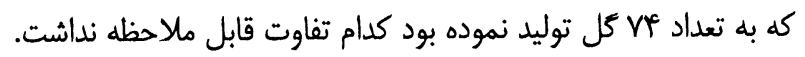




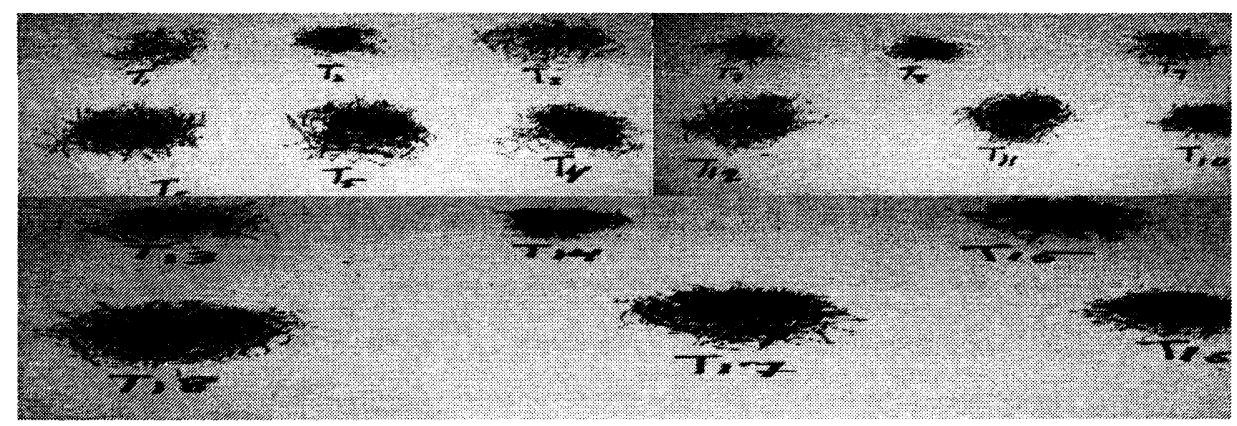

حاصل تريتمنت ها زعفران

جدول ثا: تاثيرفاصله كشت يياز زعفران بالاى توليد گل فى نبات در هر دو محل(از تاريخ وعقرب الى ^זعقرب)

\begin{tabular}{|c|c|c|c|c|}
\hline \multirow{3}{*}{ محل اوسط فاصله درهر } & \multicolumn{3}{|c|}{ فاصله كشت } & \multirow[t]{3}{*}{ محل تجربه } \\
\hline & هاسانتىمتر & • اسانتىمتر & هسانتى متر & \\
\hline & \multicolumn{3}{|c|}{ تعداد كل در في نبات } & \\
\hline$r_{6}$ & الف الف & ا، ب ب & ا،اب،ج & كابل \\
\hline 1 & الف، & اب & "* & ميدان \\
\hline 1.1 & |lfilla & اباب & ${ }^{\Lambda_{1} \cdot}$ & اوسط محل \\
\hline
\end{tabular}

كوجكترين تفاوت(LSD): (L)

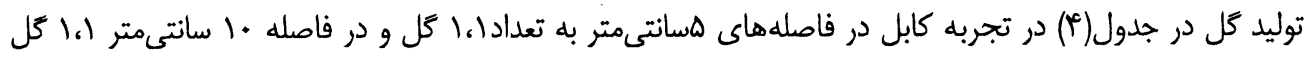

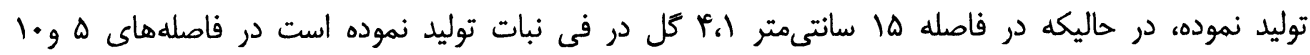

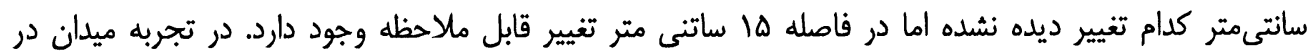

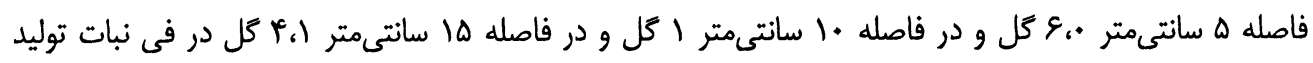

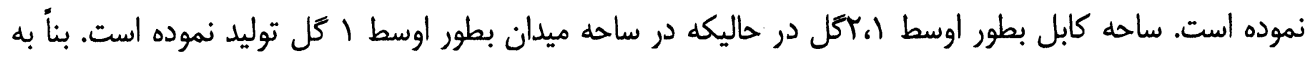
احتمال 99\%يك تغيير قابل ملاحظه در هر دو ساحه ديده شده است.

جدول ه: تاثير وزن يياز زعفران بالاى توليد گل فى نبات در هر دو محل(از تاريخ ععقرب الى دזعقرب)

\begin{tabular}{|c|c|c|c|c|c|c|c|}
\hline \multirow[t]{3}{*}{ اوسط وزن در هر محل } & \multicolumn{6}{|c|}{ بياز زعفران نظر به وزن(كرام) } & \multirow[t]{3}{*}{ محل تجربه } \\
\hline & 11 & 1. & 9 & $\wedge$ & $\checkmark$ & 8 & \\
\hline & \multicolumn{6}{|c|}{ تعداد كل در في نبات } & \\
\hline Y.) & الف 9.1 & ب & ج & 29. & $j د A_{c}$ & $f \cdot$ & كابل \\
\hline 1 & الف A A الف & 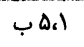 & $8^{9 .}$ & $2 V_{6}$ & jos. & j & ميدان \\
\hline 1.1 & 9.1 & 7.1 & 1.1 & $A_{6}+$ & $V_{6}+$ & $76+$ & اوسط هر نو محل \\
\hline
\end{tabular}

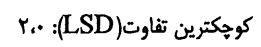

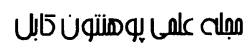




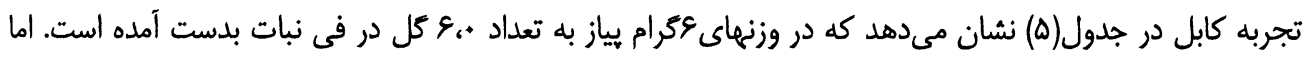

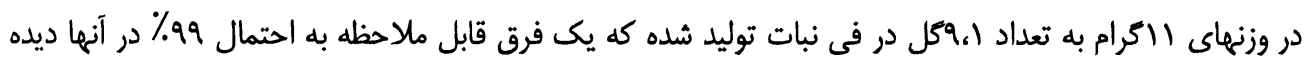

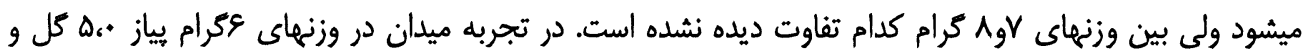

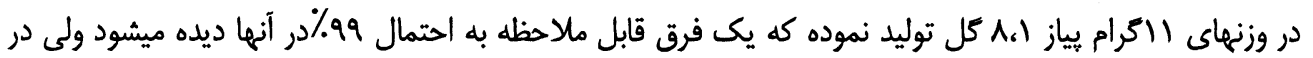

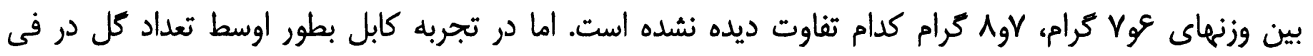

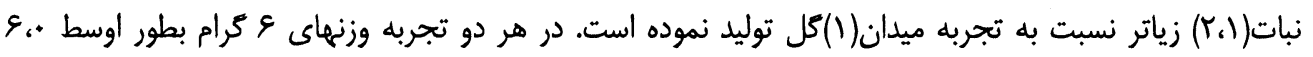

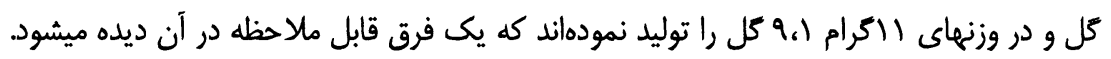
جدول و:خلاصه اوسط تعداد كلها در فى نبات در هر دو تجربه كابل و ميدان وردى

\begin{tabular}{|c|c|c|c|}
\hline 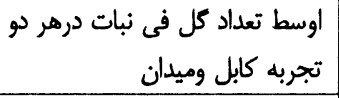 & اوسط تعداد كل فى نبات در ميدان & 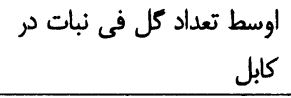 & ترتمنت \\
\hline ••، ق، ف & F، ق. & الف V،. & 1 \\
\hline ••، ف، ض & b.Jfi. & ل & $r$ \\
\hline ضY.• & $b_{،} \varepsilon \Delta_{c *}$ & 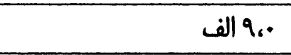 & $r$ \\
\hline ض، br.• & $b_{c} \dot{\varepsilon} \Delta_{c \cdot}$ & الف & r \\
\hline$j r_{1}$ & ••، ش، س ش & | & $\Delta$ \\
\hline د.j4.1 & jol & الف 1A، & 9 \\
\hline ل & b، b، b، & 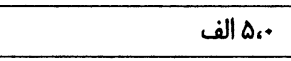 & $\checkmark$ \\
\hline 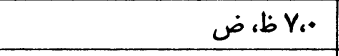 & ض. س، س. & لفN"* & $\Lambda$ \\
\hline 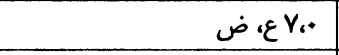 & w.• & V V،• & 9 \\
\hline زاس، & $j, j l$ & الف rالف الف & 1. \\
\hline $2 \Delta_{1} 1$ & $\Delta \Delta_{11}$ & (ه) الف الف & 11 \\
\hline (9.1 ج، ب & $e^{9.1}$ & |لف & ir \\
\hline ض غ Y.• & b، bs:* & الف V،. & ir \\
\hline ش & ) & ل & if \\
\hline 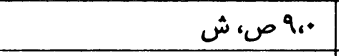 & & الف & 10 \\
\hline $2, p_{01}$ & jar $r_{1}$ & | & 18 \\
\hline r & rاب & الف & IV \\
\hline r.r. & S T.r. الف & r. 1 الف & 11 \\
\hline 1.1 & 1 & $\left.r_{6}\right)$ & اوسط \\
\hline
\end{tabular}




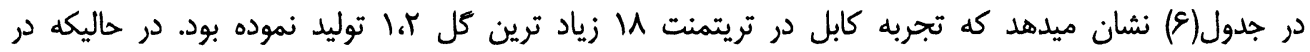

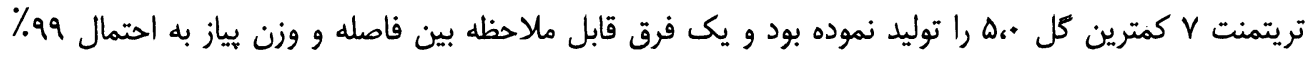

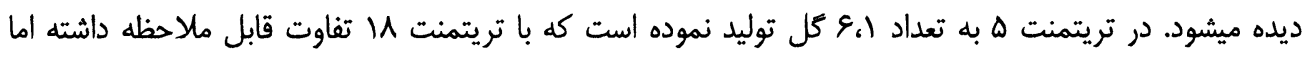

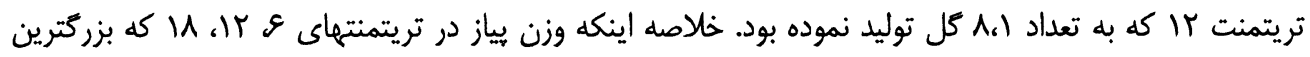

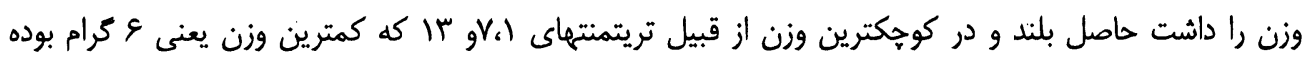

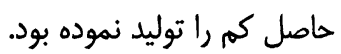

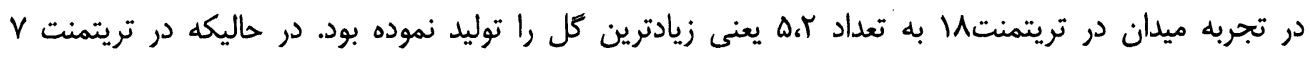

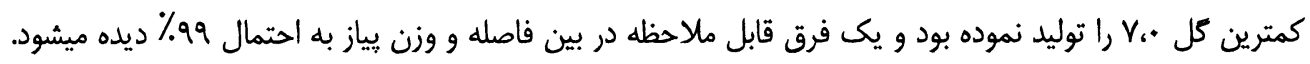

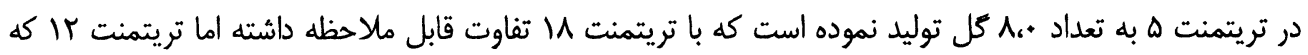

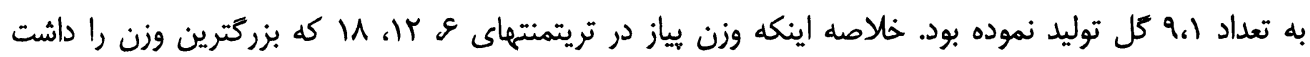

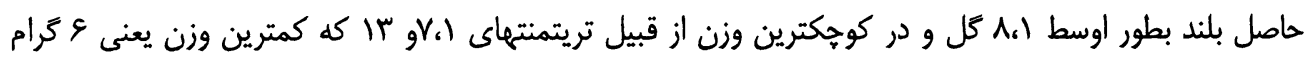

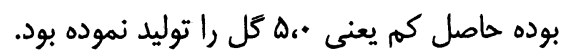

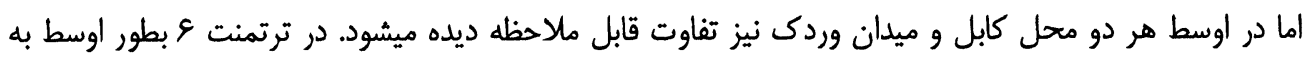

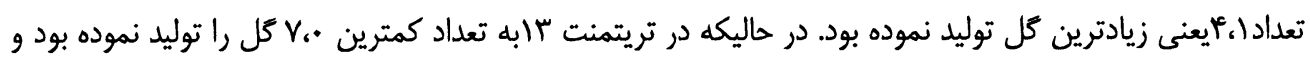

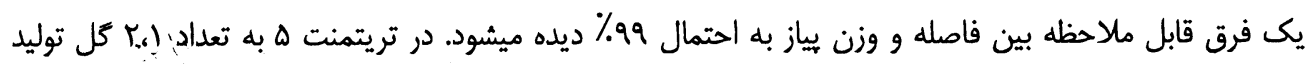

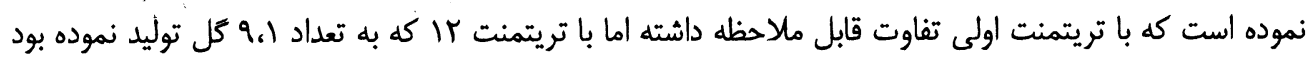

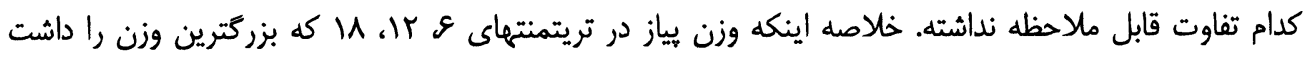

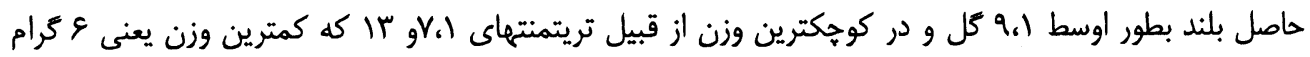

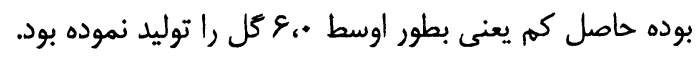

جدول \: تاثيرفاصله كشت يياز زعفران بالاى حاصل زعفران در يك جريب در هر دو محل(از تاريخ وعقرب الى لى (

\begin{tabular}{|c|c|c|c|c|}
\hline \multirow{3}{*}{ اوسط فاصله درهر محل } & \multicolumn{3}{|c|}{ فاصله كشت زعفران به سانتىمتر } & \multirow{3}{*}{ محل تجربه } \\
\hline & 10 & 1. & $\Delta$ & \\
\hline & \multicolumn{3}{|c|}{ حاصل زعفران در فى جريت به كرام } & \\
\hline VEAT & جه & 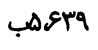 & alfirsa & كابل \\
\hline PETE & 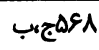 & (1. & (llf.r.. & ميدان \\
\hline SEYA & جYASE & (FTA & & اوسط محل \\
\hline
\end{tabular}

كوجكترين تفاوت(LSD): •هA 


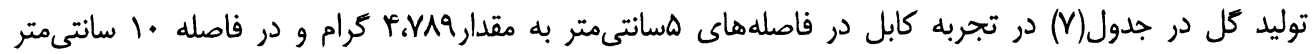

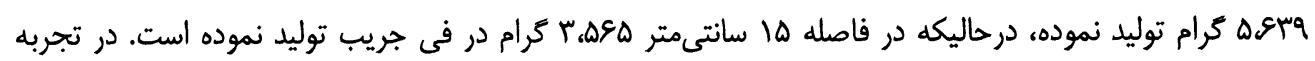

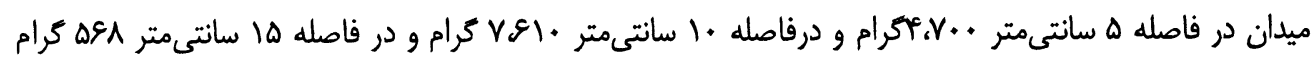

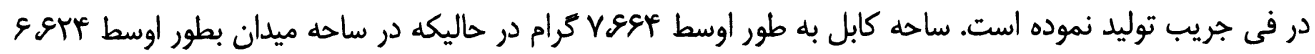

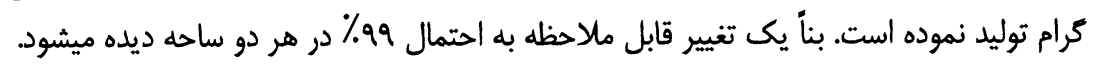
جدولمن تاثيروزن يياز زعفران بالاى حاصل زعفران در يك جريب در هر دو محل(از تاريخ وعقرب الى مץعقرب)

\begin{tabular}{|c|c|c|c|c|c|c|c|}
\hline \multirow{3}{*}{ محل وسط وزن هر دو } & \multicolumn{6}{|c|}{ بياز زعفران نظر به وزن به(كرام) } & \multirow[t]{3}{*}{ محل تجربه } \\
\hline & 11 & 1. & 9 & $\wedge$ & $\checkmark$ & 8 & \\
\hline & \multicolumn{6}{|c|}{ حاصل زعفران در يك جريب به(كرام) } & \\
\hline V.77ะ & ف & 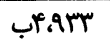 & ( & S IFAT & sijfiffq & 1.rov & كابل \\
\hline E.TY7 & |r|الف & ( ) & جه\&\& & shifra & 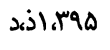 & (T) & 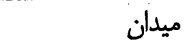 \\
\hline $7.7 \varepsilon 0$ & $9.1+98$ & r.qY. & A.TrA & $\varepsilon 71$ & r.ETr & r.TER & اوسط هر دو محل \\
\hline
\end{tabular}

كوجكترين تفاوت(LSD): PAD)

توليد گل در جدول(1) در تجربه كابل نشان ميدهد كه در وزنهاى

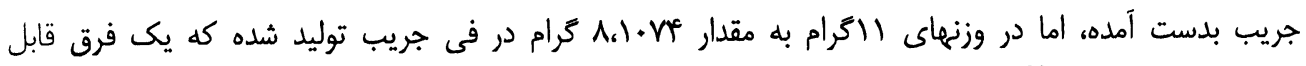

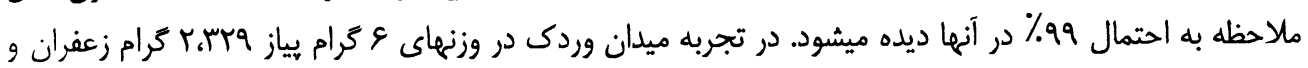

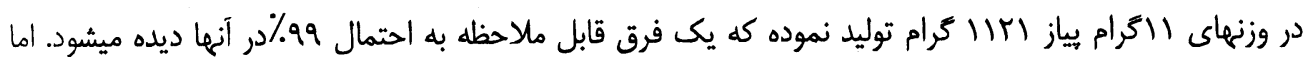

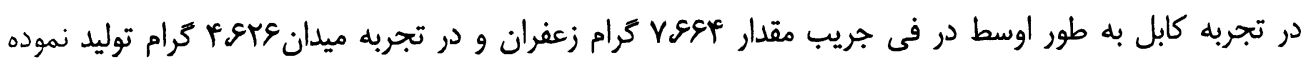

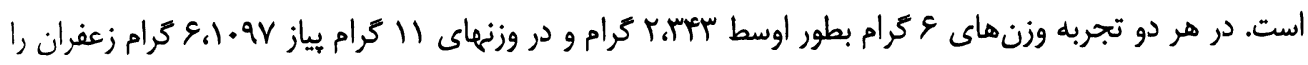

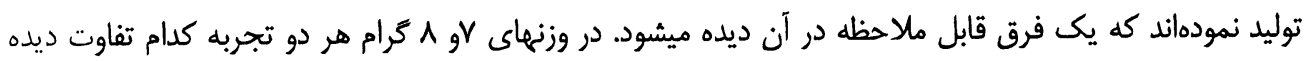
نشده است. جدولج: حاصل زعفران در فى جريب در هر دو تجربه كابل و ميدان وردك:

\begin{tabular}{|c|c|c|c|}
\hline اوسط حاصل در كابل وميدان & تجربه ميدان وردى حاصل در فى جريب در & تجربه كابل حاصل در فى جريب در & ترتمنت \\
\hline D.rfpe & (الف Vif If & ض، brf & 1 \\
\hline ( & (الف Far & ص، صهQQ & $r$ \\
\hline 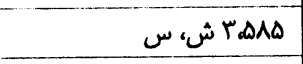 & T rofr & س س מ & $r$ \\
\hline 7EV & 每 Y & ل & $p$ \\
\hline
\end{tabular}




\begin{tabular}{|c|c|c|c|}
\hline & V.99Y الف & ||r| & $\Delta$ \\
\hline rYrV الف & هم1I الف & qצq الف & 8 \\
\hline 1+r+r ق، ف & צ.r الف & IاI ق، ظ & v \\
\hline brarar & هیr"r الف & b، f.. $^{\prime}$ & $\wedge$ \\
\hline b، b، & هף"זr الف & b، b.fla & 9 \\
\hline ;V.777 & r YosAr & j.jV.VA. & 1. \\
\hline ذ ذ د AVq & هوم الف & $2 M 9$ & 11 \\
\hline
\end{tabular}

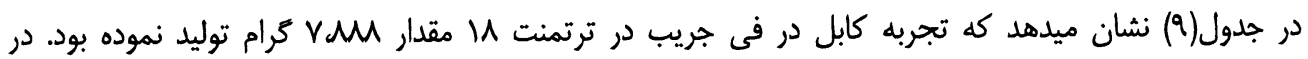

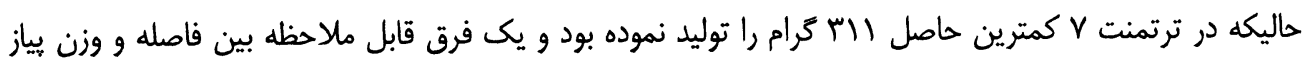

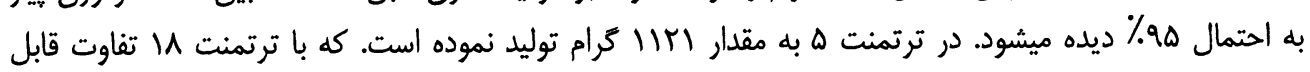

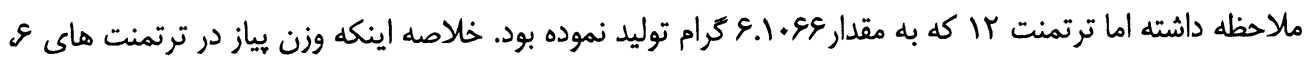

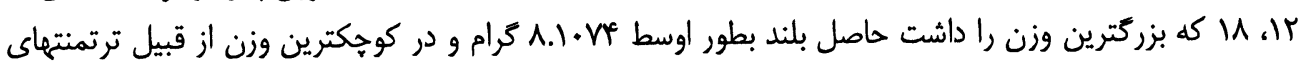

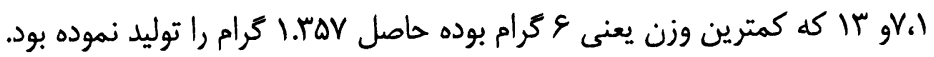

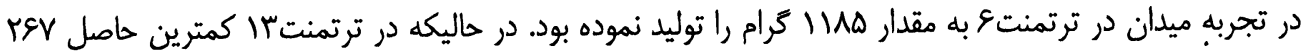
كرام را توليد نموده بود و كدام فرق قابل ملاحظه در بين تركيب فاصله و وزت وزن بيد بياز ديده نمى شودد. خلاصه اينكه

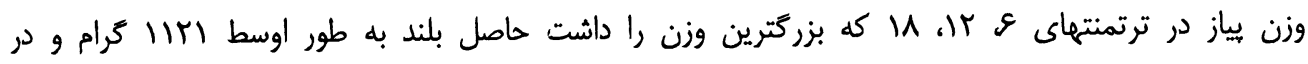

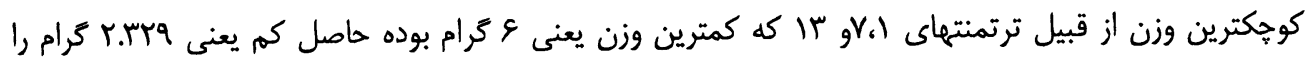
توليد نموده بود.

اما در اوسط هر دو محل كابل و ميدان وردك نيز تفاوت قابل ملاحظه به احتمال 99٪ ديده ميشود. در ترتمنت ع و

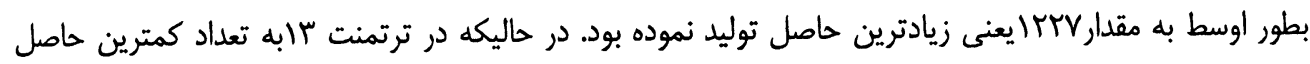

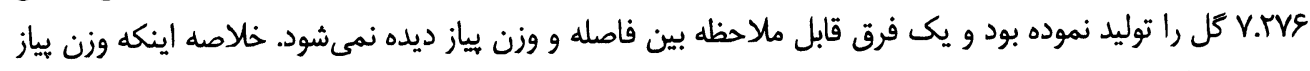

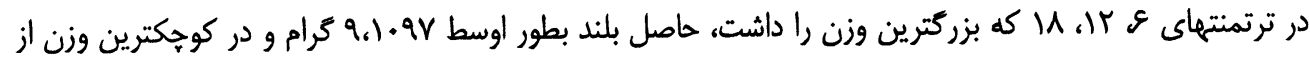

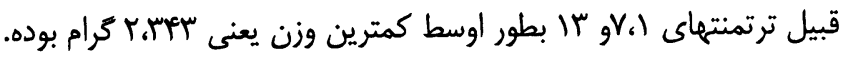

نتيجه:

توليد كلها در تجربه كابل و تجربه ميدان به اساس وزنهاى مختلف يياز زعفران تفاوت قابل ملاحظه دارد.

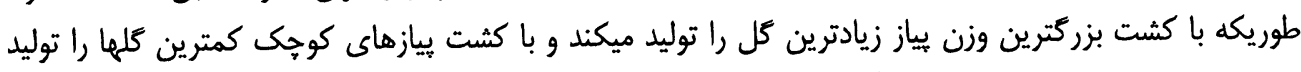

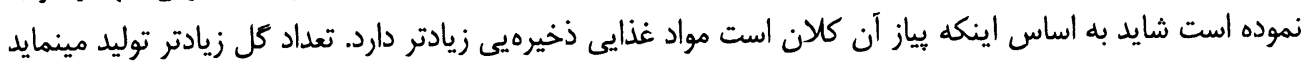
از اينكه در مرحله اول بيازهاى آن كل توليد مينمايد و برى ندارد مواد غذايى توليد كرده نمىتواند. بناً از مواد مواد 
غذايى ذخيره وى استفاده مينمايد و همجنان فاصله كشت بين بيازها در توليد كل جندان تانئ تاثير نداشته است شايد

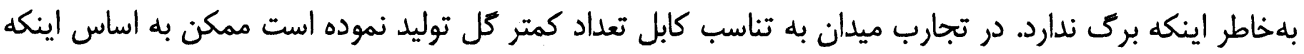

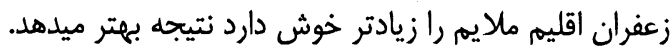

Lَآخذ:

$$
\begin{aligned}
& \text { 1- افضلى، خ.م،، FAFIا، زعفران. مطبعه نعمانى سينما بهارستان، صזr. } \\
& \text { r- بهنا، م.، • لَrا، زراعت زعفران. انتشارات دانشكاه تهران. }
\end{aligned}
$$

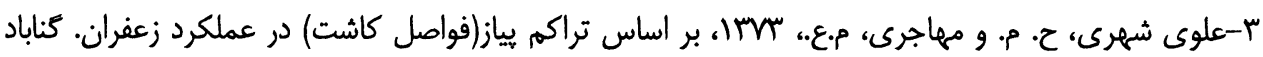
(1)

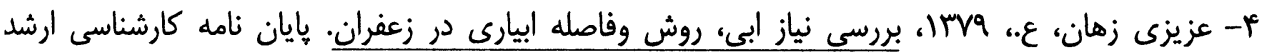

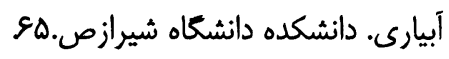

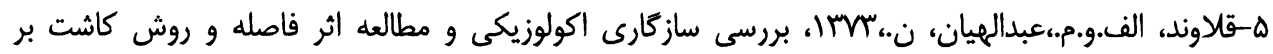

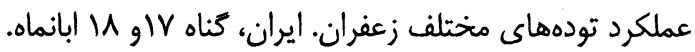
צ- لطيفى، ن. ك. مشايخى، هVI ا،.بررسى اثر وزن بته بر كل دهى زعفران.

جكيده مقالات جهارمين كنكره علوم زراعت و اصلاح نباتات ايران. دانشكده كشاورزى دانشكاه صنعتى

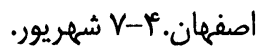

7-Ait-aubahou, A., And M. El-otmani, 1999، saffron cultivation in Morocco.

Harwood Academic pub. Amsterdam, 154pp.

8. Dacaar, 1370، Saffron Manual for Afghanistan. DACAAR HeartProvincial.

9. Dacaar, 2007، Information about saffron planting, maintenance, harvesting and processing. Paikob-e- Naswar, Wazirabad, Kabul, Afghanista,16p. 


\section{تاثير كاهش رطوبت خاك بالاى توليد \\ مواد خشك و حاصل كندم}

مقدمد:

كندم نبات مهم غذايى و موسم سرد و يكى از نبات عمده افغانستان بوده است. در بعضى مناطق منابع أب،

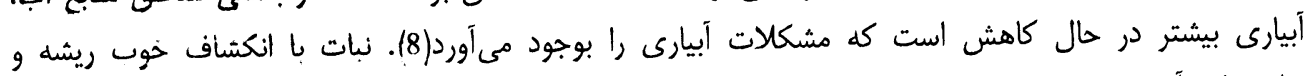

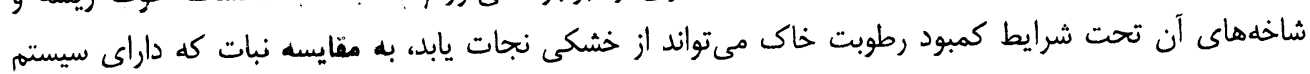

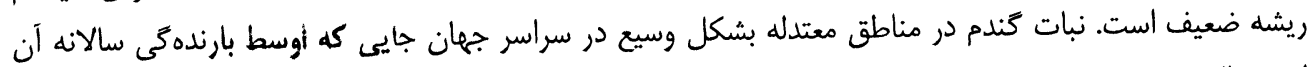

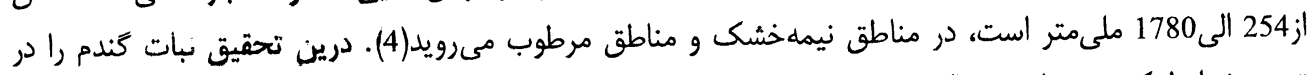

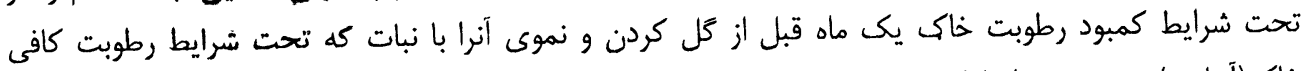

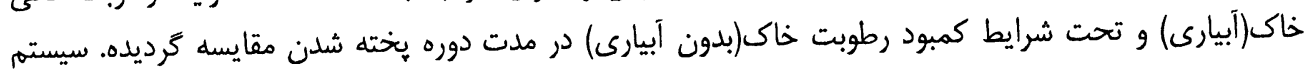

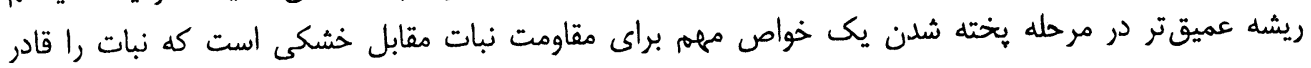

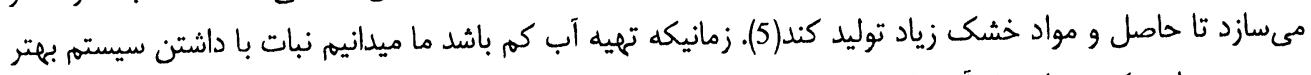

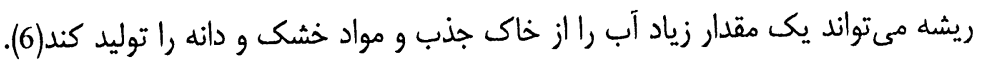

موادو روش تحقيق: :

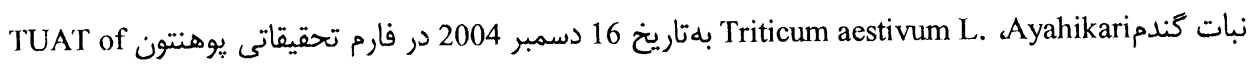

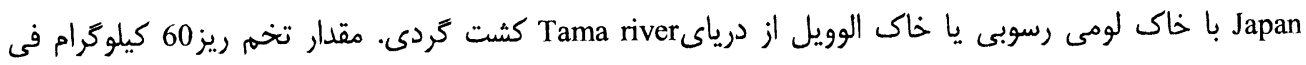

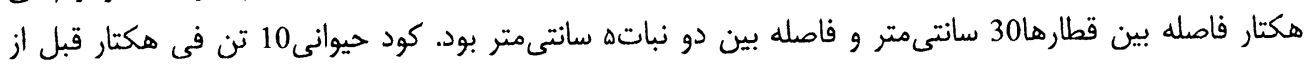
كشت استفاده شد و به تاريخ7 دسمبر طاقه كارى صورت گرفت، كود كيمياوى

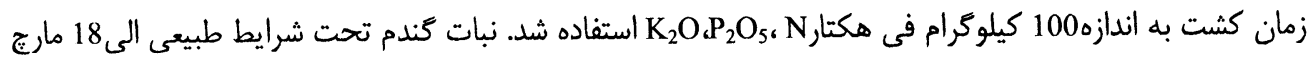
رويانيده شد.20 إيريل نبات كل كرد و به تاريخ 14 جون كندم جمع آورى كرئ كرديد. 2-تريتمنت رطوبت خاك:

Wو تريتمنت به تاريخ 8 مارج شروع شد نبات كندم تحت شرايط مختلف روئيد يعنى(Dيلات بدون آبيارى 


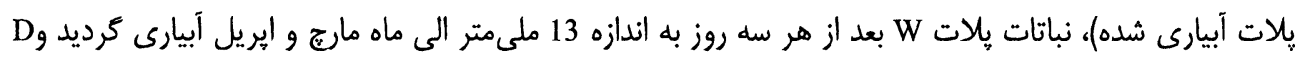

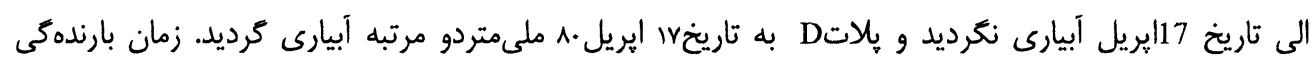

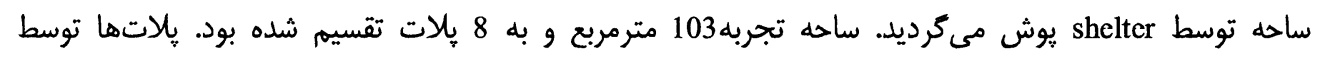

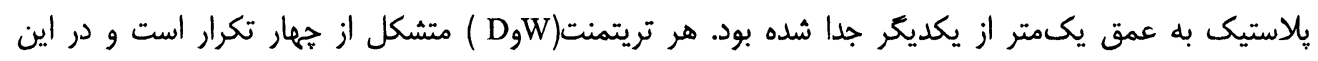

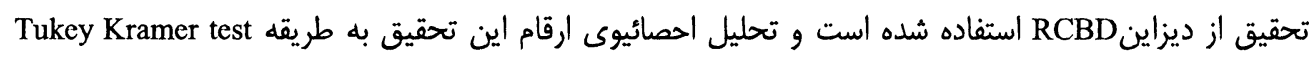
محاسبه شده است.

$$
\text { 3-اندازه كيـى ذخيسه آب بـر: }
$$

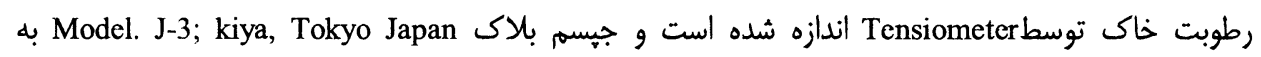

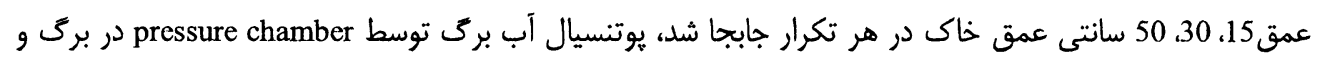
ساقه اصلى تحت شعاع مستقيم آفتاب اندازهخيرى شد. 4-اندازه كيسى مواد خشك و ساحه بـر: به طول 50 سانتىمتر از هر قطار به اساس اوسط ساقه نمونه گرفته شد براى اندازهگيرى مواد خشك. ابتدا

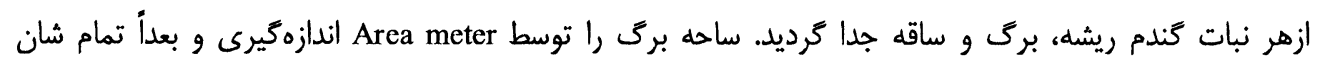
غرض معلوم كردن مواد خشك هر قسمت در داخل داش ventilated oven تحت 80 درجه سانتى گراد كذاشته شد و و بعد از سه روز اندازهزيرى صورت مورت مرفت. 5-اندازميسى حاصل دانه و اجنا حاصل: از هر تكرار به اندازه 0.9 مترمربع نبات گتندم غرض معلوم نمودن حاصل بر فى واحد ساحه درو گرديد. گرفتن سميل از هر قطار به طول 50 سانتىمتر نمونه كرفته شد.

نتايج تحقيق:

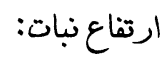

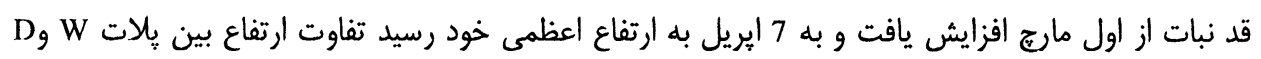

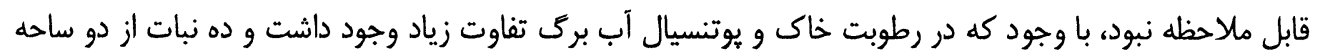

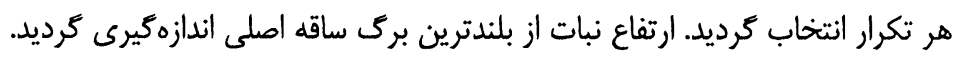




\begin{tabular}{|c|c|c|}
\hline \multirow[b]{2}{*}{ تار بخ اندازه كَبري } & قد نبات به سانتي منر & \multirow[b]{2}{*}{ يلات أبياري نشده (D) } \\
\hline & يلات أبياري شده (W) & \\
\hline 7-Dec & 8 & 8 \\
\hline 14-Dec & 9.5 & 9.2 \\
\hline 12-Dec & 10 & 10.1 \\
\hline 28-Dec & 10.7 & 10.6 \\
\hline 11-Jan & 11.5 & 11.8 \\
\hline 18-Jan & 12.1 & 12.2 \\
\hline 25-Jan & 12.8 & 12.8 \\
\hline 1-Feb & 13.6 & 13.5 \\
\hline 10-Feb & 13.9 & 13.7 \\
\hline 17-Feb & 15.3 & 14.8 \\
\hline 24-Feb & 16.3 & 15.8 \\
\hline 3-Mar & 18.1 & 17.7 \\
\hline 11-Mar & 22.4 & 21.9 \\
\hline 17-Mar & 22.4 & 21.9 \\
\hline 24-Mar & 37.1 & 38.1 \\
\hline 31-Mar & 47.3 & 47.6 \\
\hline 7-Apr & 62.4 & 63 \\
\hline
\end{tabular}

جدول(1): تاثير رطوبت خاى بالاى قد نبات در جريان فصل نمويى جلم

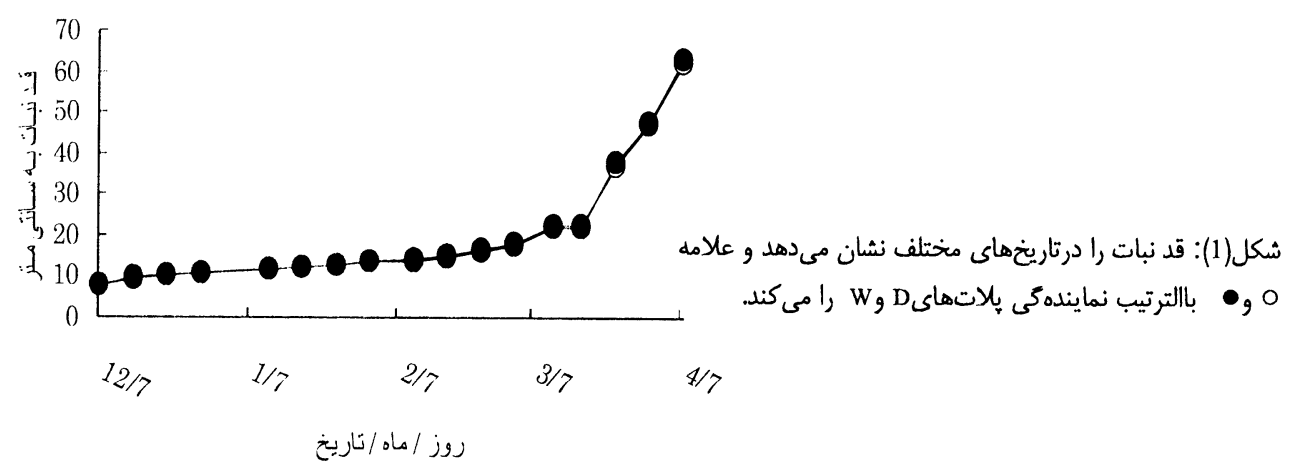

تعداد ساقه:

دراوسط تعداد ساقه در فى مترمربع بين W و ملات كدام تفاوت قابل ملاحظه ديده نشد. تعداد ساقه تا 17 واف

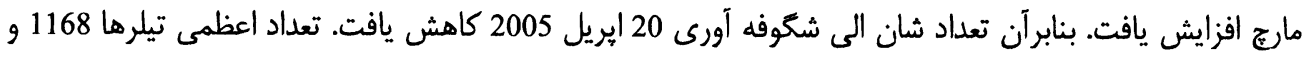

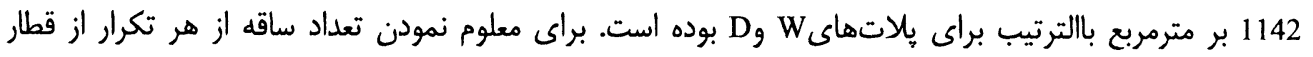
بطول 50 متر شمارش شد. جدول(2): تاثير رطوبت خاك بالاى تعداد ساقه در جريان فصل نمويى 


\begin{tabular}{|c|c|c|}
\hline \multirow[t]{2}{*}{ تاريخ انداز ه كيرى } & \multicolumn{2}{|c|}{ تعداد ساقه نبات } \\
\hline & 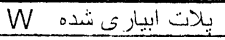 & Dبن ابياري نشده D \\
\hline 7-Dec & 127 & 130 \\
\hline 14-Dec & 127 & 130 \\
\hline 21-Dec & 213 & 204 \\
\hline 28-Dec & 271 & 270 \\
\hline 11-Jan & 322 & 333 \\
\hline 18-Jan & 414 & 419 \\
\hline 25-Jan & 479 & 501 \\
\hline 1-Feb & 550 & 540 \\
\hline $10-\mathrm{Feb}$ & 705 & 668 \\
\hline 17-Feb & 848 & 786 \\
\hline 24-Feb & 895 & 823 \\
\hline 3-Mar & 972 & 879 \\
\hline 11-Mar & 1106 & 1044 \\
\hline 17-Mar & 1168 & 1143 \\
\hline 24-Mar & 1107 & 975 \\
\hline 31-Mar & 939 & 895 \\
\hline 7-Apr & 781 & 771 \\
\hline
\end{tabular}

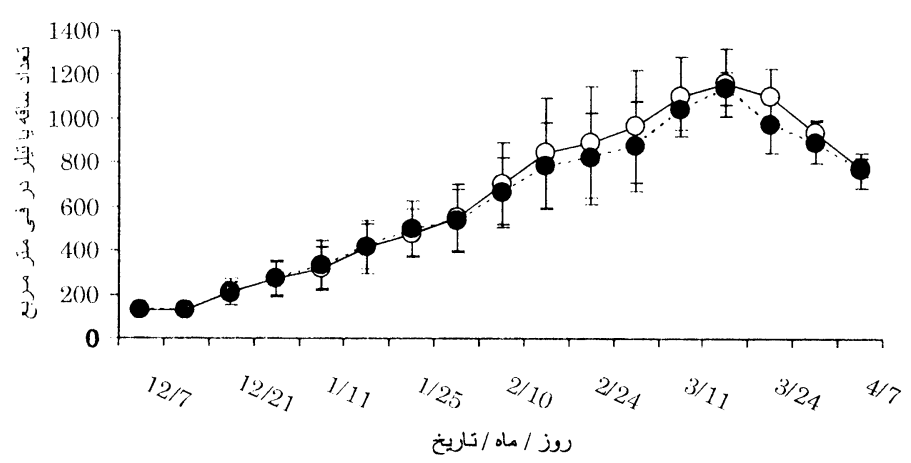

شكل(2): تعد اد ساقه را درفى متر مربع در تاريخهاى مختلف تحت نشان مىدهد

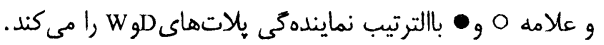

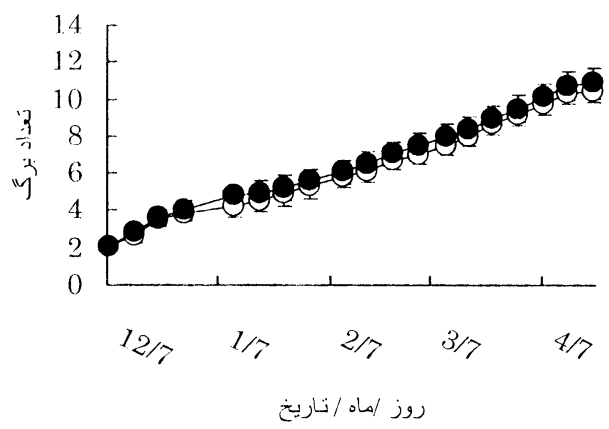

شكل(3) : تعداد برى را در تاريخ مختلف نشان مى دهد ,علامه ماله

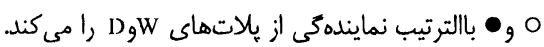

$$
\text { : تعداد. }
$$

با توجه به نموى برى، دريافت شد كه برگ نبات يلات W زود انكشافكرد نسبت به برك نبات D,

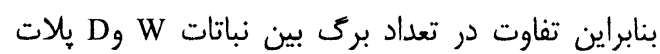
ملاحظه نشد. ينج ساقه انتخاب و اندازهكيرى شد و يك ليك هفته بعد از كشت به مدت يكى ماه الى 7 ايريل 2004 اندازهكيرى كرديد. 
براى اندازهيرى رطوبت آب خاك از انواع مختلف سامان آلات مثل Tensiometer و Gypsum block استفاده

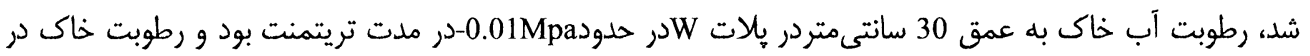

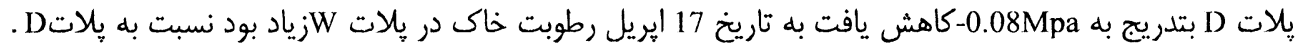
Dypsum block

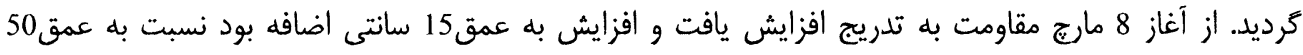

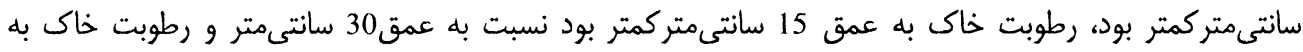

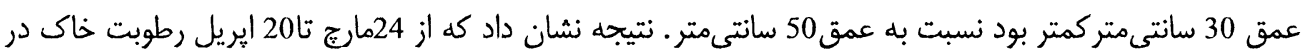

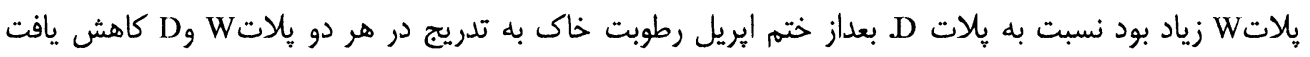
تفاوت دقيق مشاهده نشد.
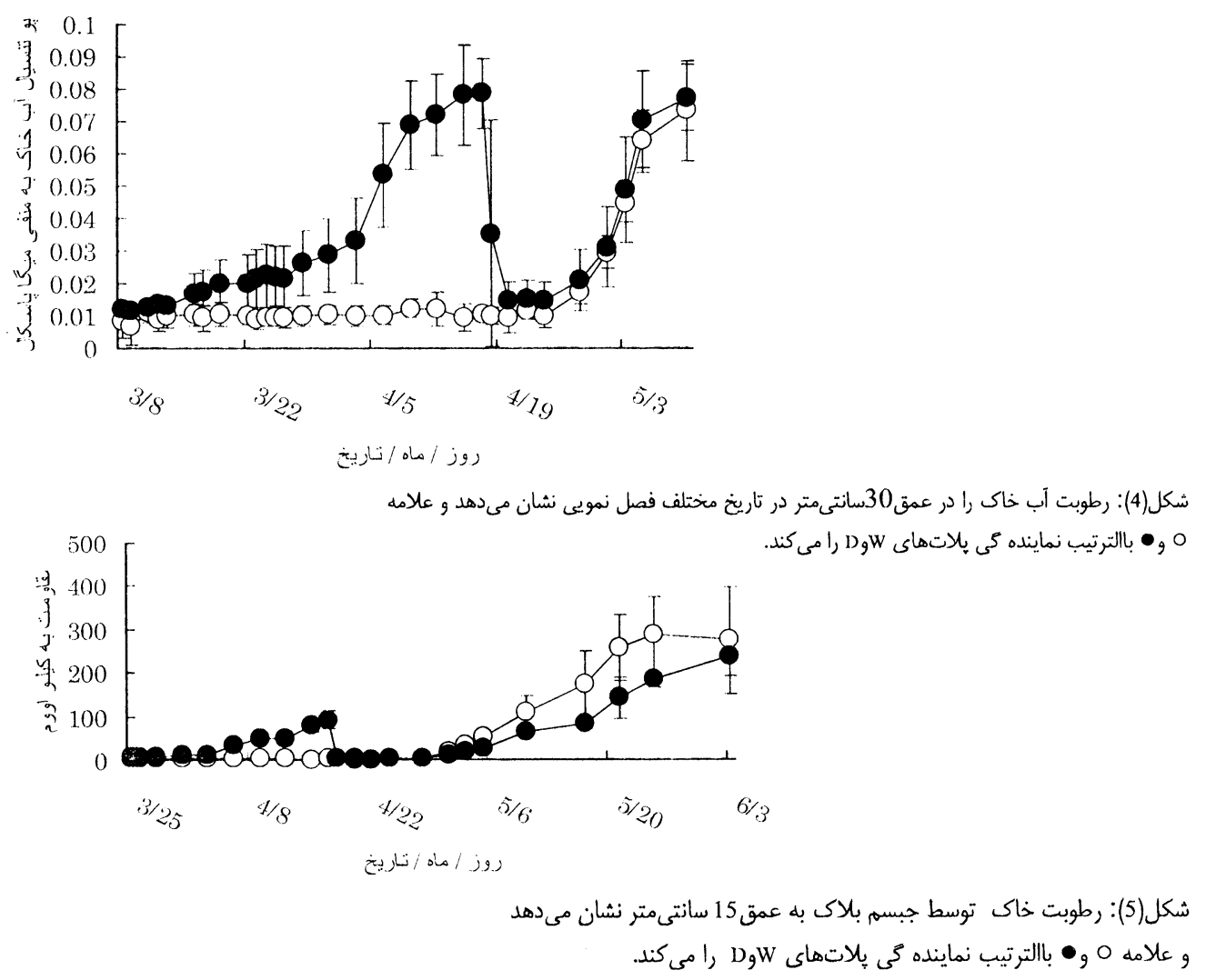


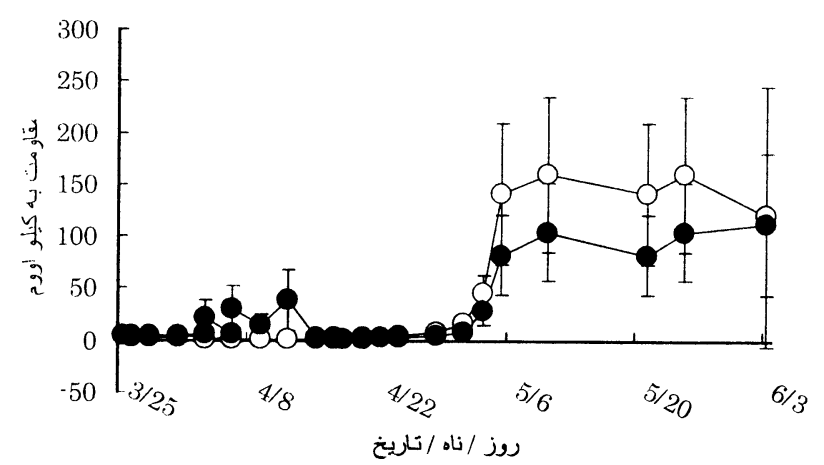

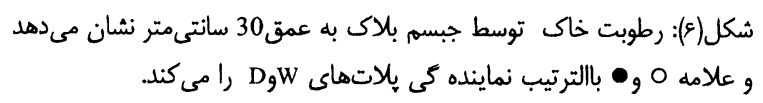

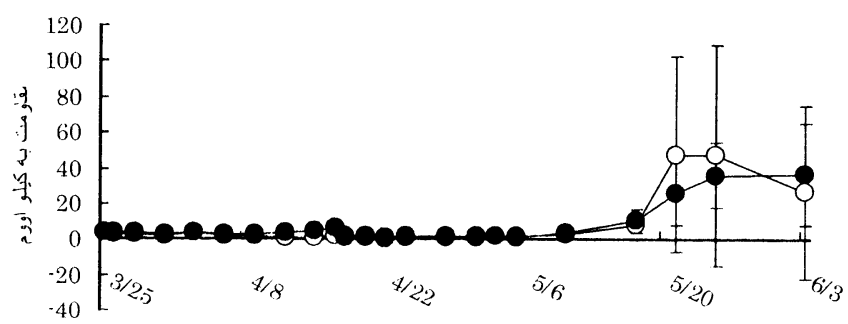

روز/ماه/تلايخ

شكل(7): رطوبت خاك توسط جبسم بلاكى به عمق 50 سانتىمتر نشان مىدهد

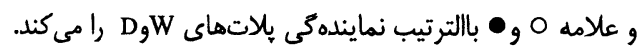

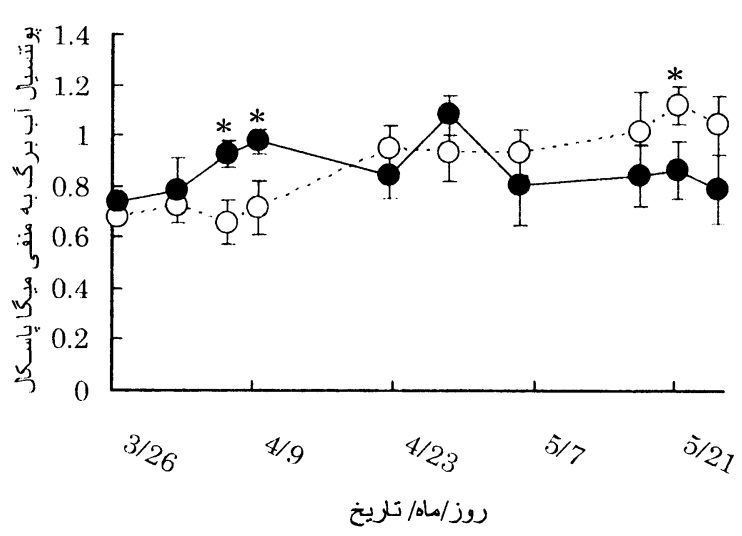

شكل(8): يوتنسيال ذخيره آب برك را درجريان فصل نمويى نشان مى دهد علامه

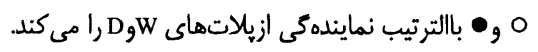

بوتنسيال آب برگ

اين تغيير در زمان تريتمنت بيش از كل كردن است. يوتنسيال

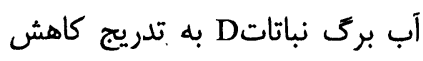
يافت و كمتر است نسبت به نباتات W يلات و در آن تفاوت قدابل

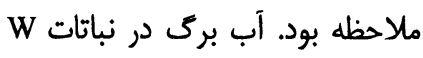

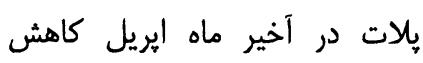
يافت اما از يوتنسيال آب برت آلات نباتات W به تدريج كاهش يافت جون در نتيجه يوتنسيال آب نباتات

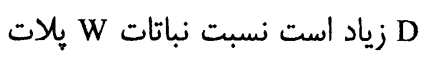




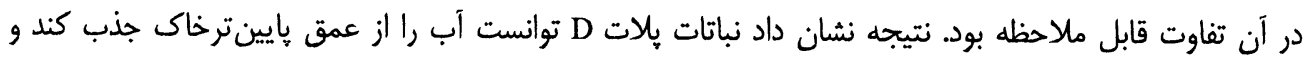

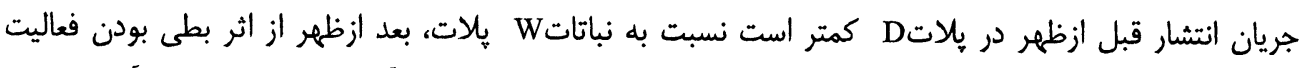

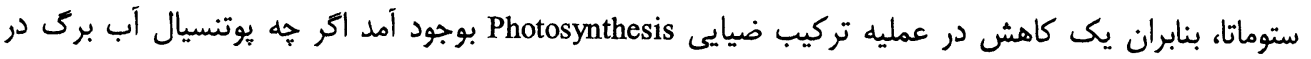

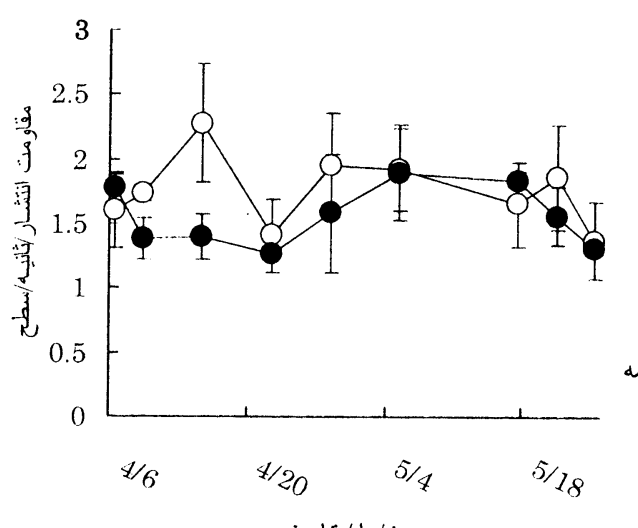

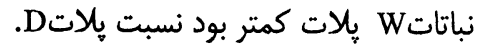

روز/ماه/تناريخ

وزن خشك:

در جريان فصل نمويى سه مرتبه نمونه گرفته شده است. در وزن خشك قسمت بالايى نباتات D, W درو 9 مارج

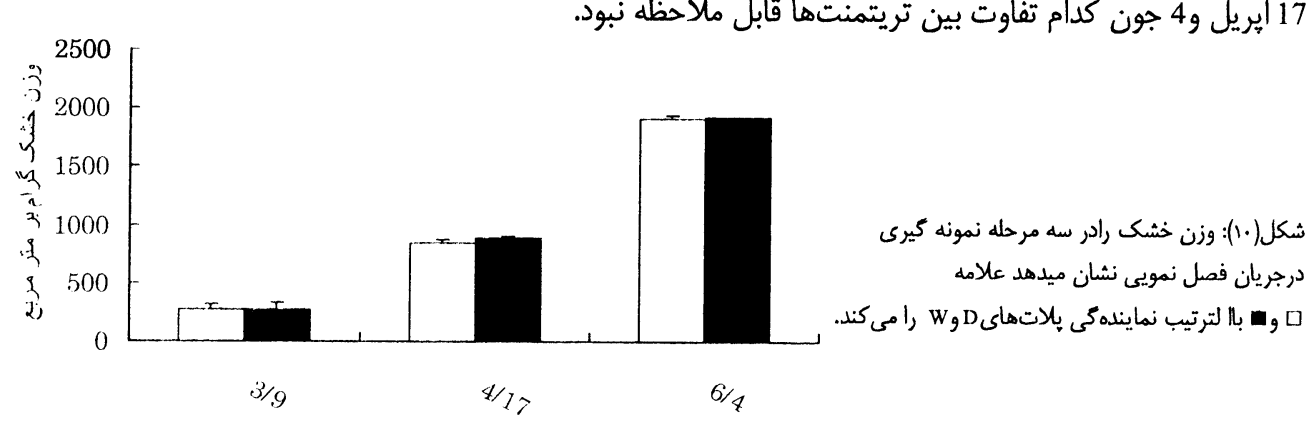

روز / ماه/ تلايخ

اندازه نمو، اندازه جذب خالص و ثثاخص ساحه بـى:

(Crop growth rate, Net assimilation rate, Lẹaf area index)

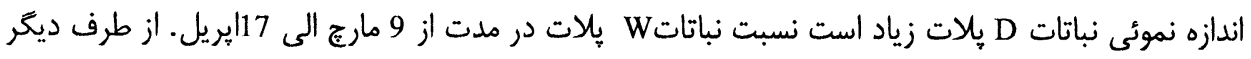

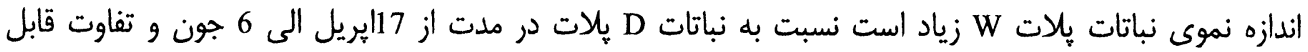

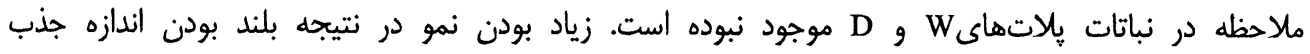

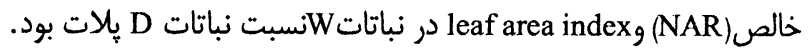




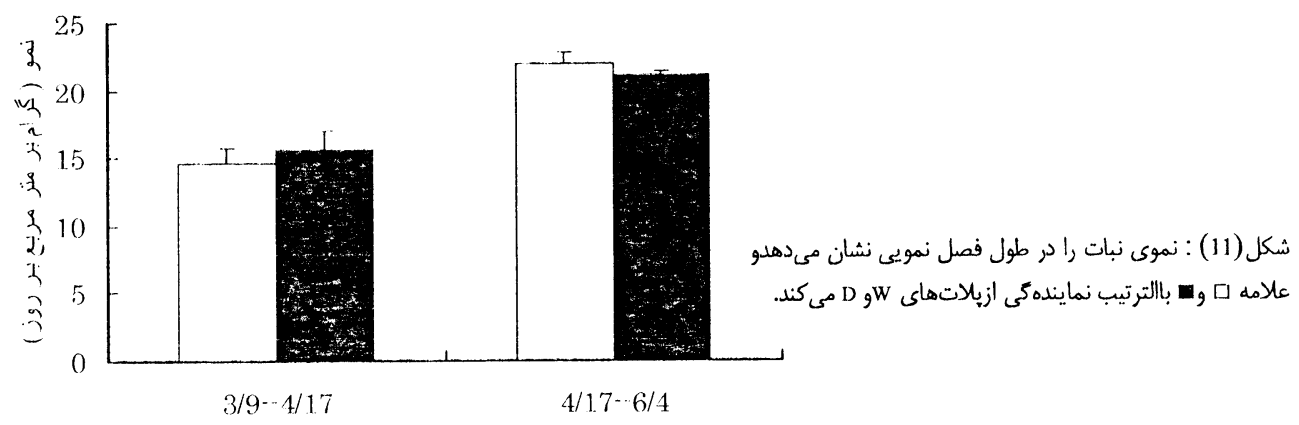

روز /ماه /تاريخ

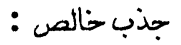

جذب خالص NAR نبات گندم به وسيله رطوبت خاى تحت تاثير قرار گرفت و اندازه جذب خالص نباتات

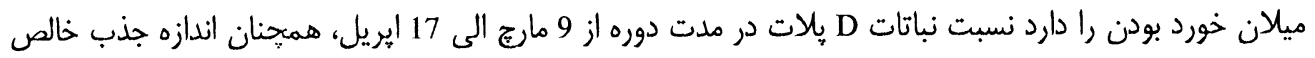

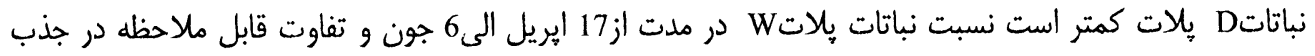

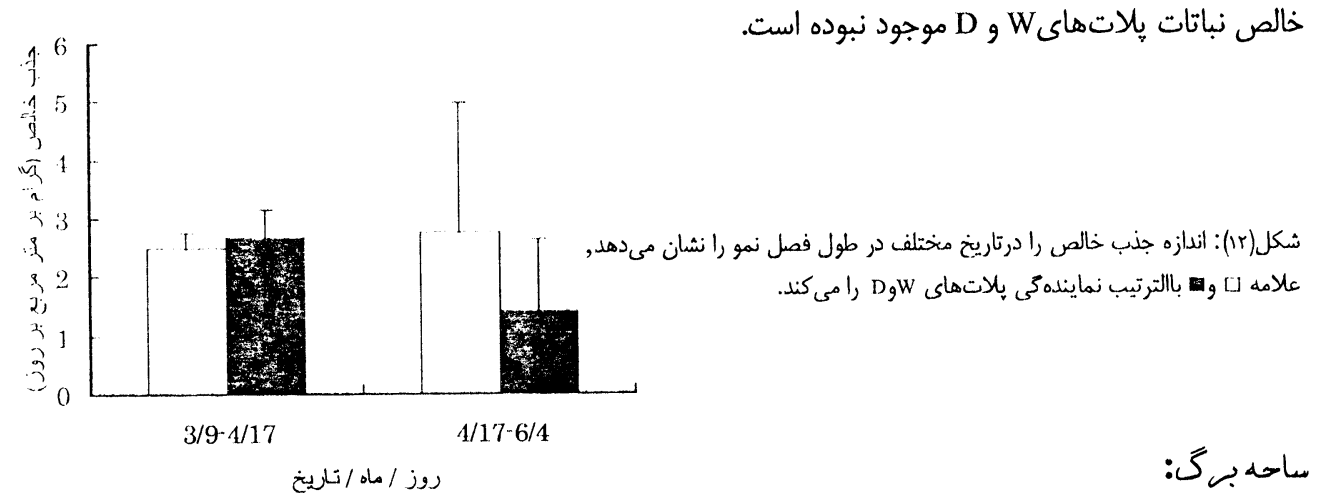
در اينجا تفاوت قابل ملاحظه در شاخص ساحه برك بين بلاتها قبل از كل آورى وجود ندارد. ساحه برى در

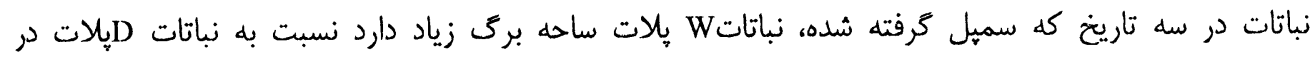

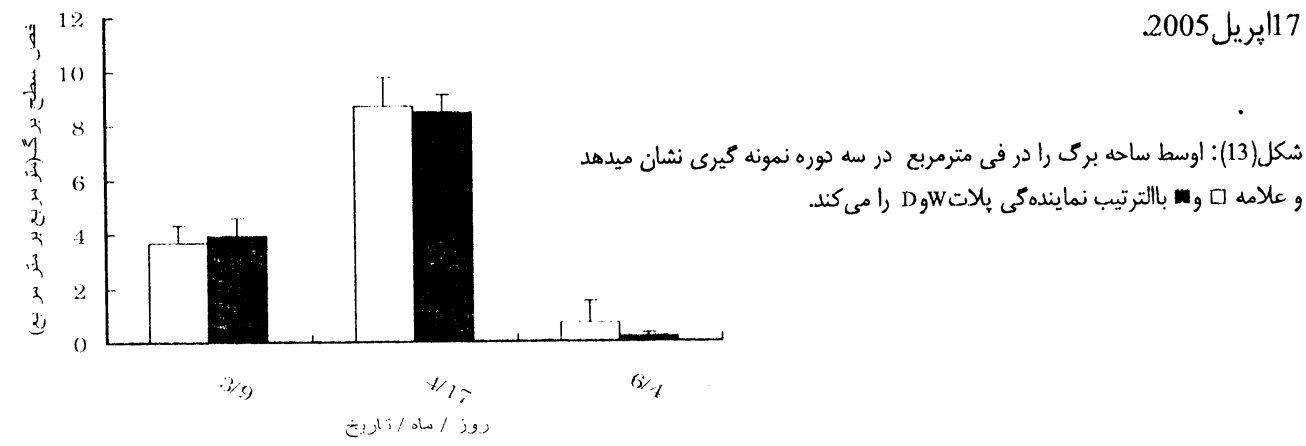


حاصل درD يلات 5 فيصد بيشتر بوده است نسبت بلات W ، شايد بخاطرداشتن تعداد زياد دانه و وزن دانه،

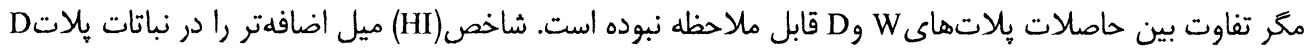

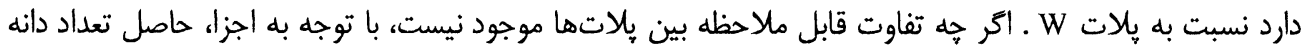

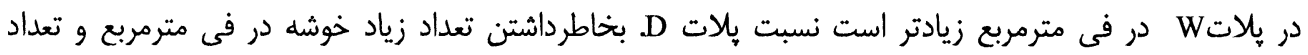
خوشجه در خوشه. جدول(1) حاصل و اجزاى حاصل را نشان مىدهد.

\begin{tabular}{|c|c|c|c|c|c|c|c|c|}
\hline 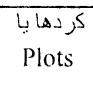 & تعداد خونشه بر & 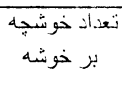 & تعدشاد دانه بر & تعدرد دانه بر & وزن به كر ام دانه & كتر كامل دانه & وزن خشرمك كر ام & حشاصل دانه بر وزن \\
\hline $\begin{array}{c}\text { آبيارى شند. } \\
\text { W }\end{array}$ & $589.4 \pm 3.3$ & $13.6 \pm 0.5$ & $1.9 \pm 0.1$ & $15675 \pm 438$ & $43.1 \pm 0.7$ & $771.9 \pm 21.9$ & $1845.34 \pm 46.2$ & $40.7 \pm 0.9$ \\
\hline بيارى نشده D & $592.4 \pm 22.8$ & $13.32 \pm 0.1$ & $1.8 \pm 0.1$ & $14638 \pm 574$ & $43.1 \pm 0.6$ & $812.5 \pm 23.0$ & $1789.9 \pm 28.8$ & $41.5 \pm 1.9$ \\
\hline
\end{tabular}

از هر تكرار به اندازه 0.9متر مربع ساحه نبات غرض تعيين نمودن حاصل فى واحد ساحه جمعآورى كرديد وزن با رطوبت12.5٪.

مناقشه:

نباتات يلاتD مواد خشك اضافه توليد كرد. اكرجه يك ماه قبل از كشيدن خوشه نسبت به نباتات آبيارى

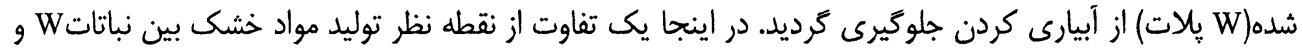

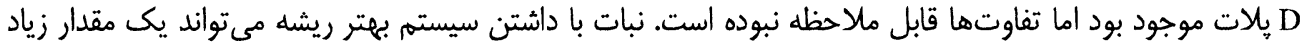

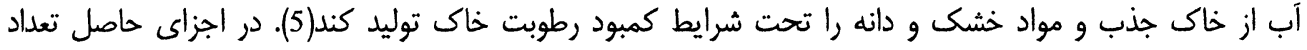

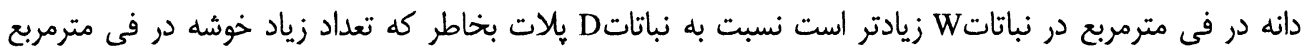

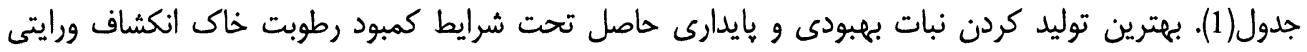

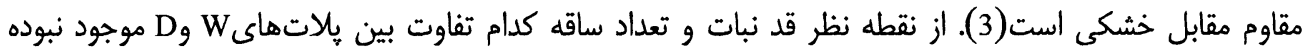

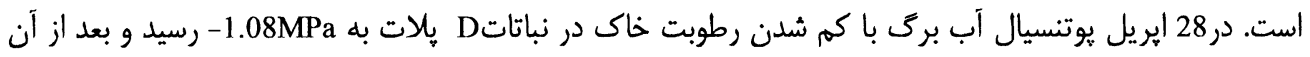

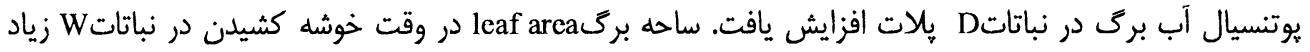

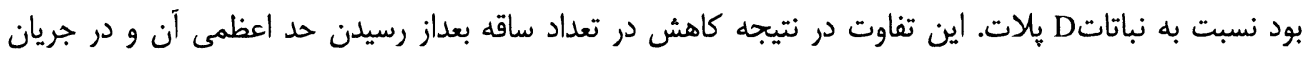

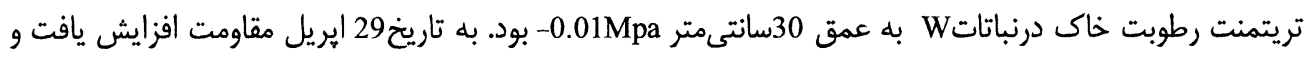

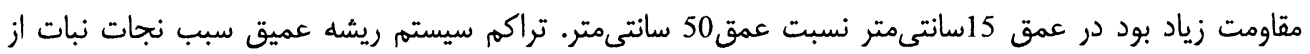

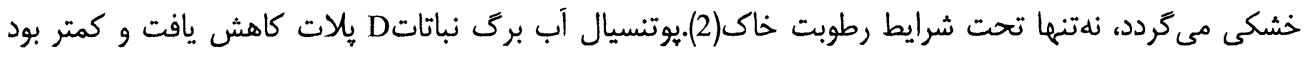

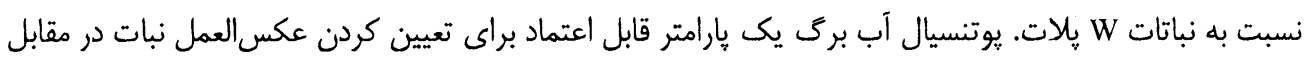


خشكى است(7). به تاريخ 28 ايريل در مرحله خوشه كشيدن در نباتاتWلاتلات توسعd برى يا leaf expansion و و

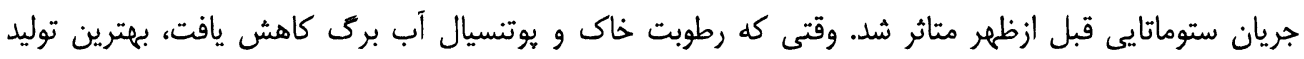
كردن نبات، بهبودى و يايدارى حاصل تحت شرايط كمبود رطوبت خاك انكشاف ورايتى مقاوم مقابل خشكى است.

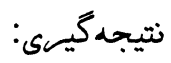

اگر جه نباتات D-plot يك ماه ييش از خوشه كشيدن از آبيارى جلوكيرى كرديد، يوتنسيال آب بركى به

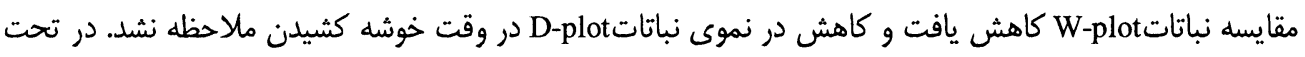

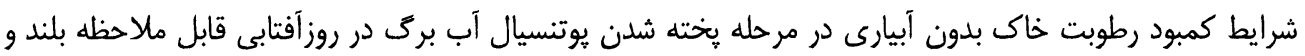

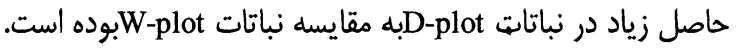

\section{References:}

1-Akmal, M. and Hirasawa, T. 2004. Growth responses of seminal roots of wheat seedlings to a reduction in the water potential of vermiculite. Plant Soil 267: 319-328.

2-Kramer, P. J. 1983. Water relations of plants. Academic Press, Inc, New York. Pages 5895.

3-Magness, J.R., G.M. Markle, and C.C. Compton. 1971. Food and feed crops of the United States. Interregional Research Project IR-4, IR Bul. 1(Bul. 828 New Jersey Agr. Expt. Station.).

4-Martin, J.H., Waldren, R.P. and Stamp, D.L. 2006. Principles of Field Crop Production. Pearson Prentice Hall, Columbus.

5-Nakagami, K., T. Ookawa and T.Hirasawa 2004. Effects of a reduction in soil moisture from one month before flowering through ripening on dry matter production and ecophysiological characteristics of wheat plants. Plant Prod. Sci. 7(2):143-154.

6-Nakamura, E., T. Ookawa, K. Ishihara and T. Hirasawa 2003. Effects of soil moisture depletion for one month before flowering on dry matter production and ecophysiological characteristics of wheat plants in wet soil during grain filling. Plant Prod. Sci. 6(3):195205.

7-Siddique, M. R.B., Hamid, A., Islam,M. S. 1999. Drought stress effects on photosynthetic rate and leaf gas exchange of wheat. Bot. Bull. Acad. Sin. 40: 141-145.

8-National Research Council 1989. Alternative Agriculture. National Academy Press, Washington, D.C. 1-448. 


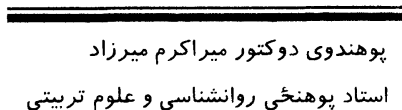

استاد يوهنحُى روانشناسى و علوم تربيتى

\section{نياز مندىهاى اساسى دوره \\ نوجوانى}

ح

نيازمندىهاى اساسى دوره نوجوانى كه به رشته تحرير در آورده شده انعكاس دهنده واقعيتهاى دوره نوجوانى

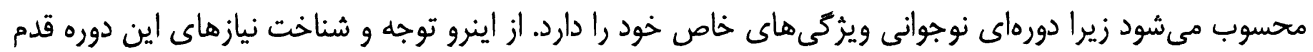

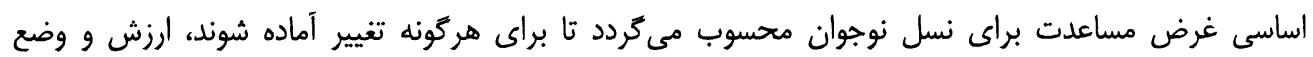

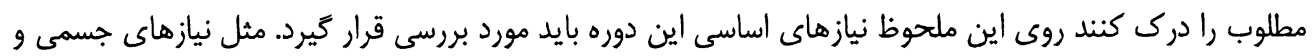

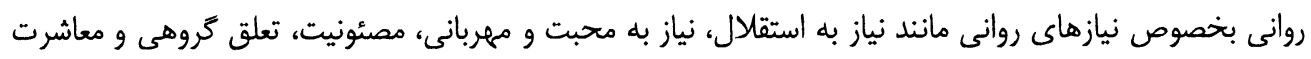

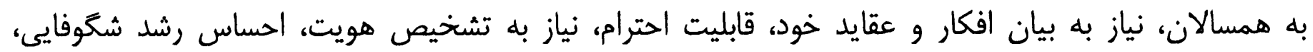

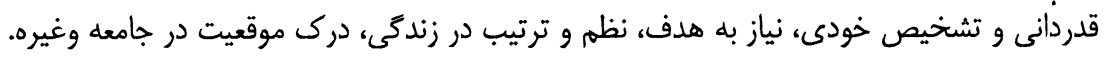
مفاهيه كليدى:- تشخيص نيازهاى اساسى دوره نوجوانى اهداف تربيتى، اصول روشها، محتوا و نتيجهذيرى مىباشد.

مقدمه:

با يايان يافتن دوره كودكى، فرد وارد مرحلهى مىشود كه شرايط آن با شرايط دوره قبلى كاملاً متفاوت است.

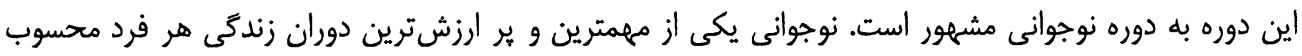

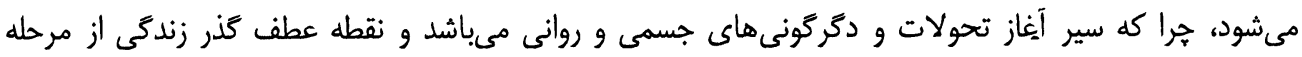

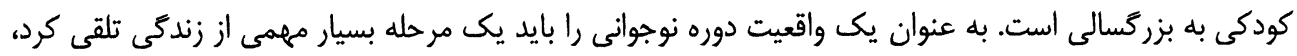

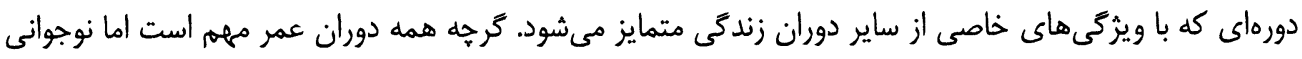

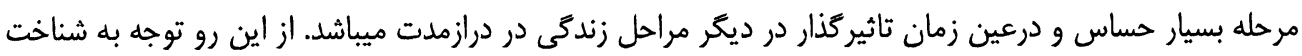

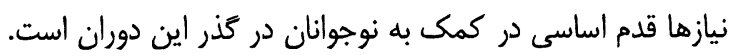

نوجوانان در اين دوره، شرايط، توقعات و نيازهاى تازهيى دارند كه نمى توان آنرا با دوره قبلى وى يكى دانست. به

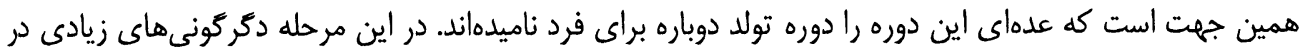

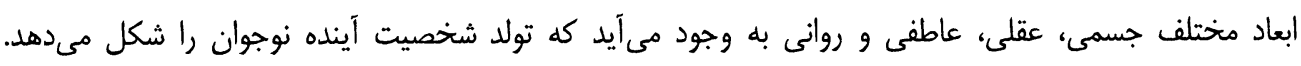

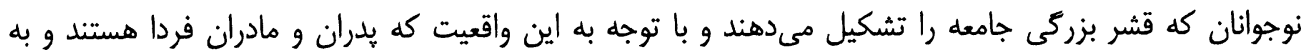


عنوان نيروى محر كه و آينده سازان جامعه محسوب مىشوند، قابل تأمل است تا با شناخت نيازها، نكرشها، ويز كيريها

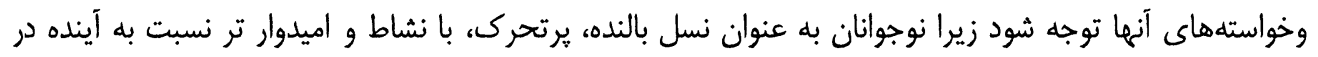

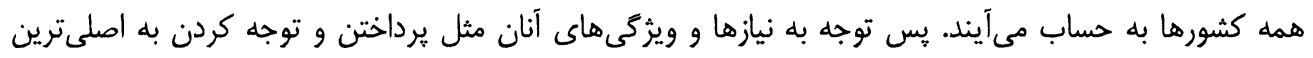

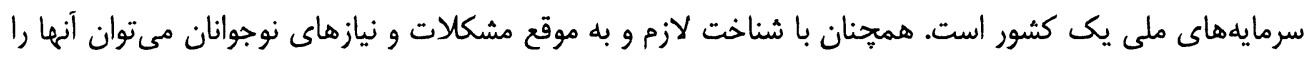

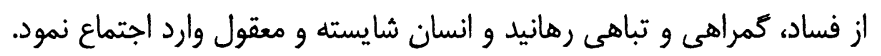

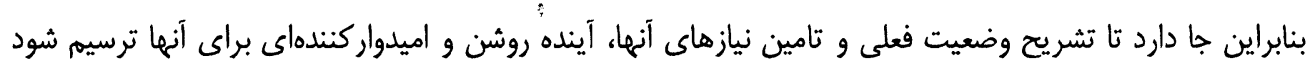

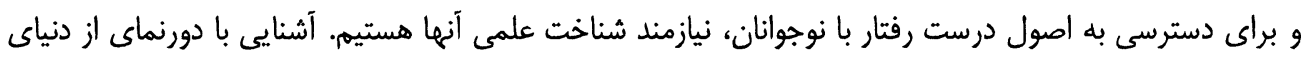

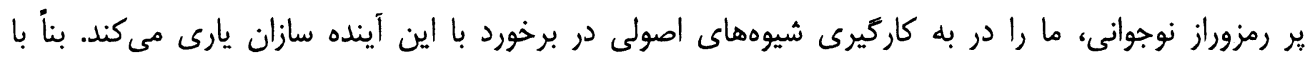

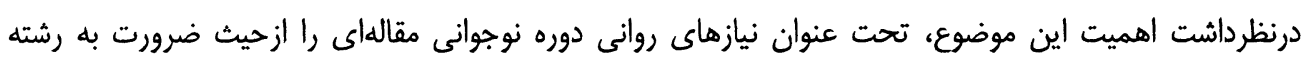
تحرير آوردمام.

\section{معنى ومنهومنياز:}

نياز در لغت به معناى احتياج، حاجت، ضرورت و فقدان است(ا:مNي). نياز حالتى است كه با احساس فقدان يا

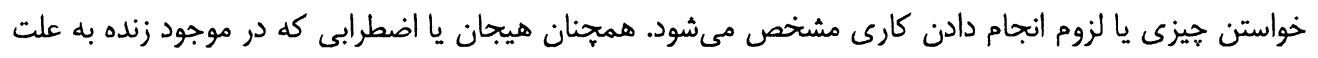

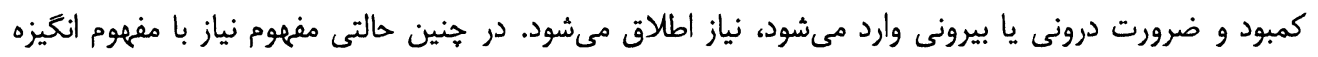

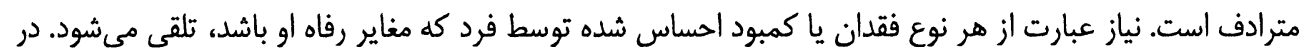

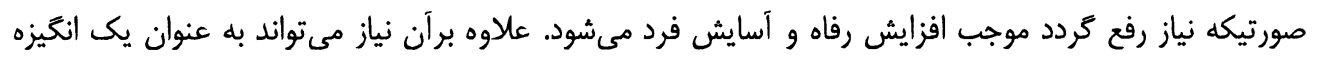

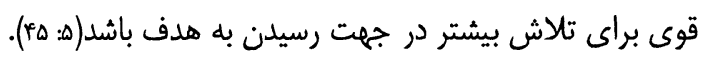

مفهوم نياز از جمله مفاهيمى است كه با معانى مختلفى به كار رفته است. از برداشتها و و تعارفى كه در دراك مورد نياز

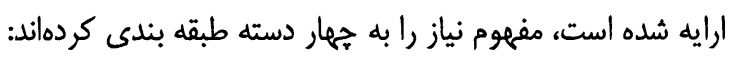
دسته اول- نياز به عنوان فاصله بين وضع موجود و وضع مطلوب است. يعنى نياز به موقعيتى دلالت دارد كه درآن وضعيت موجود با وضعيت مطلوب فاصله دارد و وضعيت مطلوب در بركيرنده ايدالها، ترجيحات، انتظارات و ادراكات مختلف درباره آنجه كه بايد باشد، است.

دسته دوز نياز به عنوان يك خواست يا ترجيح: در اين ديد5اه نظريات و عقايد افراد و كروههاى مختلف مدنظر

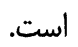

دسته سوز نياز به عنوان يك عيب يا نقصان: در اين برداشت نياز به عنوان يك نقصان و عيب يا نوعى كمبود به

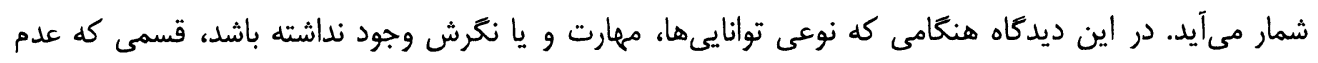

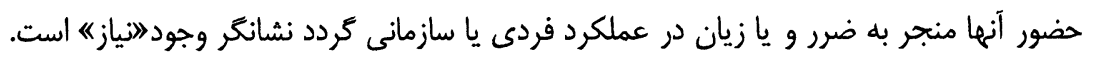


دسته جهارج برداشت تركيبى است: أنجه كه بين وضع موجود و وضع مطلوب قرار دارد و آنجه كه انتظارات،

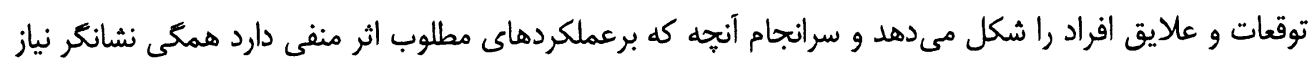
هستند(S:S).

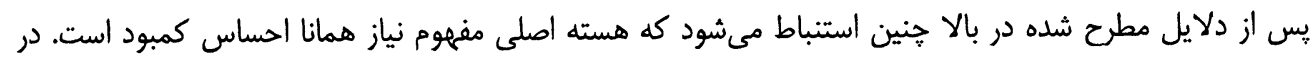

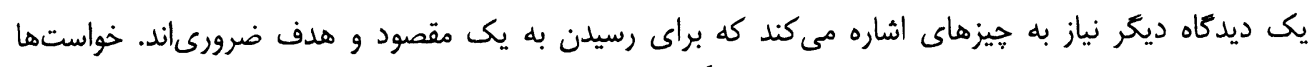

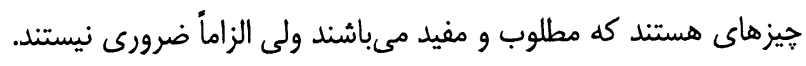
با توجه به مطالعات انجام شده، نيازها مى تواند ويثُى ها و خصوصيات ذيل را داشته باشد: • تمام مردم نيازهايى دارند.

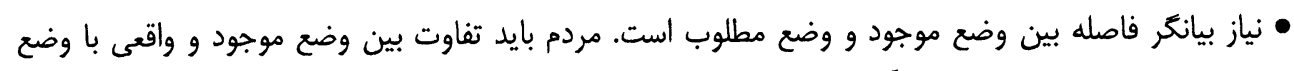

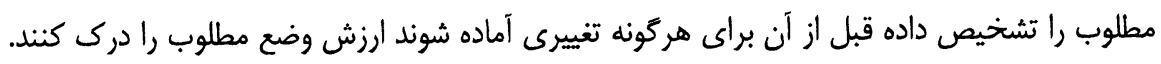
• نيازها مى تواند داراى ماهيت انفرادى باشند يا بين اعضاى گروهها مشتر بـ باشند. نيازها به مرور زمان تغيير مى كنند. • نيازهاى مردم با افزايش سن و ايجاد تغييرات اقتصادى و اجتماعى تغيير مى كند. • اهميت نسبى نيازها، متاثر از شرايط فزيكى، فرهنگى و اجتماعى است.

تعريف نوجوانى:

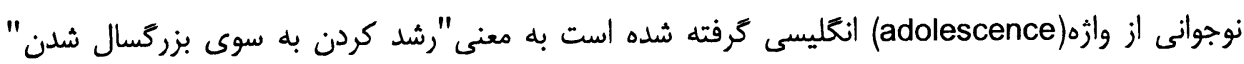

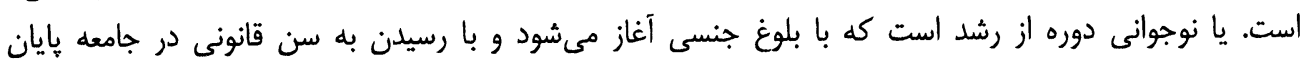

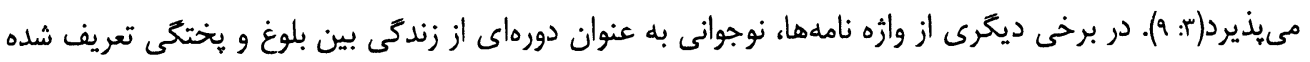

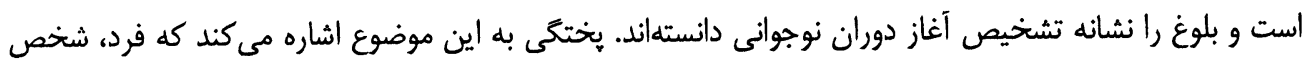

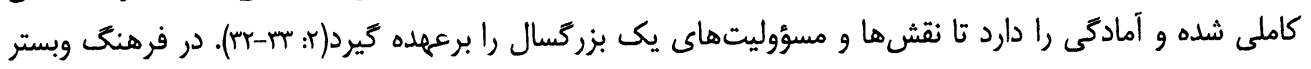

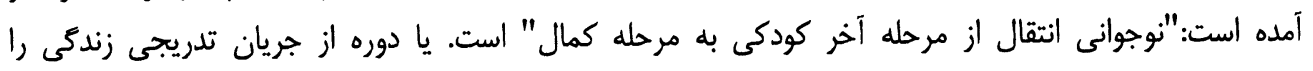

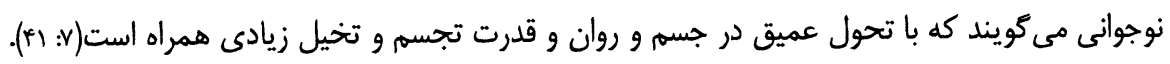

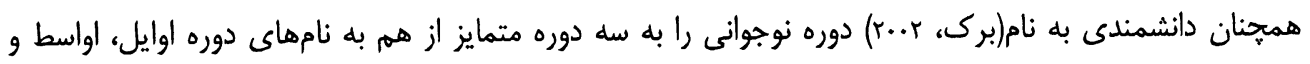

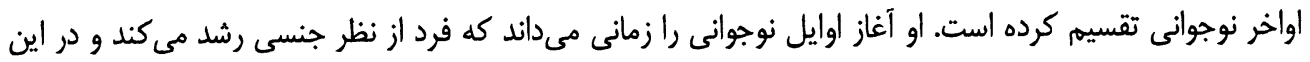

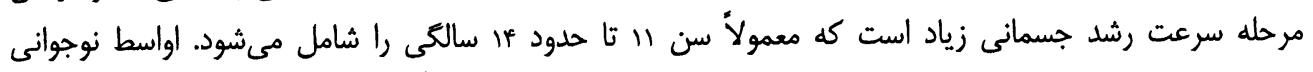

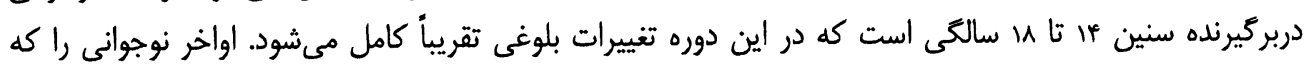


شامل سنين 11 -1 سالكى مى اند، دورهاى است كه فرد نه تنها از نظر ظواهر بلكه از نظر هذيرش نقشهاى

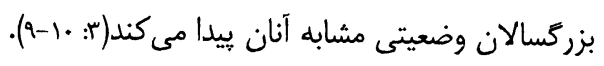

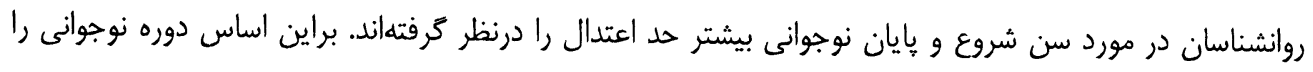
به سه مرحله تقسيم كردهاند: 1. قبل از نوجوانى •ا تا rا سالكى r. آوان نوجوانى rا تا ها سالكى

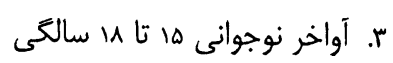

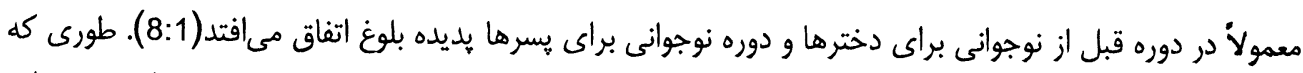

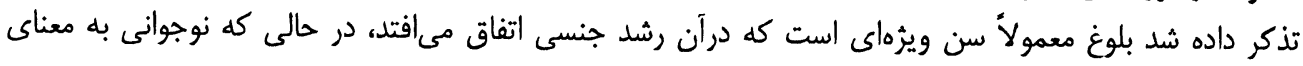
دوره يا سال هاى بين بلوغ و بزركسالى است.

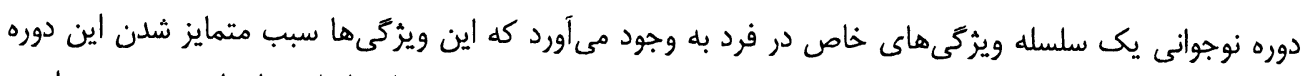

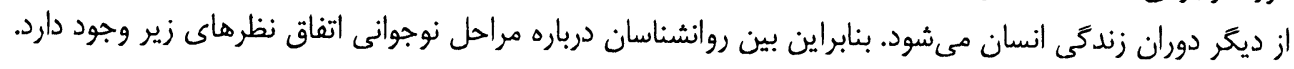

$$
\text { الف- نوجوانى مرحله انتقال از دوران كودكى به بزركّالى است. }
$$

ب- اين مرحله از زندكى با مجموعلى از تغييرات عمده جسمانى، روانى، عاطفى و اجتماعى مشخص مىشود. ج- رشد يك جريان مداوم است كه با مراحل كودكى، نوجوانى و بزر كسالى همبستكى نشان مى دهد لذا بايد انواع خاص تربيث هر دوره مورد توجه قرار گيرد. د- دوره نوجوانى در دختران زودتر از پِسران آغاز مى شود.

ه- رشد و تكامل نوجوان متاثر از عوامل وراثتى، تجارب دوران كودكى، گرايشهاى والدين، نقش كروه

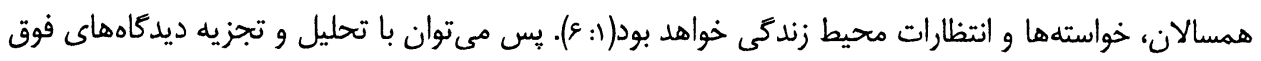

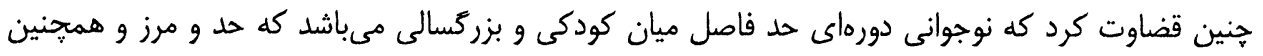

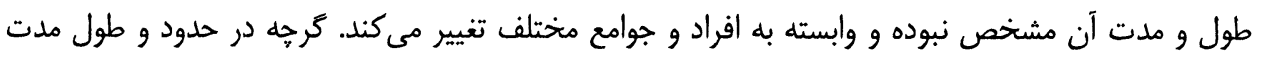

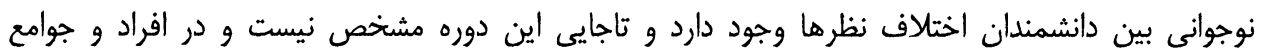

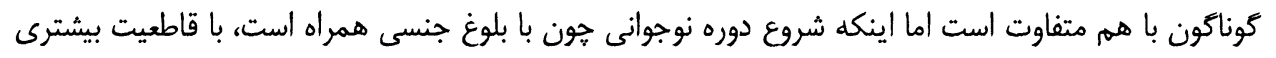

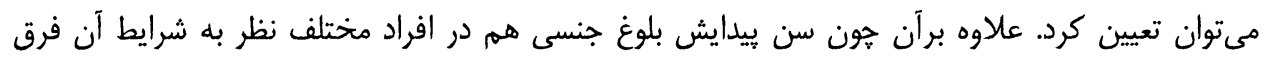

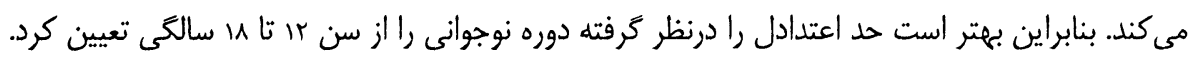




\section{نيازهاى اساسي دوره نوجوانى:}

هر رفتارى كه از انسان سر ميزند به منظور برآورده شدن يكى از نيازها و خواستهاى بدنى و روانى او

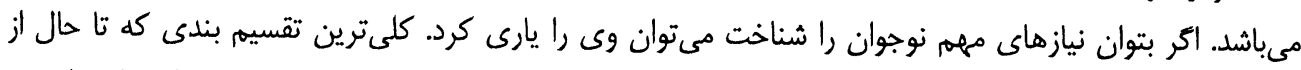

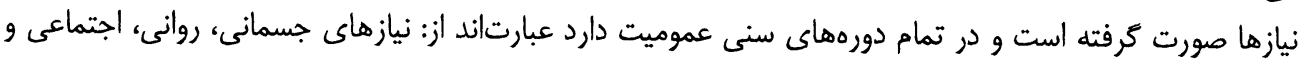

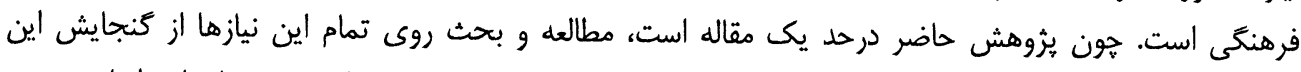

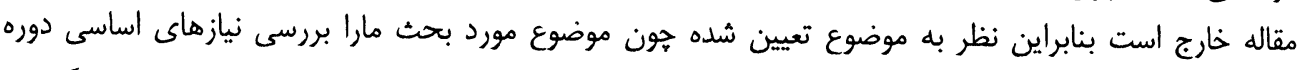

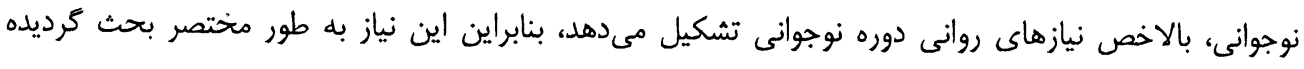

ابتدا اين نيازها را به دو دسته تقسيم كرد:

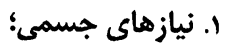

r. نيازهاى روانى؛

1- نياز جسمى( فُيولوزيكى ): نيازهاى بدنى كه بنام نيازهاى اوليه يا فطرى نيز ناميده مىشوند، نيازهاى اساسى هستند كه براى ادامه حيات هر انسان لازمى پينداشته مىشوند كه زندگى بلدون تامين اين نيازها دشوار يا

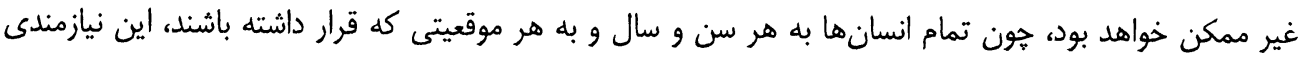

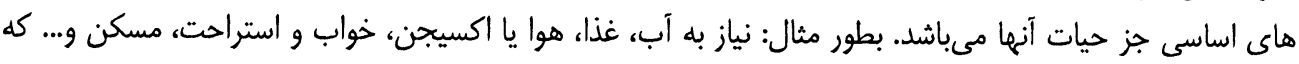

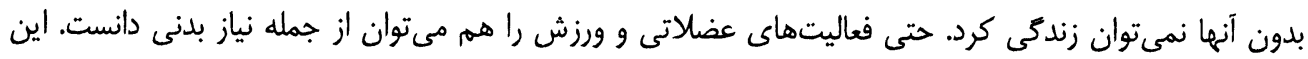

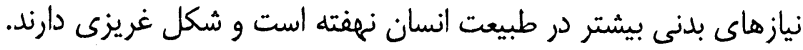

عدم تامين نيازهاى جسمى نه تنها باعث توقف رشد جسمى و گاهى حياتى مى كردد بلكه صدمه روانى نيز دارد.

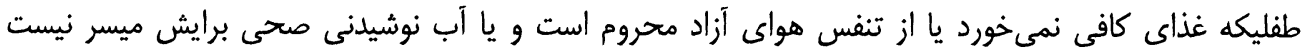

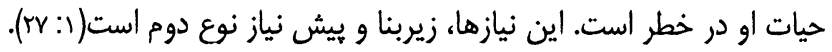

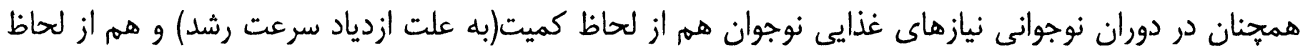

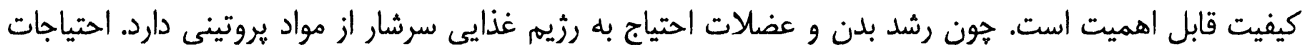

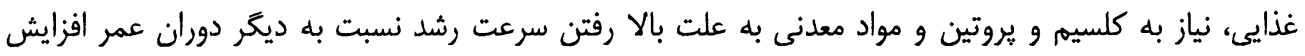

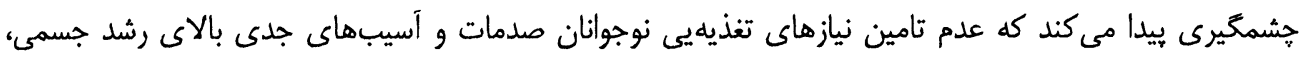
روانى، ذهنى، و اجتماعى او مى تواند به بار آورد.

r - نياز هاى روانى: نوجوانى يك دوره انتقالى از وابستخى كودكى به استقلال و مسوليت يذيرى جوانى و

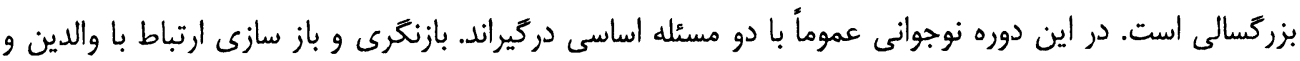


بزركسالان و جامعه بازشناسى و بازسازى خود به عنوان يك فرد مستقل رفتار نوجوانان در اين دوره، كاه كودكانه و

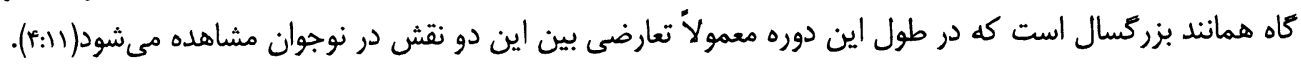
ناكفته نبايد كذاشت كه ازنكاه علم روانشناسى نقش نيازهاى روانى در بالاى فرد كمتر از نيازهاى جسمى نبوده بناً

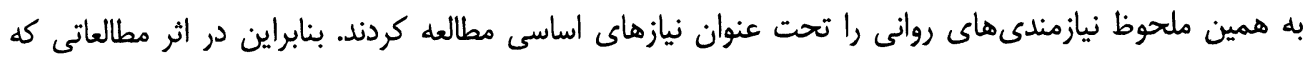

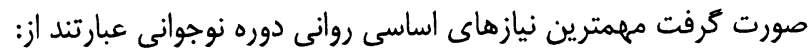

ا-هياز به استقلال و عدم وابستكى: داشتن استقلال و نياز به آن جزء نيازهاى اساسى براى هر انسان است زيرا

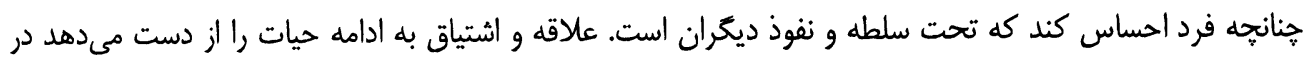

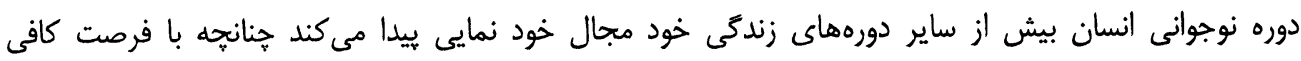

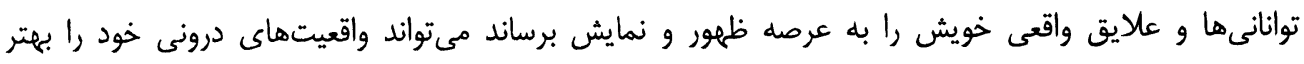

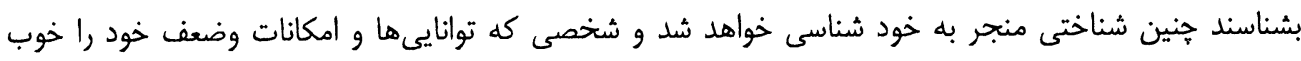

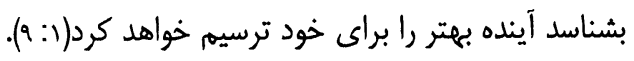

بسيارى از نواجوانان فكر مى كنند كه بدر و مادر بر آنها كنترول و نظارت دارند و ييش خود فكر مى كند كه آنها

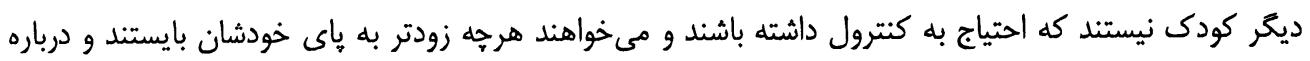

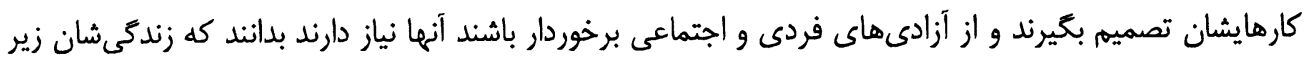

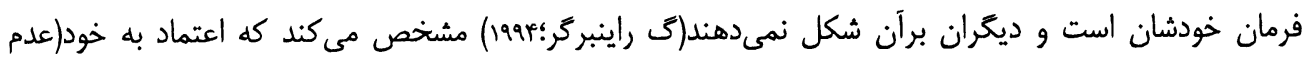

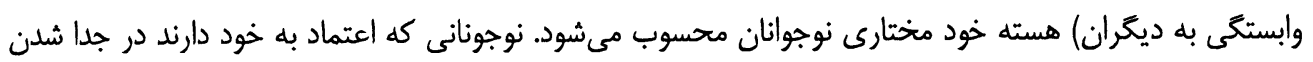

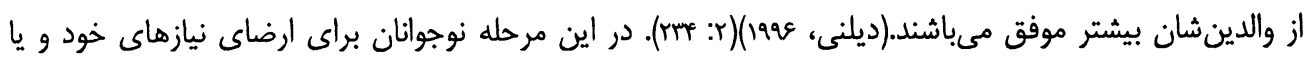

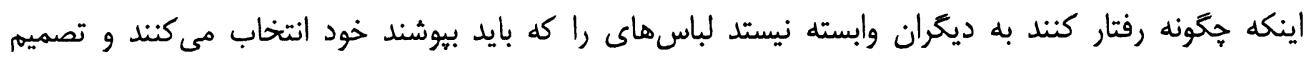

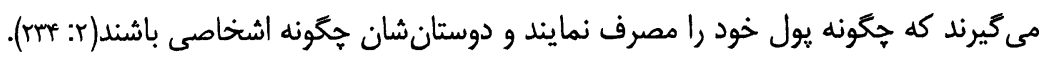
نوجوانان آروزمند هستند استقلال داشته باشند و هر قدر بيشتر به خود متكى باشند عداوتشان نسبت به بزر كترها

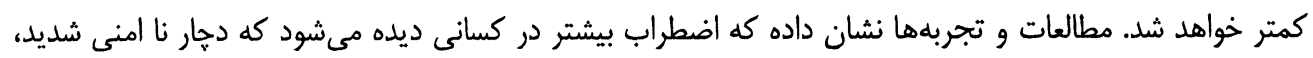

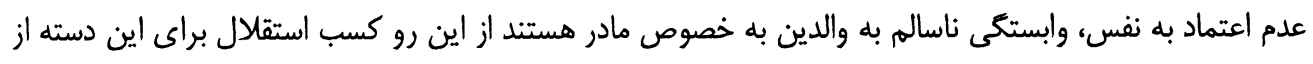

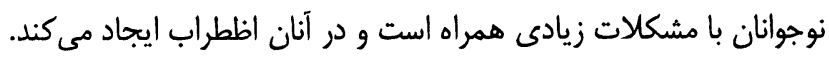

جنانجه تحقيقات نشان داده است كه يكى از مهمترين روشهاى بر قرارى رابطه انسانى با نوجوانان، حفظ و تأمين

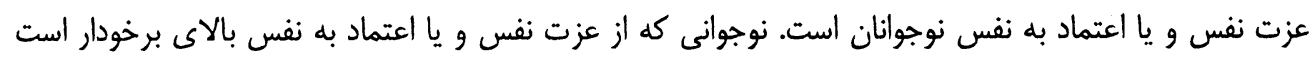

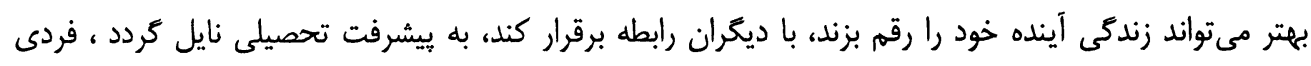

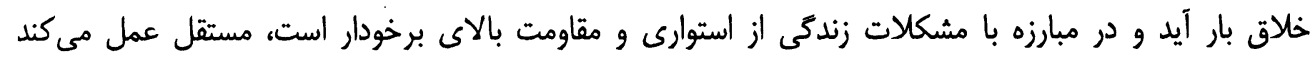

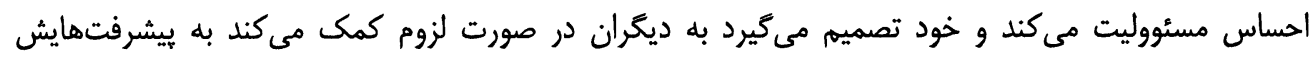

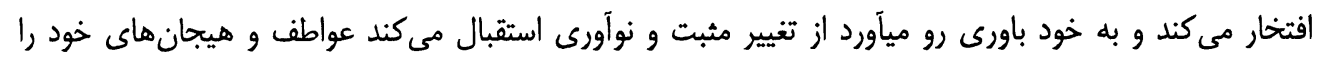




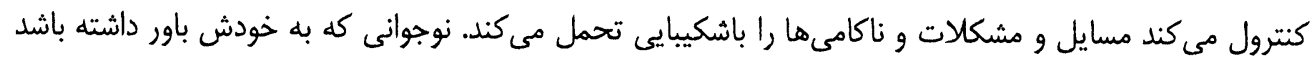

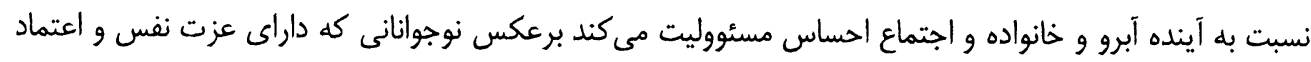

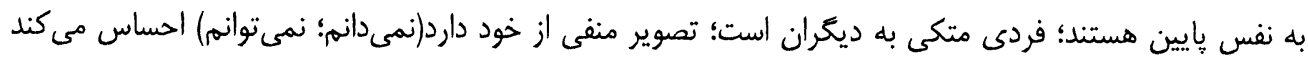

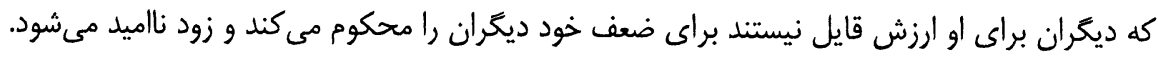

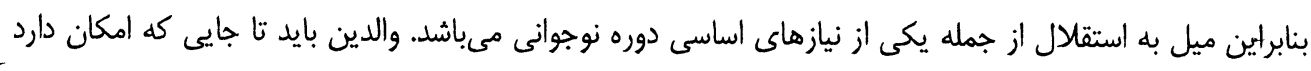

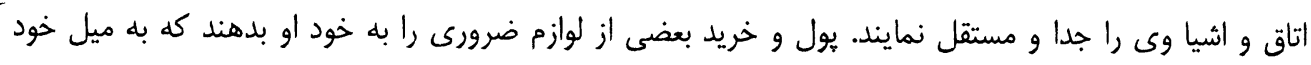

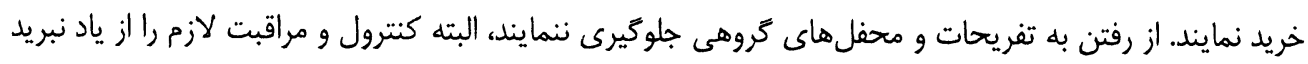

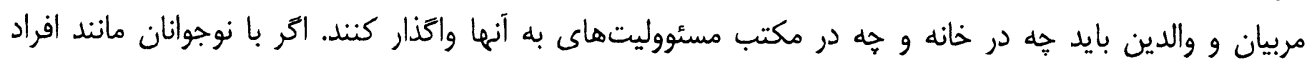

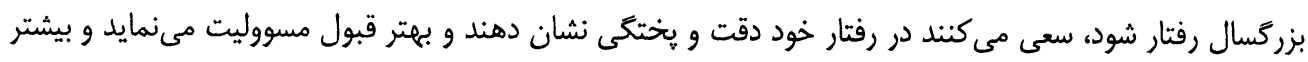

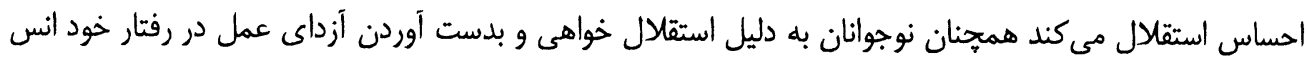

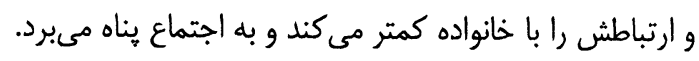

\section{عوامل زيس در بدست آوردن استقلال درنوجوانان موثن مي باشد:}

الف: رشد بدنى در بدست آوردن استقلال مؤثر است. اكر رشد بدنى در بدست آوردن استقلال مؤثر است. اكر

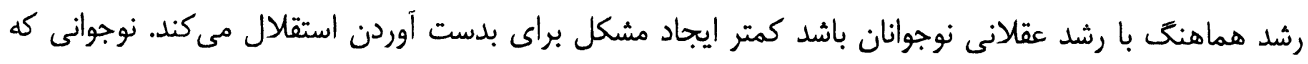

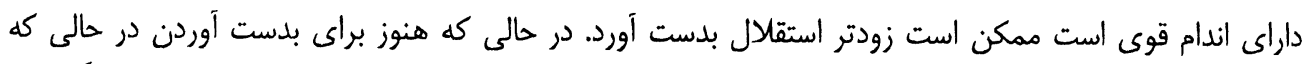

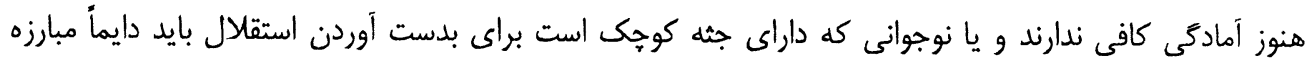

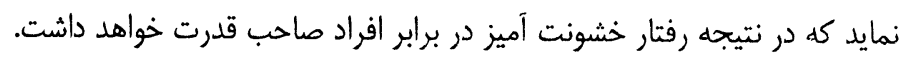

ب: قبول مسئووليت در مقابل اعمال شخص: بايد در اين دوره به نوجوان ياد داد كه مسئووليت اعمال خودش

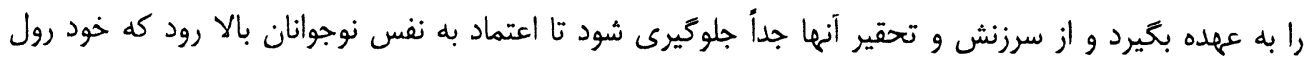
مهمى در بدست آوردن استقال مى وباشد.

ج: كنتسول عواطف و احساسات: نوجوان بايد براى تحمل ناكامى آمادگى كافى داشته باشد و تاخير در رسيدن به هدف را بيذيرد و تمايلات لذت جويانه خود را تحت كنترول درآورد. د: استقلال اقتصادى و شغلى: براى بدست آوردن استقلال نوجوانان بايد داراى شغل باشد و مسئوولين

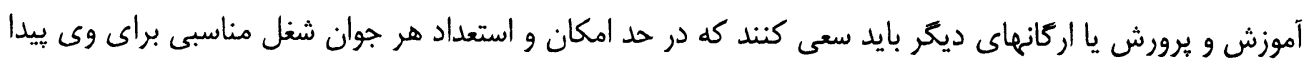
كنند كه در آينده بتواند نيازهاى مادى وى رائر را مرفع سازد. 
r- نياز به محبت و مهـبانى : رابطه نزديك محبت آميز با جند شخصى مؤثر در زندكى غالباً ايجاد رضايت ميكند.

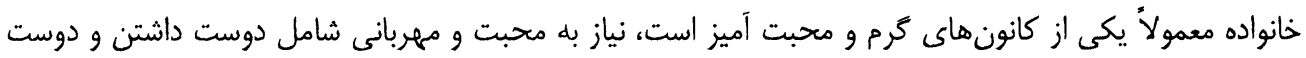

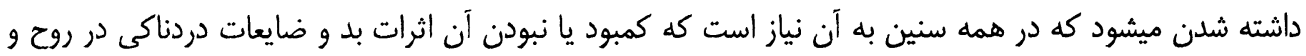

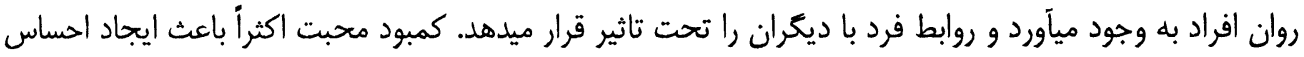

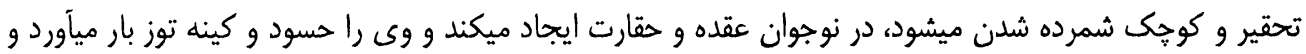
سرانجام باعث احساس تنهاى و انزوا طلبى در نوجوان ميكردد. اكر نوجوان در كانون خانواده از محبت سير سيراب نشاب نشود

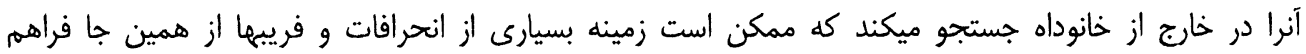

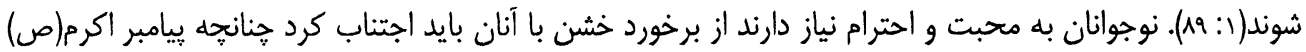

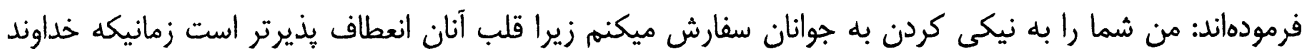

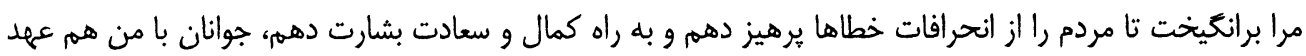

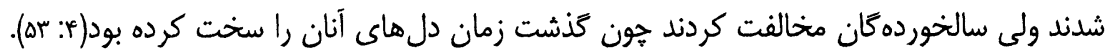

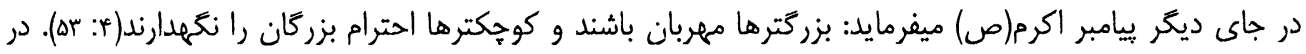

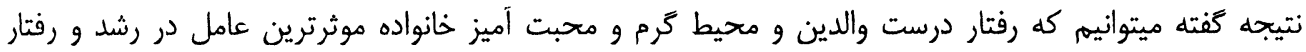

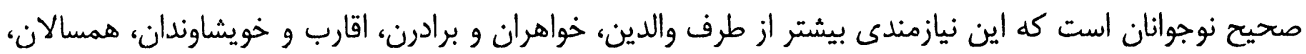

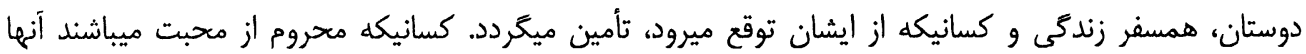

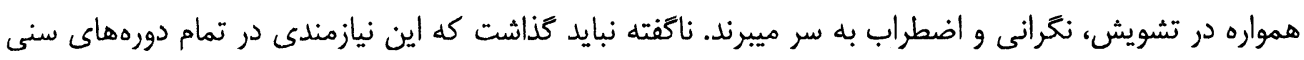
و در بين زن و مرد احساس ميشود.

r- نياز به مصونيت و آرامش : احتياج به مصنونيت از جمله نيازهاى اساسى و روانى است. مصؤنيت داراى جهات مختلف بوده و براى تمام انسانها يك امر ضرورى ينداشته ميشود. از قبيل مصونيت اقتصادى، مصونيت سياسى، اجتماعى، عقيدتى و... احساس امنيت و آرامش بيش از هر جيزى ديخر ادامه زندگى رئى را سهل و و آسان ميسازد.

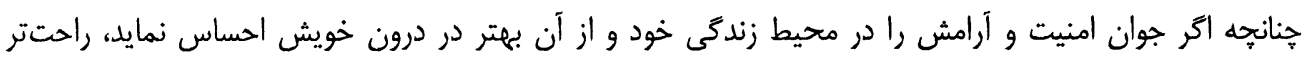

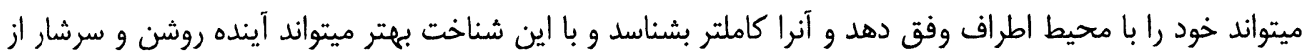
سعادت و نيكبختى براى خود رقهم بزند (1: 19).

هر انسان ميخواهد مطمئن باشد كه كسى به حريم آزادى او تجاوز نكند و مال و جان و آبروى و شخصيت و مواء موقعيت اجتماعىاش هميشه در امان باشد. هر فردى ميخواهد مطمئن باشد كه در موقعيت سختى و ناراحتى تنها

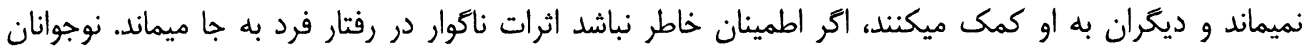

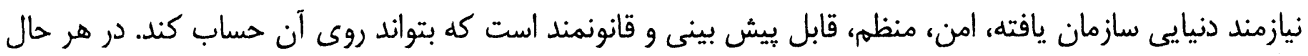

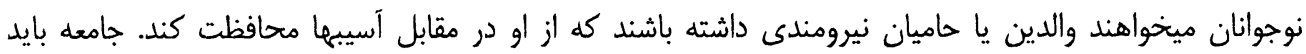

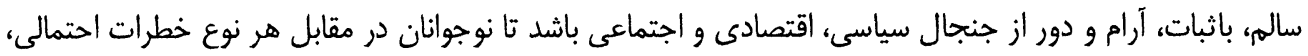


تهاجم، قتل، آشوب، ظلمه، بىعدالتى و نظاير آن خود را در معرض خطر احساس نكند.

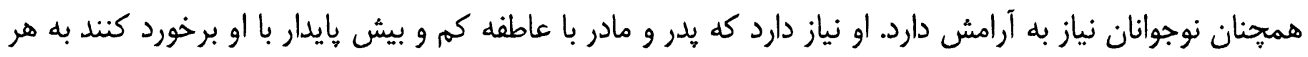

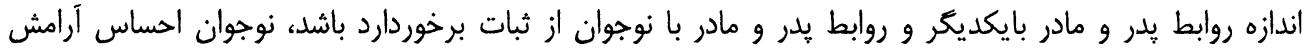

ع- نياز به تعلق گ گوهى و معاثــ با همسالان و مورد قبول همسالان واقع شدن: انسان درهر مرحله از رشد

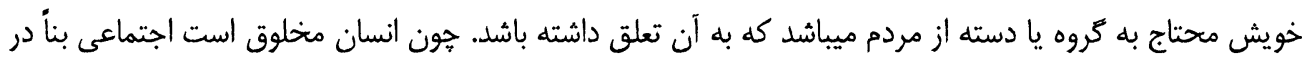

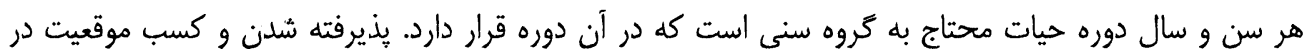

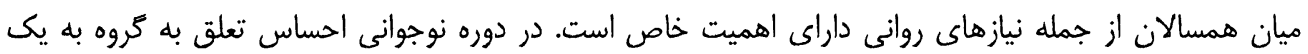

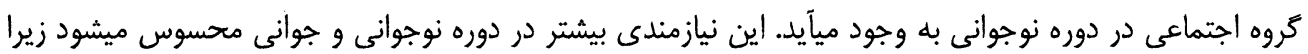

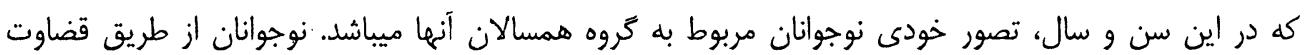

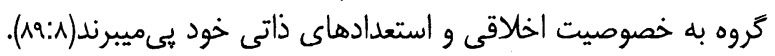

علاوه بر آن تعلق نوجوان به تروه سبب تحكيه شخصيت آنها شده و از طريق اين نوع تعلقات موقعيت و موقف

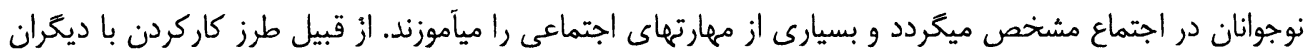

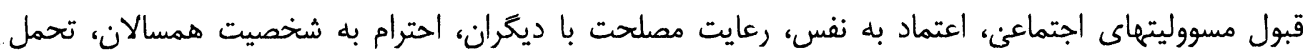

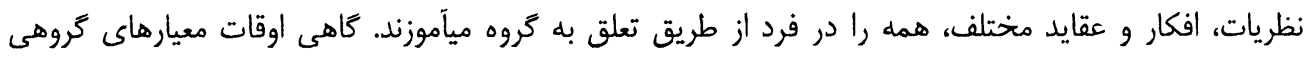

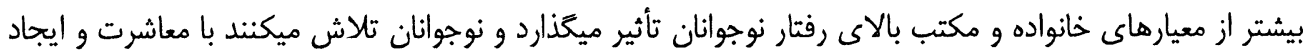

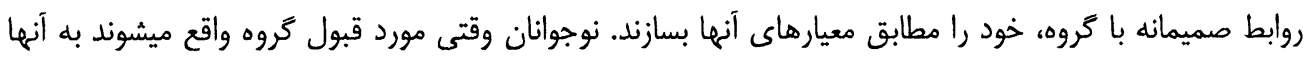

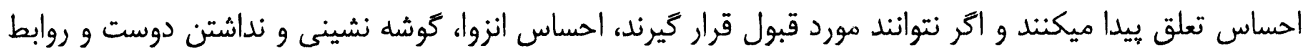

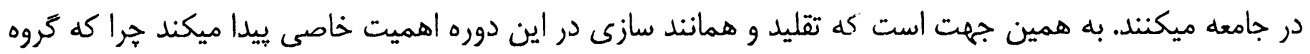

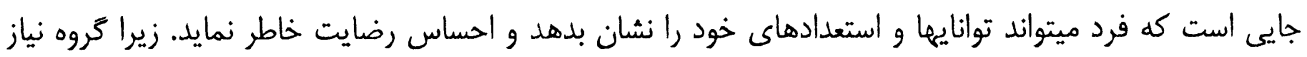

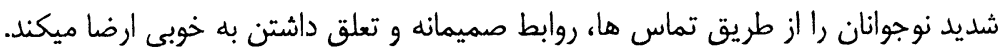
افراد كه از طرف گروه ترد ميشوند و يا به عنوان يك عضو مورد احترام گروه قرار نميخيرند، شخصيت آنها دهار

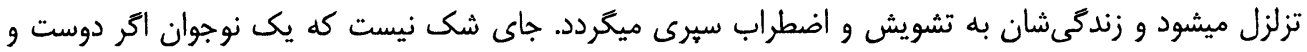

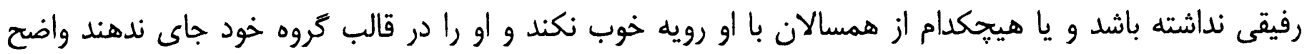

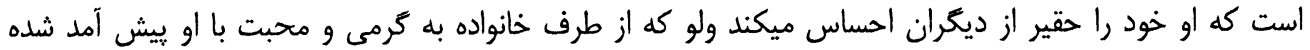

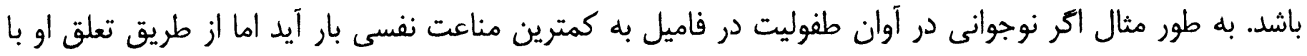

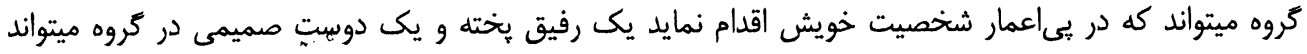

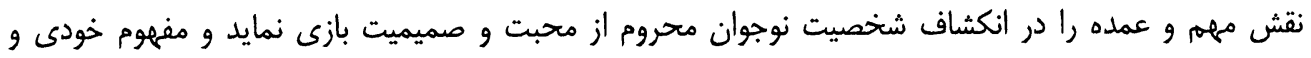
واقعى را در او ايجاد و تقويه نمايد. 
به عقيده من در اين سنين نوجوانان بيشتر علاقهمند تشكيل كروههاى همسالان هم جنس هستند. بيشتر كودكانى

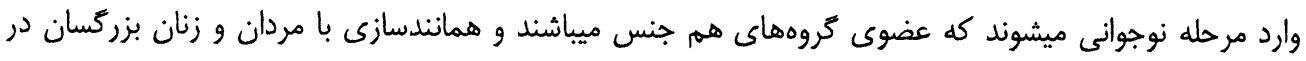
آنها در حال تقويت است.

ه- نياز به بيان افكار و ابنار خودى: يكى ديكر از نيازمندىهاى اساسى روانى نوجوانان، احتياج به بيان افكار و

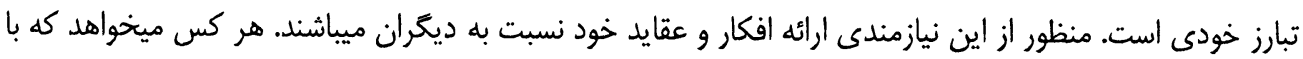

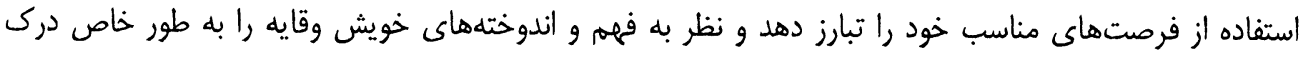

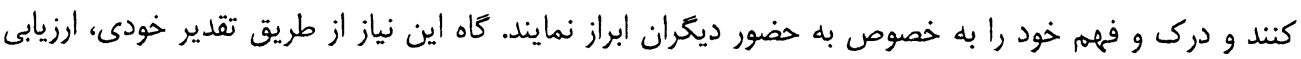

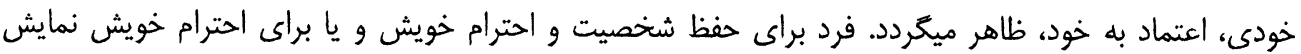

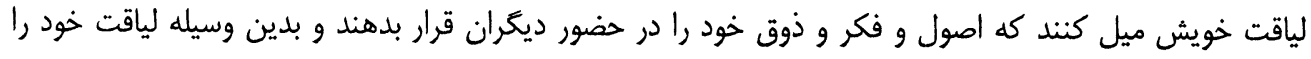

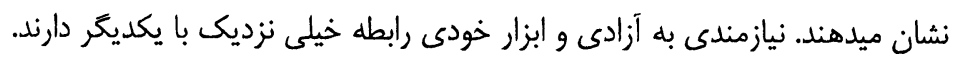

انسان در زندگى به يرابلمهاى مواجه ميشود كه در بعضى اوقات نميتواند به حل آن اقدام نمايد و از برخورد به يرابله

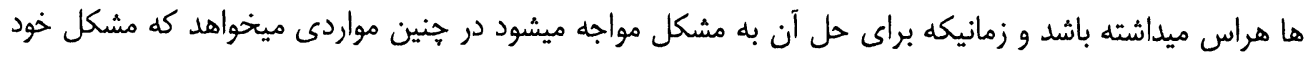

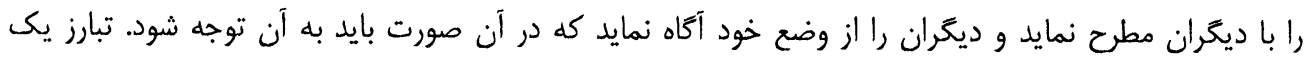

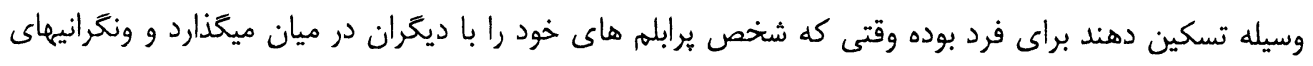

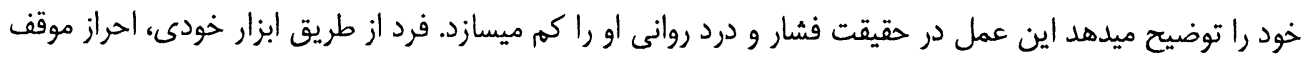

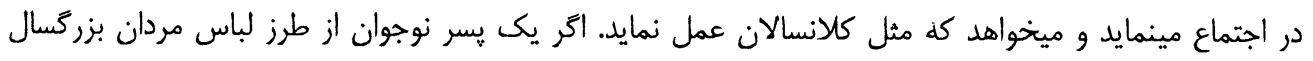

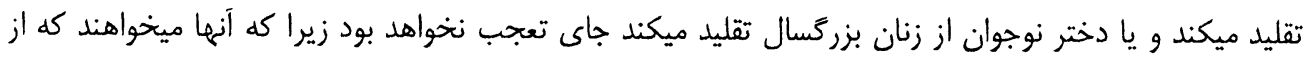

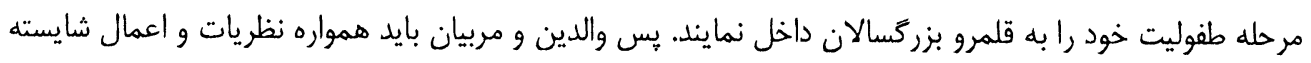
نوجوانان را مورد احترام قرار بدهند.

ج- نياز به قابليت و احتراز: نياز به قابليت و احترام گويايى اين حقيقت است كه كنترول محيط هميشه براى انسان، لذت بخش است و ذاتاً به خودى خود موجب احساس سربلندى و رضايت خاطر ميكردد. نوجوانان به خاطر

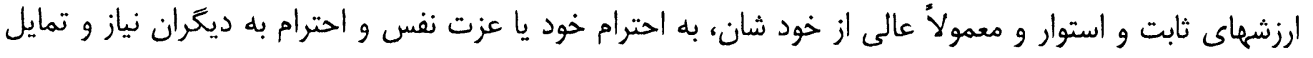

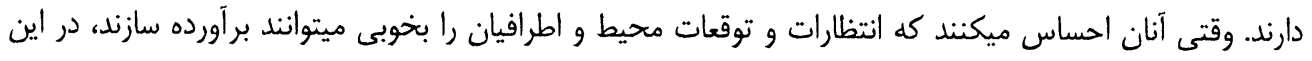

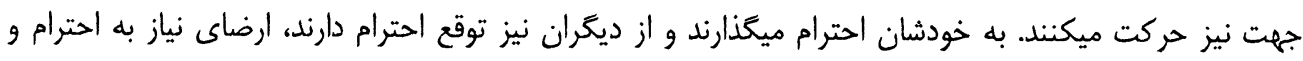

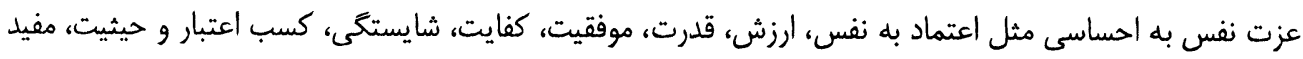

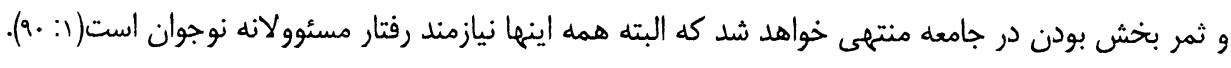
V- نياز به احساس هويت و شناخت حود: از مهمترين نيازهاى ديكرى روانى نوجوان، نياز به احساس هويت و شناخت خود و حفظ تعادل روانى و عاطفى در مقابل عوامل و فشارهاى درونى و بيرونى است. يافتن هويت واحد و 
مشخص در نوجوان اين امكان را ميدهد تا بتواند در سايه آن به شناخت خود و محيط اطرافيان خود دست يابد.

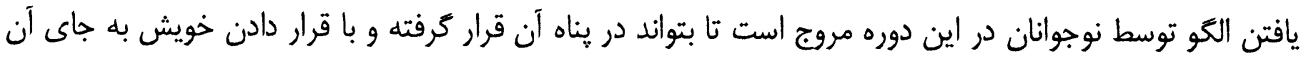

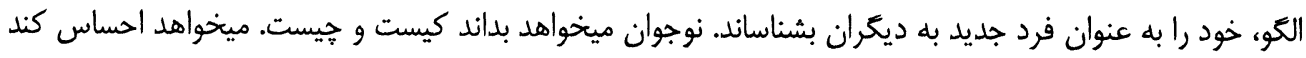

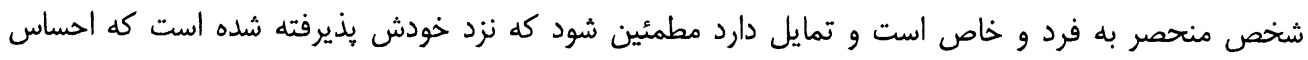

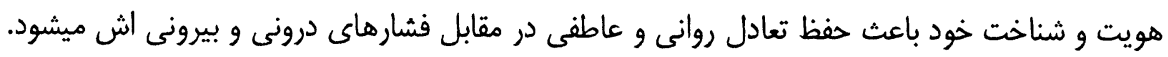
^- نياز به احساس رشد، كال و خود شكَوفاى: نوجوانان علاقه و تمايل دارند كه هرأنجه را در درون خود

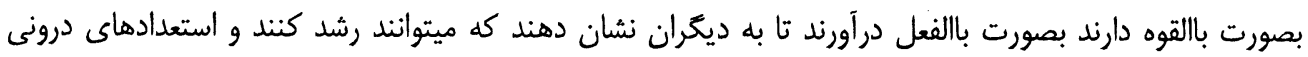

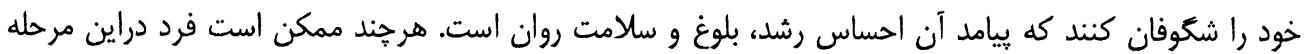

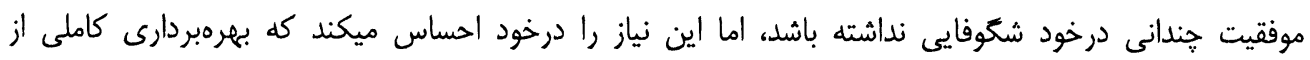

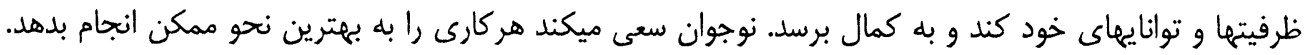

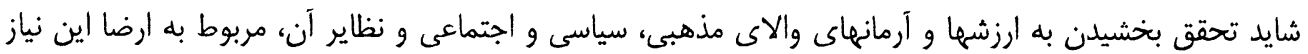

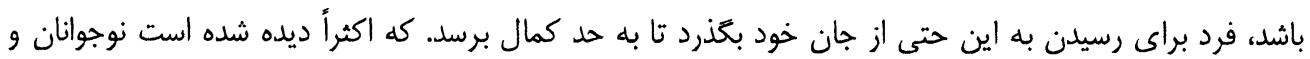

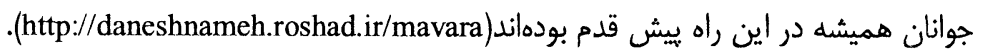
و- نيازبه تشخيص و قدردانى: نوجوان نياز دارد كه اطرافيان ارزش زحمات و كارهاى مفيدش رادرك كنند و از

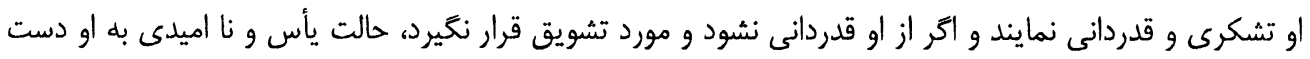

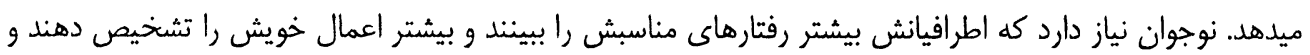

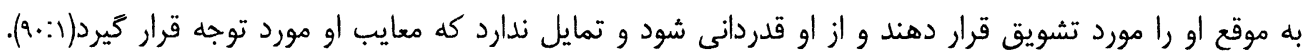

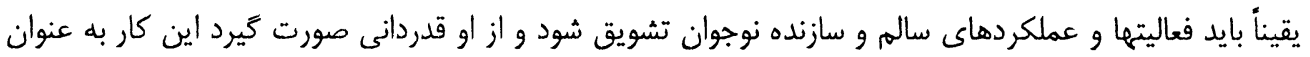

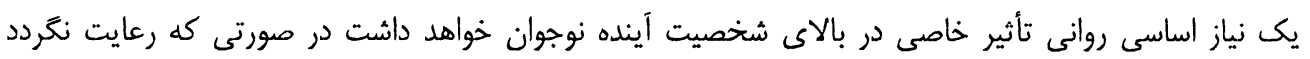

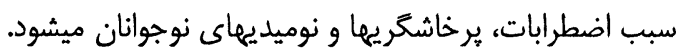
•1- نياز به داشتن هدف، نظم و تهتيب در زندگى : به طور كلى زندگى بدون هدف بىمعنا خواهد بود و هركسى

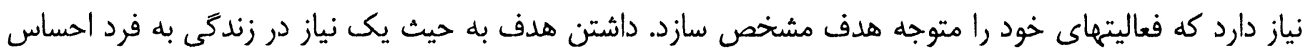

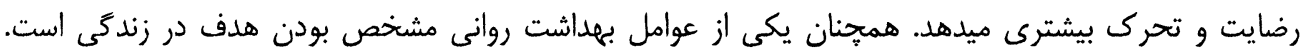

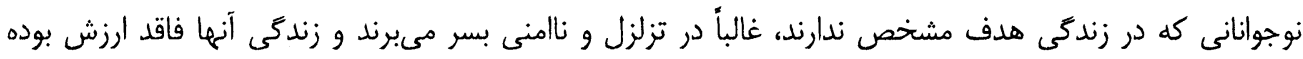

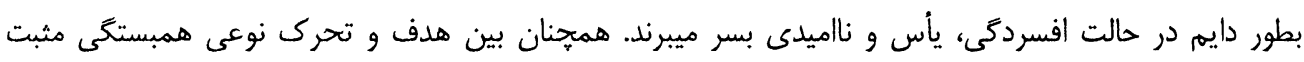

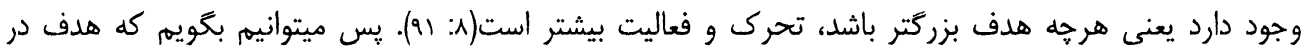

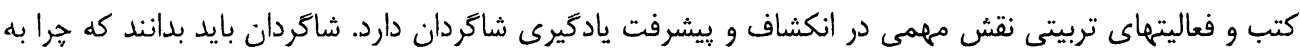

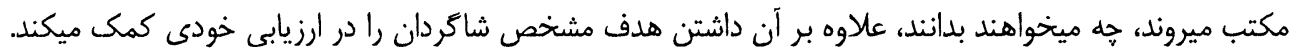




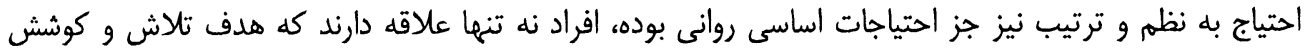

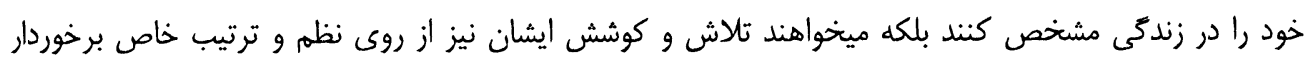

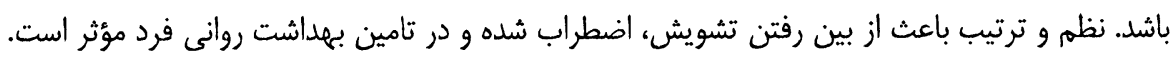

"1 - نياز به درك موقعيت و جايكاه: نوجوانان بسيار نيازمند قبول شرايط و موقعيت خود توسط اطرافيان خصوصاً

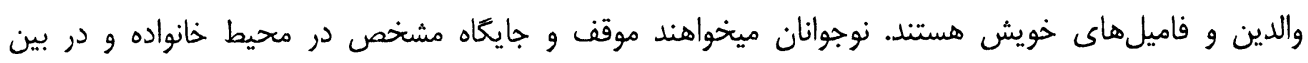

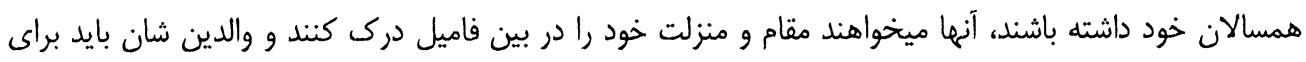

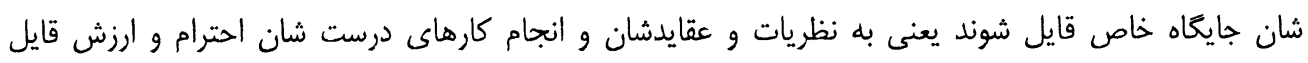

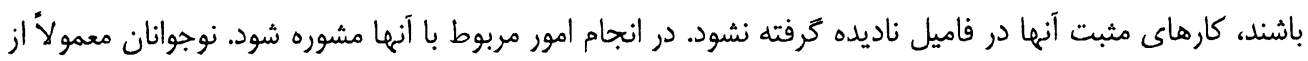

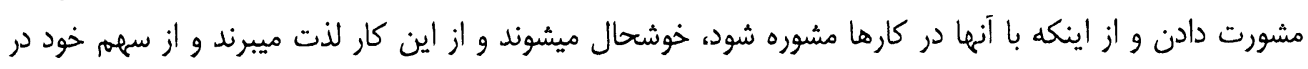

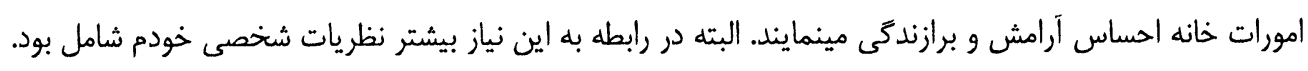

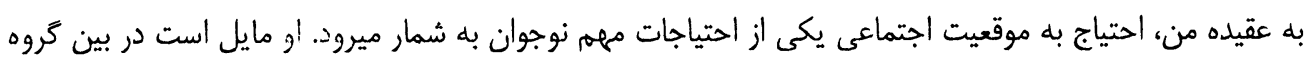

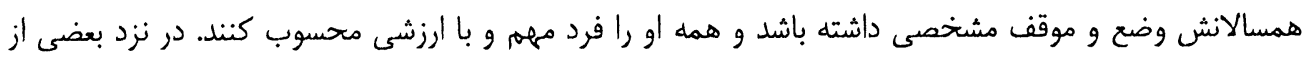

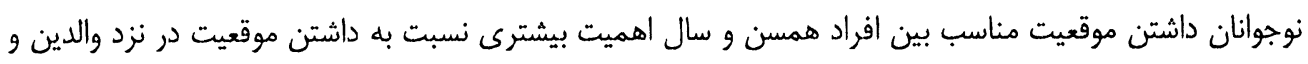

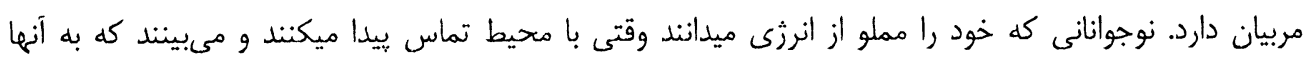

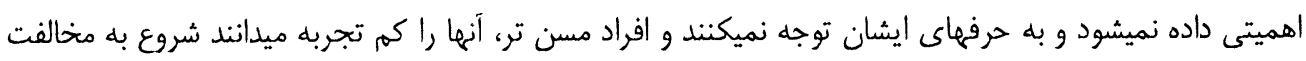

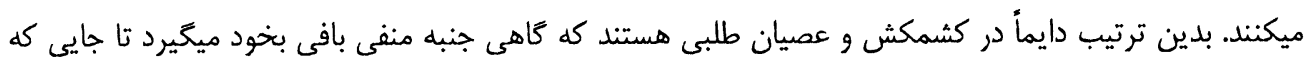

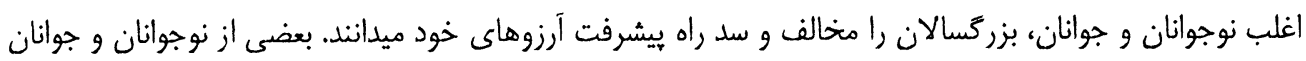

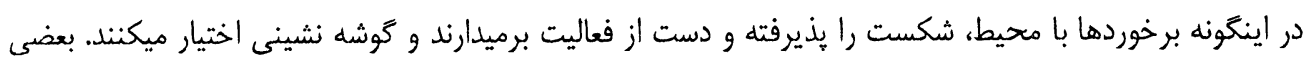

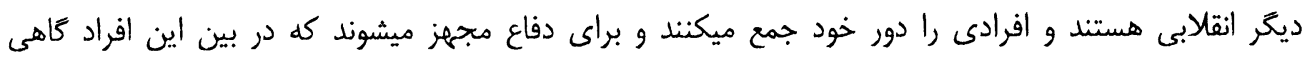

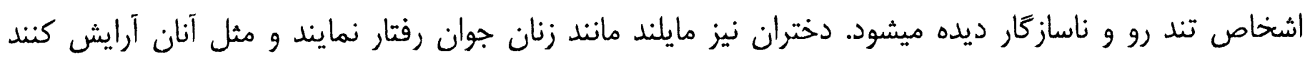

ولباس بيوشند.

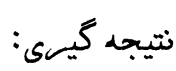

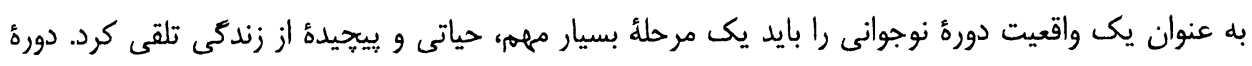

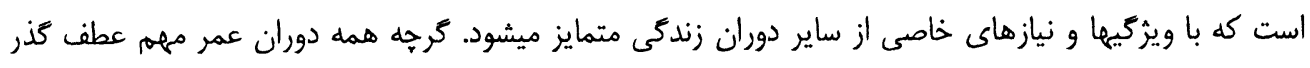

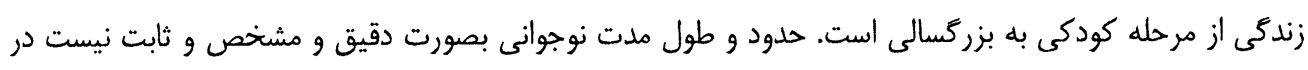

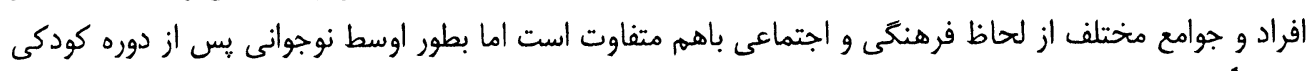

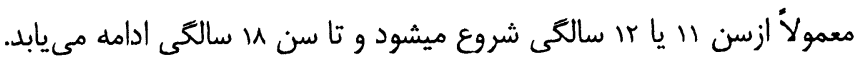

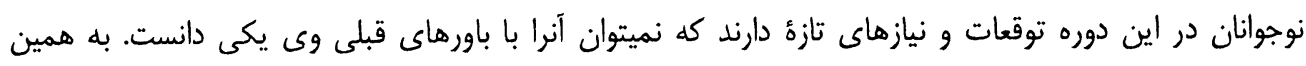

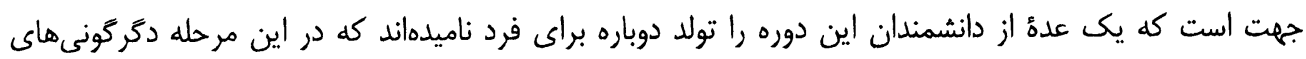


زيادى در ابعاد جسمى، روانى و اجتماعى وى به وجود مياًيد. درطول تاريخ نكرشهاى مختلفى نسبت به دوره

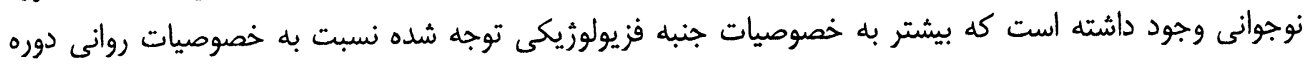

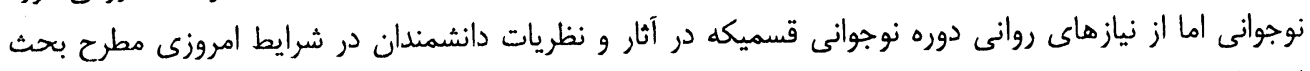

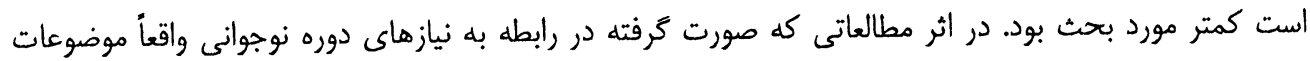

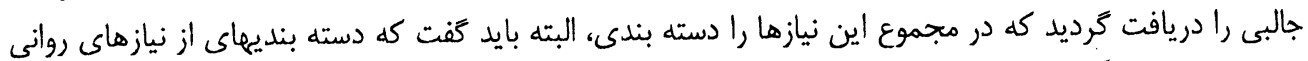

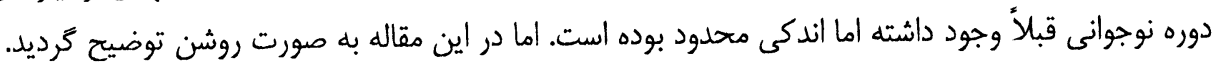
در اثر مطالعات كه صورت گرفت نياز به معناى مختلفى استفاده شده است كه در لغت به معناى احتياج و ضرورت

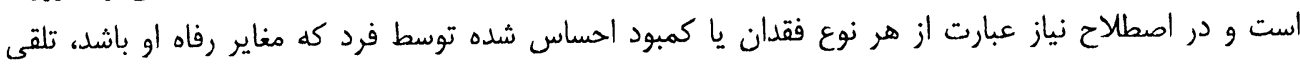

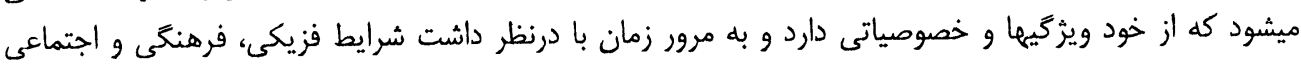

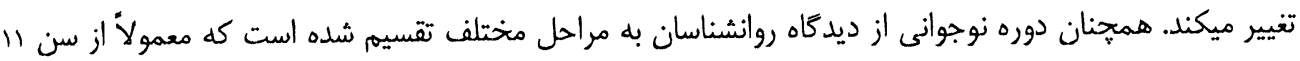

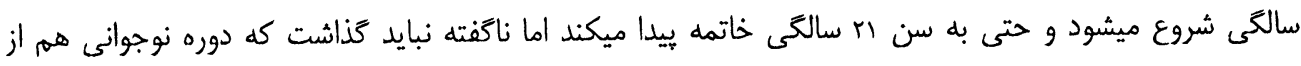

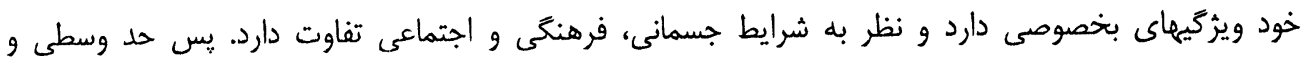

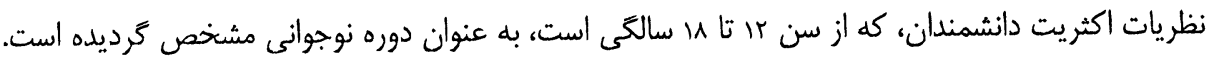
در اثر مطالعاتى كه صورت گرفت، نيازهاى روانى دوره نوجوانى عبارت از: نياز به استقلال و عدم وابستخى، نياز به به به بهاز

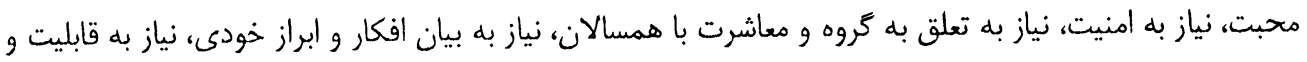

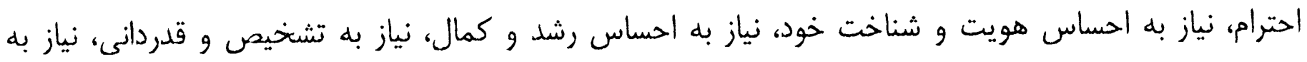

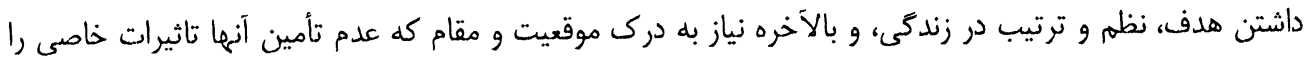

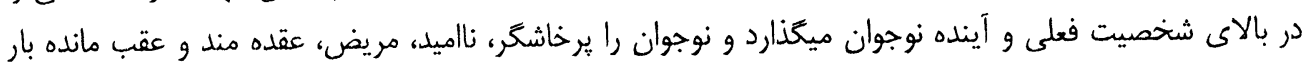

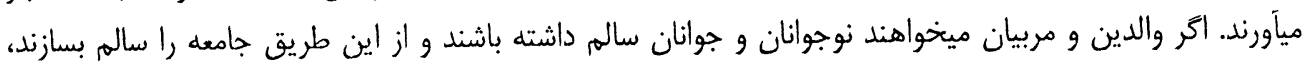

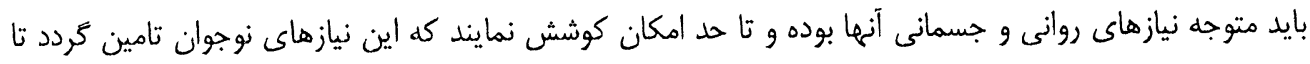

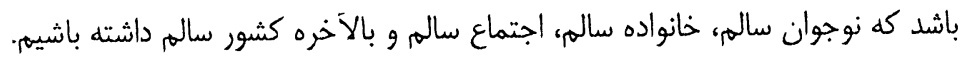

\section{ييشنهادات:}

ا. والدين مكلف هستند به همان اندازه كه به نيازهاى جسمانى فرزندان و نوجوانان اهميت ميدهند، به نيازهاى روانى و عاطفى آنما نيز توجه نمايند.

r. والدين و مربيان متوجه باشند كه نوجوانان به طور معمول نيازشان را به طور مستقيم ابراز نميكند و بايد از رفتار أنزها به نيازهايشان يكى ببرند. 


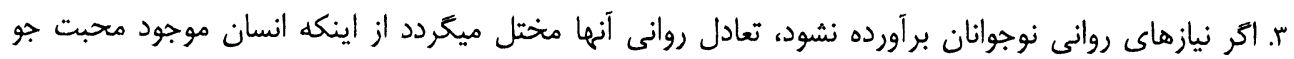

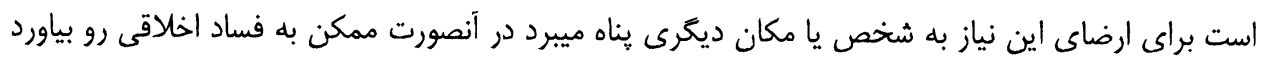
بناً بايد در جهت رفع نيازهاى روانى او كوشا بود.

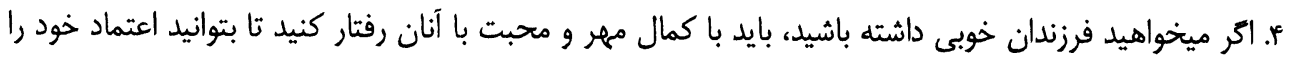
در نزد آنان جلب كرده و در حل مشكلات روانى، ايشان را هدايت و راهنمايى نمايند.

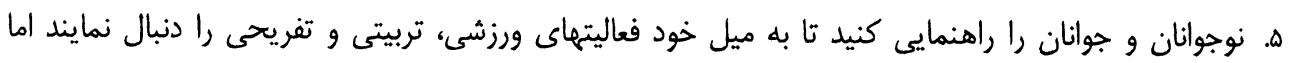

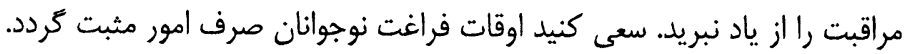
و تلاش كنيد نوجوانان و جوانان با همسالان نيك همنشينى و معاشرت داشته باشند. r. تلاش كنيد محيط خانواده را فضاى مناسب، دوستانه و صميمى بسازيد و گرنه كَهر قيمت بهاى جوان از

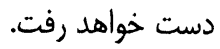
1. به نظريات و شخصيت نوجوان اهميت بدهيد. 9. به خود شناسى و خود باورى فرزندانتان دقت نموده راهنمايى درست نماييد. .1. إز مقايسه و تشبيه نمودن فرزندانتان با ديكر افراد خود دارى كنيد. 11. از خشونتهاى خانوادگى در حضور نوجوانتان جداً خود دارى كنيد. rا. با نوجوانانتان مشوره كنيد و به آنها در حد سن و سال و توانشان مسُوروليت بدهيد. זا. رفتارهاى مثبت و كارهاى خوب نوجوانان تان را تشويق كنيد. 1\% ا. در تربيت نوجوان والدين بايد هماهنكى رادرنظر بخيرند. ها. فضاى احترام و ارزش متقابل بين بدر و مادر و فاميل بايد وجود داشته باشد زيرا اين كار بالاى روحيه نوجوانان و جوانان فوقالعاده أثاثير ميكذارد. 
1- اكبرى، ابوالقاسم. مشكلات نوجوانان وجوانان. تهران: انتشارات رشد وتوسعه،

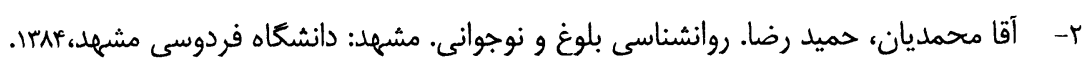

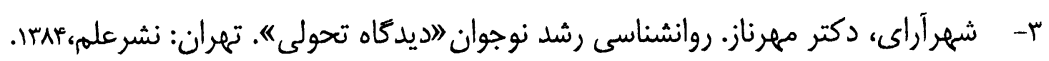

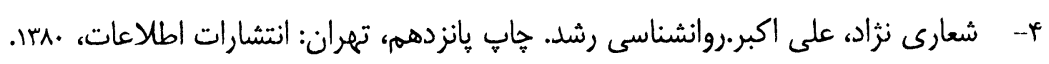

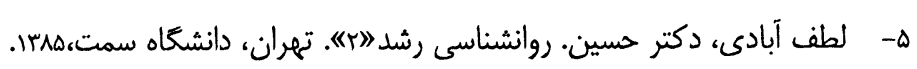

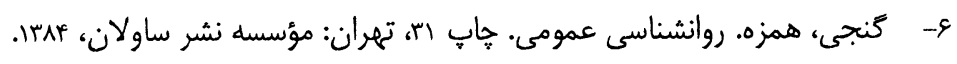

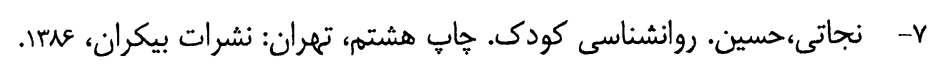

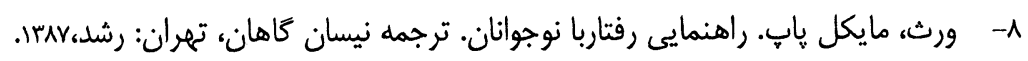




\section{مصالح مر سله بحيث يكى ازمنابع قانونكذارى \\ درنظام حقوقى ازديدكاه دين اسلام}

يوهندوى دادمحمد نذير.

استاد بوهنحئ شر عيات

مقدم: مä

مصالح مرسله مانند استحسان، سدالذرايع، عرف، استصحاب الحال، شرايع قبلى وعمل صحابى از جمله منابع تبعى تشريع درسيستم حقوقى اسلام محسوب ميشود وعلت اينكه از ديدكاه فقهاى اهل رأى، مصالح مرسله بهابه

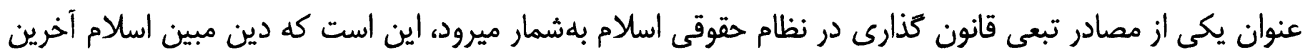

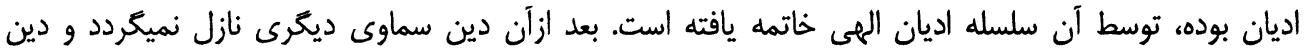
اسلام دين جاويدان براى جامعه بشريت خواهد بود. بدين معنى كه دين اسلام تا آخرعمر دنيا باقى بودها و و درتمام

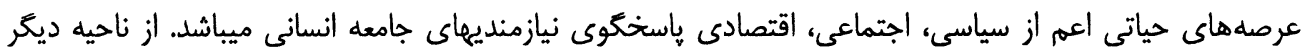

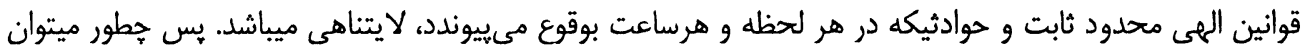

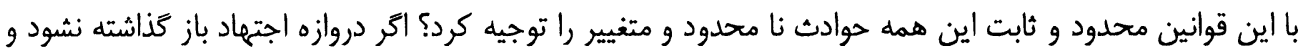

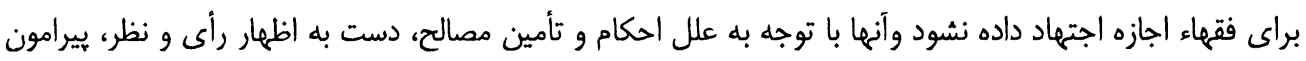

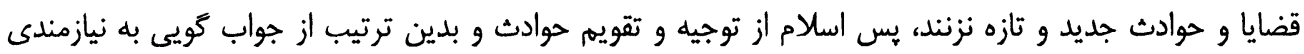

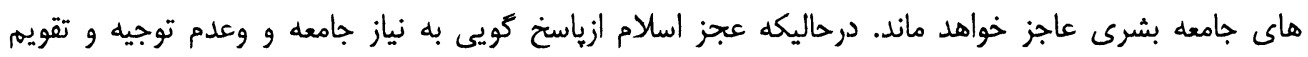

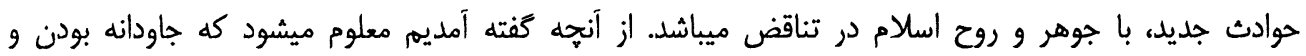

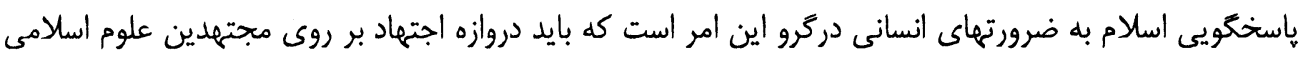

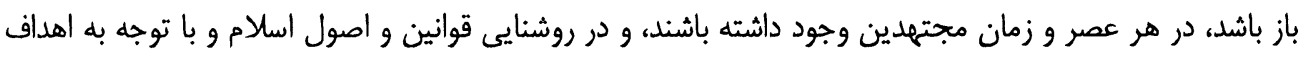

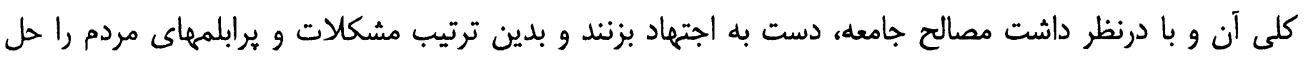

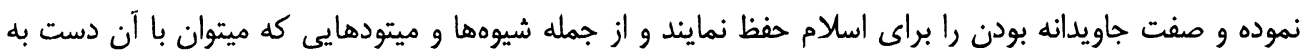

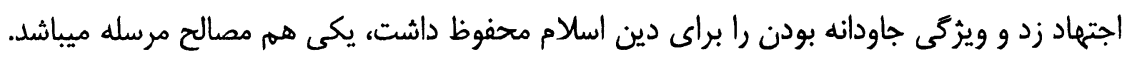

\section{ييشينه تاريخى موضوع:}

زمانيكه به تاريخ فقه اسلامى و وقايع فقهى نظر نماييه، اين امر را درى خواهيم كرد كه اولين وازٔهيى كه

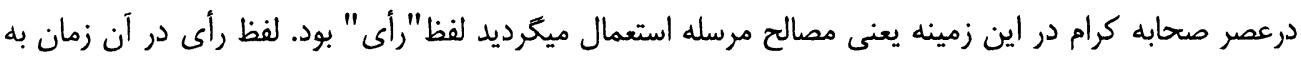

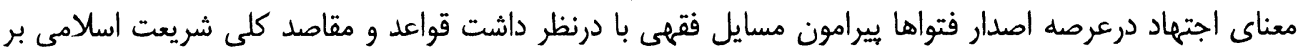

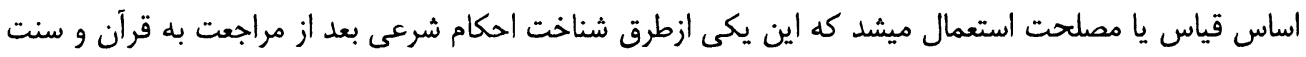

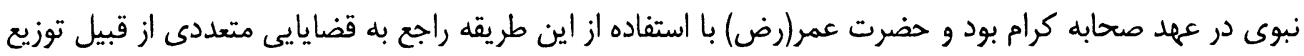


سرزمينهاى سواد عراق بر فاتحين آن، قضاوت در مورد عدت زنى كه شوهرش مفقود كرديده بود و غيره احكام و

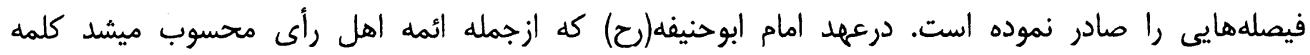

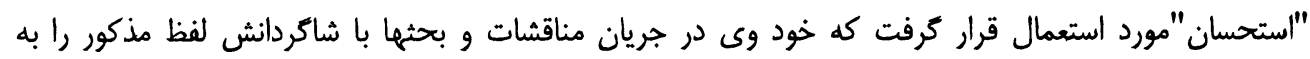

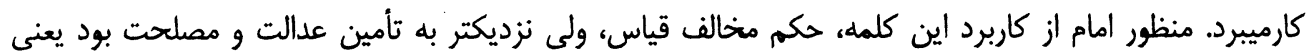
حكمى كه نسبت به آنجه كه مقتضاى قياس است به روح و جوهر شريعت اسلامى نزديكتر است، بود. بعداً امام

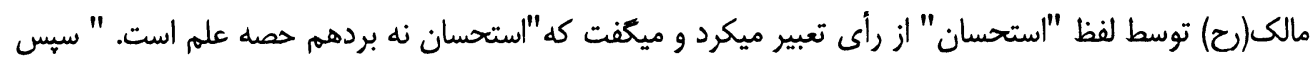

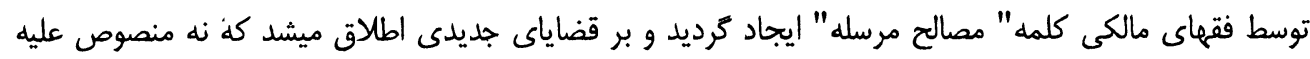

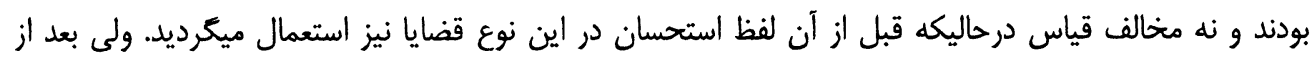

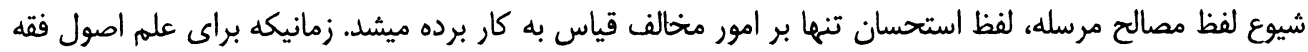

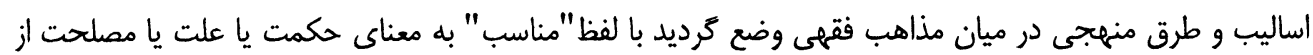

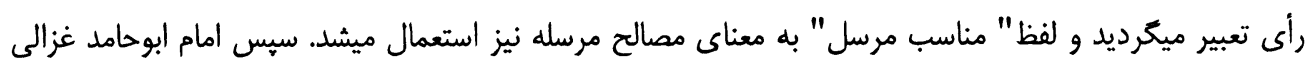

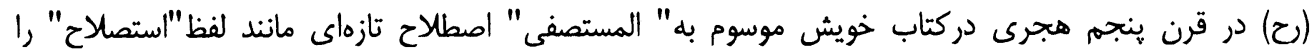

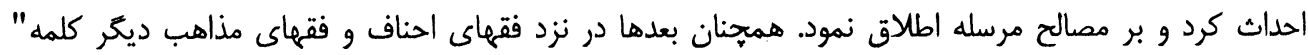
سياست شرعى" به مفهوم.استحسان و استصلاح در عرصههاى حقوقى و مجازات تعزيرى به كاربرده ميشد(و. (ث).

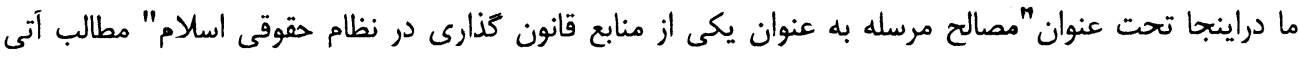

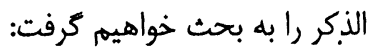

\section{1-مفهوم مصالح وانواع آن:}

الف- مفهوم مصالح: مصالح جمع مصلحت بوده و در لغت به معناى منفعت و همجنان فعليكه در آن نفع و فايده باشد، استعمال گرديده است.

ب - انواع مصالح: مصالح مردم به اعتبار اينكه در نزد خداوند \ج" معتبر است، يا معتبر نيست، يا مرسل است به

$$
\text { سه نوع تقسيه گرديده است: }
$$

1- مصالح معتبره: آن عبارت از يك رشته مفاهيمى است كه در نتيجه ارتباط حكم به آنها جلب منفعت و دفع

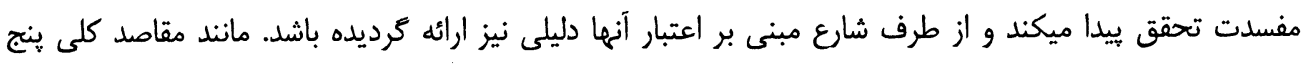

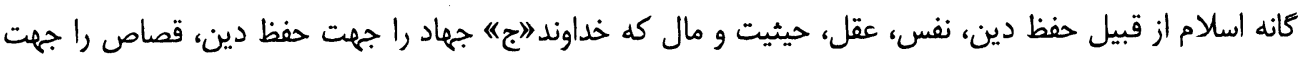

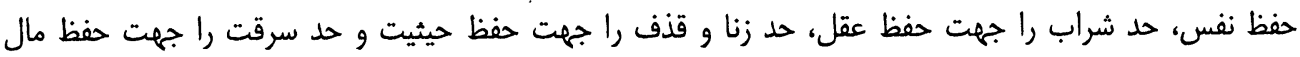
مقرر داشته است.

2- مصالح ملغاه: آن عبارت از يك سلسه مفاهيمى است كه در اثر ارتباط حكم به آنها جلب منفعت و دفع مضرت

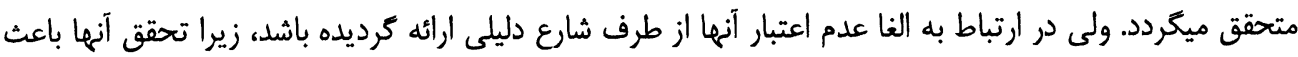




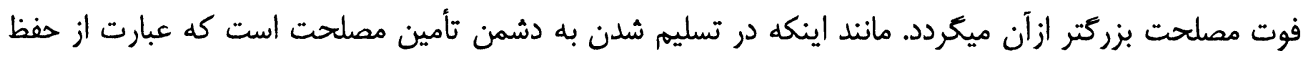

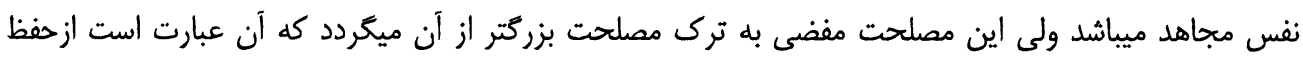

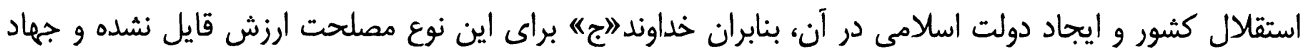
در مقابل دشمن را فرض كردانيده است.

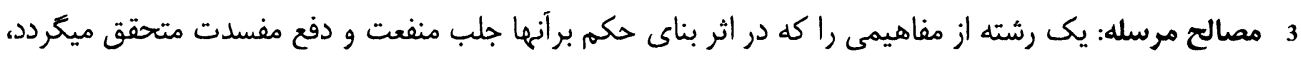

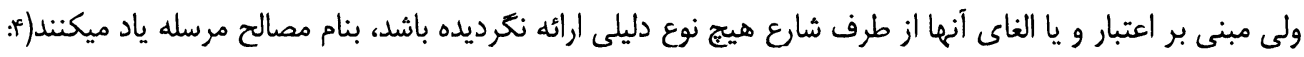

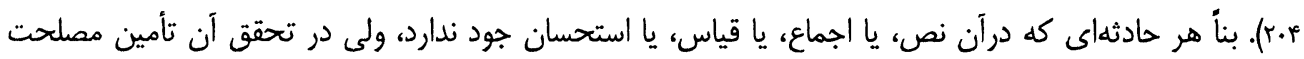

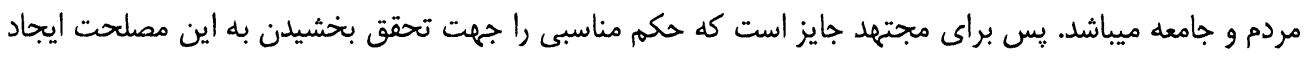

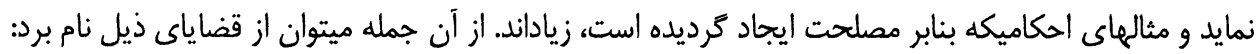

$$
\begin{aligned}
& \text { الف- جمع نمودن قرآن در يك مصحف توسط حضرت ابوبكر(رض). } \\
& \text { ب- ايجاد ديوانها توسط حضرت عمر(رض). } \\
& \text { ج- تأسيس بندى خانهها در زمان حضرت عمر(رض). } \\
& \text { د- قصاص يك گروه در مقابل قتل يك نفر. }
\end{aligned}
$$

ه- يرداخت ضمانت از طرف صنعتكران زمانيكه اموال مردم را تلف مينمودند.

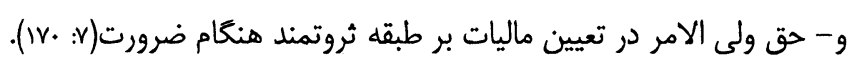

2- معيار بودن مصالح مسله:

بايد متوجه شد كه مصالح مرسله داراى دو اعتبار يكى اعتبار ذاتى و ديخرى عدم منافات با مقاصد كلى

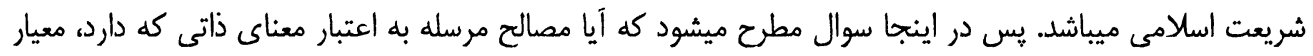

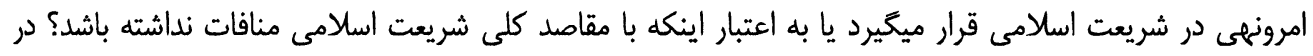

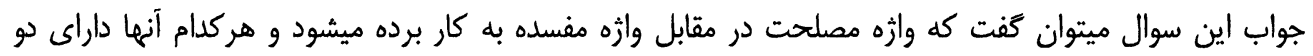

$$
\text { اعتبار ميباشد. }
$$

الف- - معناى ذاتى مصلحت ومفسده: به اين اعتبار مصلحت به مفهوم منفعت و مفسده به معناى ضرر تفسير ميكردد،

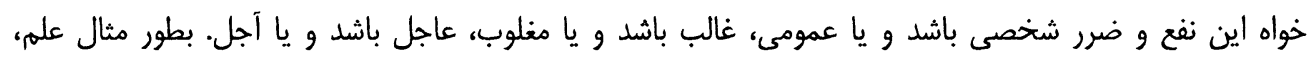

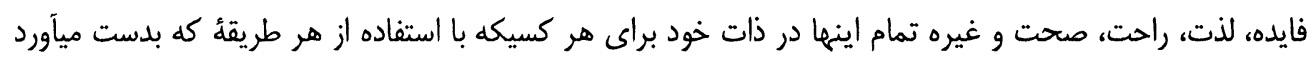

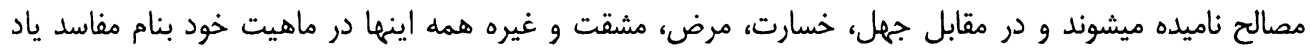

ميكردند. 
اما مصلحت و مفسده به اين لحاظ نميتوانند معيار امر و نهى قرار كرفته و اساس احكام شرعى محسوب گردند زيرا

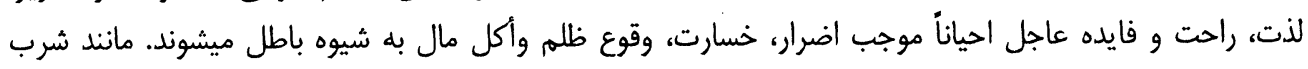

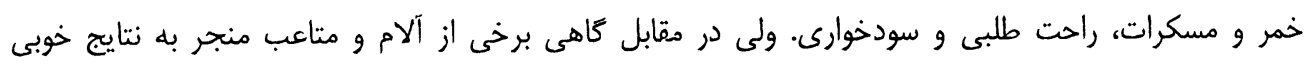

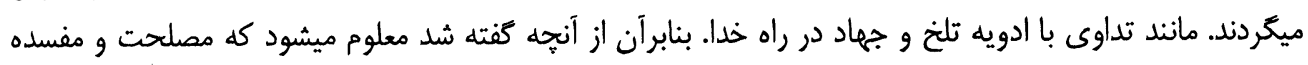

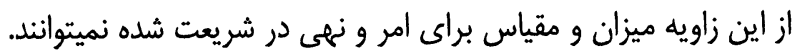

ب- اعتبارشـى مصلحت ومفسده: اعتبار شرعى مصلحت و مفسده به اين معنى است كه مصلحت و مفسده در

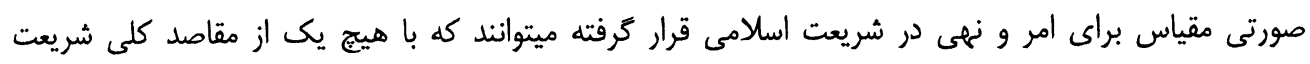

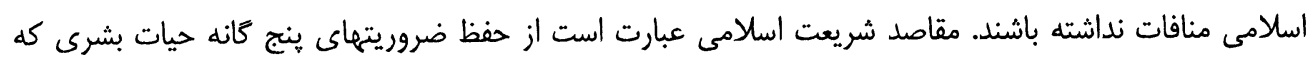

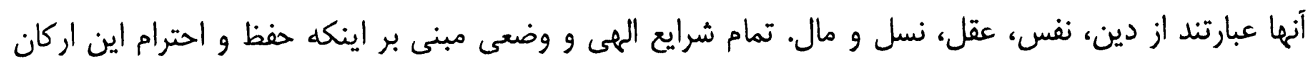
ينجكانه ضرورى و لازمى است اتفاق نظر دارند.

با توجه به نصوص قرآن و سنت نبوى "اص" فقهاى اسلام امورى را كه مصالح انسانها به آنها متعلق است، به سه

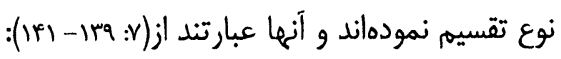

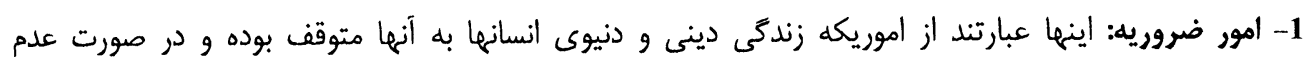

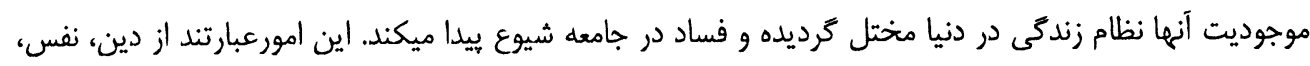

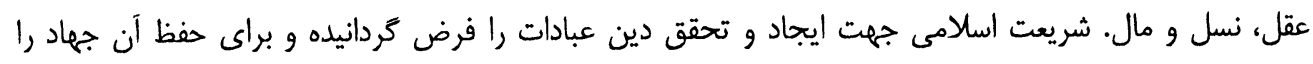
ضرورى و عقوبت مرتد را مقرركرده است.

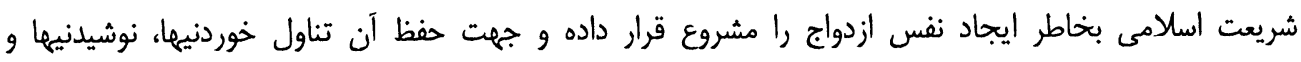

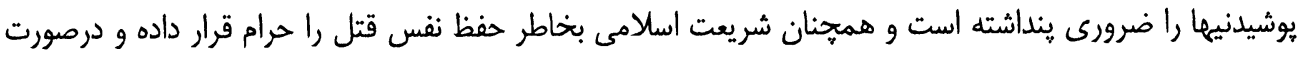
ارتكاب آن قصاص، ديت و كفاره را مقرر داشته است.

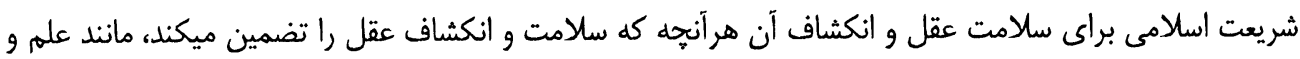

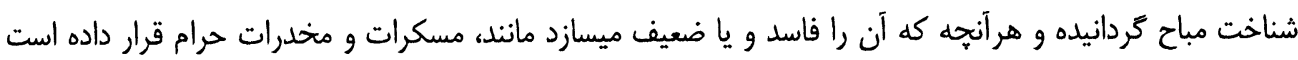

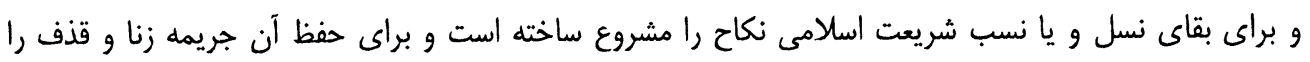

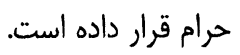

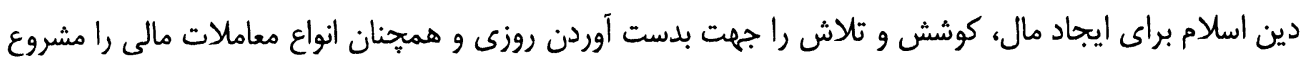

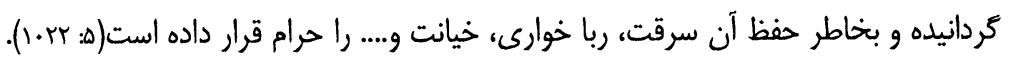

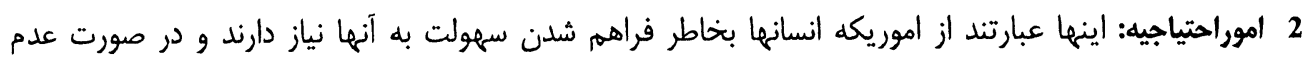

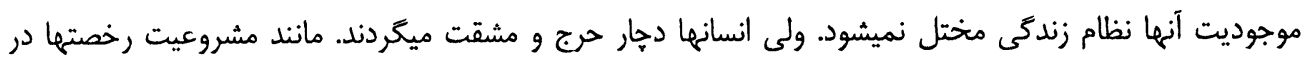


زمنيه عبادات، اباحت استفاده از خوردنيها و يوشيدنيها درعرصه عادات، اباحت عقود مانند بيع، اجاره، شركت، ضمانت و غيره.

در بخش معاملات، اعطاى حق عفو از قصاص براى ولى مقتول، تحمل ديت و خونبها توسط اقارب و خويشاوندان، دفع حدود به شبهات در زمينه عقوبات.

3- امورتحسينيه: امور تحسينيه عبارتند از اموريكه مروءت انسانى مقتضى آن است و در صورت عدم موجوديت آنها

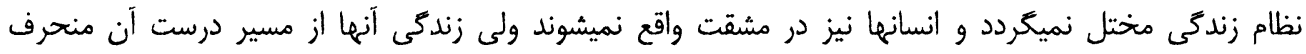

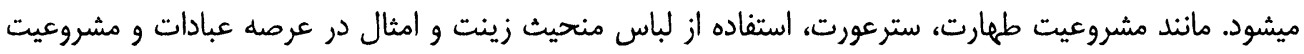
امتناع از بيع اشياى نجس و مضر، ممنوعيت بيع انسان بربيع انسان ديگر و نامزدى انسان بر انسان ديخرى در در زمينه

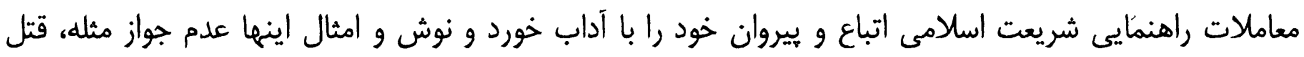

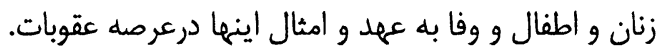

از آنجه كفته آمديهم جنين بر ميآيد كه مصالح انسانها به سه دسته از امور ضروريه، احتياجيه و كماليه تعلق كرفته

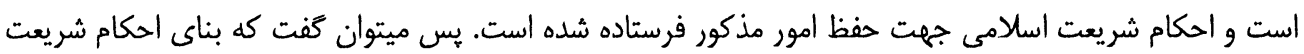
اسلامى بر اساس قاعده"جلب مصلحت ودفع مفسده" قانون گذارى شده است.

3- حجت بودن مصالع مرسله:

در ارتباط به اينكه آيا مصالح مرسله مصدر مستقل تشريع در نظام حقوقى اسلام محسوب ميشود و يا خير؟ فقهاء اختلاف نمودهاند.

الف- جمهورفقهاء: جمهورفقهاى اسلام بدين باوراند كه مصالح مرسله يكى از منابع تشريع ميباشد و به اين ارتباط

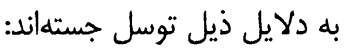

1 - به استقراء ثابت شده است كه مصالح مردم و جامعه به وجه احسن و بهتر در احكام و نصوص شرعى مراعات كرديده است و اعتبار جنس مصالح در مجموعه از احكام شرعى ايجاب آنرا ميكند كه اعتبار مصلحت

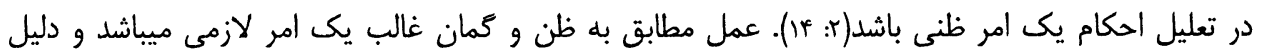

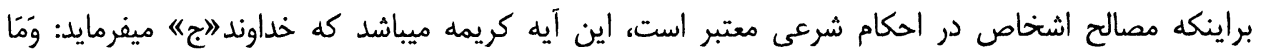

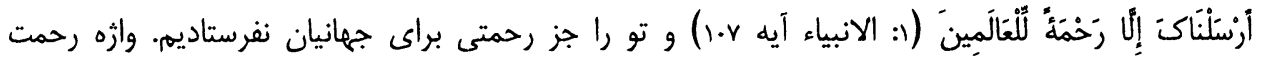
متضمن مصالح بندكان ورفع اضرار از آنها ميباشد. r - در حديث مشهور آمده است كه بيامبر(ص) اجتهاد بالرأى معاذبن جبل را زماينكه او را منحيث قاضى به فيه يمن فرستاد تأييد كرد و اجتهاد بالرأى تنها شامل قياس نميشود، بلكه تطبيق قواعد شريعت اسلامى را ذا ذريعه 
مقاصد عمومى آن براى تحقق بخشيدن به مصالح بندكان نيز احتواء ميكند و اين در حقيقت مصالح مرسله ميباشد.

r - صحابه كرام مصالح مرسله را قبول كردند و بسيارى از احكام شرعى را طبق آن ايجاد نمودند(F: ه.r). يس عمل صحابه كرام به مصالح مرسله بدون انكار از طرف يكى از آنها در واقع اجماع ايشان راد در مورد معتبر

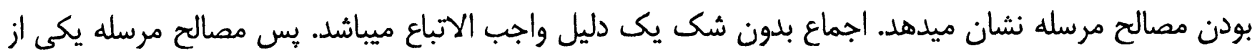
مصادر تشريع در اسلام است.

ب- برخى ازفتهاء: اينها به اين نظرند كه مصالح مرسله يكى از منابع تشريع شده نميتواند و به اين ارتباط به دلايل ذيل توسل جستهاند:

ا- شارع(خداوندج -) حكيم بوده و هيج جيزى را فرو كذاشت نكرده است. بلكه هر آنحه را كه به به مصلحت

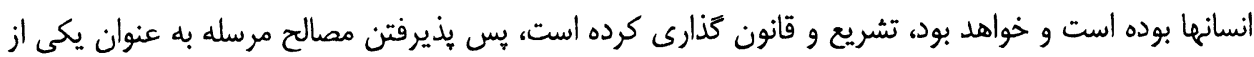

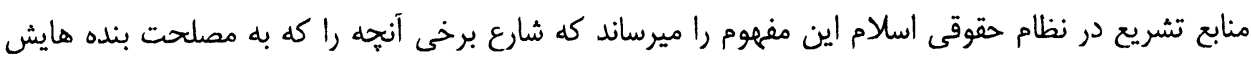

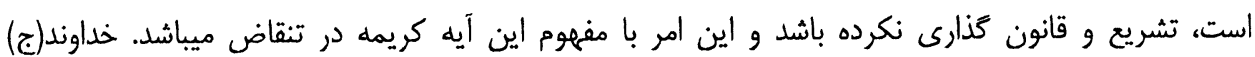

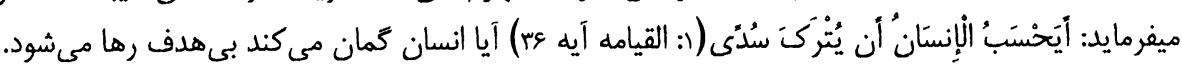

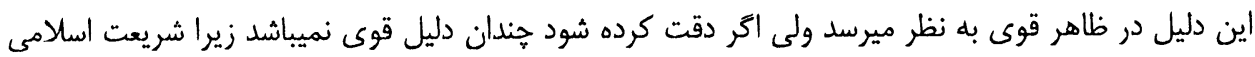

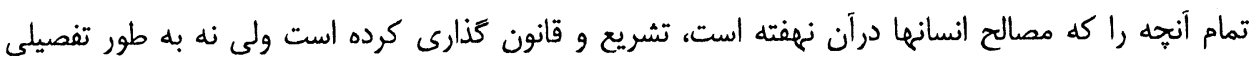

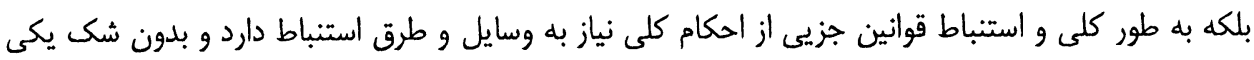
از وسايل و ميتودهاى استباط احكام جزيى مصالح مرسله ميباشد.

ז- مصالح مرسله در بين مصالح معتبره و مصالح ملغائ متردد است والحاق آن به مصالح معتبره نسبت به به بهال مصالح ملغأ بهتر نخواهد بود زيرا استدلال به مصالح مرسله بدون دليلى كه بر معتبر بودان بودن آنها دلالت نمايد، ممتنع خواهد بود.

اين دليل نيز ضعيف ميباشد زيرا اصل در شريعت اسلامى مراعات مصلحت است و الغاى مصلحت به مثابه يك

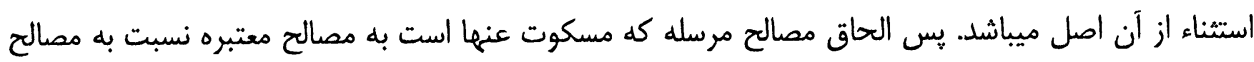
ملغائ بهتر خواهد بود.

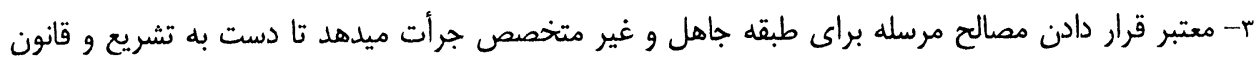

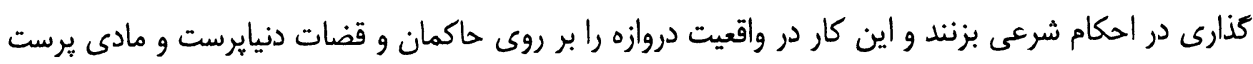

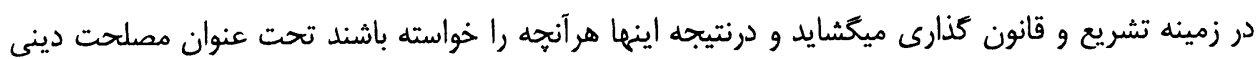

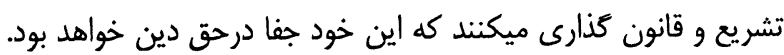


در ارتباط به رد اين دليل ميتوان كفت كه تشريع و قانون كذارى احكام با استفاده از مصالح مرسله زمانى اعتبار دارد

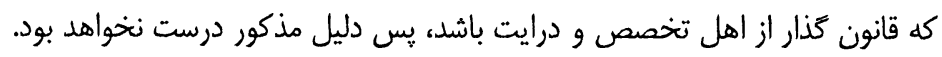

\section{ب-ترجيحنظيد جمهور:}

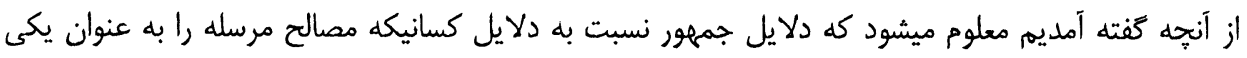

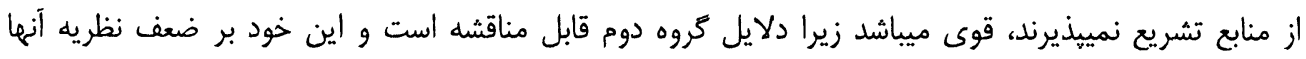

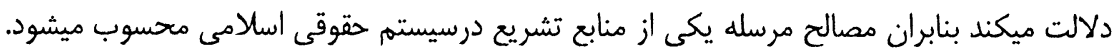
احكاميكه بناى آنها را مصالح مرسله تشكيل ميدهد: برخى از احكام شرعى كه توسط صحابهُ كرام طبق مصالح مرسله ايجاد كرديدهاند قرار ذيل ميباشند:

ا -- جمع آورى قرآن كريم از مصاحف متفرقه در مصحف واحد توسط حضرت ابوبكر صديق(رض) به مشوره حضرت عمر(رض). r - - صدور فرمان جنگ در مقابل مانعين زكات توسط ابوبكر صديق(رض).

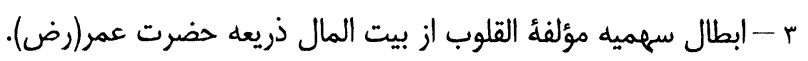
r - اسقاط حد سرقت در سالماى گَرسنگى ذريعه حضرت عمر(رض). هـ قتل يك گروه در برابر قتل يك نفر، هنگًاميكه آن گروه در قتل وى اشتراك ميداشتند بواسطه حضرت عمر(رض)

צ- حساب نمودن طلاقهاى سه كانه به لفظ واحد، طلاق ثلاثه ذريعه حضرت عمر(رض). v - كذاشتن زمينهايى كه بزور فتح شده بودند در نزد صاحبان آن و وضع خراج بر آنها توسط حضرت عمر(رض)

^ - تزويد بيت المال، تدوين ديوانها و تأسيس زندانها توسط حضرت عمر(رض).

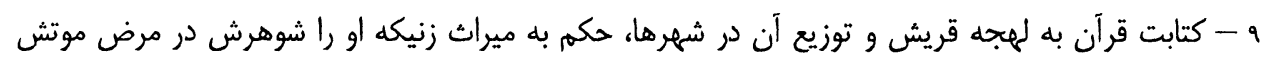
طلاق ميكرد توسط حضرت عثمان(رض). . - اتفاق صحابه بر اينكه صنعتكران درصورتيكه اموال مردم را كه در نزد آنها است تلف ميكنند بايد ضمانت بيردازند (D: (v\&4). در ارتباط به اينكه آيا مصلحت مرسله مخصص نص غير قطعى الدلاله ميتواند واقع شود يا خير؟ كسانيكه قايل به حجت بودن قاعده استصلاح هستند دراين زمينه اختلاف كردهاند. 
از نظر فقهاى حنبلى، نص غير قطعى الدلالة توسط آنجه را كه مصلحت مرسله ايجاب ميكند تخصيص نمى إبد

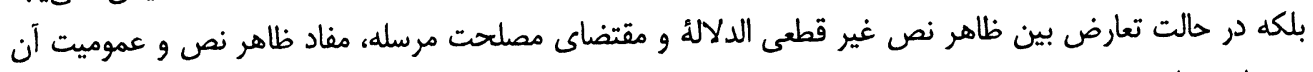
بر مفاد مصلحت مقدم ميباشد(ع. بو).

اما از نظر فقهاى حنفى و مالكى در وقت تعارض مصلحت ميتواند مخصص نص غير قطعى الدلالهُ واقع شود زيرا

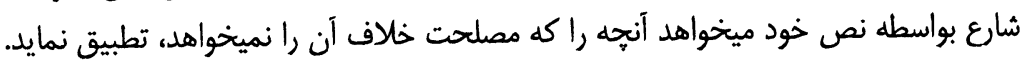

\section{4 - انظيـنه مساجعت به مصالح مـسله درايجاد احكامجديد:}

عوامل و فكتورهاى مراجعت به قاعده استصلاح و مصالح مرسله را در تأسيس احكام جديد كه داراى ويثزى

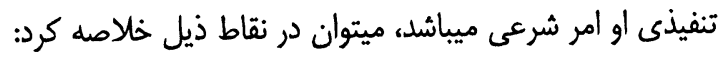

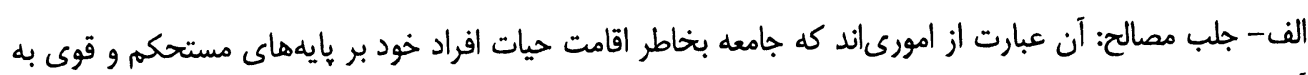

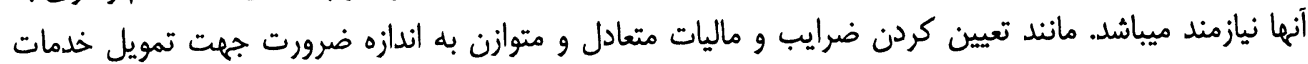
عامه و يروزمهاى سودمند.

ب- دفع مفاسد: آن عبارت از امورىاند كه از لحاظ مادى و يا معنوى براى فرد و يا جامعه مضر واقع گردند. ج- سدالذرايع: آن به معناى مسدود ساختن راههايى است كه منجر به اهمال و يا حيله قرار دادن احكام شريعت اسلامى و يا وقوع محذورات شرعى قصدا و يا سهروا ميخردد.

د- تغيير زمان و مكان: يكى ديكر از انكيزههاى رجوع به مصالح مرسله در ايجاد احكام تازه اختلاف احوال و اوضاع

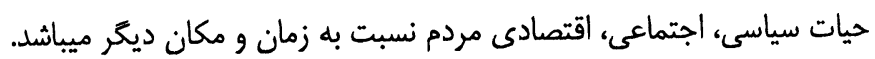

مفهوم و مثالهاى دو انكيزه اول براى رجوع به قاعده استصلاح يعنى جلب مصلحت و دفع مفسده را بيان نموديم و

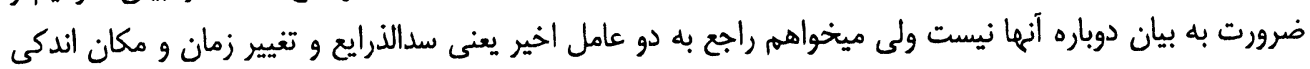
توضيحاتى داشته باشه.

ذريعه در لغت به معناى وسيلهيى كه انسان جهت تحقق بخشيدن به هدفى و يا كارى از آن استفاده ميكند آمده

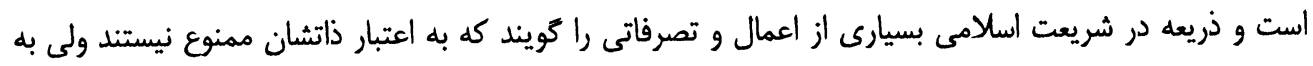

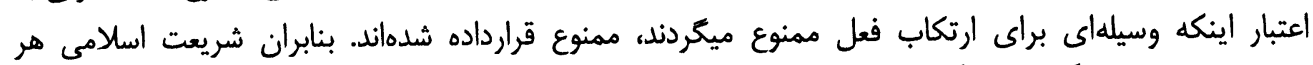

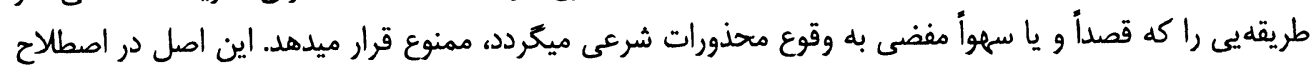

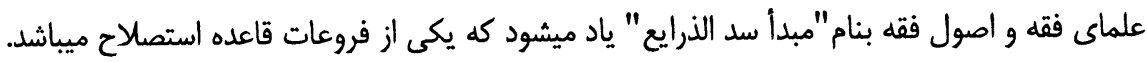
راجع به اينكه مبدأ سدالذرايع از جمله عوامل رجوع به مصالح مرسله در تأسيس احكام جديد ميباشد نصوصى از

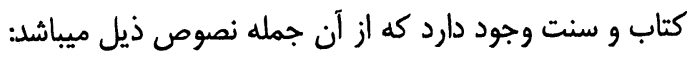




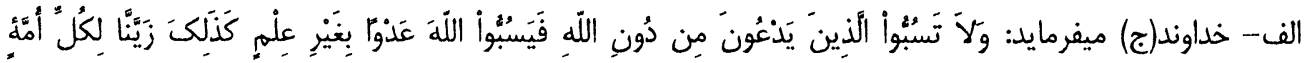

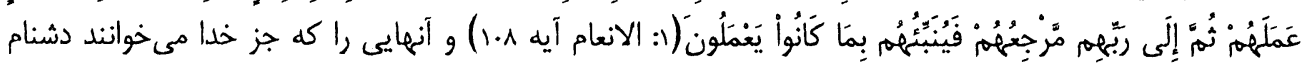

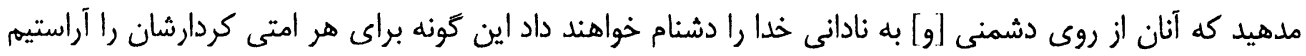

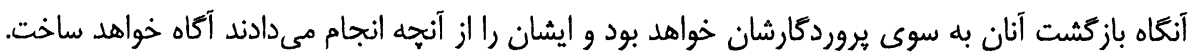
در اين آيه ديده ميشود كه خداوند(ج) از دشنام دادن به كفار نهى ميكند زيرا اين عمل بان باعث اين امر ميشود كه آنها

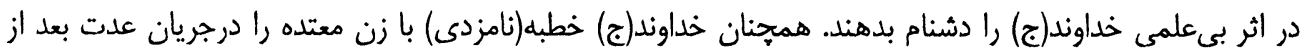

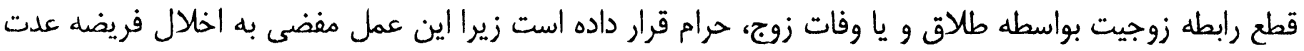
كه داراى اهميت بوده و از مقتضيات نظام فاميل و حقوق زوجيت قبلى ميباشد، ميكردد. ب- بيامبر(ص) از اعمار مسجد در قبرستان نهى كرده است تا مبادا اين كار باعث عبادت و يرستش قبرهاى بزركان 5رد.

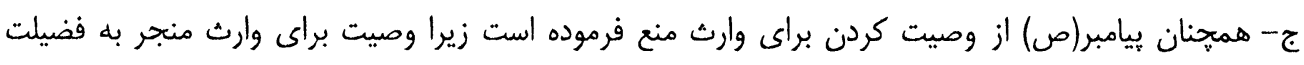

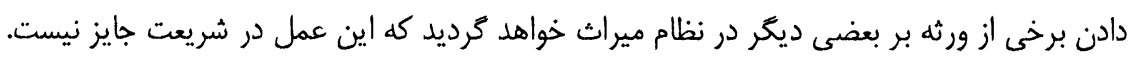
د- همجنان رسول الله(ص) از خلوت نشستن با زن اجنبيه نهى نموده است بخاطريكه خلوت با اجنبيه ذريعه وقوع فساد ميباشد.

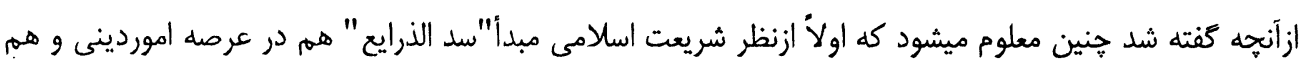

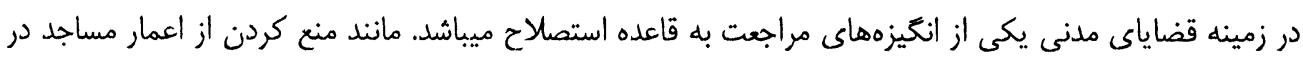

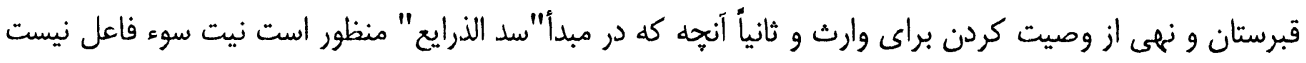

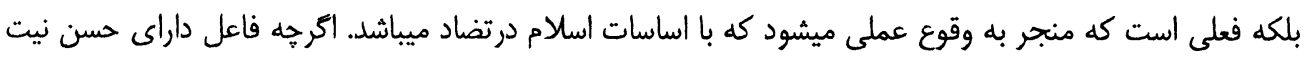

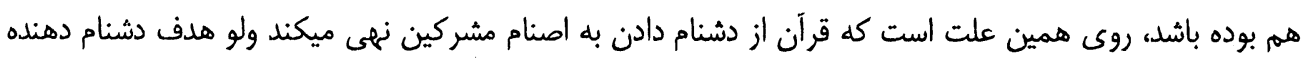
ايمان به خدا و كمك به دين اوتعالى بوده باشد.

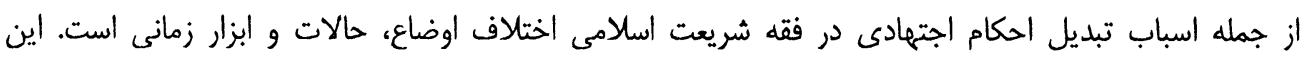

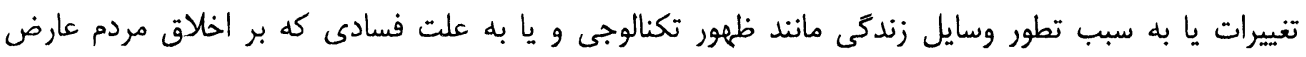

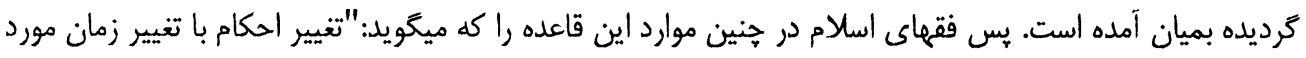
انكار قرار نميخيرد"(" ماده و جr).

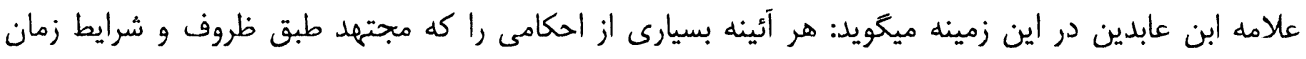

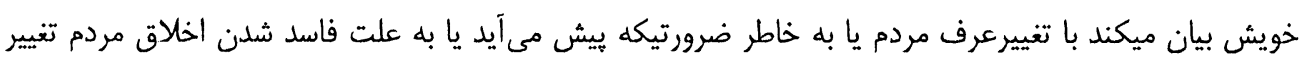

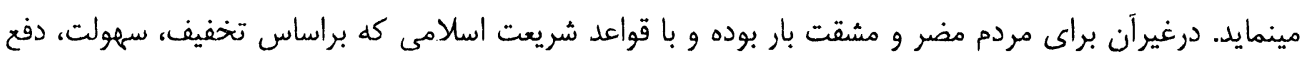

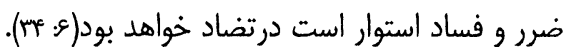




\section{-5 - احكاميكه براساس مصائح مسله ايجاد ميكردند:}

احكاميكه بر اساس اين قاعده وضع ميكر دند به دو نوع تقسيم ميشوند:

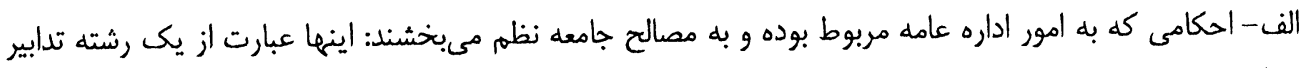

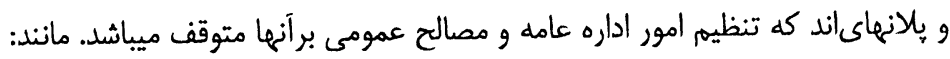

$$
\begin{aligned}
& \text { 1- مجهزساختن سيستم دفاعى با وسايل مدرن نظامى. }
\end{aligned}
$$

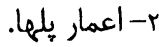

$$
\begin{aligned}
& \text { r- احصائيه نفوس. }
\end{aligned}
$$

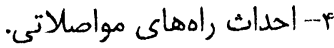

$$
\begin{aligned}
& \text { هـ- تأسيس شفاخانه ها. } \\
& \text { 9- تعيين ماليات بر ثروتمندان. } \\
& \text { v- تجديد بانك نوتهاى رايج دركشور در صورت ضرورت. } \\
& \text { 1- ساير يروزههاى تضمين اجتماعى. }
\end{aligned}
$$

بـ- احكامى كه به امور قضايى و حقوق خصوصى ارتباط ميكيرند: اين نوع احكام در دو عرصه يكى امور قضايى و ديگرى امورحقوق خصوصى مى باشند:

الف- مثالهاى واقعى درعرصه امور قضايع قرار ذيلاند:

1-- تأسيس قضاء ادارى جهت بررسى شكايات از عملكرد مقامات حاكمه.

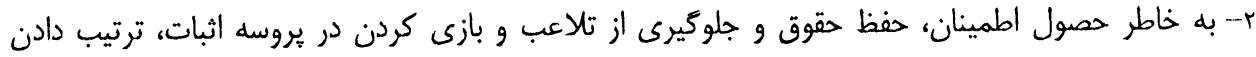

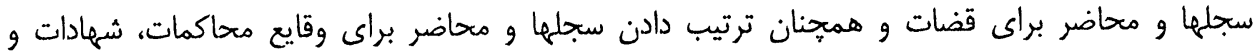

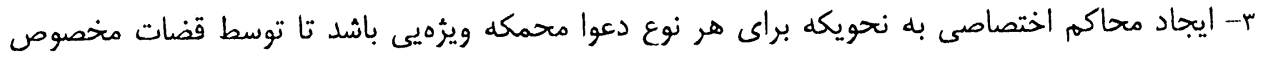

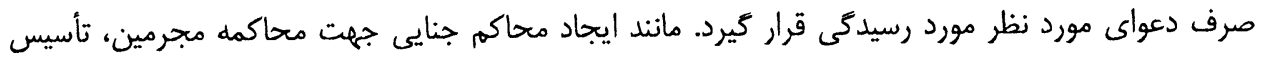
محاكم مدنى به هدف رسيدگى قضاياى مدنى.

†- تأسيس محاكم ابتدايى، مرافعه و تمييز جهت جلوكيرى از حق تلفيها. 
هـ منع نمودن قضات توسط امر رئيس دولت، يا فتواى فقهاء از شنيدن دعواهايى كه مدت طولانى از طرف

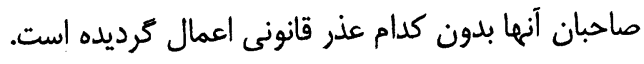
ب- مثالزهاى واقعى درعرصه حقوق خصوصى قرار ذيلاند:

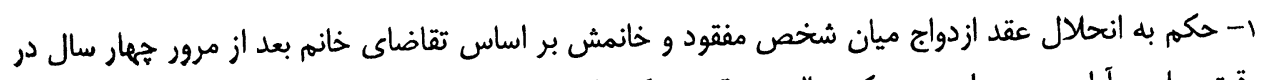

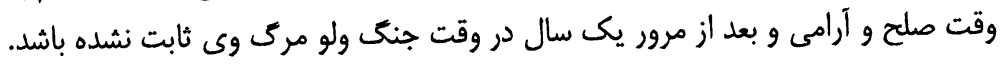

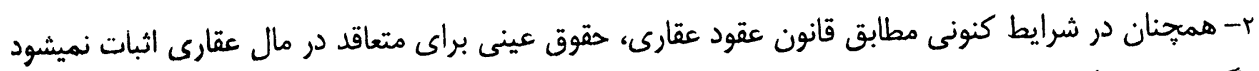

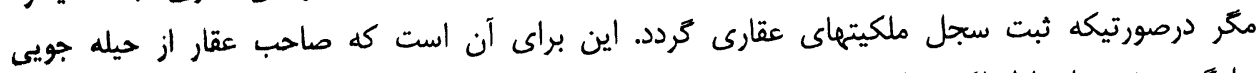

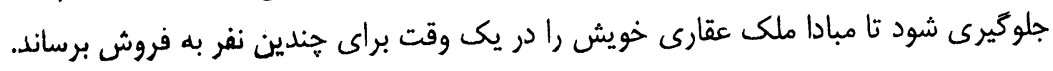

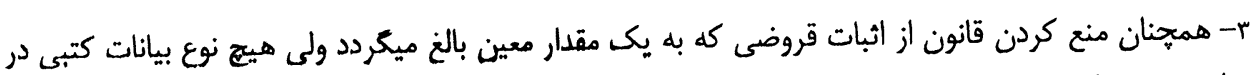
ميان وجود ندارد.

\section{6- ثـوطوعل به مصائح مرسله:}

از نقطه نظر فقه اسلامى بويزه فقه مالكى عمل به مصالح مرسله داراى يك سلسله شروط ميباشد كه آنها عباتند از:

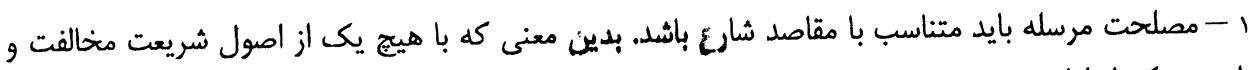
با هيج يك از ادله شرعى منافات نداشته باشد. r- مصلحت مرسله بايد بخاطر خفظ يك امر ضرورى يا رفع يك حج و مشقت باشد. r- مصلحت مرسله بايد معقول باشد يعنى عقل سليم آن را بيذيرد. + - مصلحت مرسله بايد مصلحت حقيقى باشد نه يكى مصلحت و همى و خيالى. هـ - مصلحت مرسله بايد عمومى باشد نه خصوصى(1) بـr).

\section{7- ساحت عمل به مصالح مسله:}

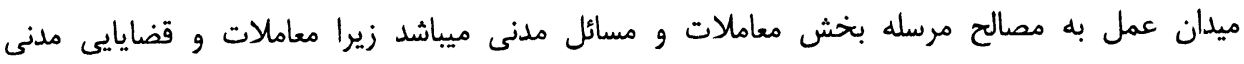

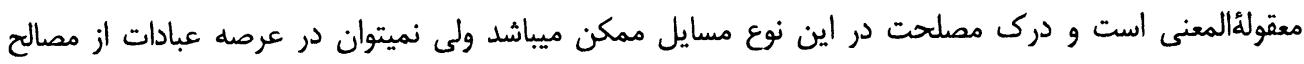

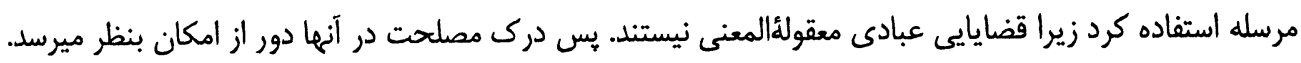


از آنجه كفته آمديم نتايج ذيل مىبر آيد:

ا - تشريع در سيستم حقوقى اسلام دو نوع منابع دمايع دارد يكى منابع اصلى و ديكر منابع تبعى كه مصالح مرسله از جمله مصادر تبعى آن ميباشد. r- قاعده استصلاح به اعتبار اينكه با مقاصد اسلام در تضاد نيست معيار امر و نهمى در شريعت اسلامى ميباشد نه به لحاظ معناى ذاتيش.

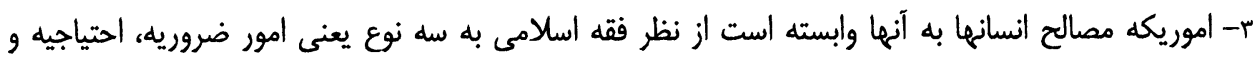
تحسينيه تقسيه ميشود.

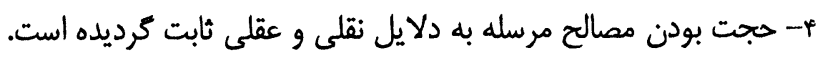

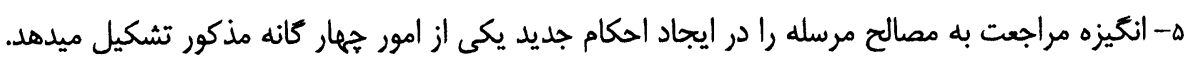

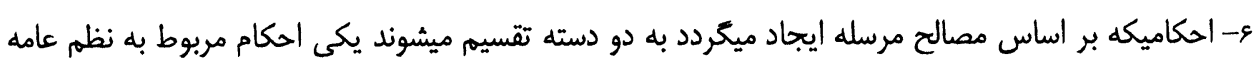

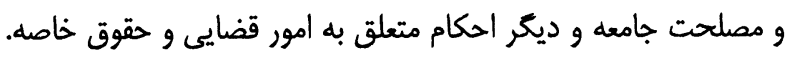

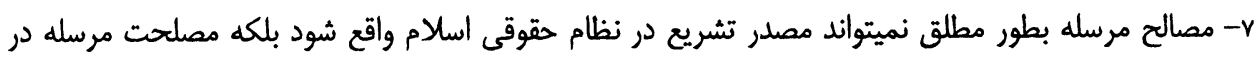

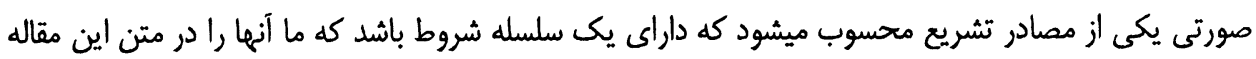
ذكر كرديهم.

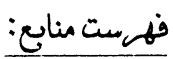

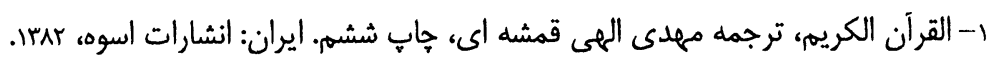

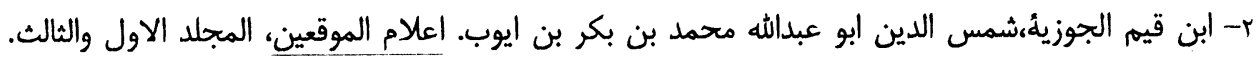

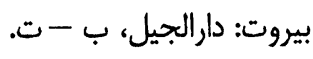
r- الاتاسى، محمد خالد وابنه محمد طاهر. شرح مجلة الاحكام العدلئ. سوريه- حمص: دارالكتب العلميه، sirar

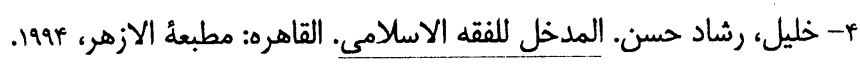

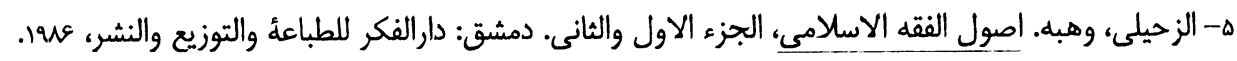

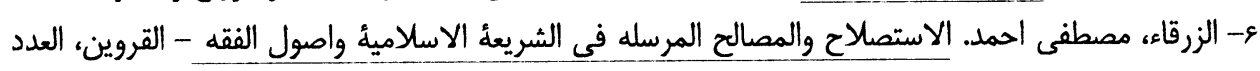

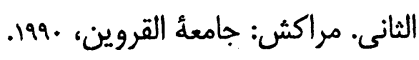

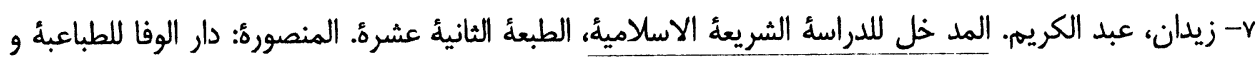
النشر والتوزيع، كوان،

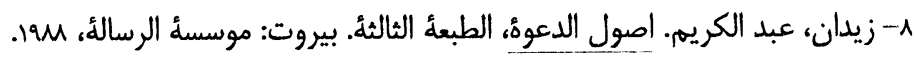




\section{دوستار نامي د اشعارو شكلي}

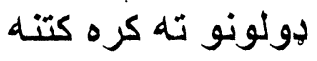

سريزه:

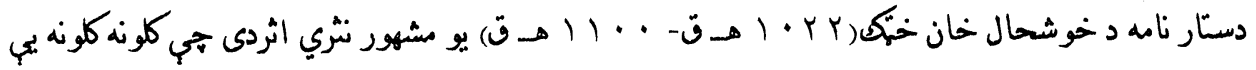

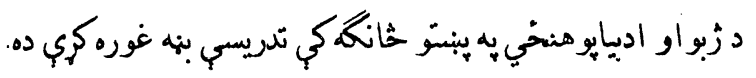

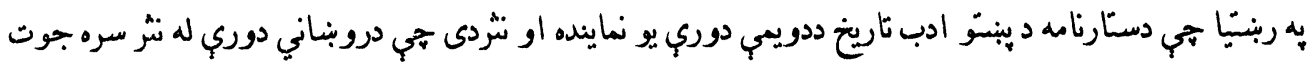

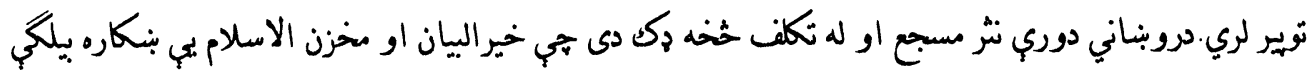

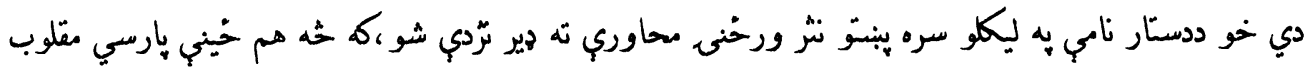

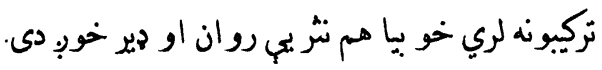

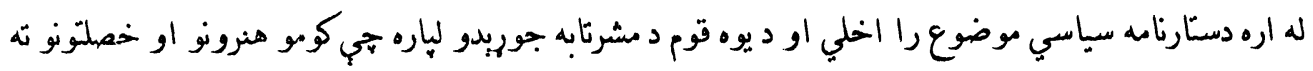

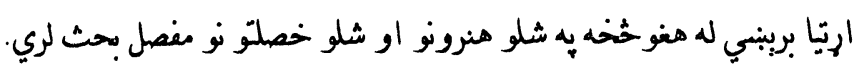
لومي ياد شويو هنرونو ته د فرضو ،وريسي د واجبو ،وريسي د سنتو او يه دي بسي د مستحبو مرجه وركمل شوي

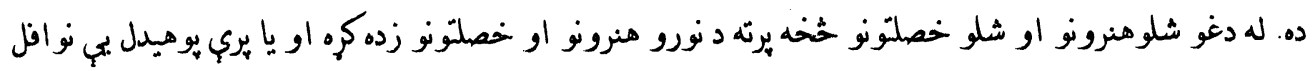

باوري خبره دهك خوك د قوم مشري به غاره اخلي نو به دغو هنرونو او خصلتونو بايد خان يوه او سنبال كمي.

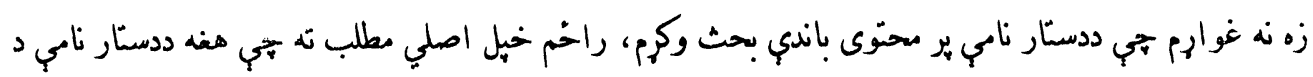

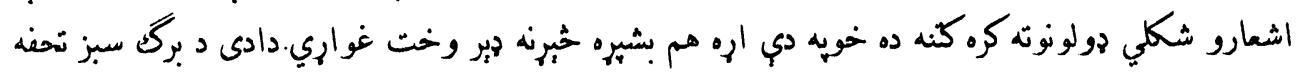

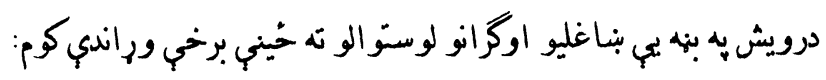
ددستارنامي داشعارو وزن او دشكلي هولونوسيرنه خوشحال خهتك ددستارنامي دليكلو لامل د ابيتكي: 


\section{هي دستار تري هزار دي ددستّار سري به شمار دي(ب : ().}

دغه بيت به فراقنامه كي راغلى او ذوالقافتين دى(9: • r () ،لومرى قافيه بيج(تري او سري)او دويمه قافيه

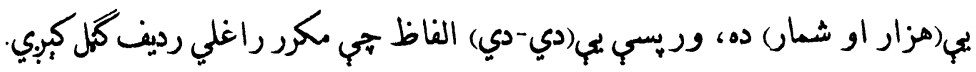

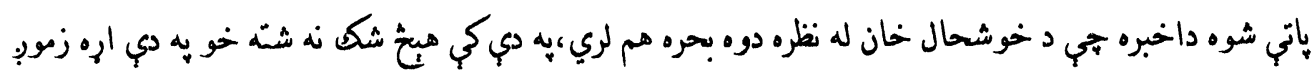

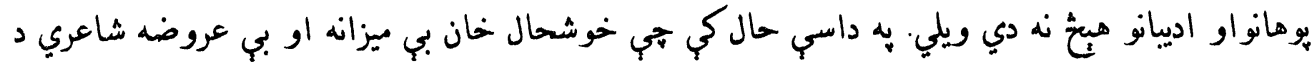

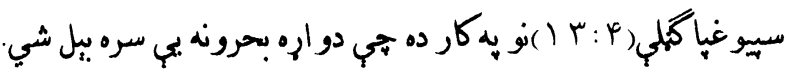

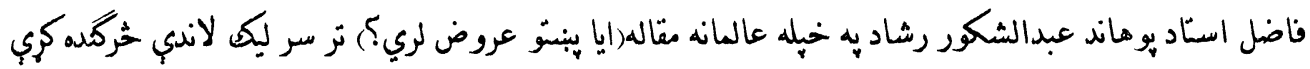

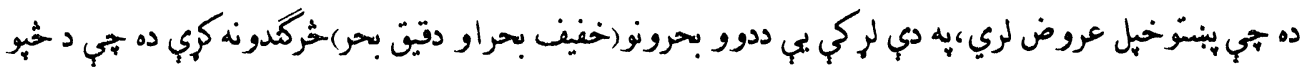
هه شمبره خفيف بحر اته خيز او دقيق بحرديارلس خيّز او خوار لس حثيز راورل شوي دي خوله نورو دي مول

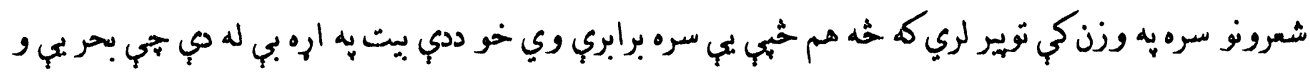
نوموي داسي ليكي:

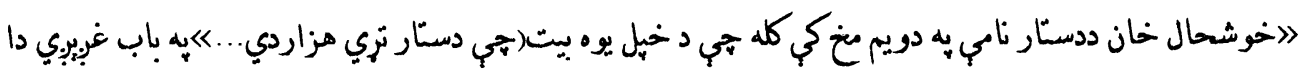
عموميت لري كوي او به خركد هول سره دفراقنامي يو نظم جي ذكر شوى بيت د هغه جزدى به كوم بحر يوري ترلى

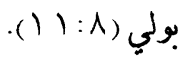

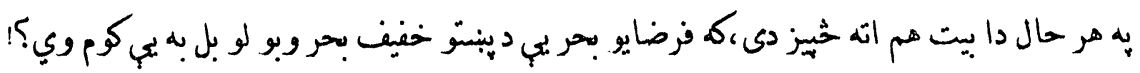

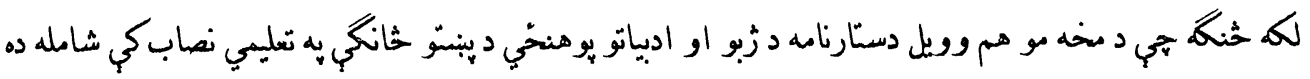
نو يهكار ده هي دغسي غوني يراسمّل شي او محصلين به تباروكي نورلاس او بنبهي و نه وهي.

سريره هير دي هي خوشحال خان يباورى شاعر او يو متبحر عالم هم و او داورته هيره ساده خبره وه هي د شعر

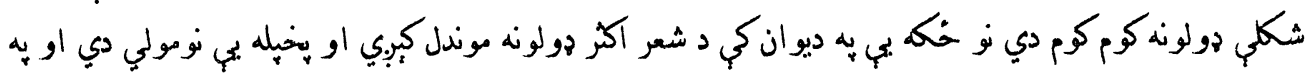

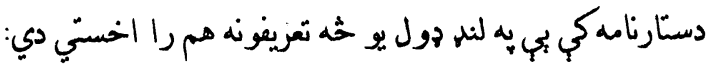

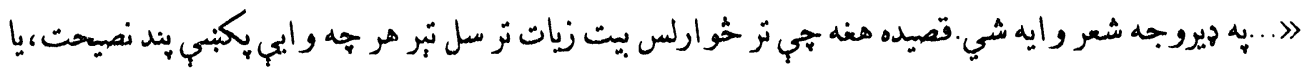

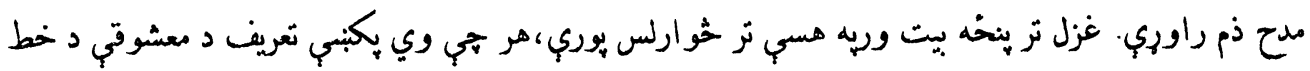

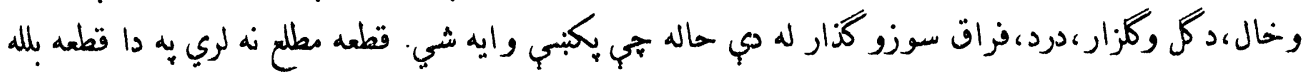


شي،كة دوه بيته اوره اته لس شل هر جي وي،رباعي هنه هي دوه بيته وي، مخمس بنخه مصرعي، مسدس

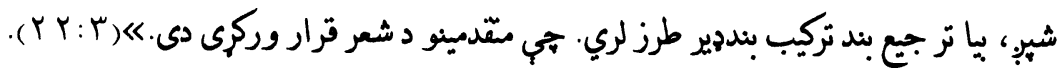

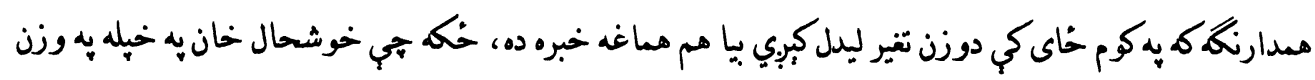

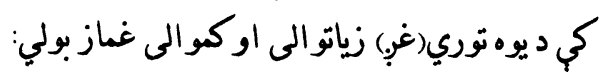

$$
\begin{aligned}
& \text { لكه غشي لره بويد تير انداز } \\
& \text { هسي شعر لره بويه سحر ساز } \\
& \text { همبشه د زره بـ لاس تله د وزن }
\end{aligned}
$$

زيات وكم دوزن يو تورى غماز (ه :4 ب (1).

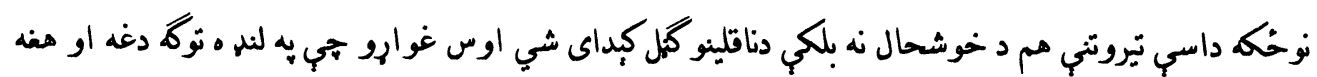

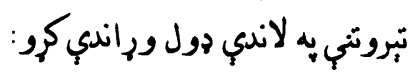

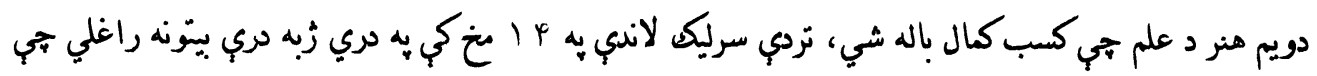

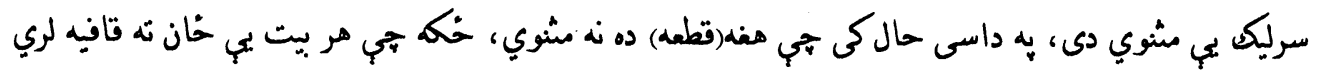

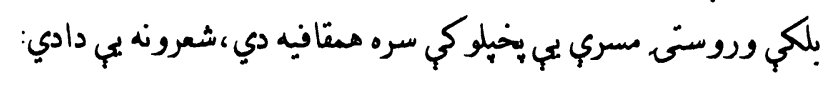

$$
\begin{aligned}
& \text { وقى افتاد فتنه در شام } \\
& \text { هركس كوشه فرار فتند } \\
& \text { بران وزير ناقص عقل } \\
& \text { بكا بي بروستار فند } \\
& \text { روستا زادكان دانشسند } \\
& \text { بوزيري به بادشاه رفتد }
\end{aligned}
$$

دغه قطعه ددري زبي د مشهور شاعرسعدي يهكلياتوكي بي سر ليكه داسي راغلي: 


$$
\begin{aligned}
& \text { وقتى افتاد فنه در شام }
\end{aligned}
$$

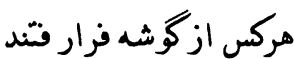

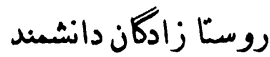

$$
\begin{aligned}
& \text { بـ وزيرى بادشاه رفند } \\
& \text { بسران وزير ناقص عقل }
\end{aligned}
$$

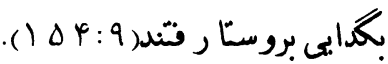

كت متّ همدغه تِروته ددستار نامي به اردو زبارنه كي هم ليدل كُبِي او لوري يادي شوي(قطعي)ته بي مشوي

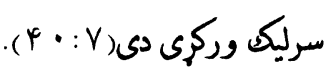

$$
\text { توقابل اى كه ستاره بیى سعاد تمند دا(فرد)راغلى: }
$$

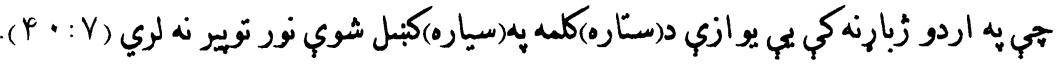

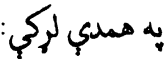

$$
\text { كا ناستى د ناقل يه سرير ياس وي }
$$

$$
\text { به معني كي خندان خان شاه عباس دى(ب :4 (1). }
$$

به دي(فرد)كي باس او عبام)د قافيب كلمي دي او وريسي(وي او دي) رديف نه شي كيداى ،يه اردو زبارينهي بيجي

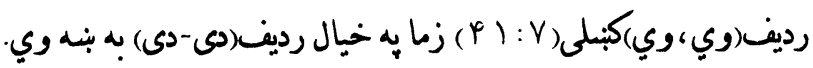

$$
\begin{aligned}
& \text { هيت صيقل نيكو نخواهدكرد } \\
& \text { اهنى راكه بدكو هر باشد(ب :9 (1). } \\
& \text { د سعدي بدكلاتوكي دا بيت داسي راغلى دى: }
\end{aligned}
$$




\section{هيج صيقل نكو نداندكرد}

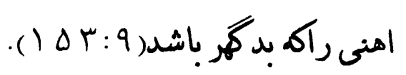

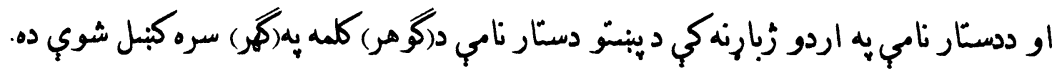

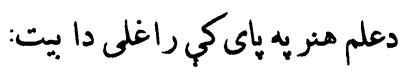

$$
\begin{aligned}
& \text { علم معشوقه دى معشوقي لرهك بويه }
\end{aligned}
$$

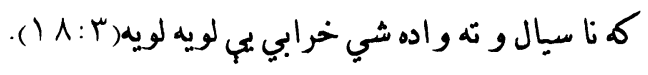

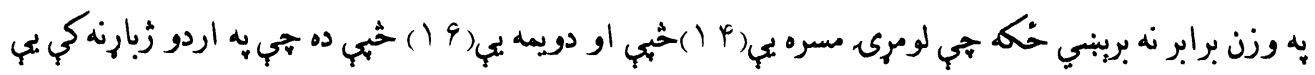
دويمه مسره داسي كبنلي ده:

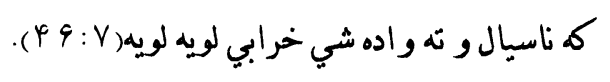

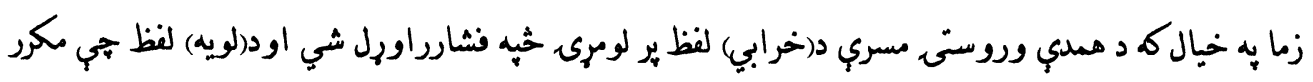

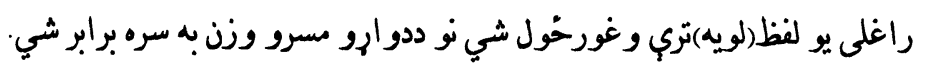

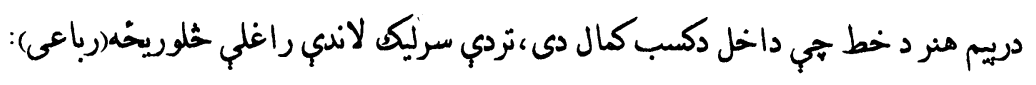

$$
\begin{aligned}
& \text { خط خوب ایى يسر بس دليذير است } \\
& \text { جوروح اندر تن بر ناو ير است } \\
& \text { آكممنعم بود ارايش اوست }
\end{aligned}
$$

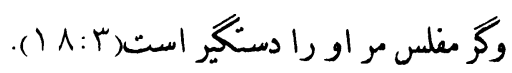

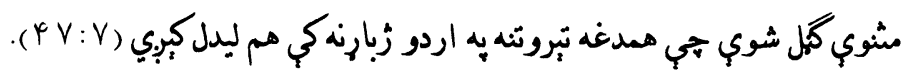

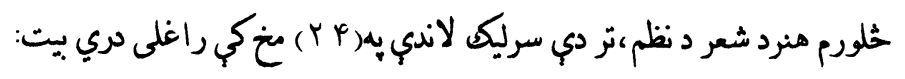

$$
\text { براى بآكى لفظى شبى بروز ارم }
$$

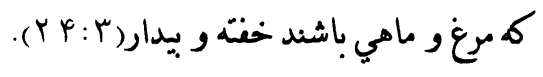


ددستار نامي به اردو زبارنهمي يبي هم كتّ مت دغه بيت همداسي را نقل كمى دى خو يه بايليك كي بي زياته كي ده

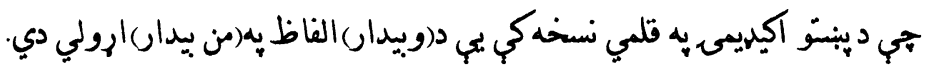

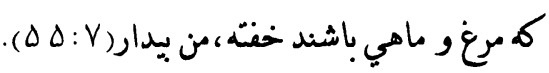

زما به خيال دا يوه بنه بي هم سمه نه ده او الطاف حسين حالي به خيل اثر(مقدمه شعر و شاعري) كي دا بيت داسي كبنلى دى:

براى بآكى لفظ شبى بروز ارد

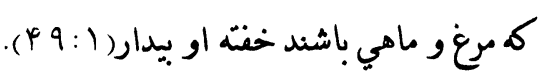

هي همدغه بنه بيج سمه برينبي او بنه مفهوم تري راوخي نه به نورو بنو.تر نوموري سر ليكك لاندي راغلي رباعي: كه شعردى هغه دى جي يبي ورايي دانا هغه خه شعر نه دي جي يجي جوركاندي كانا دواره توكه خده دي درته وايمهه معني يو اواز د خره دى بل اواز مى دسرنا(ب :ه r).

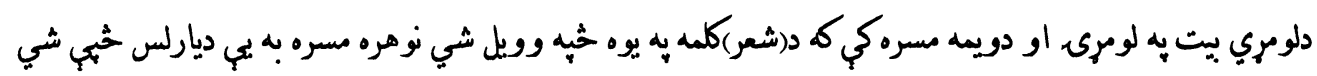

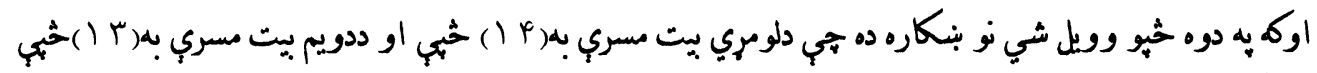
شي هي به دي صورتكي به به ونكي بدلون راشي.

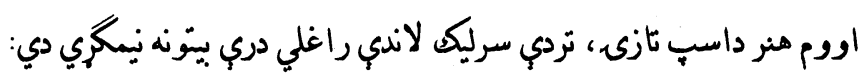
اسب شاهان كميت بايد خنك كردن او دراز وكوته لنك كردن لنك است اماكيت يا

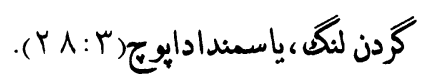
به اردو زبارنهكي داسي راغلي: 
اسب شاهان كيت بايد و خنك

كردن او رراز وكوته لنك

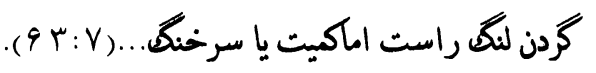

يوه مسره نيجكه ده

او هماغه دكابل جاب دا نظريب تايدكمى دى جي دا عبارت نيمكرى دى.

هم هنر د شجاعت،تر دي سرليكك لاندي راورل شوي منوي ، رباعي كمل شوي:

رباعي:

سوى مشرق دو شنبه و شنبه

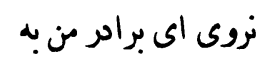

انكه مر مغرب اوردينه

روز يكسنبه است و ادينه

روز سه شنبه و جهار بفال

نروى زينهارسوى شمال

روزينجشنبه اي نكو اختر

رخت خود جانب جنوب مبر(r : 9 ٪).

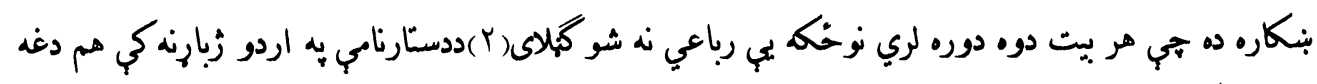

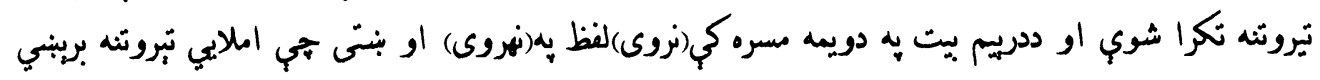

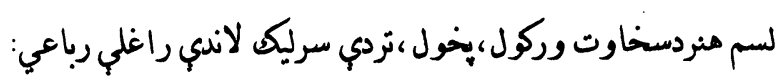

هي حتبري اشنابح حير يارانكا 
بادبشونه به خيل خانكا

$$
\text { اشنابح, عالم خواركم }
$$

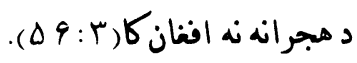

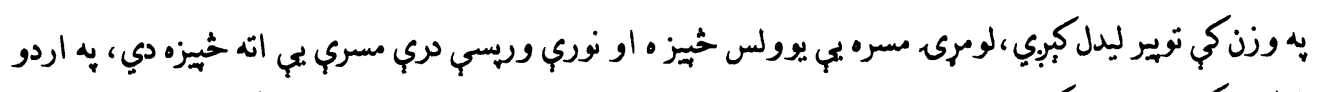

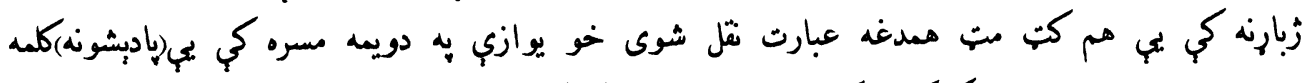

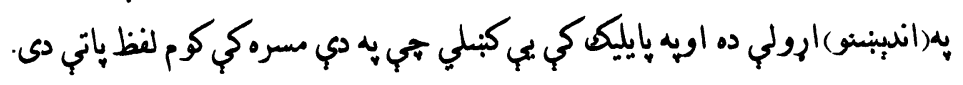

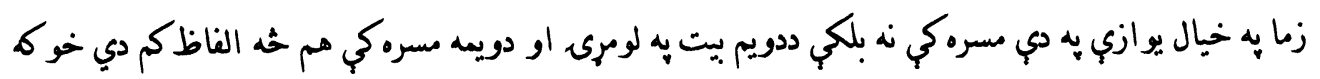

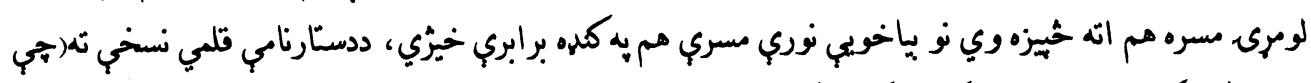

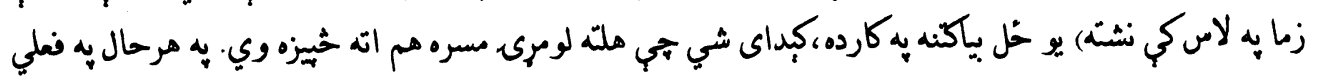
بنه بي به وزنكي توير ليدل يُبري. اتلسم هنر دعلم موسيقي، تر دي سرليك لاندي راغلي رباعي ته هي خملور واره مسري بي هم قافيه دي د مثنوي

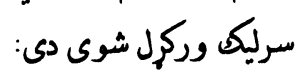
منوي: رقص ان نبودكه هر زمان برخيزي به مرد هو كرد از ميان بر خيزى رقص ان باشدكر دوجهان برخيزى

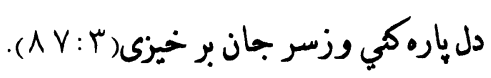

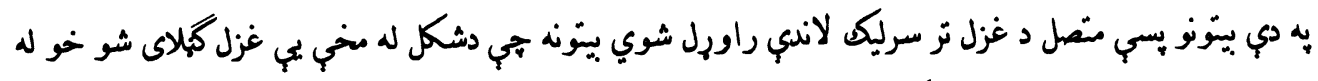

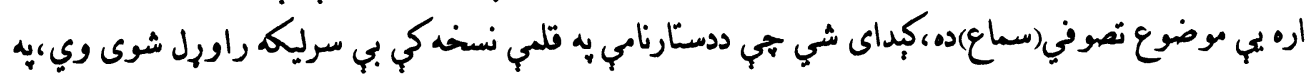

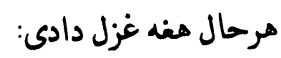
واى برين مدعيان سماع 


$$
\begin{aligned}
& \text { وجدكند از سر تقس اختراع } \\
& \text { جشم كماده بسوى اسمان } \\
& \text { سته دل خود بضياع و متاع } \\
& \text { وقت تجمل همه هدهون جنيد } \\
& \text { وقت تحمل همه همهون سباع } \\
& \text { ردد دل خوبش بكويم ترا } \\
& \text { از غم اين قوم بكن استماع }
\end{aligned}
$$

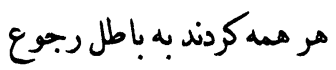

$$
\begin{aligned}
& \text { هرهمه كردند ز تثوى وداع } \\
& \text { هركه مر و يروي شرع نيست } \\
& \text { وسوسهء ديو بودبى نزاع } \\
& \text { نست رين قومكس اهل وجد } \\
& \text { نيست درين دايره مرد سماع(ب (A V: ). } \\
& \text { يورته كنبل شوي بيّونه به اردو زبارنهكي بب سرليكه راورل شوي دي. }
\end{aligned}
$$

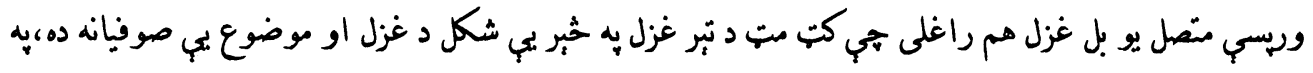

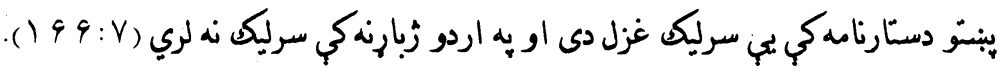
به همدي لركي دابيات)تر سرليكك لاندي دوه بيّونه راورل شوي جي لومرى دويمه او خلورمه مسره بي اووه

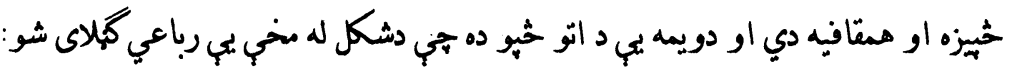

سرودهورته دى روا هي نه غاوري نه غوغا 


$$
\begin{aligned}
& \text { سامعان بي صاحبدل وي }
\end{aligned}
$$

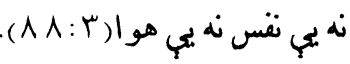

$$
\begin{aligned}
& \text { التم خصلت دعفو دكرم،تردي سرليك لاندي دابيّونه: } \\
& \text { برفت مرا نكشت اندر صفكين. } \\
& \text { با انكه بودمكتني ازروى بقين } \\
& \text { و انهة به طبن مبدهدم در ثمين } \\
& \text { بخشايش و بخششم هنين كرد بين(r :r • (1). }
\end{aligned}
$$

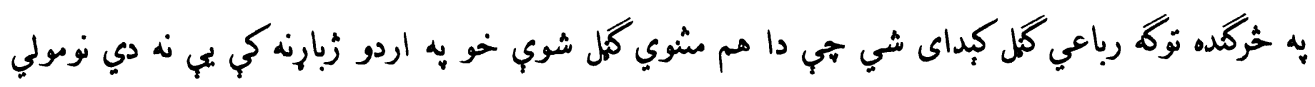
(اردو: : 9 () (له

لسم خصلت د عدل او انصاف دى،تر دي سرليك لاندي د(ابيات)تر سرليكك لاندي دا بيتونه:

$$
\text { بيغمبركة در عهد نوشبروان }
$$

برخ كثت جشم و جراغ جهان

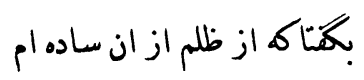

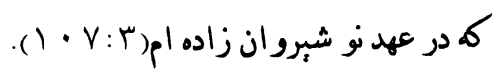

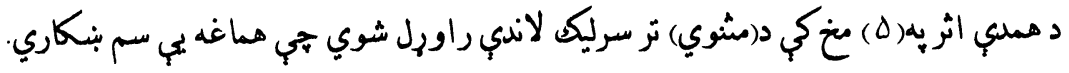

$$
\begin{aligned}
& \text { يو يسمب خصلت دثوكل دى، تر دي عنوان لاندي د(ابيات) تر سرليك لاندي دابيّونه: } \\
& \text { خويبي نه دى لاس له خبله خانه وللى }
\end{aligned}
$$

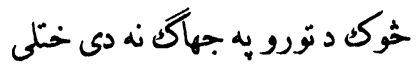

$$
\begin{aligned}
& \text { اول روغ به توكل كاد خان خخلى }
\end{aligned}
$$

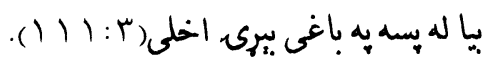




$$
\begin{aligned}
& \text { (ابيات) كمل شوي جي يه بنكاره بي د شكلي نولو نو له مخي رباعي كملاى شو. } \\
& \text { بنخلسم خصلت دهمت دي، تردي سر ليك لاندي ددي بيت: } \\
& \text { دستار نداريم غم هيج نداريم }
\end{aligned}
$$$$
\text { جون هيتج نداريم غم هيَّ نداريم(ب: (1) (1) }
$$

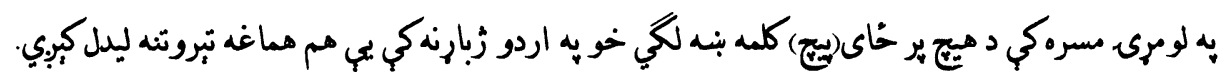
نولسم خصلت دورع دطاعت دعبادت دى، تر دي سر ليك لاندي رباعي ته د(قطع) عنوان وركمل شوى دى.

$$
\begin{aligned}
& \text { به زبانكي ديكارونه } \\
& \text { هم سودونه هم زيانونه } \\
& \text { كه له زيانه يب خلاصتبرج } \\
& \text { زه بي مه وينم سودونه(r : } 1 \text { () ). }
\end{aligned}
$$

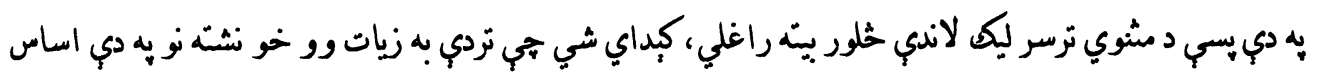
بي د غزل برخد هلاي شو نه مشنوي: بنه دلبره قاصرات الطرف ایى ياره به خيرات حسان جوره بنه ديداره

$$
\text { بهُبْاً به اترابًا سره بسندلي }
$$$$
\text { به حوراًا عيناً درست سرهكزاره }
$$$$
\text { خداى كه دا هسي دلبر و جاته وركا }
$$

بنايسته د جنت حوره شه تري جاره نه داهسي رنك يوه بهكوركي ناستة 


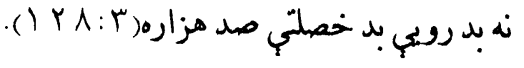

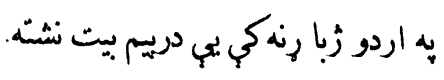

بإيله:

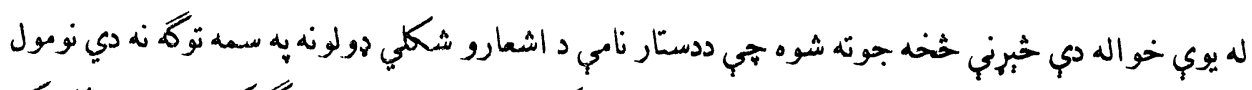

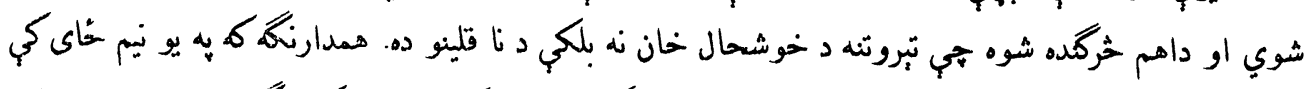

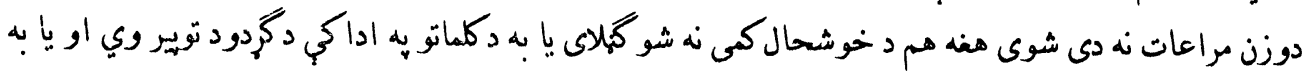

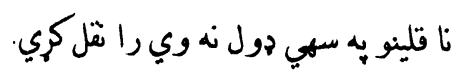

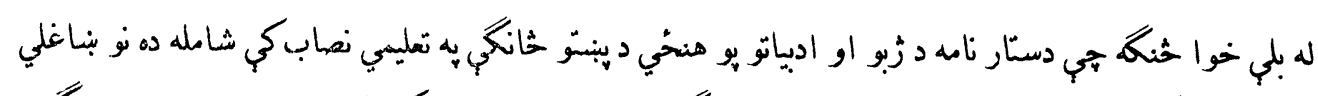

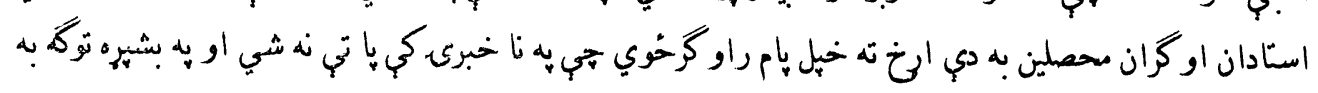

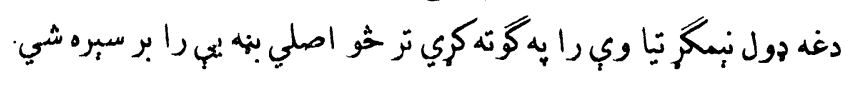

مُا خذونه

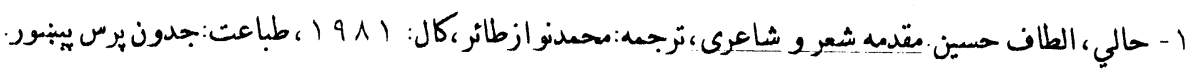

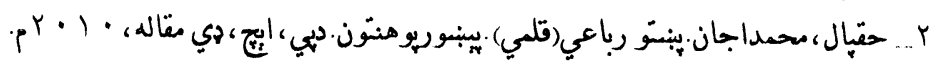

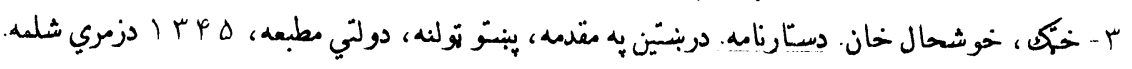

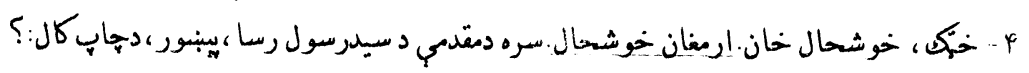

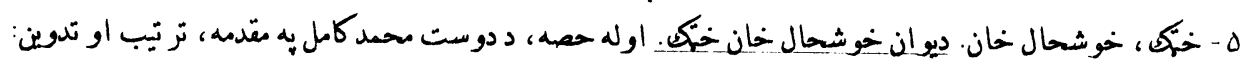
دحاجي يردل خهك ،كال:

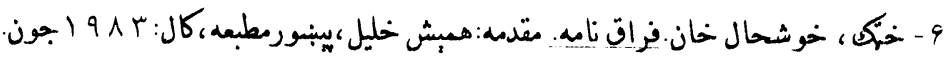

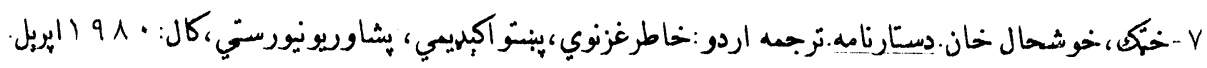

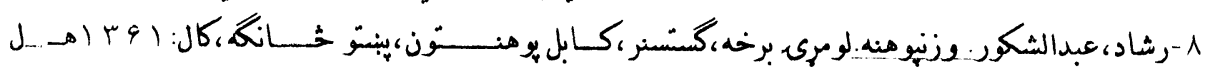

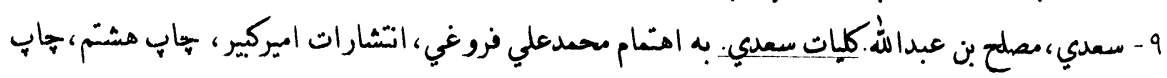
وصحافي، جابخانه سبرتهران، 9 9 ب 1. 


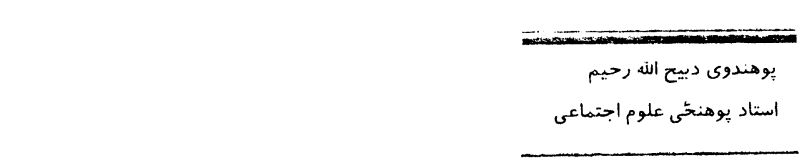

\section{خصوصيات جوامع سنتى و صنغتى \\ ازديدكاه جامعه شناسيان}

خllo

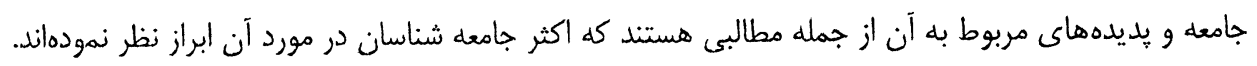

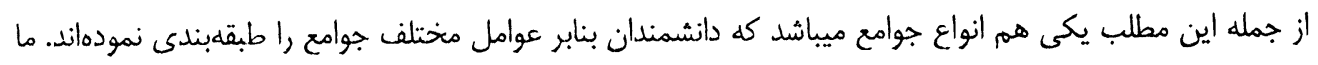

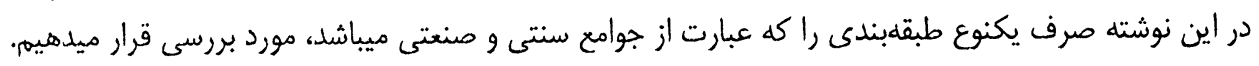

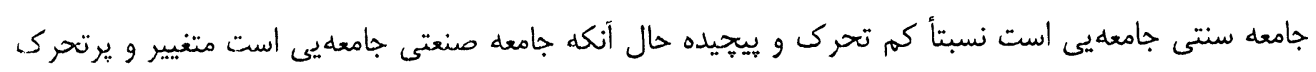

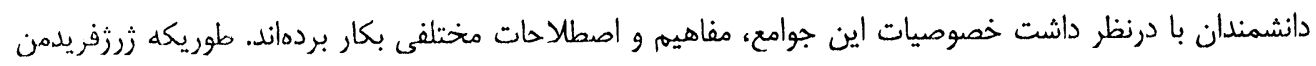

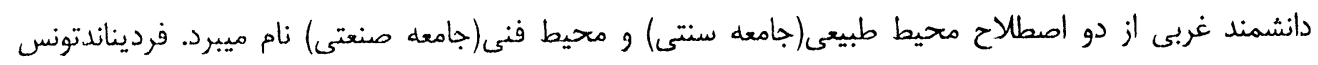

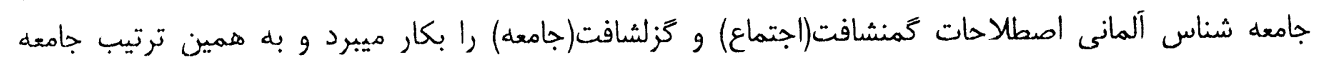

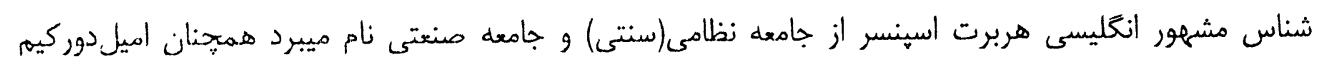

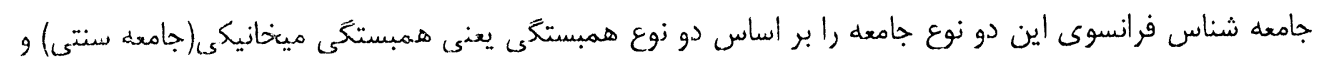

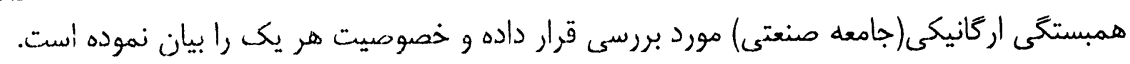

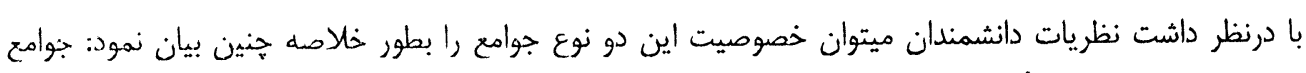

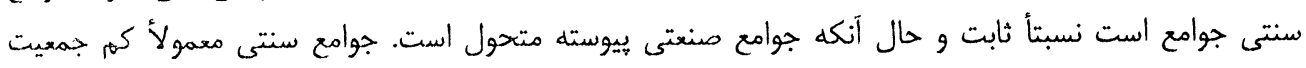

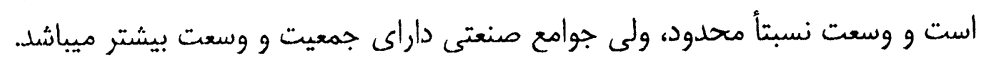

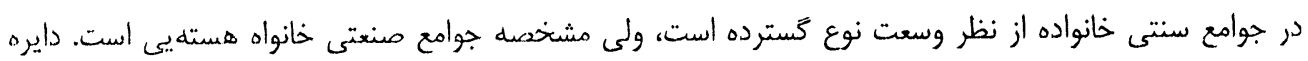

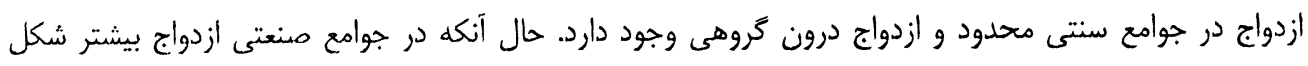

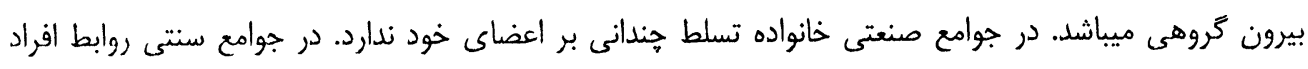

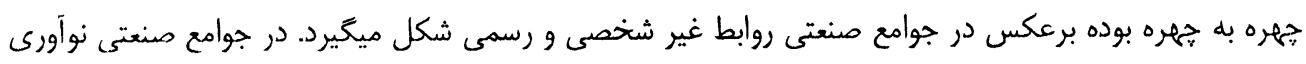

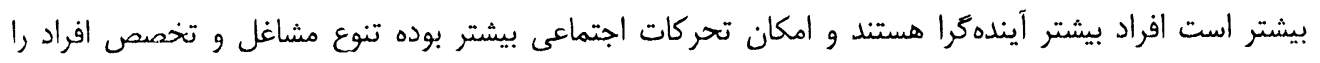

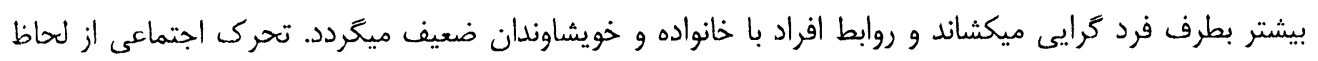

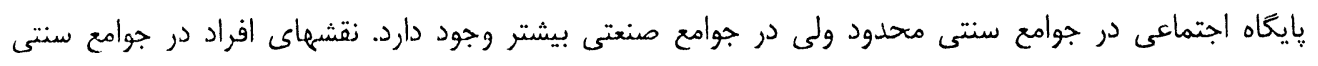

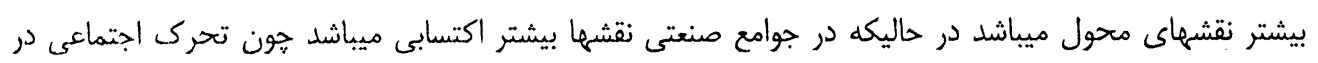


آنجا بيشتر است. خلاصه اينكه جوامع صنعتى بهمنظور رفاه عمومى سعى ميكند علاوه بر تامين نيازهاى

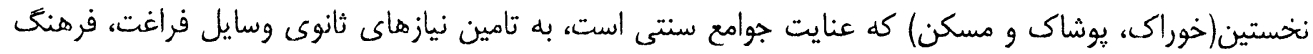
و غيره جوامع خود دست يابل.

: dastan

جامعه شناسان با توجه به تعاريفى كه از جامعه ارايه نمودهاند. همهنان با درنظر داشت خصوصيات جوامع

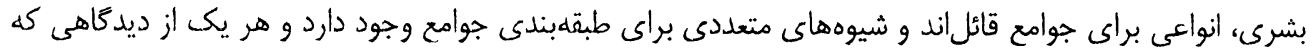

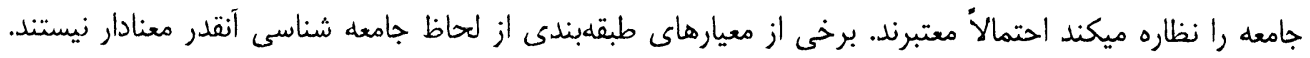

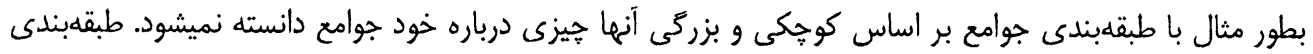

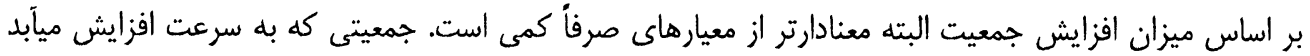

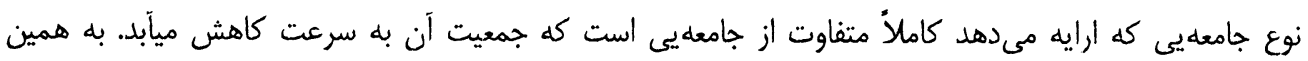

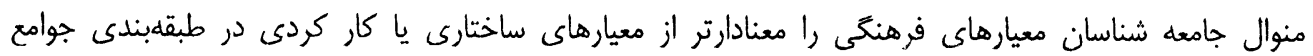

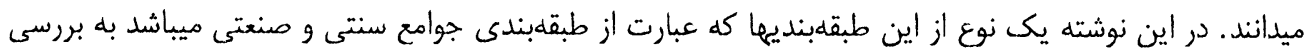

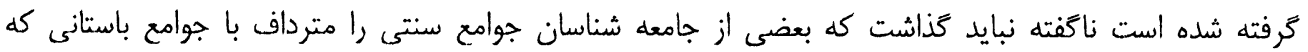

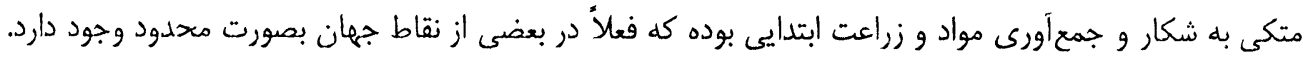

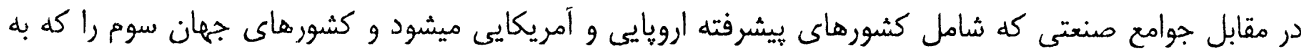

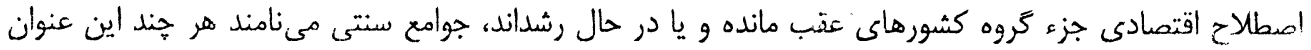

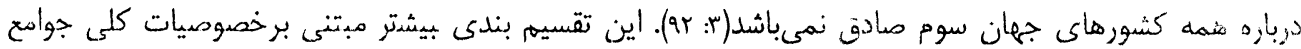
صورت تكرفته است.

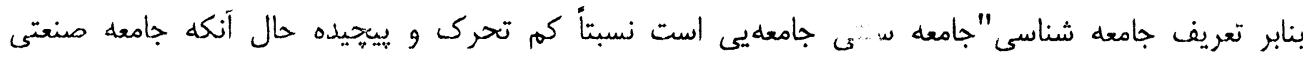

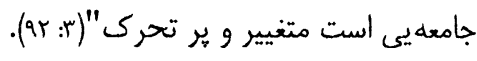

نظـريات جامعه شثناسان:

بنأ با درنظر داشت ارائه تعريف از هر دو نوع جوامع در قدم نخست نظريات جامعه شناسانى را به بررسى

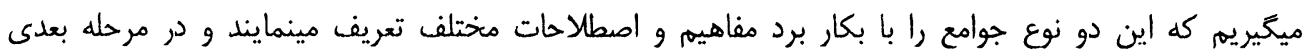

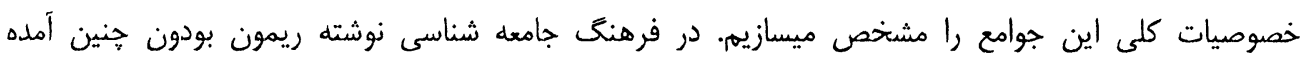

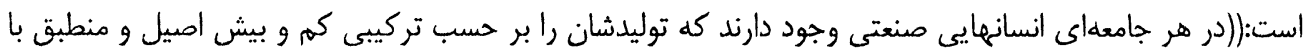

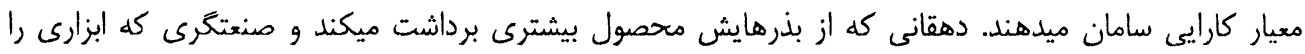

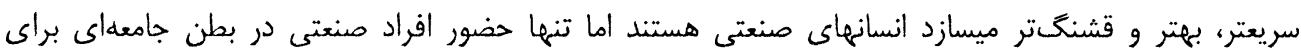

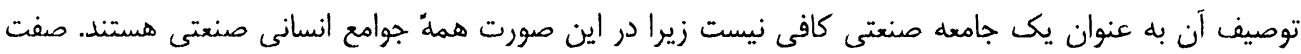




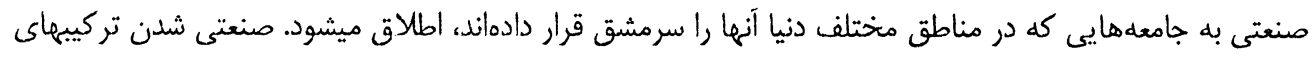

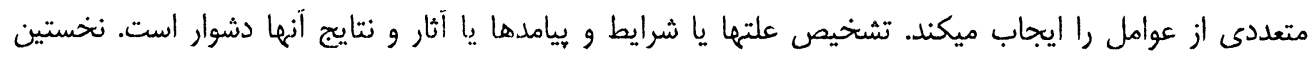

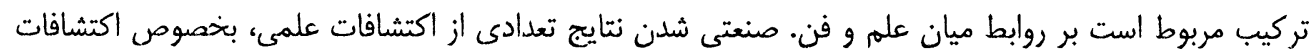
مربوط به استفاده از انرزى را به كار ميكيرد)(ان (238:1).

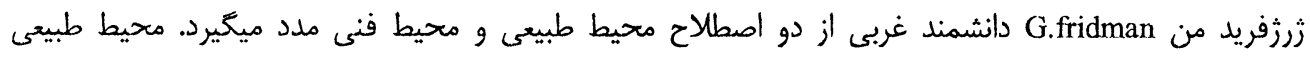

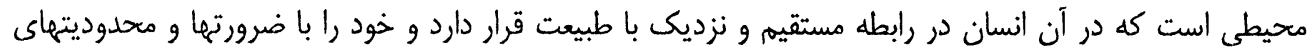

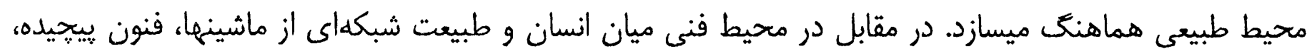

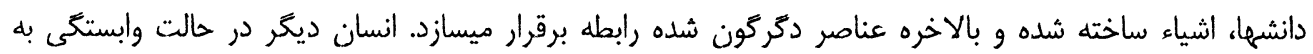

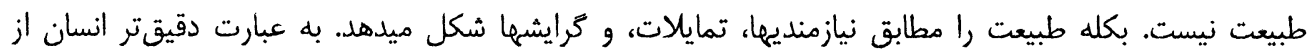

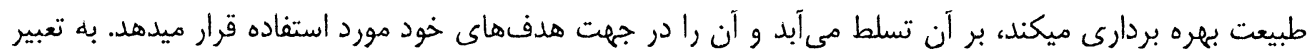

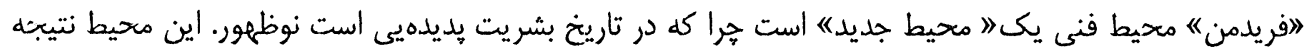

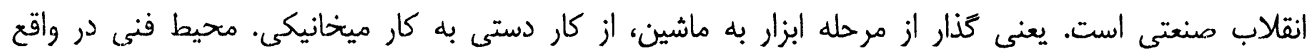
خصوصيت، جامعه نوين است(S: (TV).

فرديناند تونيس جامعه شناس ألمانى تز معروف كذار از اجتماع طبيعى(كمنشافت) را مطرح ميكند. تونيس صنعتى

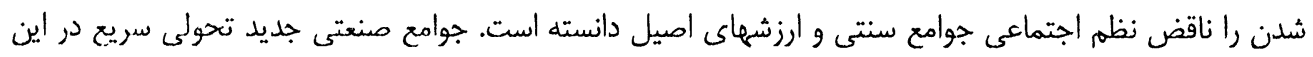

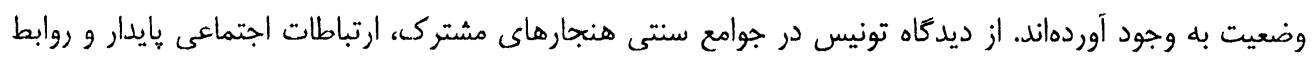

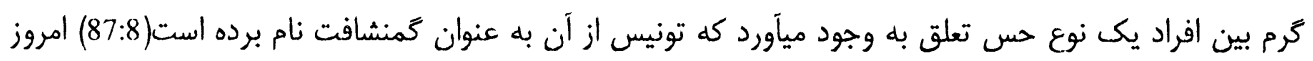

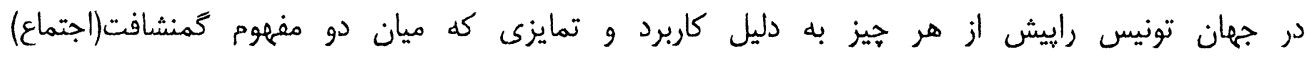

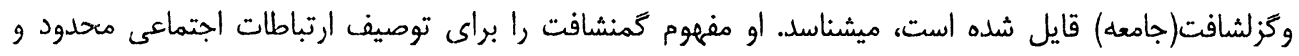

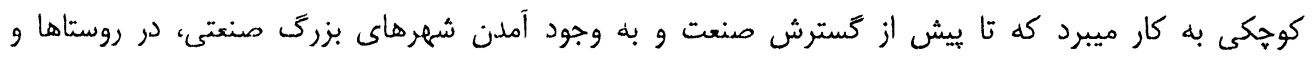

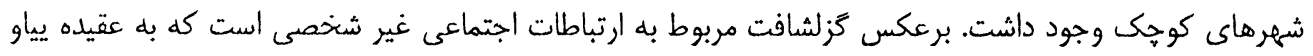

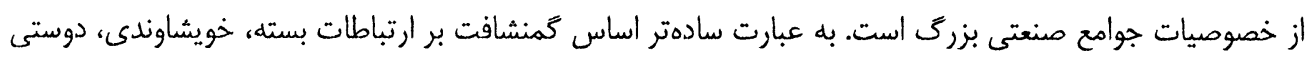

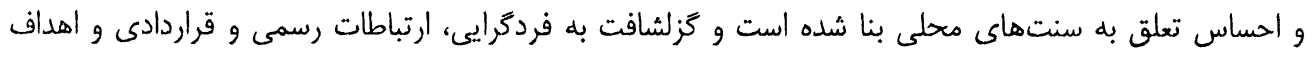
عقلانى(براى دستيابى به خواستهاى فردى) تاكيد ميكند.

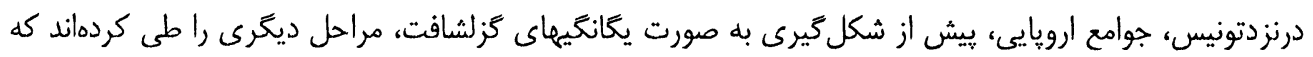

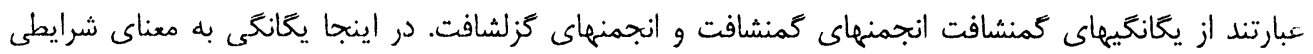

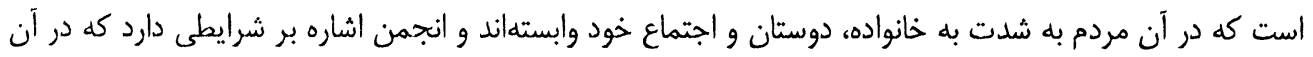

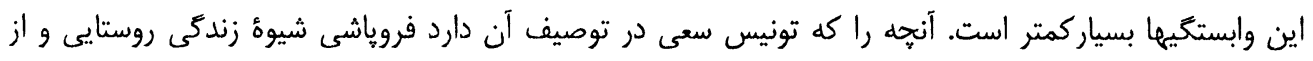

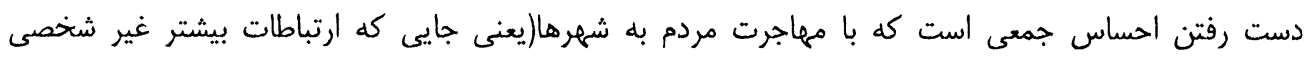

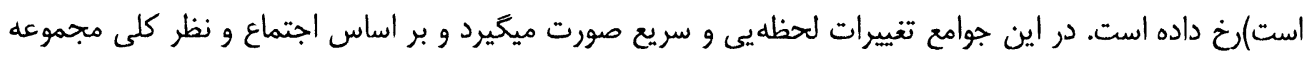




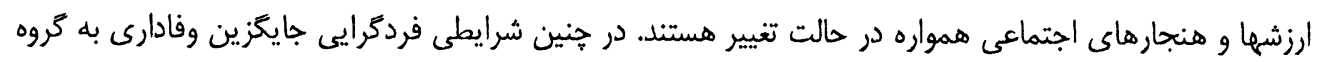

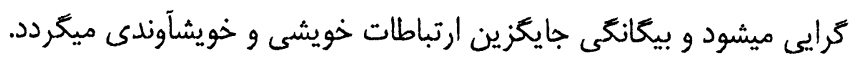

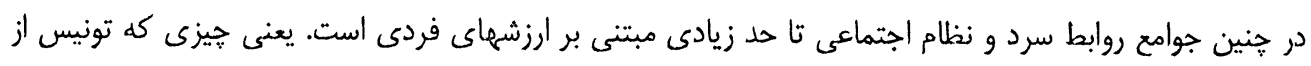
آن به عنوان "كزلشافته نام برده است.

هربرت اسبنسرفيلسوف و جامعه شناس مشهور انخليسى جوامع انسانى را به دو نوع تقسيم ميكند: جامعل نظامى كه براساس قدرت است.

جامعه صنعتى كه در آن متخصصان و صاحبان صنايع حكومت ميكنند(99:5).

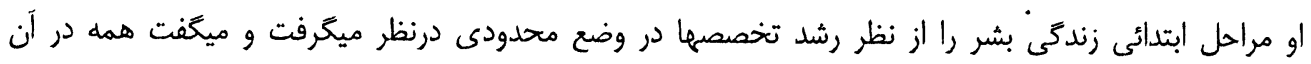

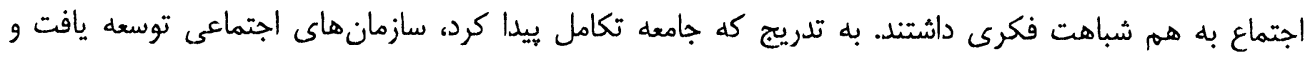

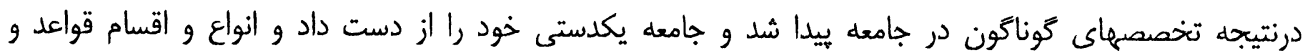
قوانين بر جامعه حاكم كرديد.

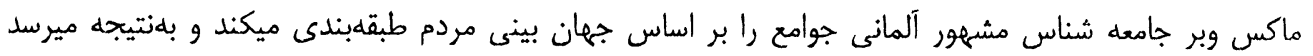

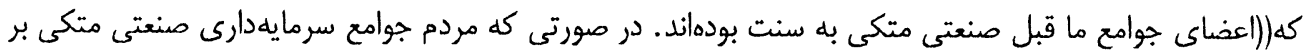

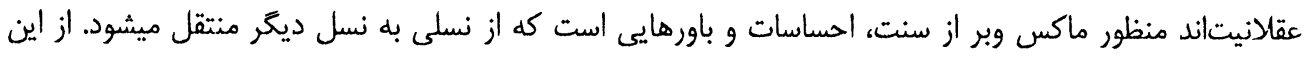

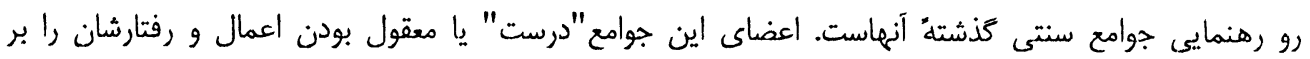

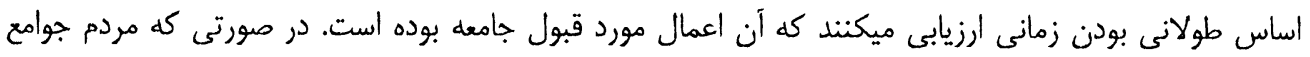

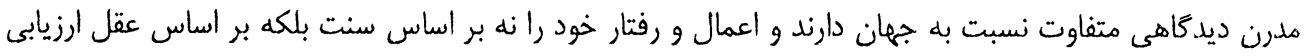

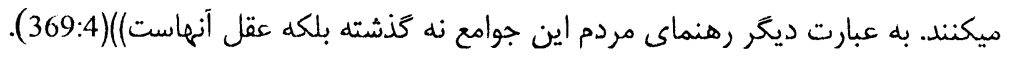

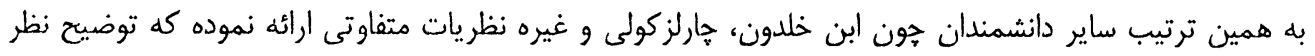

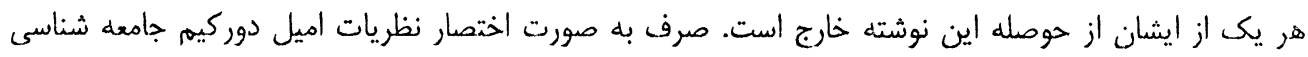
مشهور فرانسوى را توضيح مينمايهم.

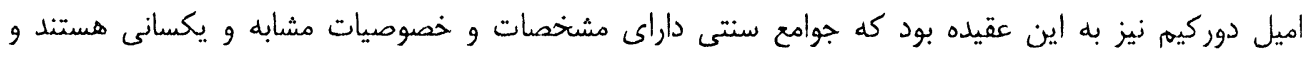

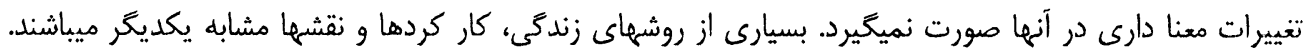

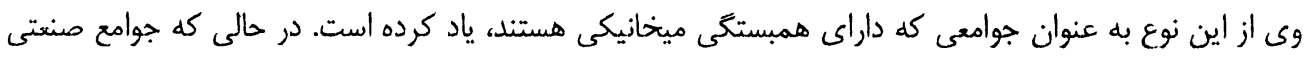

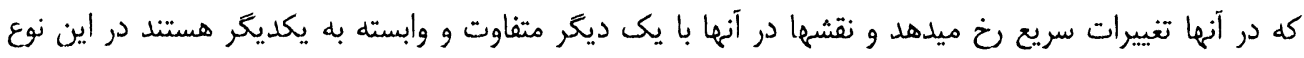

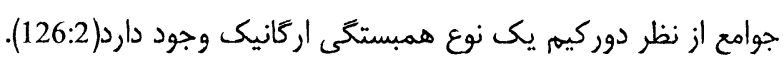
به عقيده ييدوركيم با رشد جمعيت، رقابت مردم بيشتر و كارها به تدريج تخصصى شده با تخصصى شدن كارها، 
مردم براى برآورده كردن نيازهاى خود بيشتر و بيشتر به ديكران وابسته شلند و ديگران نيز براى دريافت خدمات

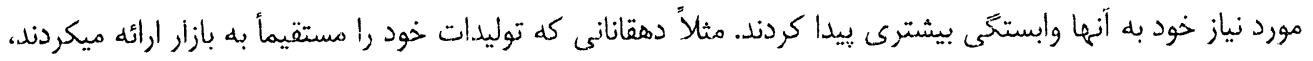

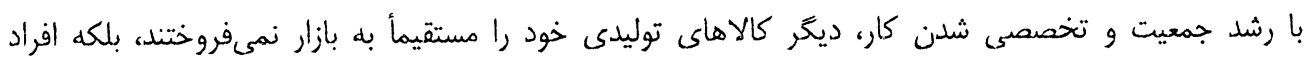

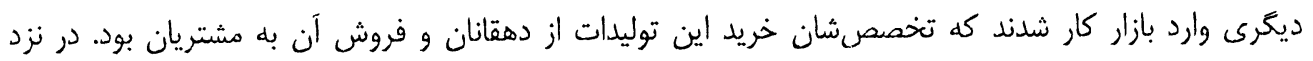

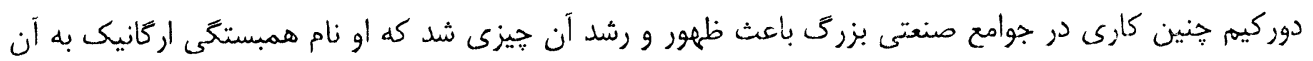

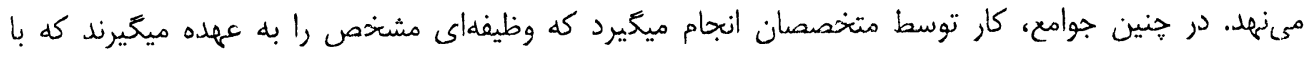

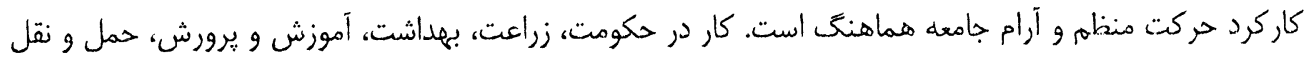

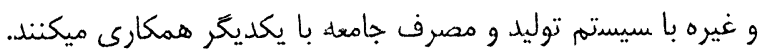

در جوامع نوع دوم همبستكى بين بخشهاتى مختلف جامعل اجتناب نايذير مينمايد. جوامع عصر حاضر مصداق بارزى

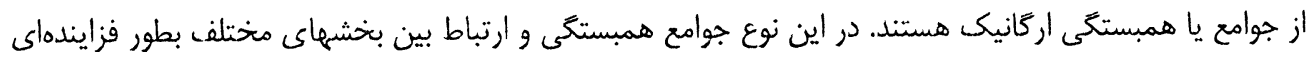

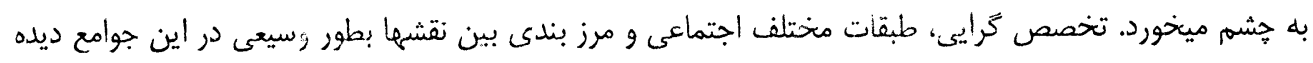

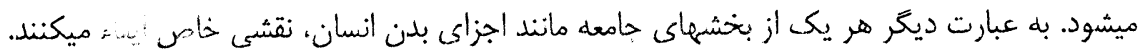
در جوامع صنعتى كه همبستخى ارثانيكى در آنها حكمفرهاست تقسيم كار وسيع و با ابعاد مختلف بطور اجتناب نايذير

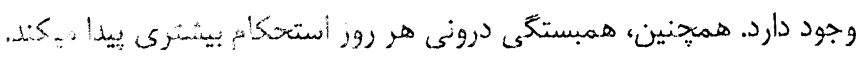

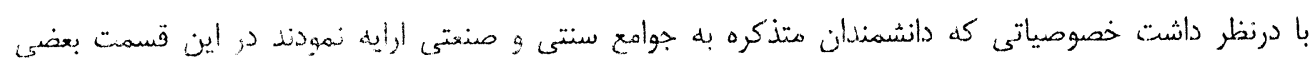
خصوصيات ديكر اين جوامع را جهت آثنايى بهتر بطور اختصار بيان هينمايهر.

$$
\text { خصوصيات اين دو بمو إمع: }
$$

جامعه سنتى جامعليى است نسبتاً ثابت و حال إنكه جامعه منعتى، زير تأثير تتييرات يبوسته متحول است.

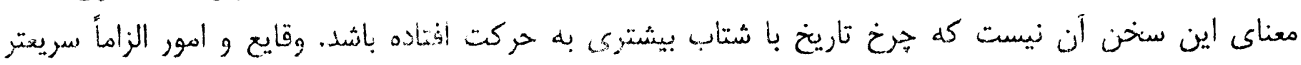

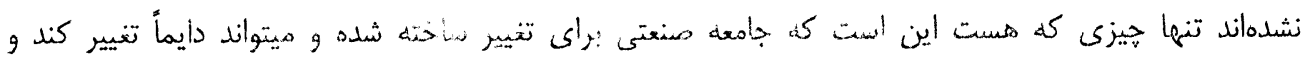

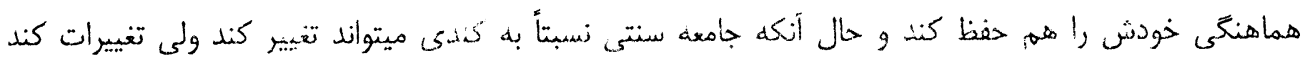
دستخوش تغييرات عميق ميگرددر(206:7).

معمولاً جامعه سنتى كمم جمعيت أست و وسعت نسبتاً محذودى دارد ولى جامعه صنغتى، داراى وسعت بيشتر و

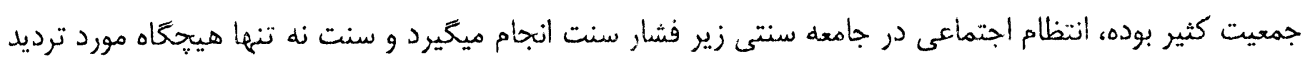

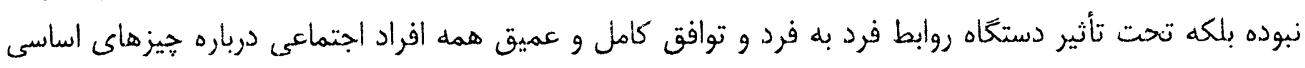

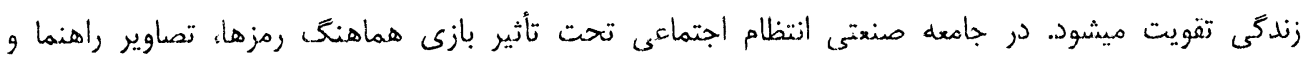

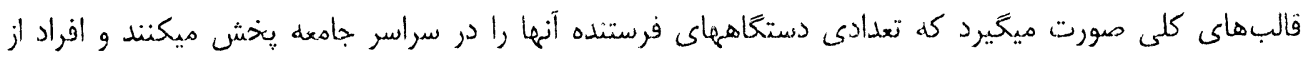


طريق دستخاههاى گيرنده راديو يا تلويزيون ميكيرند اما اين رمزها و تصاوير راهنما و قالبهاى كلى تا حدودى خود نيز محصول و انعكاس جامعهاند. در جامعه سنتى، نقشها، اساساً نقشهاى يِيجيده و محولاند و نقشهاى معدود اكتسابى تا حدود زيادى وابسته به

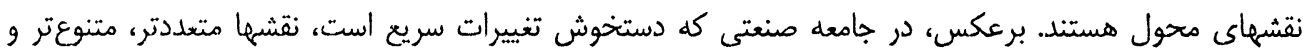

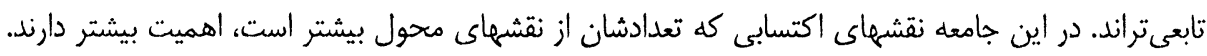
در جامعه سنتى همعان همه كس را ميشناسل، تعداد جمعيت نسبتأ محدود است و همه افراد در بين همر به دنيا

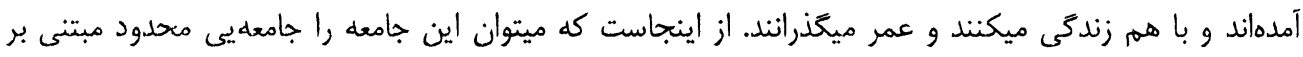

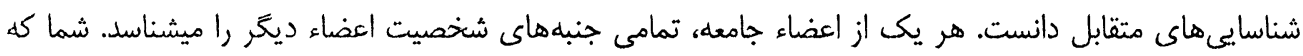

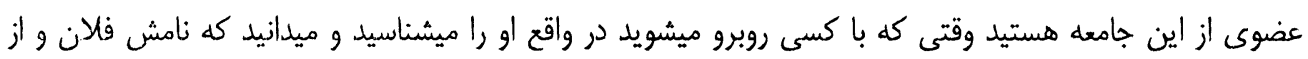

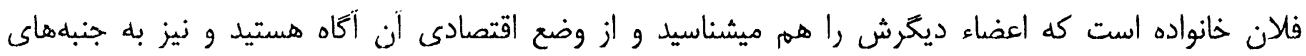
مختلف شخصيت افراد اين خانواده آكاهى داريد.

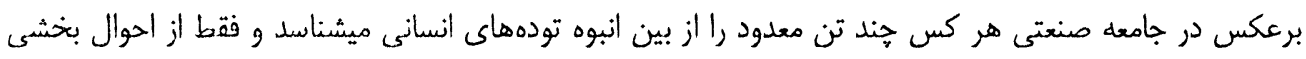

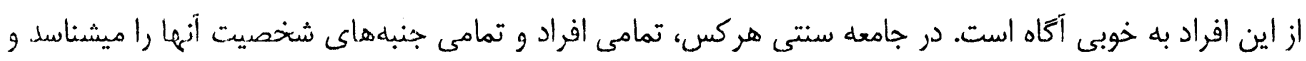

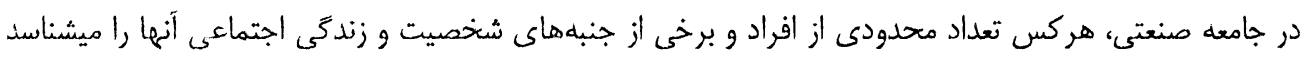

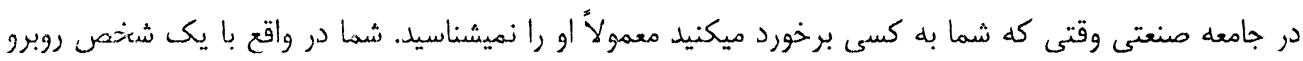

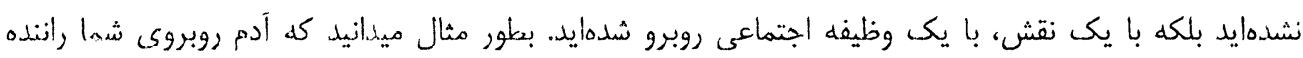
خياط و... است.

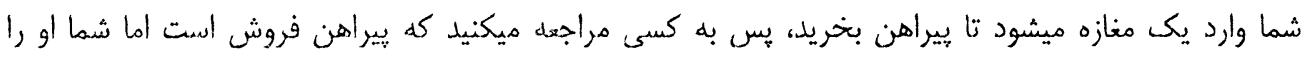

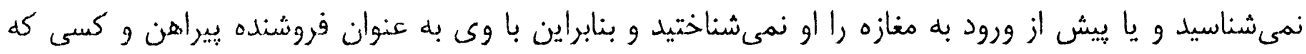

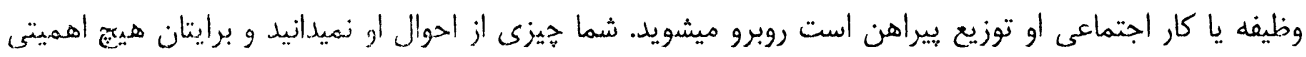

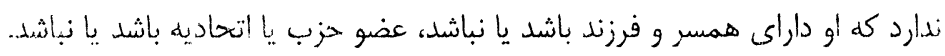

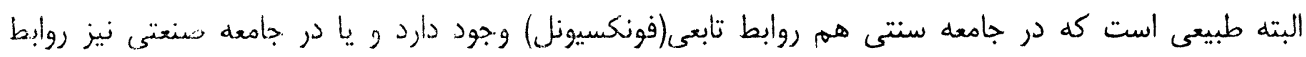

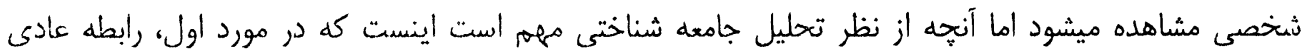

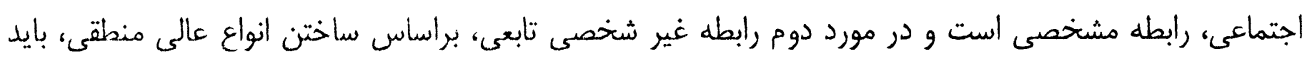

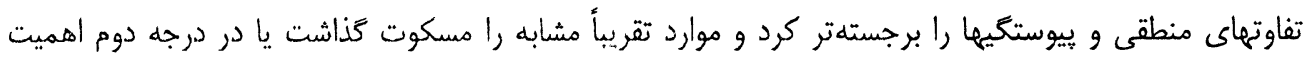
قرارداد(211:7).

در جامعه سنتى، از آنجا كه شخص همه كس را با تمامى جنبههاى شخصيت آنها ميشناسد نيازى به بيدا كردن

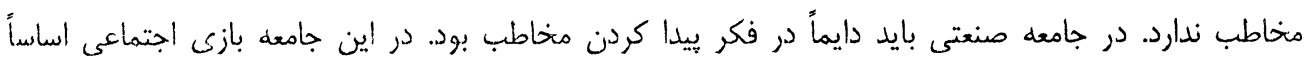

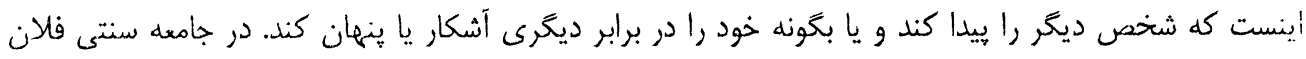


كس فلان خانواده است و بايد رفتار و زندگى خود را متناسب با تصويرى كه ديخران از او دارند، بنمايد و همه عمر

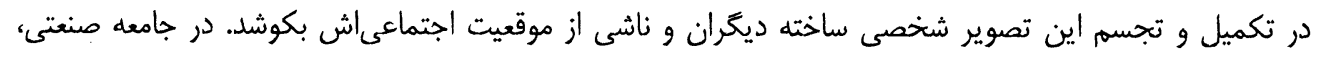

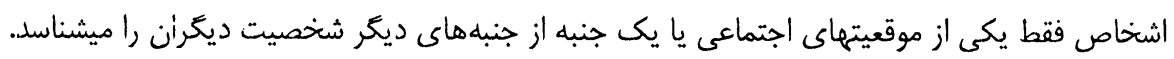

شاگرد معلمش را به عنوان معلم ميشناسد و معلم ميتواند برخى ديخر إز جنبهایى شخصيت و زندگى اجتماعى

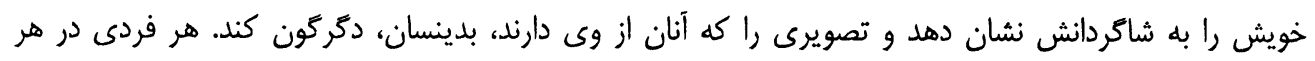

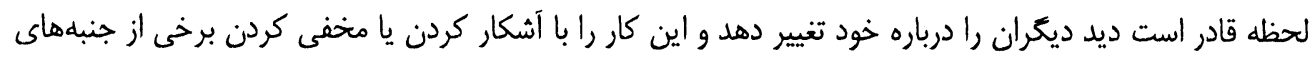

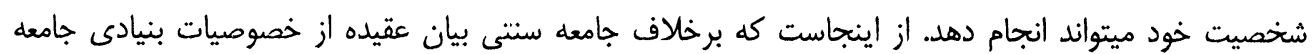

صنعتى به شمار ميرود.

در تعريف عقيده كفته ميشود كه عقيده واكنشى است در برابر وضعيتى تازه و بر اساس حالات نسبتاً ثابت (213:7)

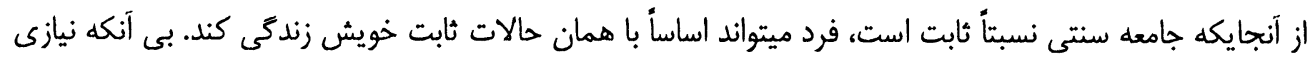

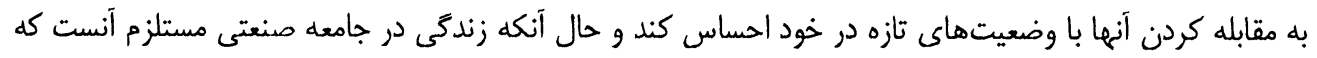

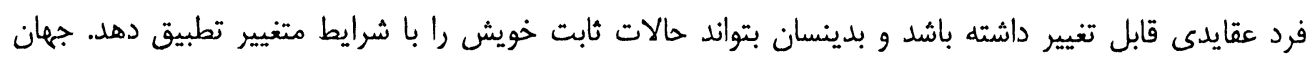

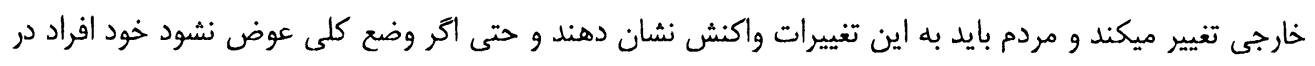

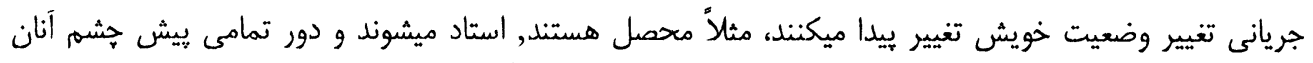

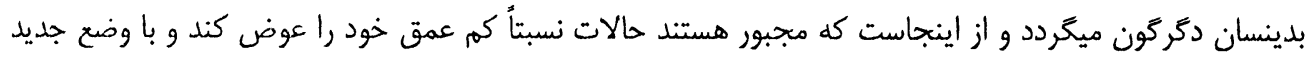
آشنا شوند و عقايد جديدى بيذيرند.

جامعه سنتى سعى در حفظ مجموعهها و بقايا دارد. در اين جامعه نوآورى مفهومى ندارد. معمولاً فرد از هنكام تولد تا

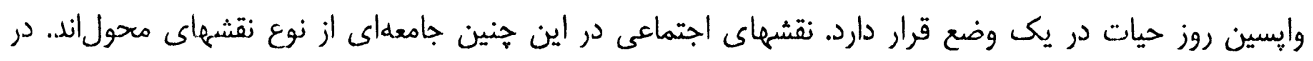

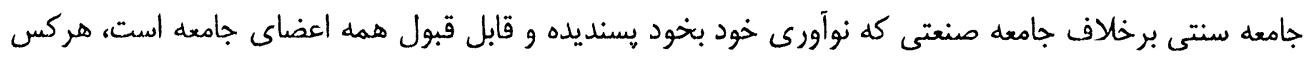

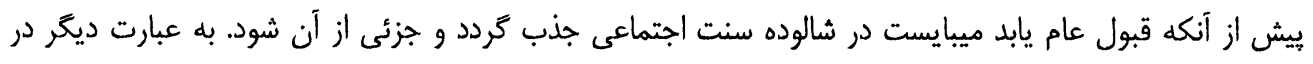

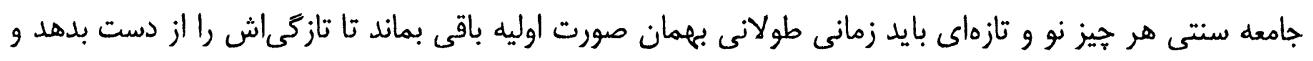
كهنه شود تا مورد قبول اعضاء جامعه واقع كردد.

در جامعه سنتى خانواده از نظر وسعت خانواده كسترده بوده ولى مشخصه جوامع صنعتى خانواده هستهيى و يا زن

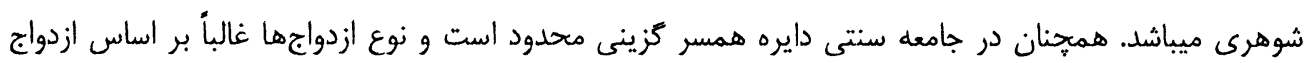

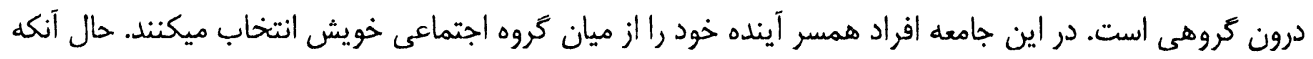

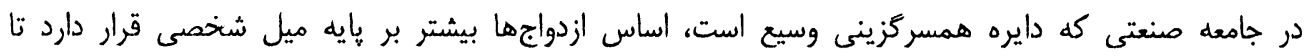

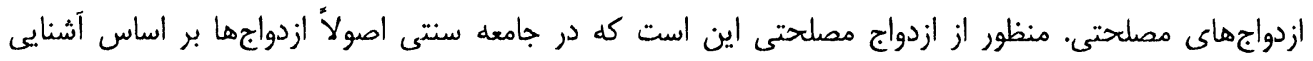

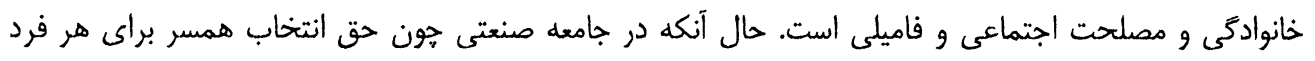


محترم شمرده ميشود و هر كسى ميتواند همسر دلخواه خود را در هر كجا كه باشد بيابد بيشتر تمايل و خواست فرد

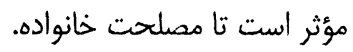

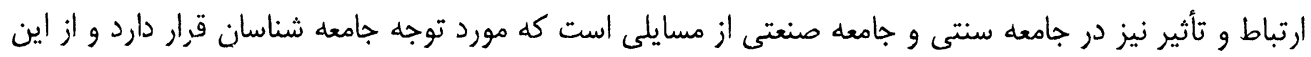

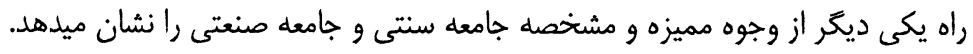

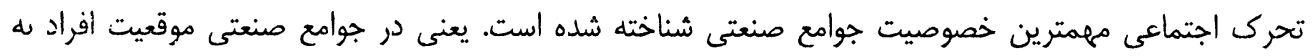

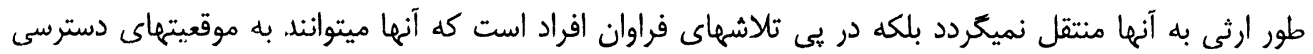

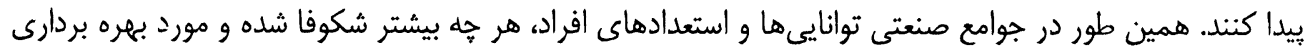

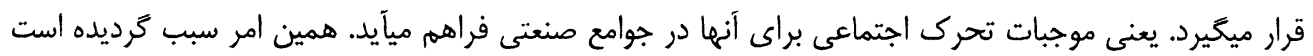

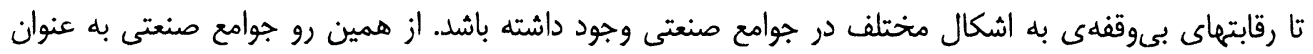

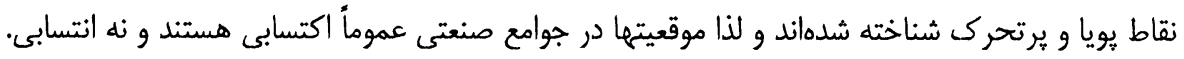

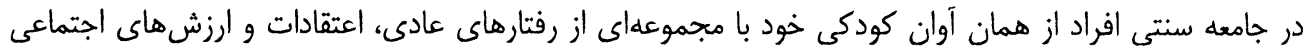

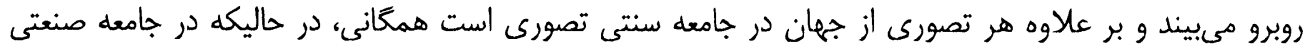

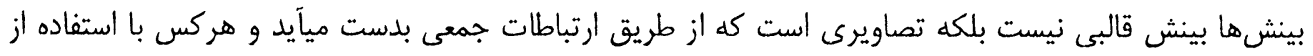
اين وسائل راه خود را در جامعه مشخصى ميسازد و احتياجى به حفظ مجموعههاى سنتى ندارد.

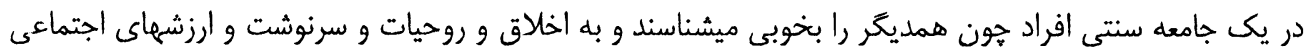

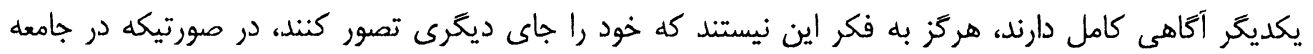

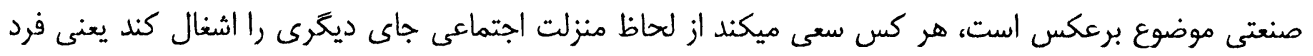

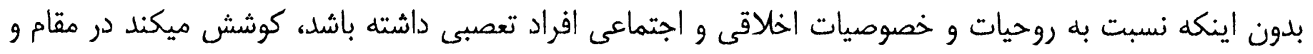

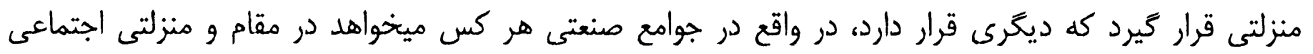

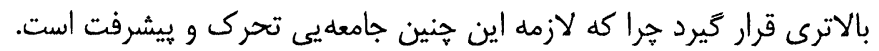

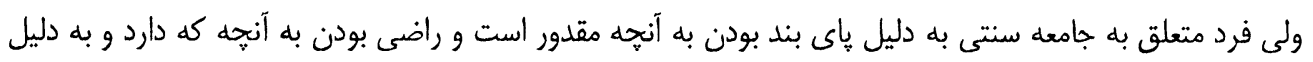

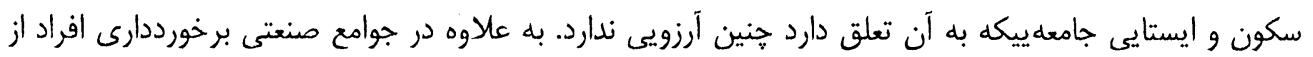

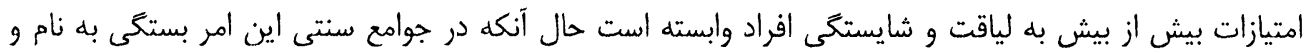

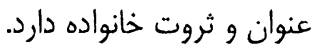

جوامع سنتى و صنعتى از لحاظ روابط اجتماعى نيز با يكديكر تفاوت دارند. در جوامع سنتى كنترول اجتماعى شده

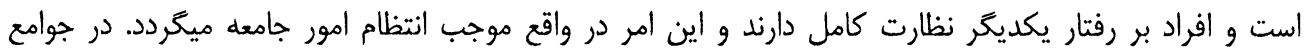

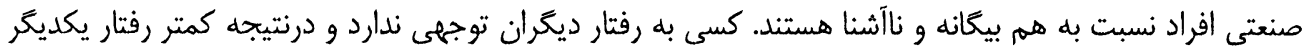

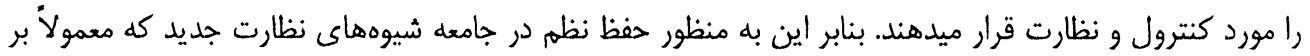

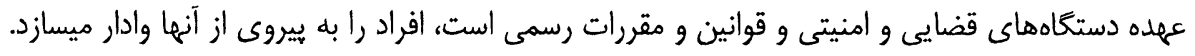


در جامعه صنعتى خانواده تسلط هندانى بر اعضاى خود ندارد. خويشآوندان به ندرت با يكديكر زناشوئى ميكنند و به به يه

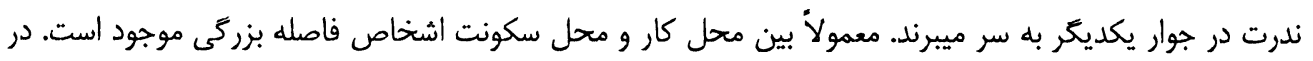

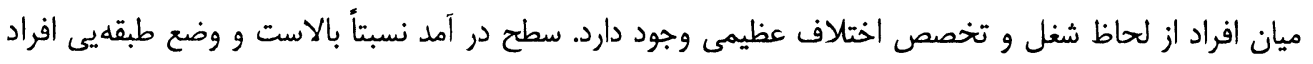

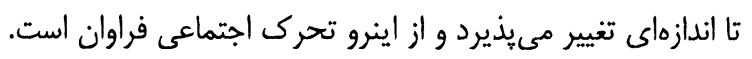

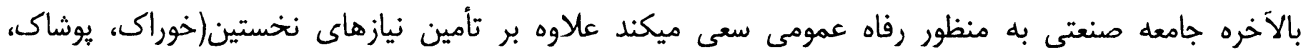

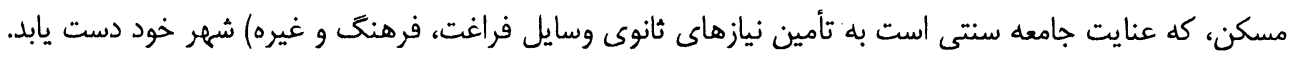

$$
\text { نتيجه كيسى: }
$$

جوامع صنعتى كه يكى از مشخصات انقلاب صنعتى به شمار ميرود از جهات مختلف اجتمات إنماعى، اقتصادى،

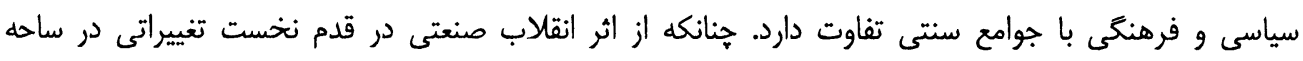

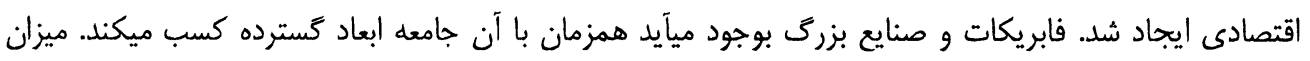

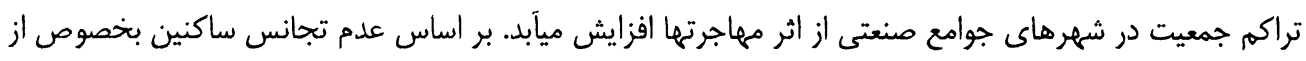

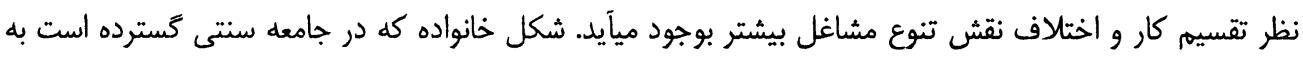

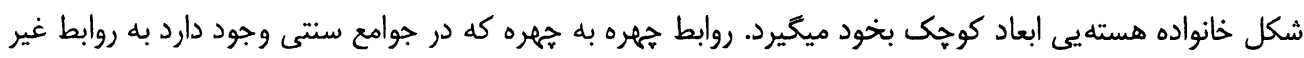

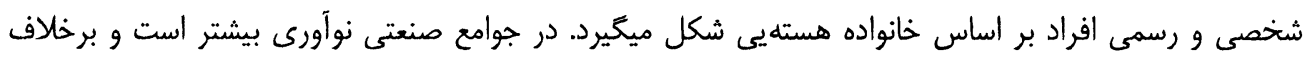

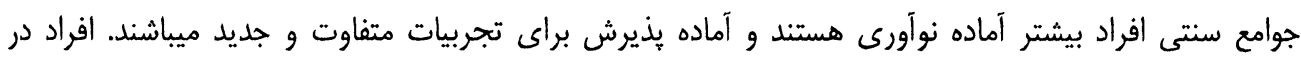

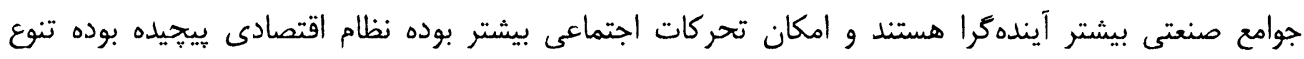

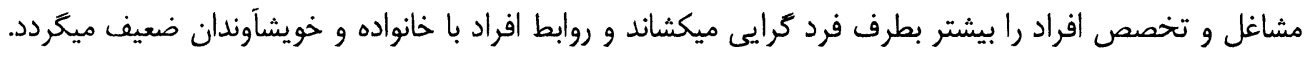

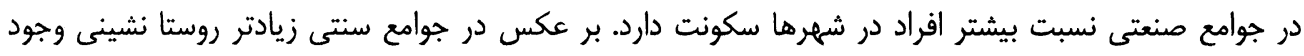

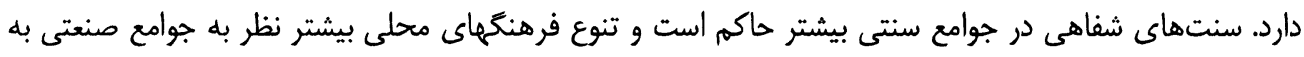
مشاهده ميرسد. 


\section{فنس مناع و مأخذ:}

ا. بودون، ريمون و بوريكو. هشזا. فرهنگ انتقادى جامعه شناسي ترجمه. عبدالحسين نيك گمر تهران: شركت

$$
\text { سهامى انتشار. }
$$

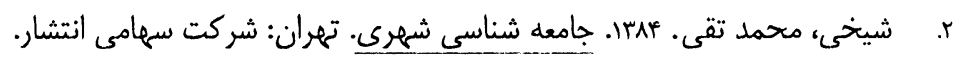
r. طبيبى، حشمت الله. ده广ا. مبادي و اصول جامعه شناسي. تهران: هابخانه اسلاميه.

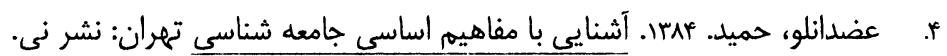
هـ محسنى، منوجهر. . .دا. جامعه شناسى عمومى. تهران: انتشارات طهورى.

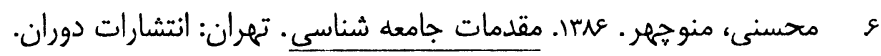
V. مندراس، هانرى.

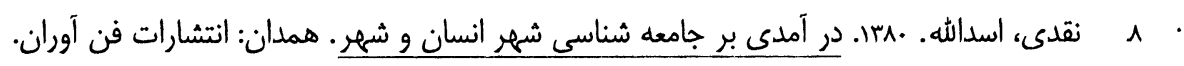




\section{تجليل، ارزيابى واستعمال

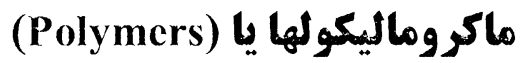

مقد مله:

يولى ميرها و يا ماكروماليكولها از ماليكولهاى كوجى كيمياوى حاصل ميخردد كه اين ماليكولهاى كوجى

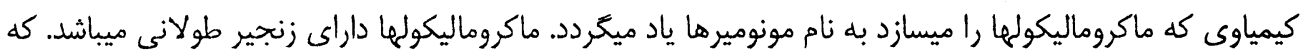
اين زنجيرها يا بصورت خطى، حلقوى، منشعب، اتصالات عرضى، شانه مانند، ستاره مانند و غيره يافت ميشودا(ه: + ..

ماكروماليكولها از جندين ماليكول كوجى كيمياوى حاصل ميگردد. كه طول زنجير ماكروماليكولها مربوط به تعداد

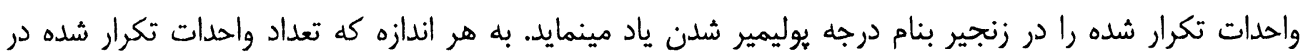

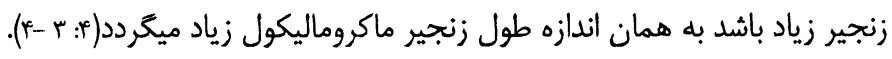

ماكروماليكولها داراى خواص و مشخصات جداكانه نظربه ماليكولهاى كوجك ميباشد. ماكروماليكولها داراى وزن

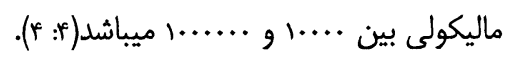

در ين تحقيق ماكروماليكولها مورد تحليل و ارزيابى قرار گرفته است. هدف اين مقاله علمى اينست تا

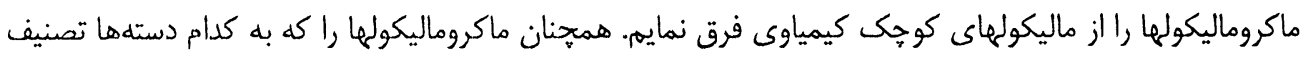

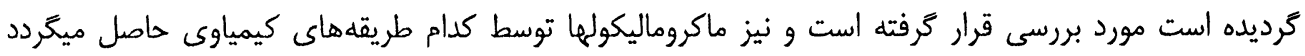

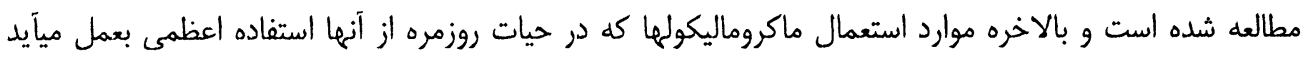
نيز مورد تحليل و ارزيابى قرارگرفته است.

ماكروماليكونها:

ماكروماليكولها عبارت از ماليكولهاى بزرى و مغلق ميباشد كه اين ماكروماليكولها از مركبات كوجه كيمياوى

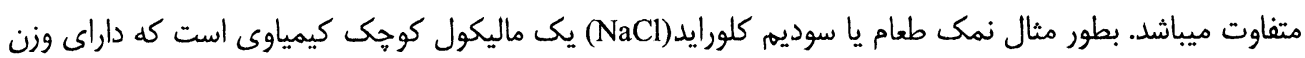

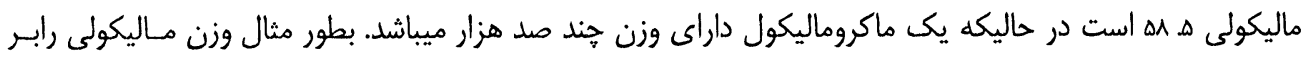

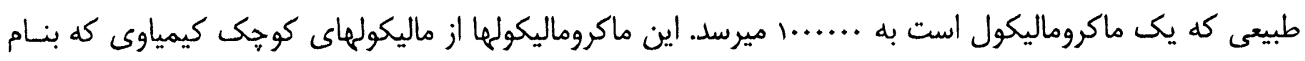

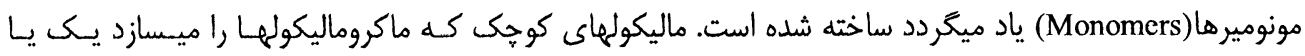
جندين مركبات كوجى كيمياوى ميباشد بطورمثال 


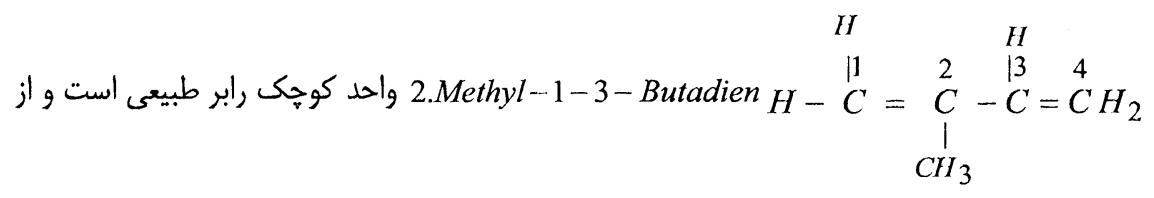

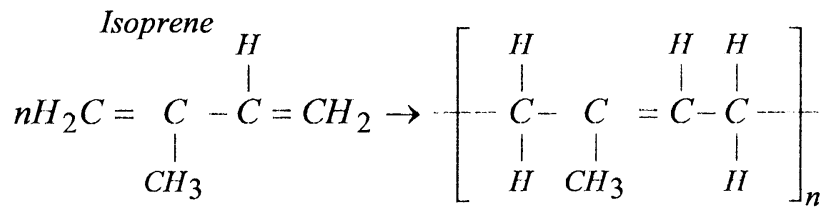

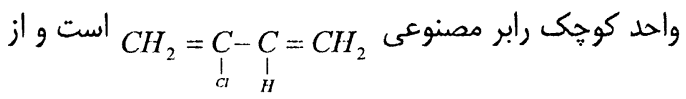

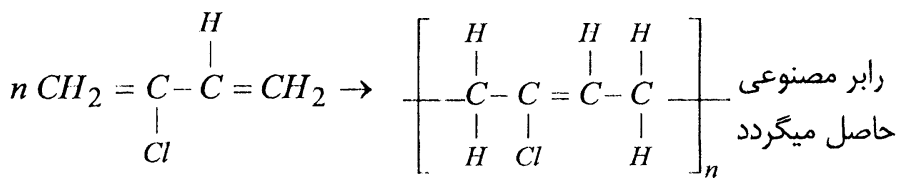

Chloroprene

Neoprene rubber

همجنان از مونوميرى وينايل كلورايد $\mathrm{CH}_{2}=\mathrm{CHCl}$ ماكروماليكول كه بنام بزرى كيمياوى قسمى صورت ميكيرد كه مونومير وينايل كلورايد كه واحد تكرارى است .... دفعه تركيب ميكردد

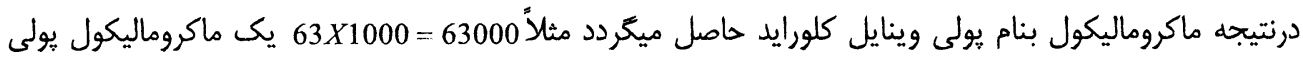

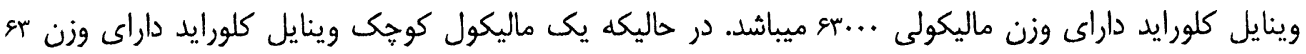

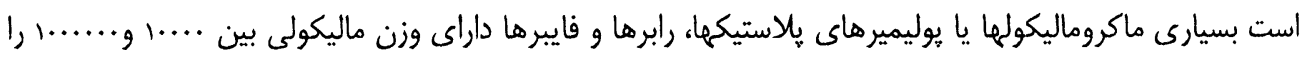
دارا است(

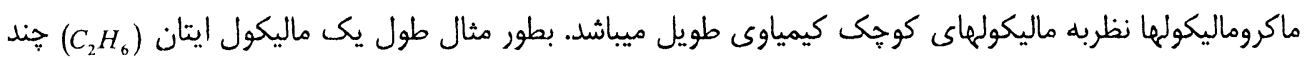

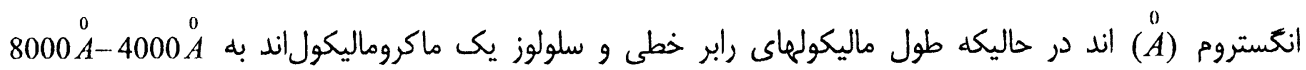

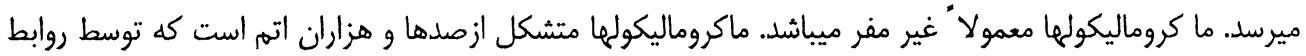


كيمياوى وصل كرديده است. ماكروماليكولها خواص متفاوت را با ماليكولهاى كوجى كيمياوى دارا است بطور مثال

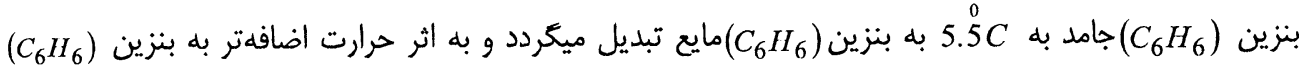

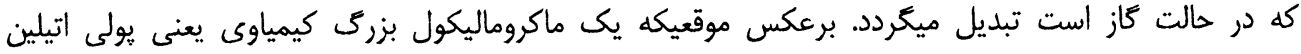

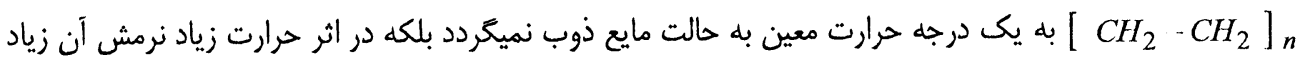

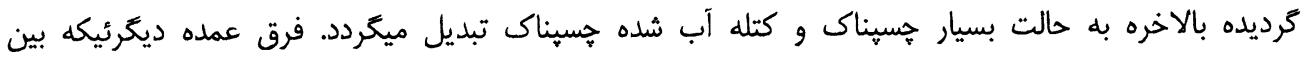

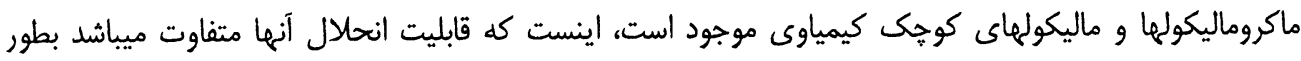

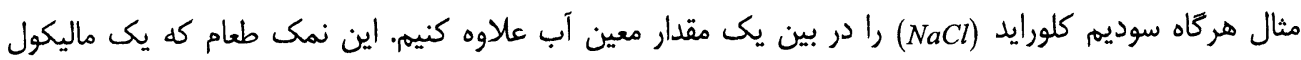

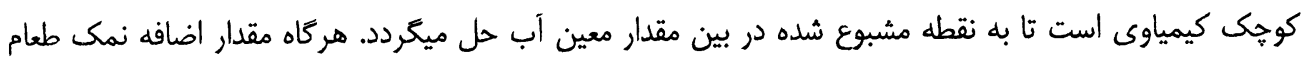

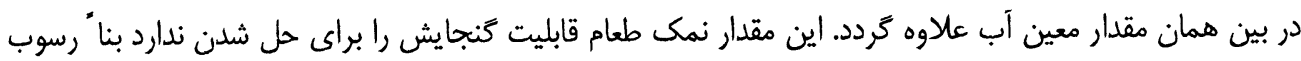

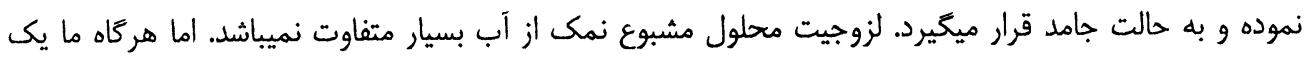
ماكروماليكول يعنى يولى وينايل الكهول

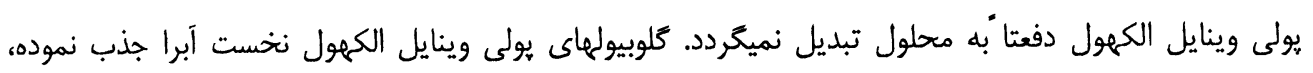

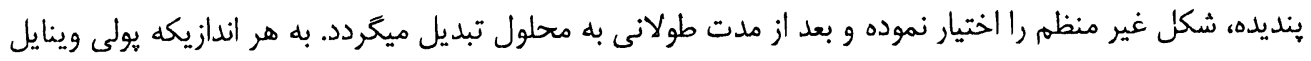

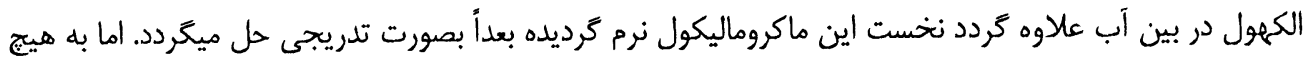

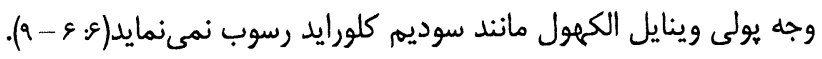

تصنيف ماكدوماليكولها:

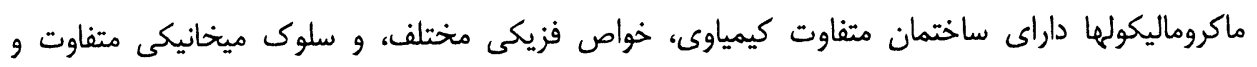

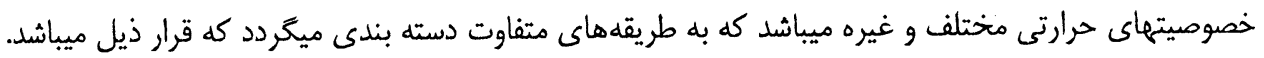

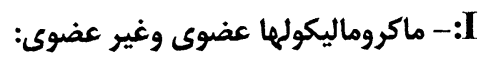

بعضى علما ماكروماليكولها را به دو دسته ذيل دسته بندى نموده است.

a

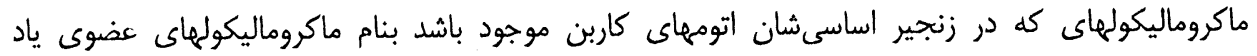

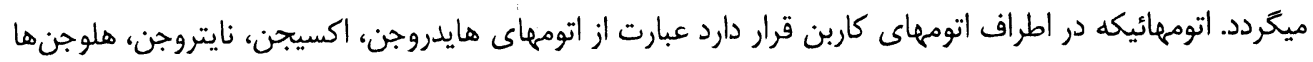
و و فاسفورساند.

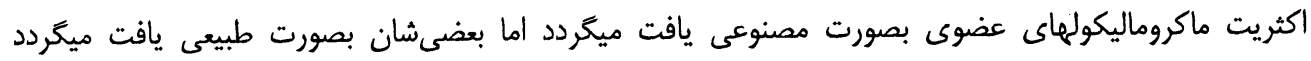

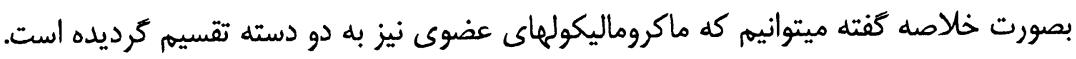




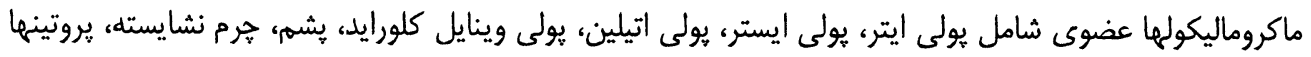

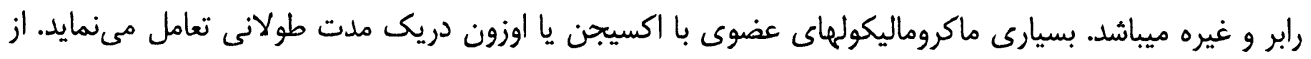

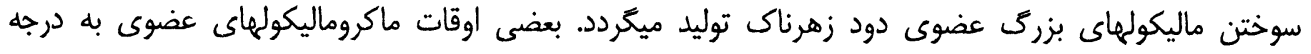

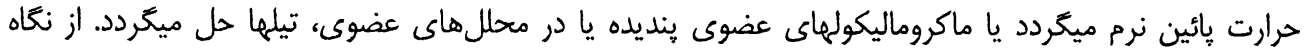

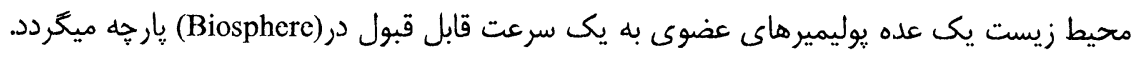

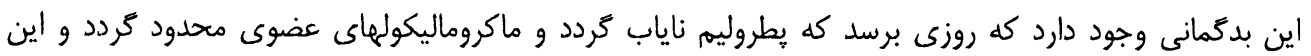

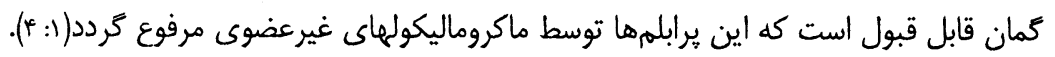

$$
\text { b : - - ماكروماليكولهاى غير عضوى: }
$$

ماكروماليكولهاى غيرعضوى داراى تعداد زياد عناصركرويهاى جهارم و ششمه جدول دورانى ميباشد روابط كه

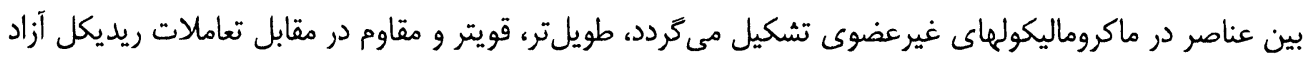

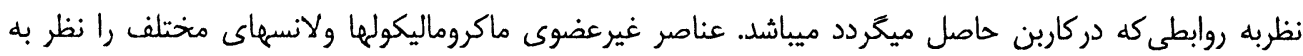

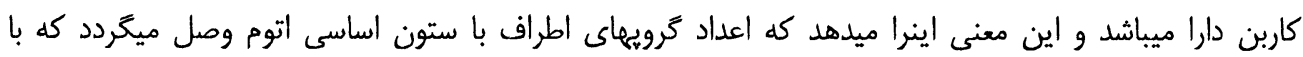

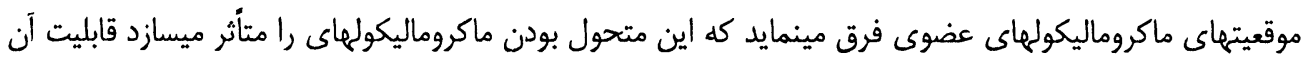

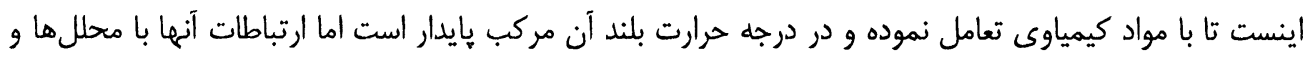

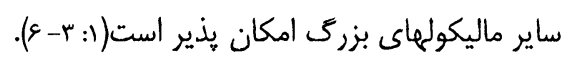

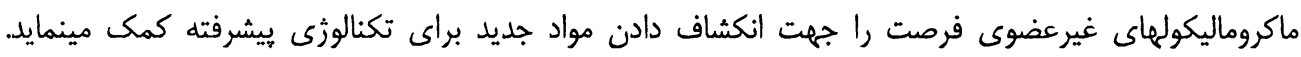
ماكروماليكولهاى غيرعضوى به دستههاى ذيل تصنيف ترديده است. ماكرومائيكولهاى غير عضوى اتومهاى متجانس:

اينها عبارت از ماكروماليكولهاى غيرعضوىاند كه در زنجير اساسى شان يكسان اتومها قرار دارد. اين ماليكولها در

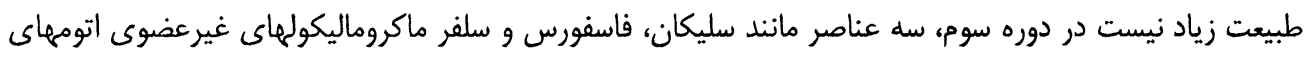
متجانس را ميسازد(1: ب- (ع).

$$
\text { ماكرومائيكولهاى غيـ عضوى اتومهاى غيس متجانس: }
$$

اينها عبارت از ماكروماليكولهاى غيرعضوىاند كه در زنجير اساسىشان بيشتر از يك عنصر موجود باشد(ا: r - ع). : - :II 


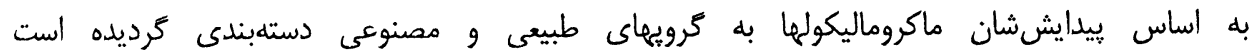

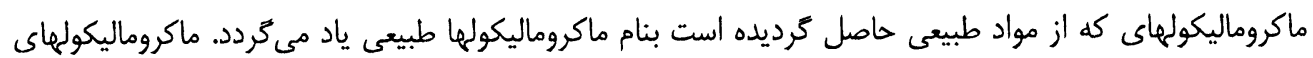

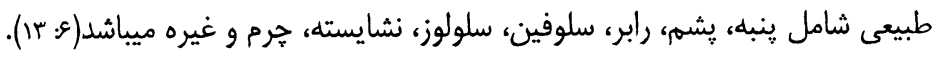
ماكروماليكولهاى طبيعى به سه دسته تقسيم كرديده است.

(a) يولى سكرايدها كه داراى فرمول عمومى

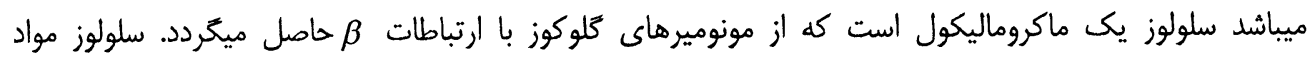

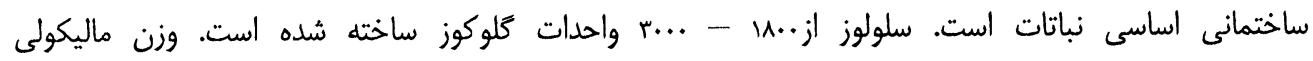
ماكروماليكولهاى سلولوز بين 500000u الى u

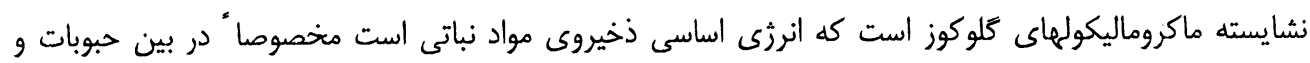

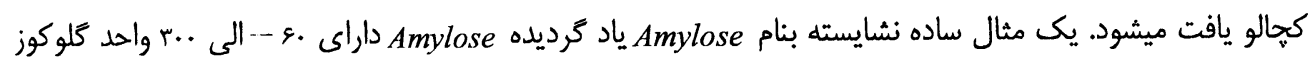

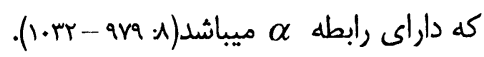
(b) يروتينها ماكروماليكولهاى امينو اسيدهاى الفا است. امينواسيد الفا داراى گروب كاربوكسيل و كروب امينو

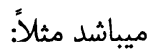

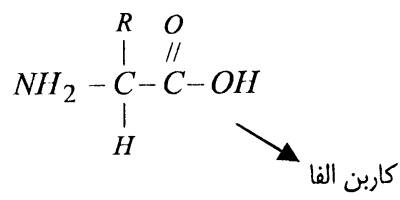

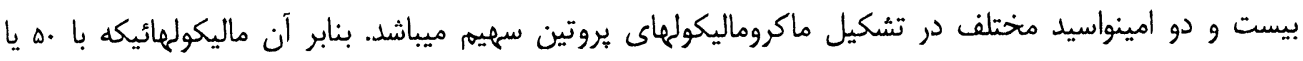

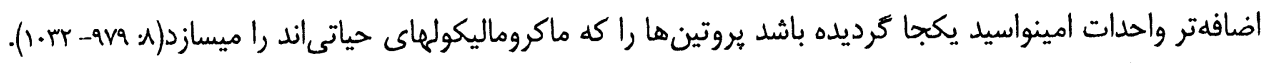

$$
\text { : (c) }
$$

نيوكليك اسيدها بحيث مراكز كنترول و معلومات حجرات ايفاى وظيفه مينمايد. دو نوع نيو كليك اسيدها وجود

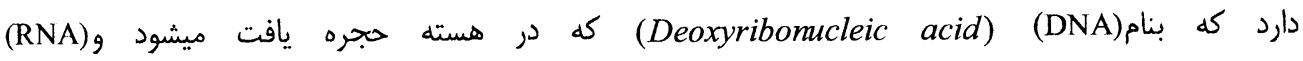

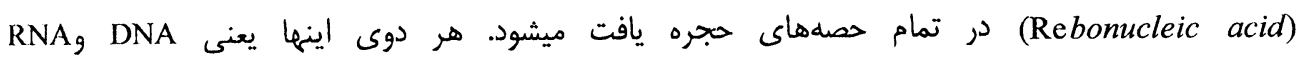

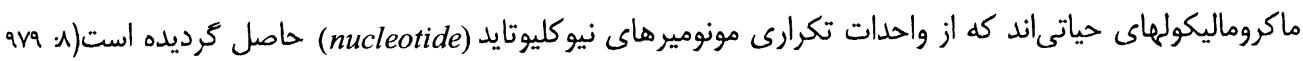


ب- ماكروماليكولهاى مصنوعى: ماكروماليكولهاى كه از مركباتيكه داراى وزن ماليكولى كوحيكاند حاصل

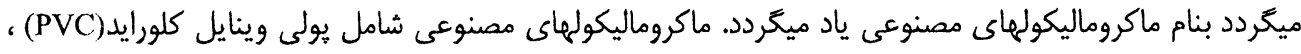

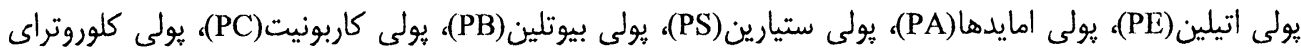

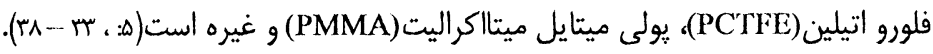
III ماكروماليكولها به اساس خواص ميخانيكى به دستههاى الاستوميرها(Elastomers) و پِاستوميرها (Plastomers)

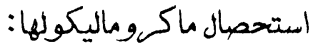

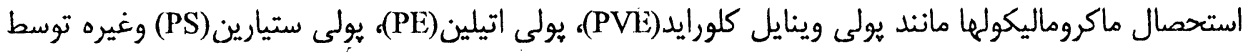
عمليه كه بنام يوليميرازيشن(Polymerisation) ياد ميشود حاصل ميخردد.

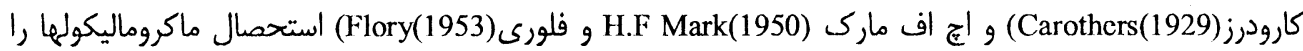
به دو دسته ذيل دستهبندى نمودند.

$$
\text { يوليمير شدن جمعى (r) يوليمير شدن تراكمى. }
$$

يوليمير شلن جمعى قسمى صورت ميخيرد كه سه مرحله را بايد سبرى نمايد و اين مراحل عبارتاند از:

$$
\text { (a) مركز فعال (b) نموى زنجير (c) ختم زنجير(ا: (a) (r) (r). }
$$

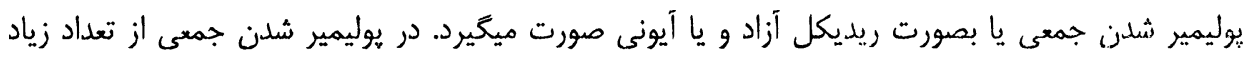

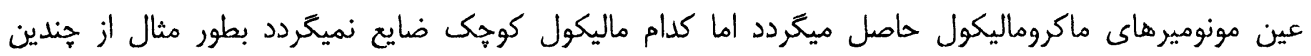

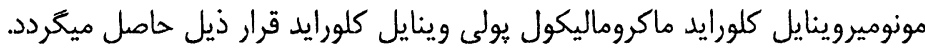

$$
n \mathrm{CH}_{2}=\mathrm{CICl} \rightarrow\left[\begin{array}{rrr} 
& \\
\mathrm{CH}_{2} & \mathrm{CH} \\
& \\
& \mathrm{Cl}
\end{array}\right]_{n}
$$

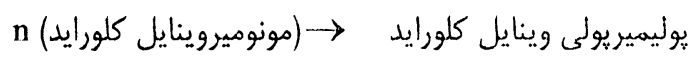

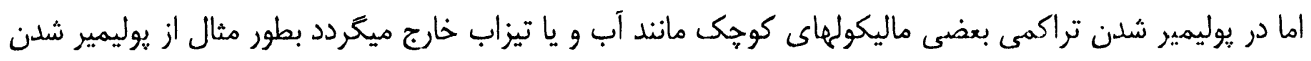

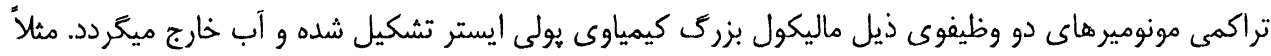
$\mathrm{XHO}-\mathrm{R}-\mathrm{OH}+\mathrm{XHOCO}-\mathrm{R}^{\prime}-\mathrm{COOH} \rightarrow \mathrm{HO}\left[-\mathrm{R}-\mathrm{OCO}-\mathrm{R}^{\prime}-\mathrm{COO}-\mathrm{I}_{X} \mathrm{H}+(2 \mathrm{X}-1) \mathrm{H}_{2} \mathrm{O}\right.$ (ro : * *) 
ماكروماليكولمها موارد استعمال فراوان را در صنعت، طبابت، زراعت لوازم خانه، نيازمنديهاى مردم و غيره دارا

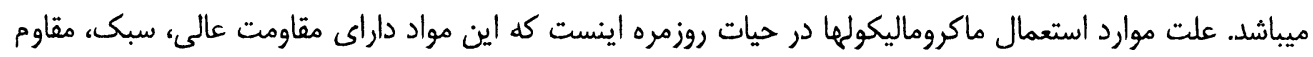

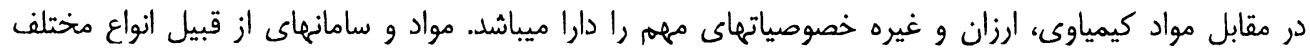

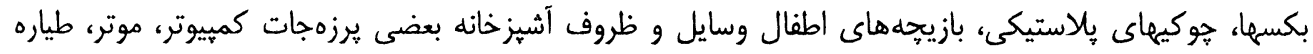

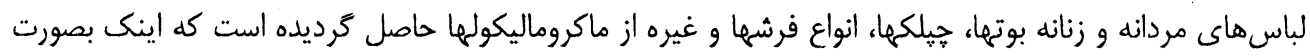

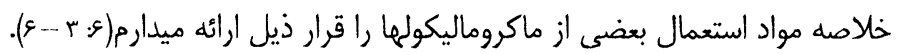

يولى ايتلين(PF): اين ماكروماليكول در توليد انواع لوازم، ظروف آشيزخانه، نلهاى آبيارى و نلهاى آبهاى خانكى، بازيجهها و ظروف يلاستيكى خانگى مورد استفاده قرار ميخيرد.

يولى يرويلين(PP): اين ماكروماليكول در يخهالما راديوها و تلويزيونها استفاده ميكردد و همجنان اين ماكروماليكول

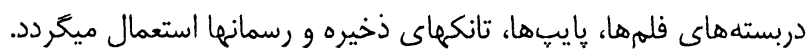

يولى ستيارين(PS): يك ماكروماليكول ديكر است كه در ظروف سريوشها، مرتبانها، بوتلها بازيجهها و ساير اقلام ضروريات منزل مورد استفاده قرار ميخيرد. يكارين

يولى ميتايل ميتااكراليت(PMMA): اين يوليمير در تختههاى اعلانات و در تعميرات بحيث اشياى تزين مورد

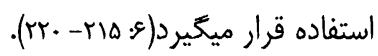

يولى وينايل الكهول (PVAL): ماكروماليكول يولى وينايل الكهول در سيستمهاى سسينرن و ايملشن، در فايبرهاى نساجى و غيره استعمال ميكردد.

يولى وينايل كلورايد(PVC): ماكروماليكول يولى وينايل كلورايد در يوشهاى سيتهاى موترها، فرشها بردههاى

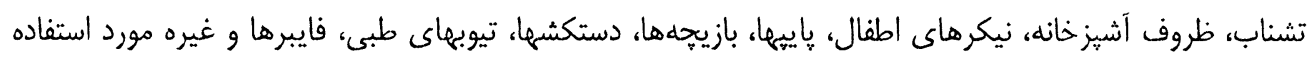
قرار ميغيرد.

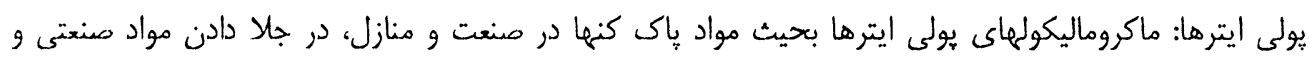

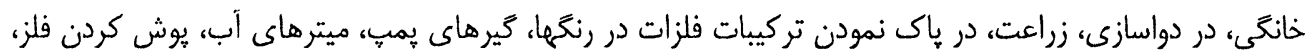

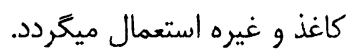

يولى ايسترها: ماكروماليكولهاى يولى ايسترها در سقفهاى خانه، لباسها، كشتيها، طيارهها، دكمها، بادى لاريها،

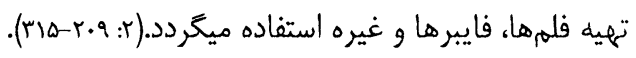




$$
\text { تنتيجد: }
$$

\section{References:}

1. Bhagi,A. K.,G.R.Chatwal.2001, A Textbook of Inorganic Polymers, First Edition. Himalaya Publishing House. New Delhi, India.,PP.3-6.

2. Bhatnagar, M.S,2008. A Textbook of Polymers Volume I, First Edition. S.Chand and Company LTD. New Delhi, India., PP.2-315.

3. Bhatnagar, M.S. , 2008. A Textbook of Polymers, Volyme II. First Edition, S.chand and Company LTD, New Delhi, India.,PP.186-191.

4. Billmeyer, Fred. W, JR, 2003. Textbook of Polymer science Third Edition. A wileyInterscience Publication, New york, PP.3-25.

5. Braun, D. , H. Cherdron.,M.Rehehn,H.Ritter and B.Viot. 2007. Polymer synthesis: Theory and Practice, Fundamentals, Methods, Experiments,

6. Gowariker, V.R., N.V. Viswanathan \& Jayadev Sreedhar.2008. Polymer science. New Age Internation al Publisher. India , PP.3-220.

Fourth Edition. Springer, Berlin., PP.4-38.

7. Hiemenz. Paul C,1984. Polymer chemistry, Marcel Dekker,INC., USA.,PP.1-20.

8. John.w.H.,R.H.Petrucci,1999. General Chemistry,Second Edition.Prentice Hall. NewJersey., PP.979-1032.

9. Muhammad,Z.I, 2006,Inorganic Chemistry,A1-HIJAZ Printers,Lahore,Pakistan., PP.679-680.

10. Vollhardt. K. Peter C., Neile.schore. 2003. Organic chemistry, Fourh Edition.W.H.Freeman and Company.,New york., PP.1147-1149. 


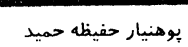

استاد بوهنجى فارمسى

\section{بررسى تاثيرات توكسيكولوزيك و}

\section{خذه مارها}

مقدمه:

انسانها از زمانههاى بسيار قديم با زهر يك تعداد حشرات و خزندهان آشنائى داشتند و از زهر مار براى آغشته

نمودن تيرهاى شان كار ميكرفتند(r).

حشرات زهرى از نكاه طبقهبندى در كلاسهاى مختلف از حشرات وجود دارند. بطور مثال مار، گُردم، يك تعداد از

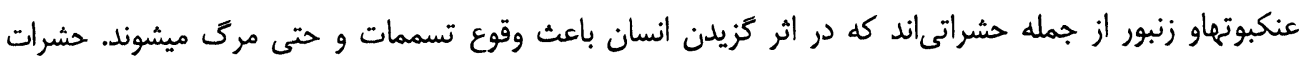

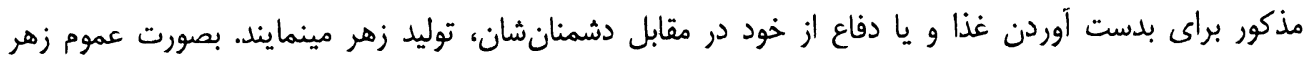

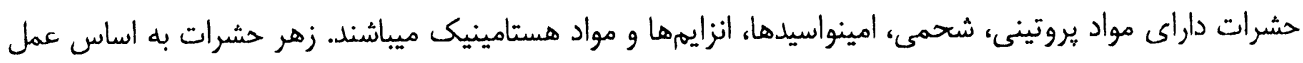

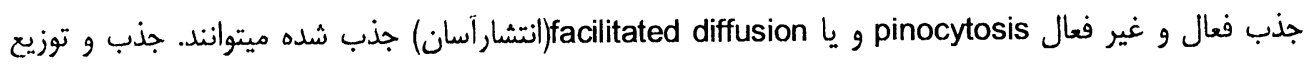
سموم حشرات نظر به اندازة ماليكول، جارج و انحلاليت آنها در مايعات بدن و جريان خون از هم فرق ميكردد. وخذه ماريكى از واقعات شايع در سراسر جهان بوده و تعداد قابل ملاحظه مسمومين در اثر وخذه مارها حيات

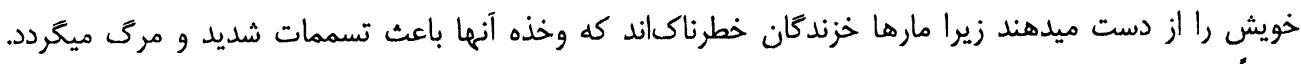

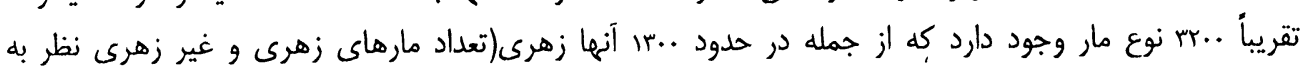

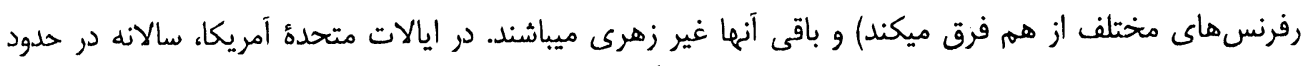

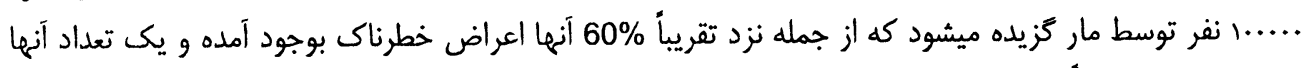

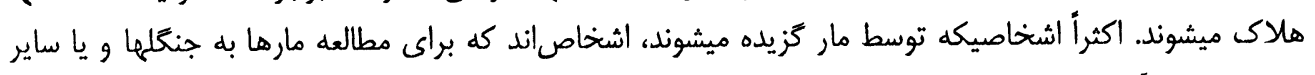

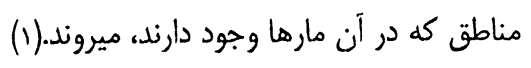

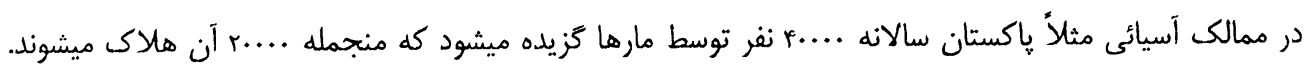

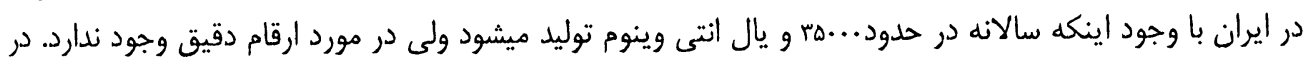

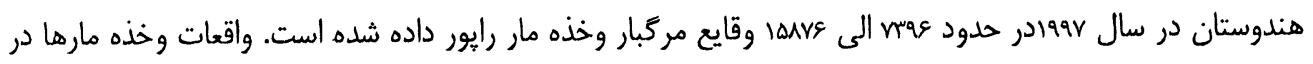
مناطق دهاتى نشين زياد بوده ولى نسبت نداشتن سيستم مكمل رايور دهى و احصائيه ارقام دقيق وجود ندارد. به دارد اله همين دليل در افغانستان نيز ارقام معيّن به دسترس نميباشد (1). وخذه مار : از لحاظ توكسيكولوزى مارهاى افعى كه مربوط به خانوادةf(Crotalidae) و مارهاى خانوادة (Elapidae) كه مار كبرا و coral snake از جملهُ نمايندهكان آن مىباشند، بيشتر حايز اهميتاند. زهر مارهايى افعى به اندازه 
زهر مار كبرا و يا coral snake قوى نيست، اما مارهاى افعى نظر به اينكه مقدار بسيار زياد از زهر خود را داخل بلن شخص و يا حيوان مورد هدف خود مىنمايند، خطر ناكاند.

مارها زهرى به كزيدن كدام علاقةُ ندارند و صرف براى دفاع از خود زهر را توليد مينمايند كه يكانه هدف شان از

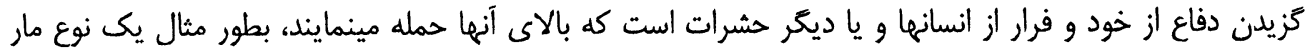

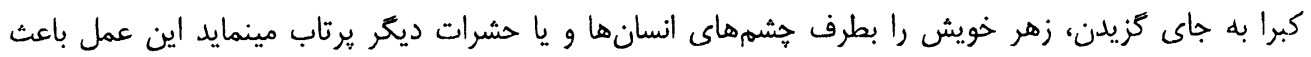

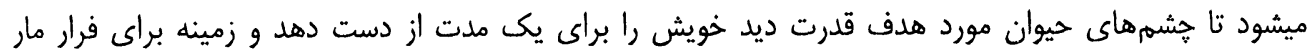

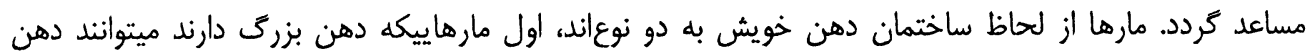

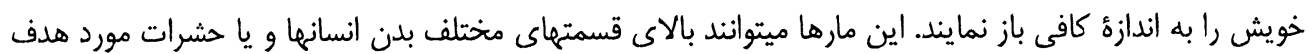

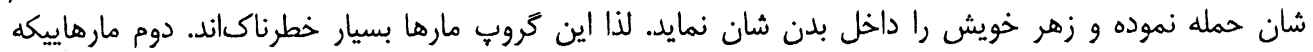

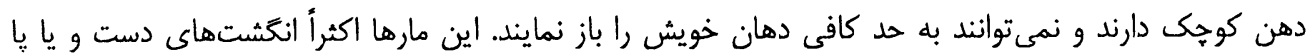

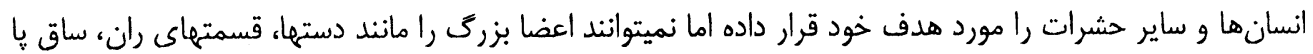

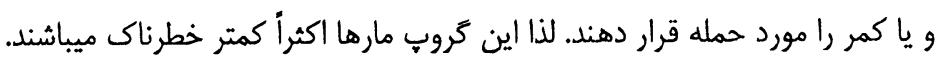

مارها ميتوانند در آب و يا خشكه زندهگى نمايند. يك تعداد اشخاص جنين فكر ميكنند كه مارهاييكه در آب زندهگى

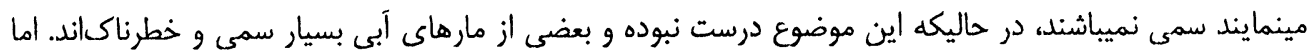

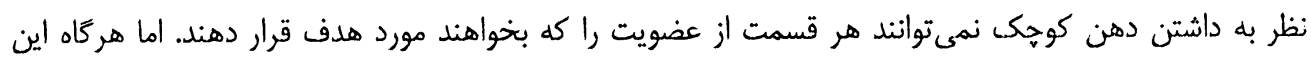

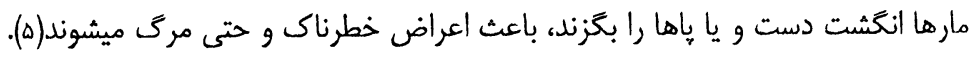
مارهاى زهرى در قسمت قدامى فك علوى شان داراى غدوات زهرىاند كه زهر را توليد و ذخيره مىنمايند. اين

Poisonous

Sriake

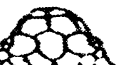

$\sin 3$

2030 Triangle-shaped
head
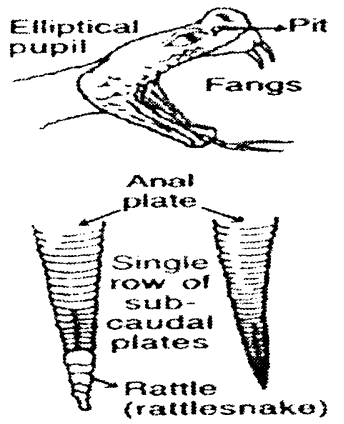

Non-Poisonous Snake

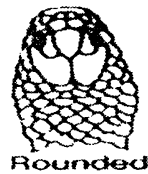

pounder

Pound pexpil

रद No

\section{Anat}

plate

Double

row of subcaudal plates

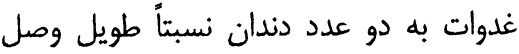
شده است. در هنكام كزيدن، زهر از غدوات ندات زهرى توسط مجراى كه در دندان حيوان

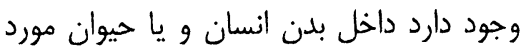
هدف ميشود. اما مارهاى غير سمى دان داراى دندانهاى متعدد ميباشد. نوع جاب ديقي دندان

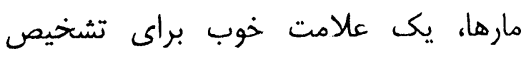
تفريقى مار زهرى و غير زهرى ميباشد. شكل

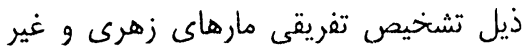
زهرى را نشان ميدهد(ه). 

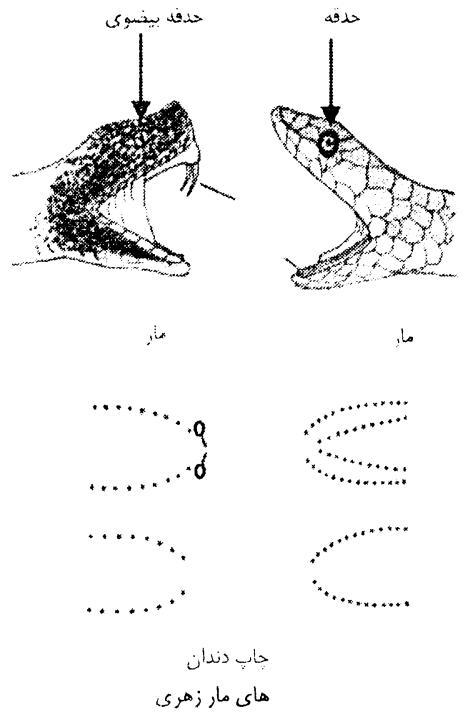

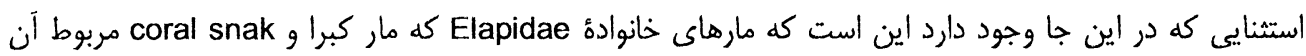

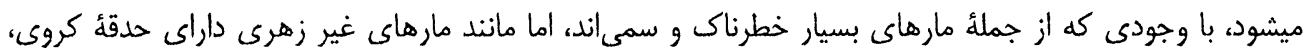

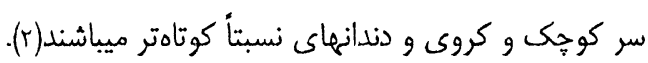

$$
\text { تركيب كيمياوى زهـ مار: }
$$

بيشتر از .ه نوع ماده كيمياوى در زهر مارهاى مختلف دريافت شده است كه اكثريت أنها ساختمان يروتينى

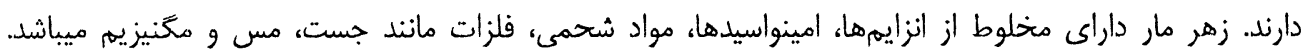

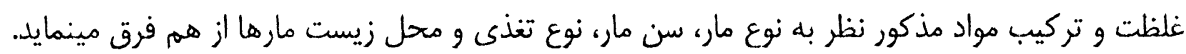
زهر يك تعداد مارها داراى مقدار بسيار كم از آيونهاى غير عضوى و فلزات سمى نيز ميباشد اما غلظت اين فلزات

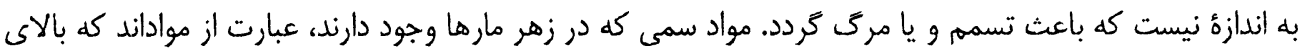

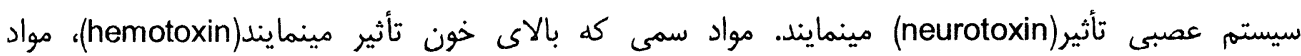
هستامينيك و مواد سمىاند كه باعث تخريب حجرات(cytotoxin) ميشوند(م). از اينكه زهر مارهاى مختلف حاوى يروتينها، ييتايدها و انزايمهاى مختلف ميباشند، لذا نوع ماده سمى و تعداد مواد

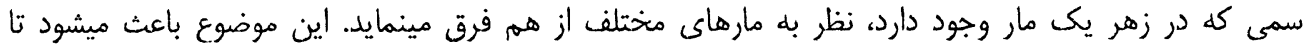

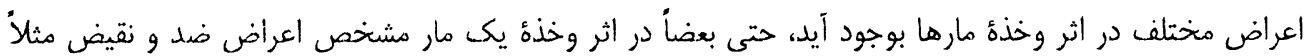

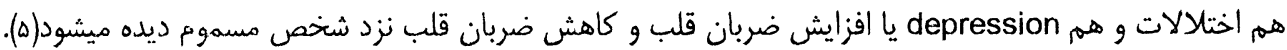


بروتينهاى موجود در زهر مار عبارت از انزايمهالند بطور مثال phospholipase ها و peptidase ها بروتينهاى اند كه بالاى انتقال سيالههاى سيستم عصبى تأثير مى دمايند. توكسينهاى عمده موجود در مارهاى مختلفه قرار ذيل ميباشد:

Neurotoxin-1

نيوروتوكسين موجود در زهر مار، باعث نهى عمل depolarization حجرات عصبى و يا نهى انتقال سيالههاى

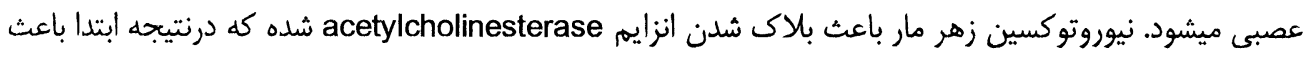

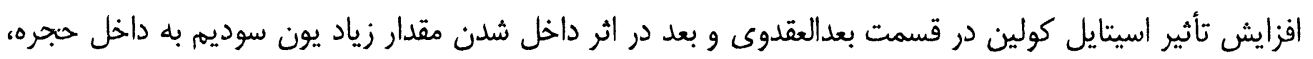

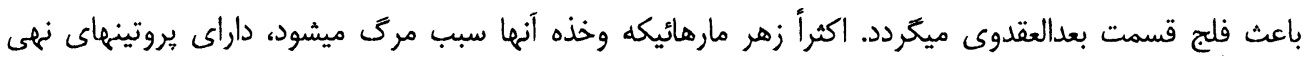

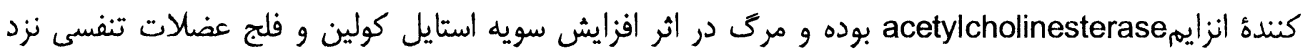
شخص بوجود مياًيد بخصوص زهر مار كبرا (r).

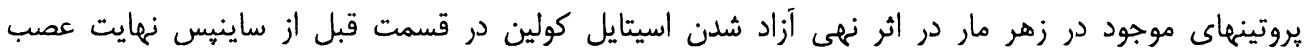

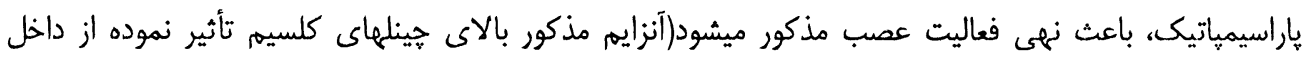
شدن كلسيم به نهايت عصب باراسيمباتيك جلوكيرى مينمايد).

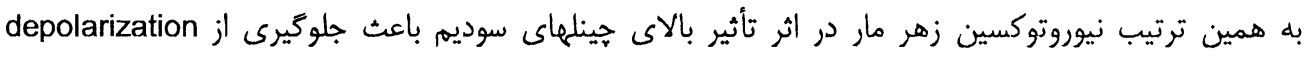

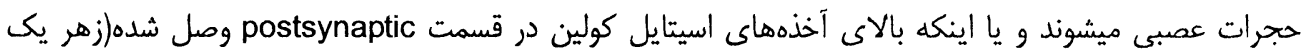

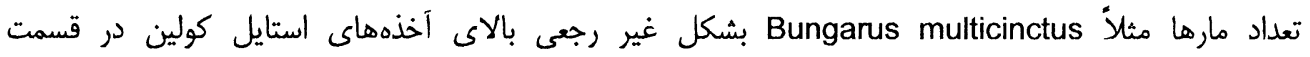
postsynaptic

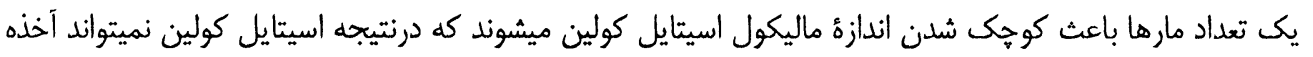

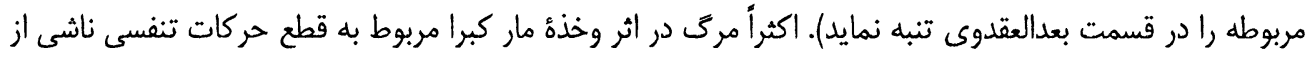
بلاك شدن انتقال سياله عصبى به عضلات سيسته تنفسى ميباشد (ه).

Cytotoxin-2

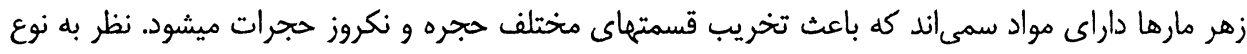

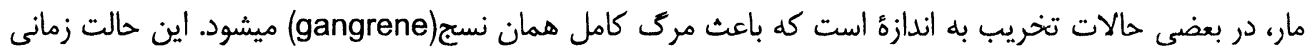

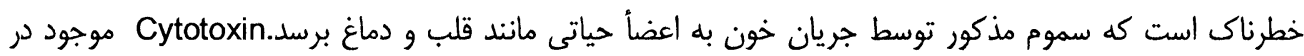

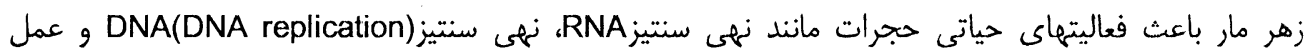
oxidative phosphorylation

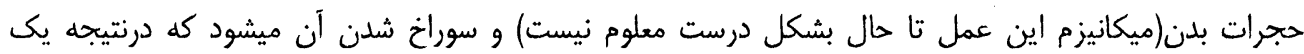
مقدار زياد آب و الكتروليتها داخل حجره شده و واعث بالئ ياره شدن حجره ميكردد. 
Cytotoxin ها نظر به ميكانيزم تأثيرشان به سه نوعاند. انواع اين سموم و مقدار آنها نزد مارهاى مختلف از همم فرق مينمايد)(ه).

Phospholipases - a

زهر مار داراى تعداد زياد از انزايمهاى Phospholipase ميباشد. انزابمهاى مذكور باعث تخريب غشأ حجروى

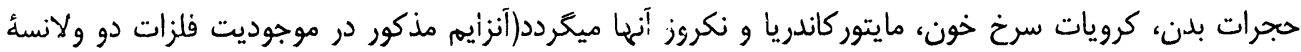

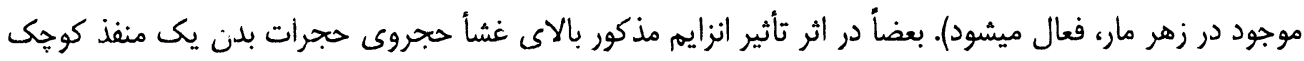

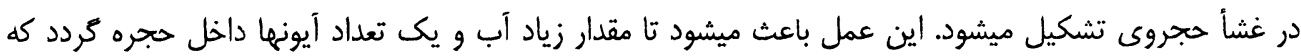

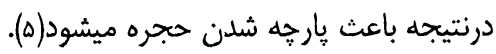

Cardiotoxins $-b$

زهر مار بخصوص مار كبرا داراى مواد سمىاند كه بالاى عضلات قَلبى تأثير نموده و از تقلص آنها جلوكَيرى،

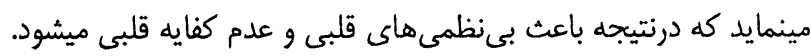

Cardiotoxin قلب(حجرات تنبهى يا pacemaker) و ساير عضلات بدن ميگردد. زهر يك تعداد مارها دارإى توكسين بنام Sarafotoxin رفتن فشار و حتى هار جه شدن اوعيهها ميخردد(ه).

Blood cell toxins -C

( phospholipase Ar)phospholipase زهر بعضى از مارها نظر به داشتن يك نوع انزايمهاى خاص مانند

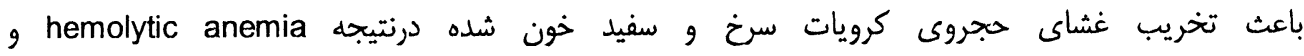

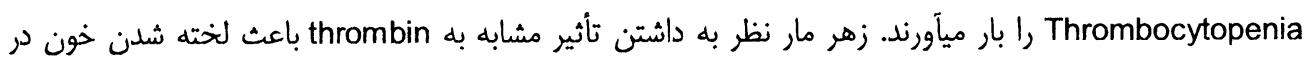

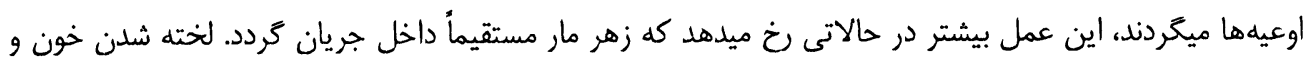

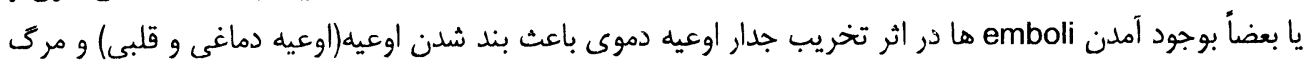

ميشود)(ه).

انتانات ناشي ازوخذه مار:

لعاب دهن زهر مار حاوى انتانات مختلفه ميباشد، بطور مثال لعاب دهن crotalid داراى انواع مختلف أن Clostridium.Proteus

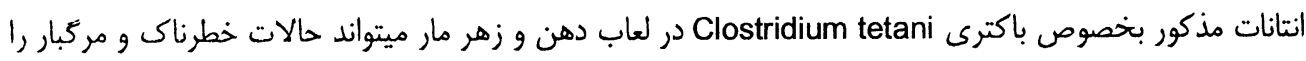

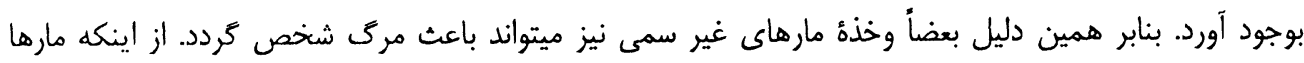


اكثراً ياها را مورد حمله قرار ميدهند، لذا ممكن لعاب دهن مار با باكترى تيتانوس ملوث نباشد، اما ملوث شدن زخم بائم

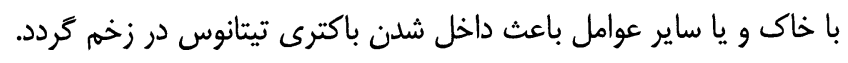

اعساض مسى ناثى ازوخذةهار:

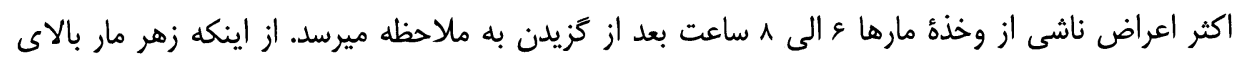

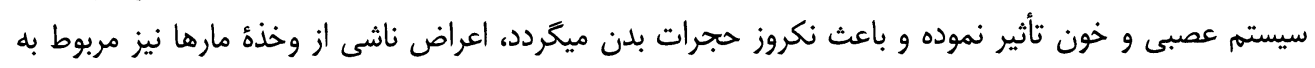

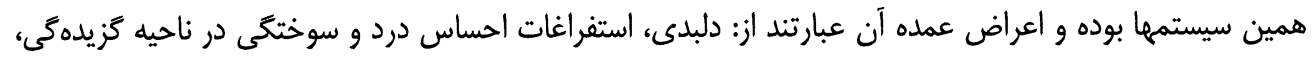

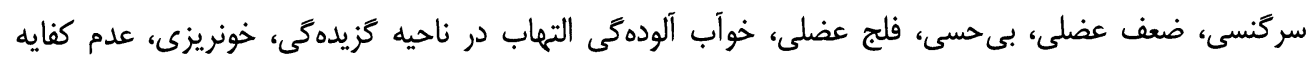

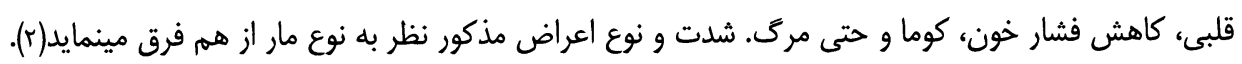
تداوى:

\section{1- كمك هاى اوليه:}

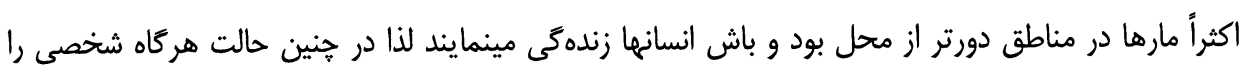

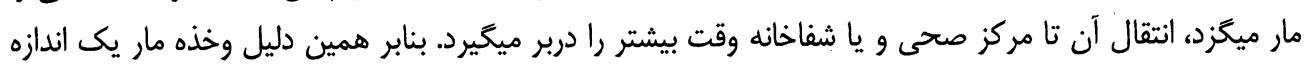

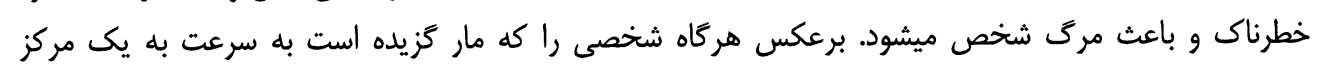

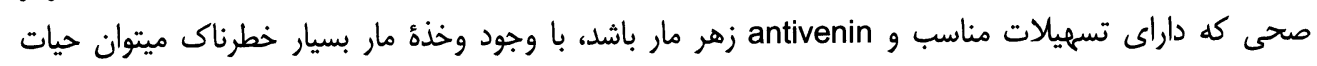
شخص را نجات داد. انجام دادن كمكهاى اوليه طبى نزد شخص مار تزيده از اهميت خاص حياتى برخوردار است. در اين حالت اولتر از

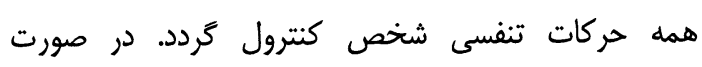

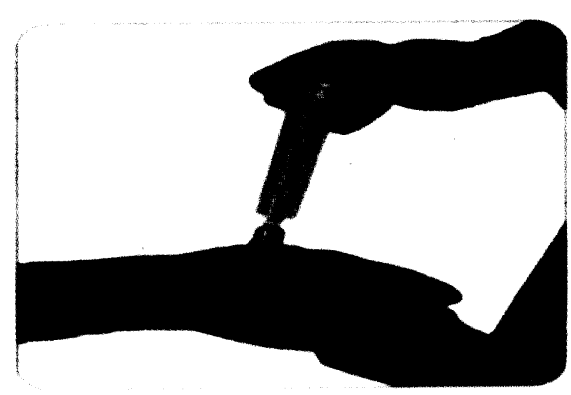

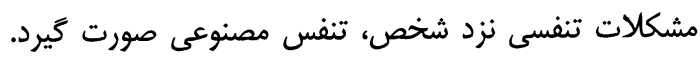

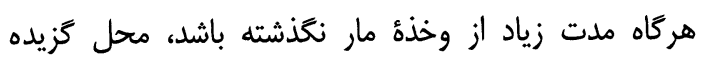

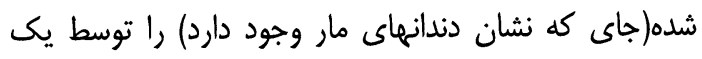

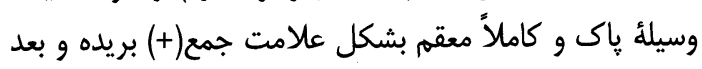

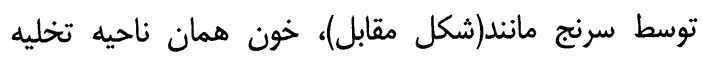

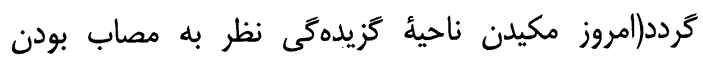

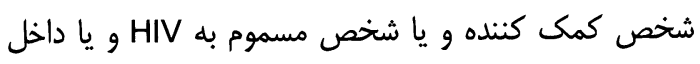

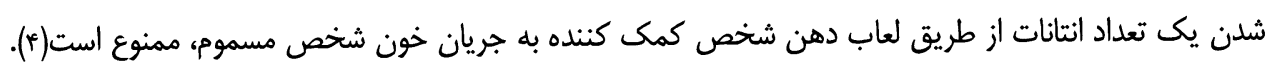
r - ت تداوى با Antivenin بهترين طريقه براى نجاث از مرك نزد اين جنين اشخاص مار كزيده شده استفاده از antivenin است. 
اكثراً براى ساختن antivenin از زهر جهار نوع مار افعى مربوط به خانوادة(Crotalidae) استفاده ميشود. زيرا زهر

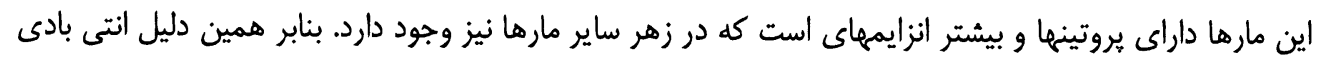

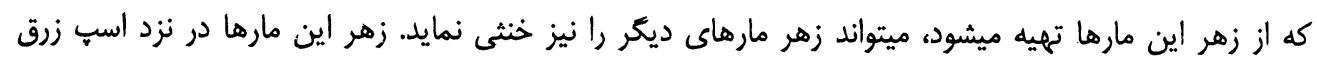

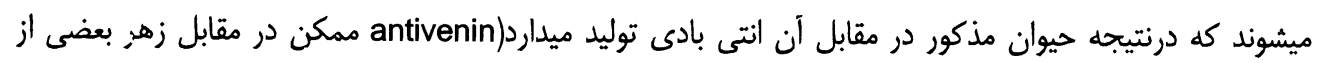

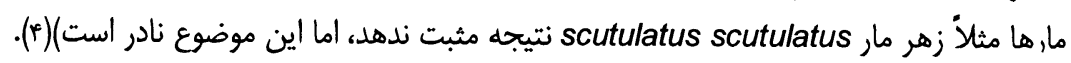

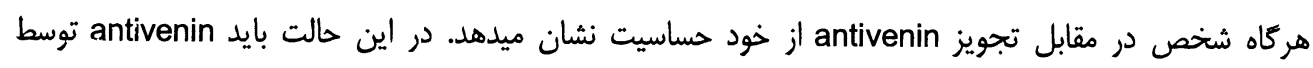
normal saline ضرا ميتوان به دوز Antivenin

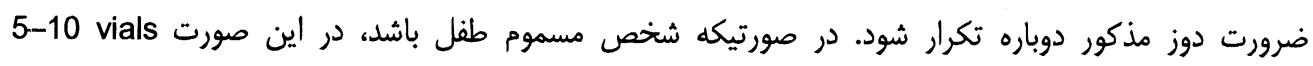
Antivenin

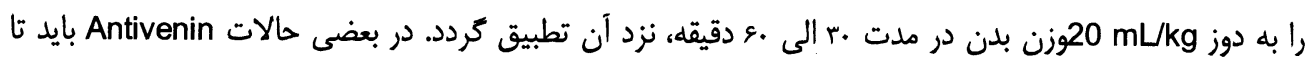

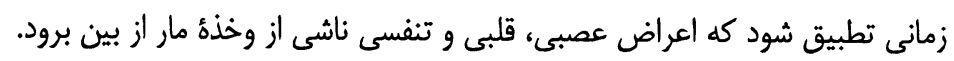

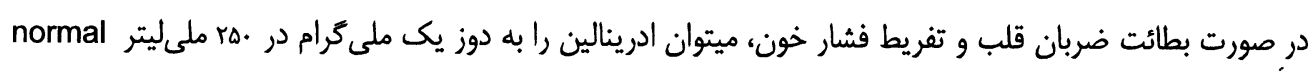

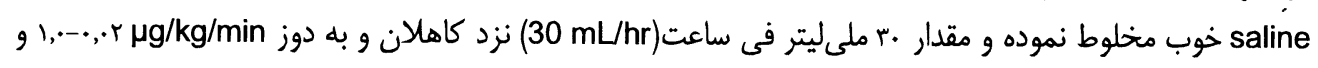

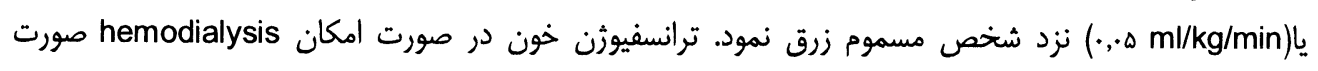

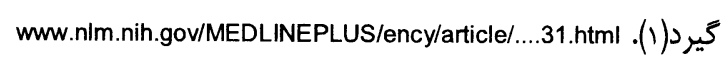
r- r تداوى زخم ناثى ازوخذة مار:

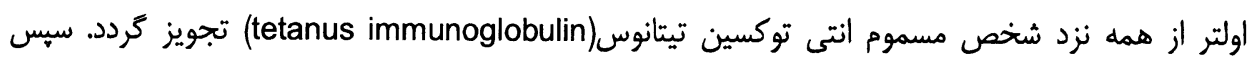

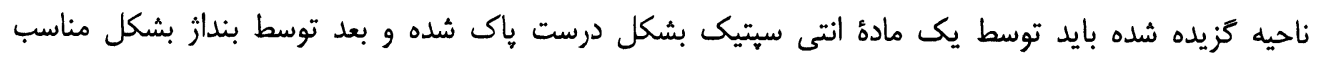
بيجيجانده شود.

هركاه نزد مسموم درد شديد موجود باشد، در اين صورت يك انلجيزيك ماند مورفين برايش تطبيق گرددد. تجويز

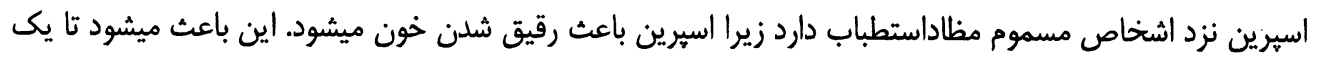

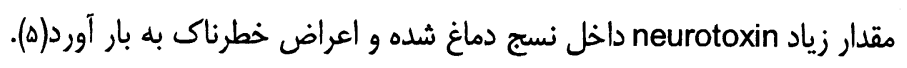

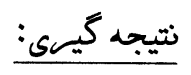

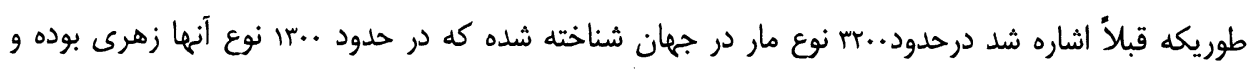

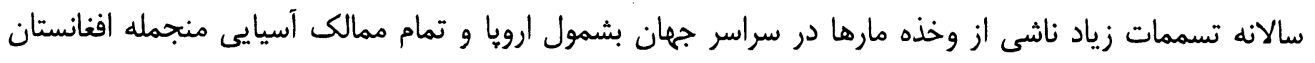


ديده شده است. مارها در محيطهاى مختلف مثلاً آب و خشكه زيست مينمايند كه هر دو كتكورى مذكور ميتواند حالات وخيم صحى را ببار آورد.

زهرمار داراى مواد مختلف سمى ميباشد كه عمدهترينشان عبارت ازمار ميباشند.

مد نظر كرفتن نكات ذيل در جهت جلوكيرى از واقعات مركبار تسممات وخذه مار عارى از فوائد نخواهد بود. - موجوديت Poison center در مراكز صحى. - موجوديت امكانات در مقابل وخذه مارها بخصوص Antivenin - ايجاد كورسماى آموزشى براى اهالى مناطق متذكره. - توصيه يوشيدن بايوش براى دهاقين و اشخاصيكه بيشتر در معرض خطر قراردارد.

\section{:References:}

1-Clinical toxicology of animal venoms and poisons page 528-532.

2-Encyclopedia of toxicology 2005 page-118,140, 141.

3-Principle of toxicology, environmental and industrial applications 2000, page -411 . 4-Poisoning and drug overdose 2007 page 117.

5-R.Waring, G.B.Steventon, molecules of death 2007 page- 291,329-321 , 339. 


\section{عقب ماندكى ذهنى در كودكان}

مقدمه:

عقب ماندكى ذهنى به معناى عملكرد يايين فرد از نظر حافظه و استعداد است. عقب ماندكى ذهنى همجون

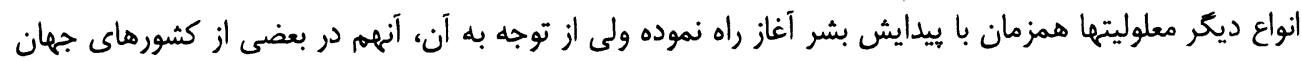
مدت كوتاهيى كذشته است، يعنى توجه به عقب ماندكى ذهنى كذشتهُ طولانى و تاريخ كوتاه دارد. افراد عقب مانده ذهنى از همان آغاز تشكيل نطفه، آغاز تولد و بعد از تولد ميتوانند دجار نارسايى از طريق وراثت و ماند

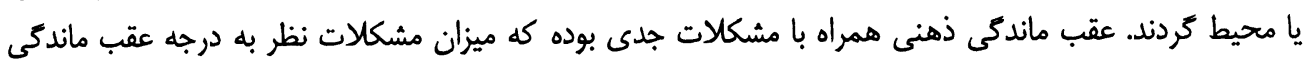
فرد متفاوت است.

عقب ماندگى ذهنى از اوايل قرن دوازدهم هجرى شمسى به عنوان يك مشكل طبى، اجتماعى و روانى مورد توجه

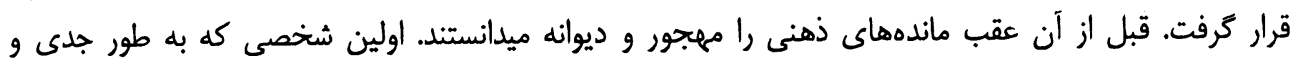

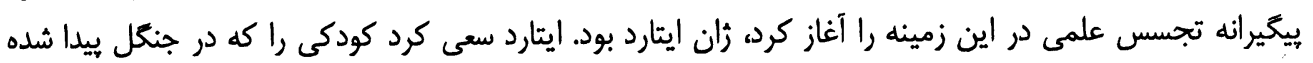

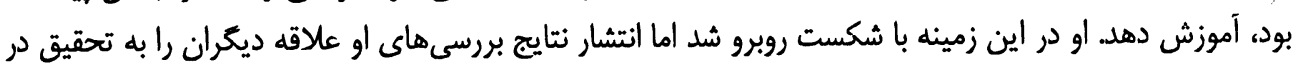
مورد عقب ماندگى ذهنى تحريك كرد.

عقب ماندههاى ذهنى در طول تاريخ بيوسته مورد سرزنش، آزار و اذيت قرار كرفتهاند. تقريباً در ابتداى قرن نوزدهم

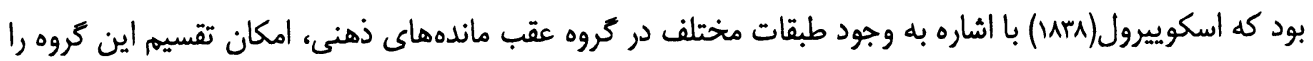

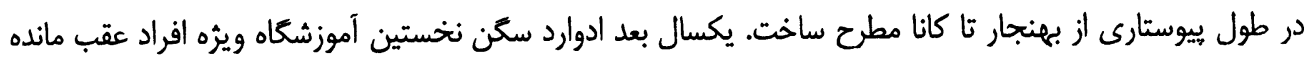

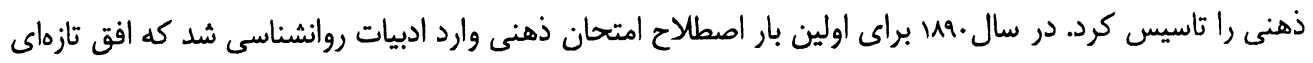

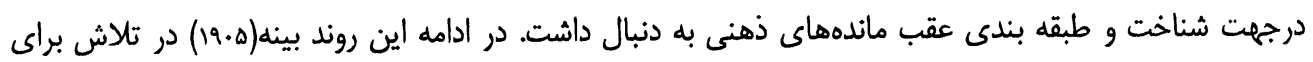

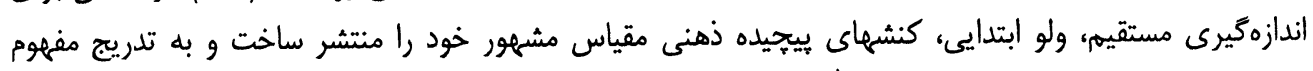

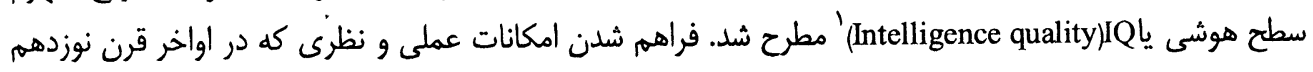

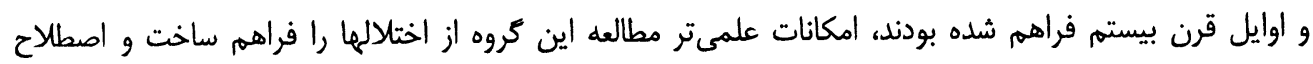
نارسايى ذهنى را مطرح ساخت. عنوانى كه سرانجام در دها سوم قرن بيستم جاى خود رأ را به عقب ماندكى ذهنى ذهنى 


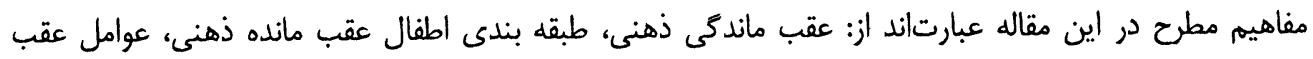

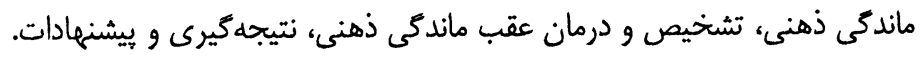

\section{تعريف عقب ماندكى ذهنى:}

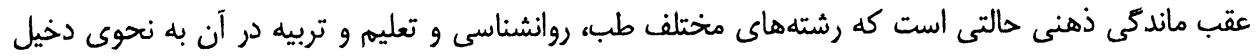

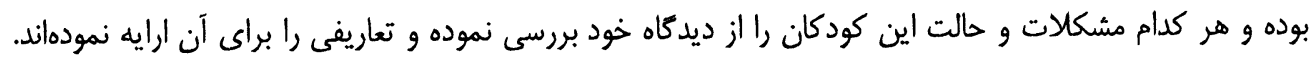

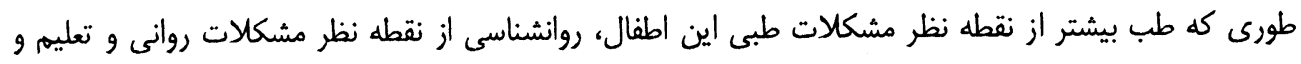
تربيه از نقطه نظر مشكلات تعليمى و آموزشى اين اطفال به اين مساله توجه داشتهاند.

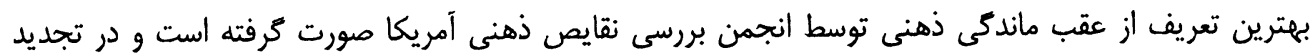

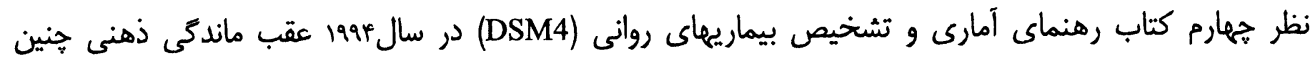
تعريف شده است:

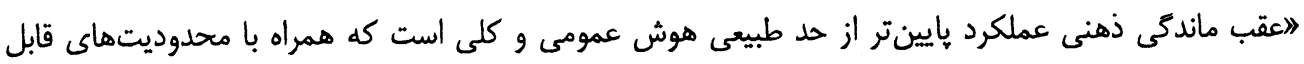

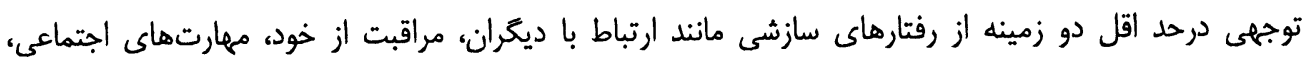

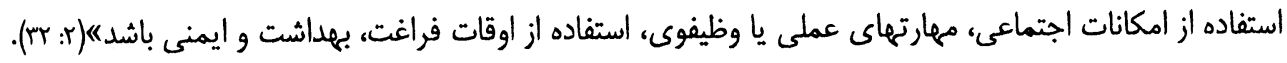

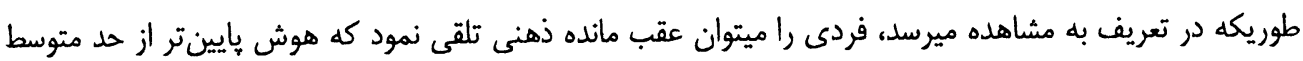

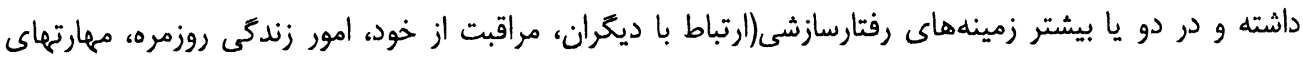

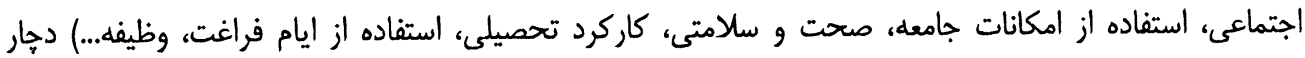

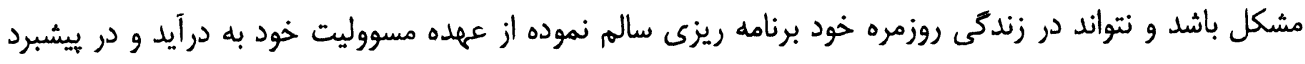
تمام امور محوله دجار مشكل گردد. طبقه بندى اطظفال عقب مانده ذهنى:

اطفال عقب مانده ذهنى داراى خصوصيات و ويزگيهاى مختلف با همديكراند، طورى كه بعضى از آنها

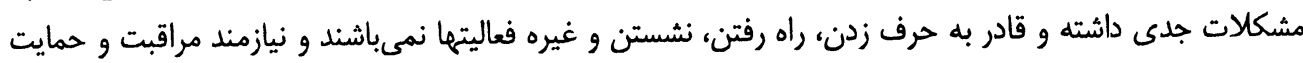

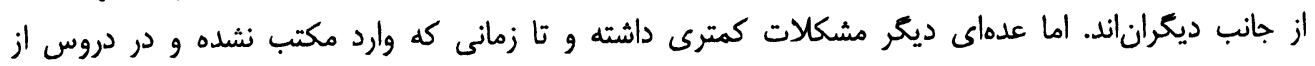

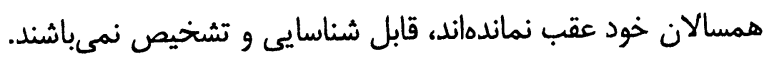
طبقه بندى هاى مختلفى از عقب ماندكى ذهنى از نقطه نظر رشتههاى مختلف(طب، روانشناسى و تعليم و تربيه) به

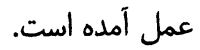

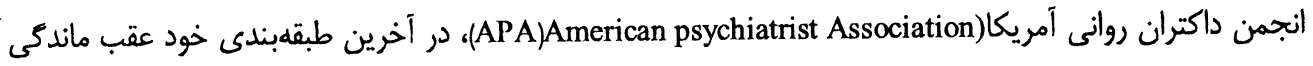

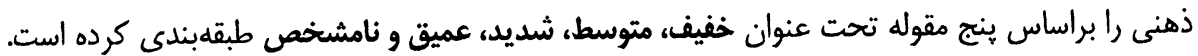




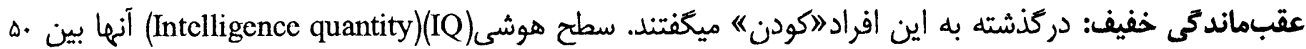

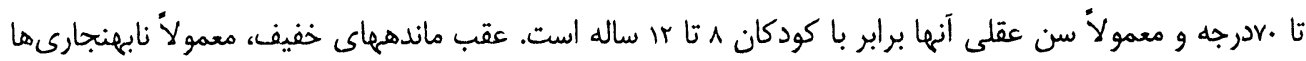

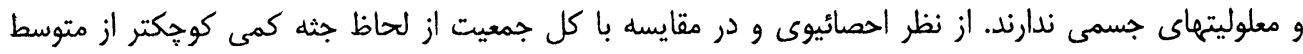

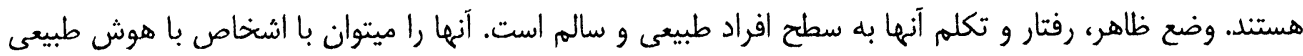

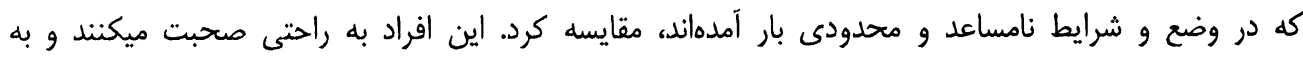

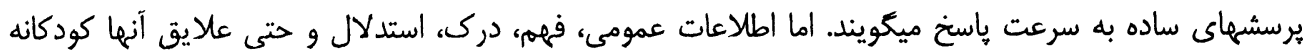

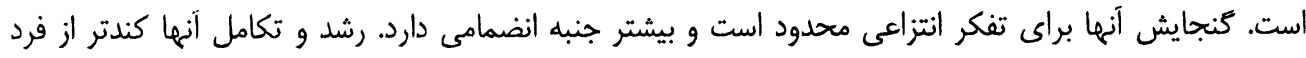

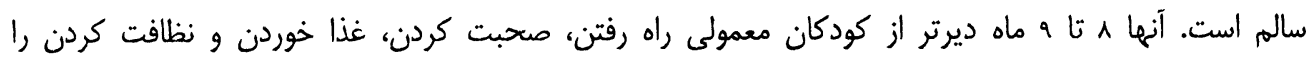

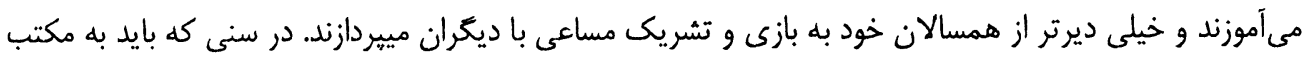

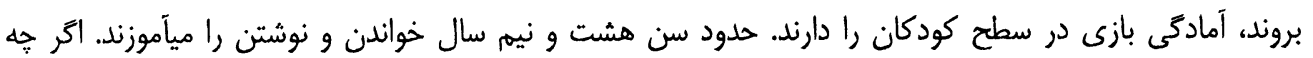

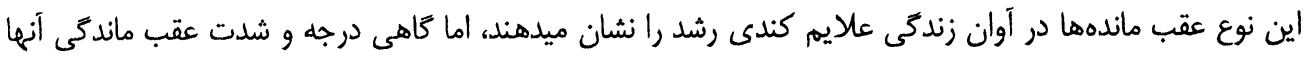

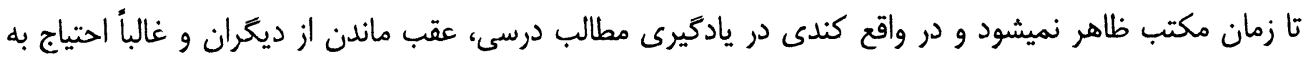

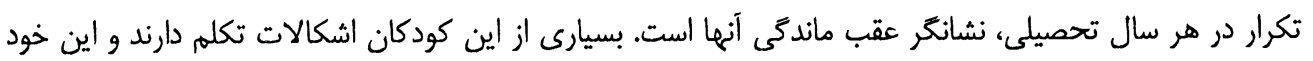

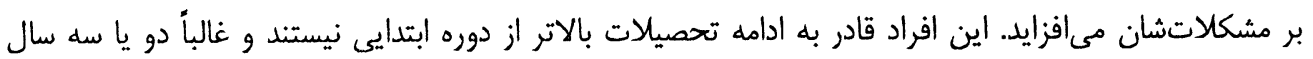

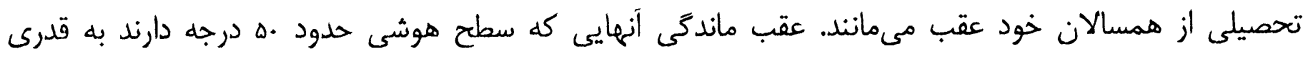

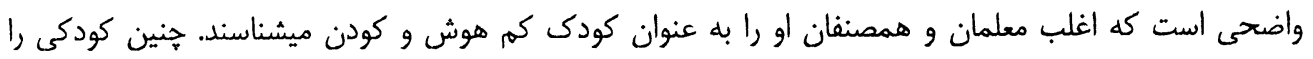

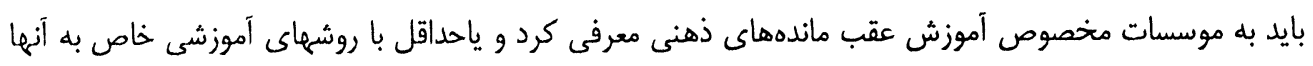

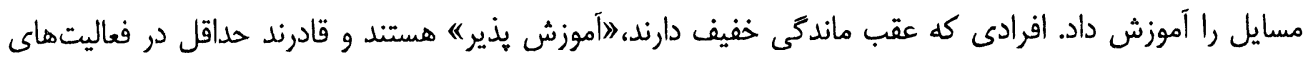

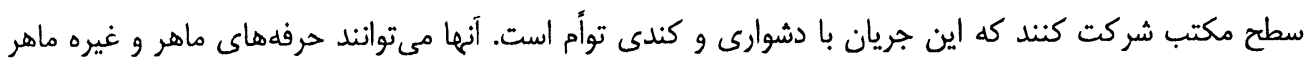

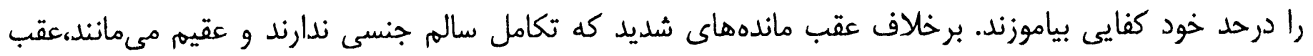

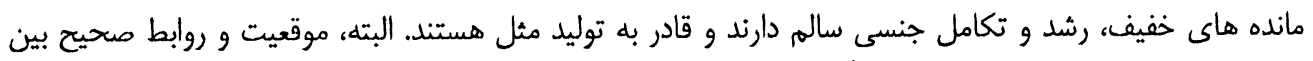

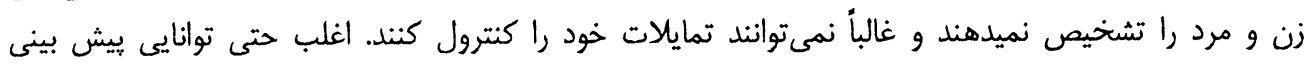

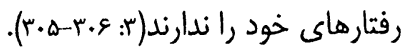

عقب ماندكى متوسط: در كذشته به اين نوع \ابله" ميگفتند و شامل كسانى ميشود كه سطح هوشى بين هץ تا .ها

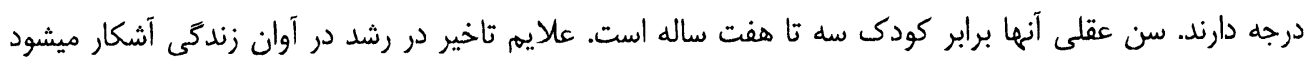

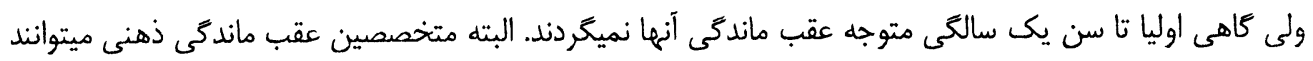

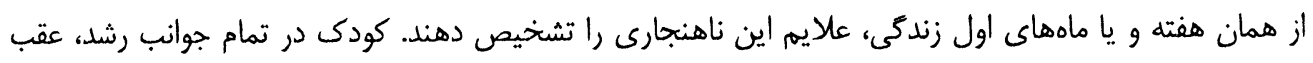

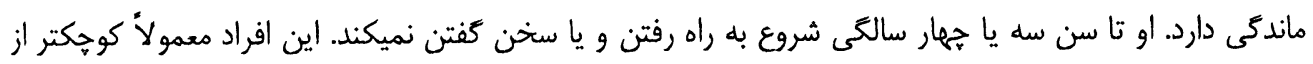

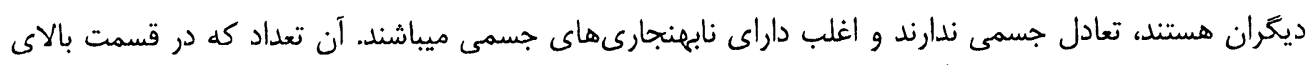

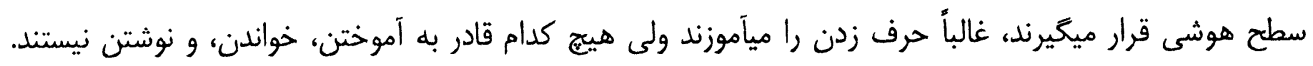


تحصيل در مكاتب عادى و هر فعاليت ديگرى كه به ابتكار، خلاقيت، تفكر انتزاعى و توجه مداوم نياز دارد، برايشان

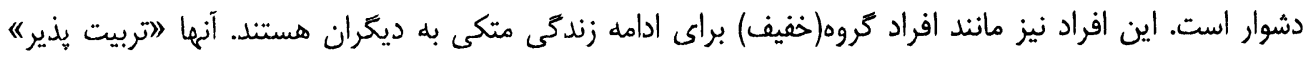

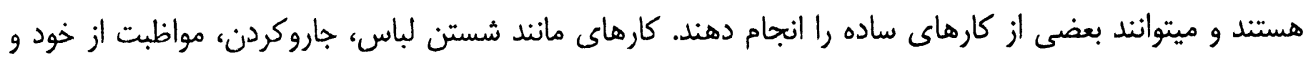

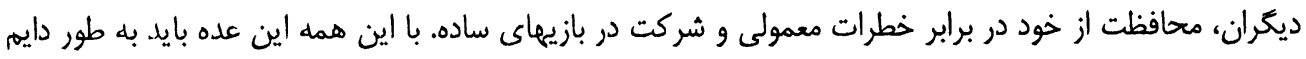

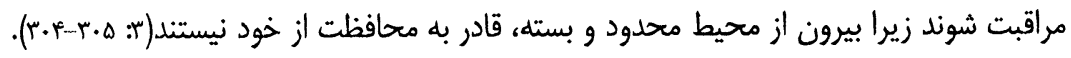

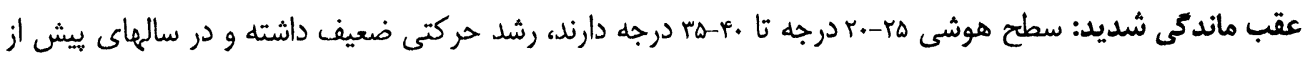

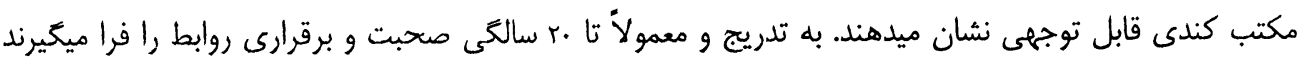

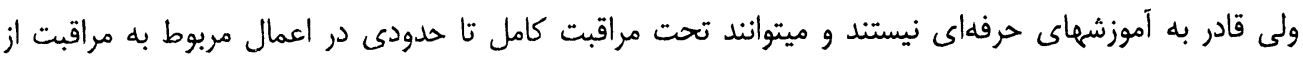

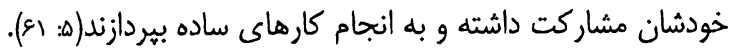

ادراى اين گروه نسبت به عقب ماندههاى عميق بهتر است و از لحاظ عاطفى بسيار سريع تحت تاثير ديخران قرار

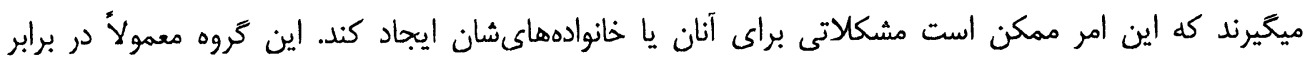

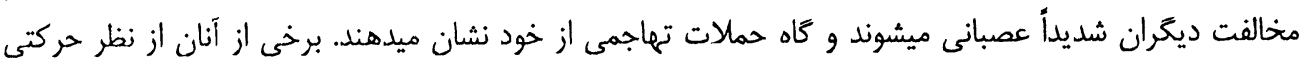

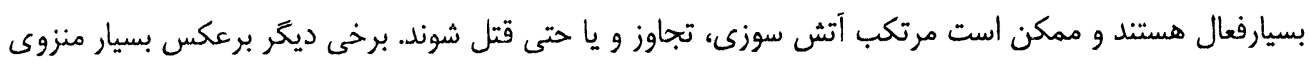

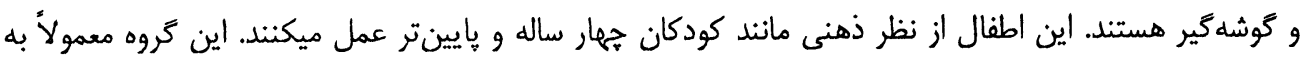

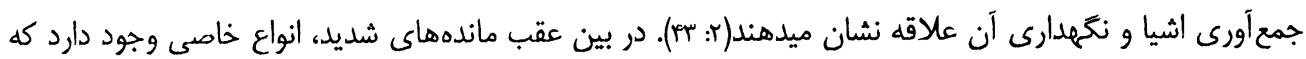

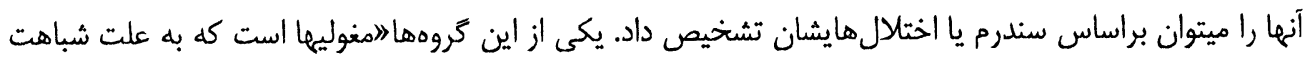

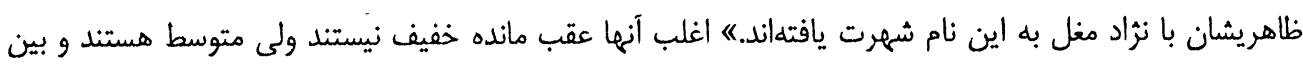

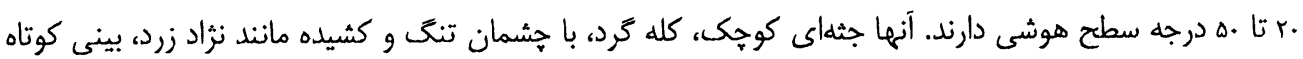

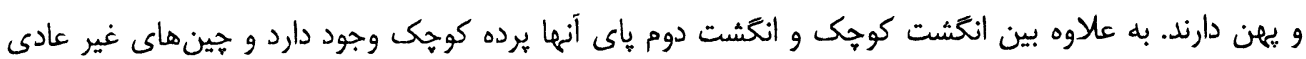
دركف دستان آنها ديده ميشود(ب: ب.r).

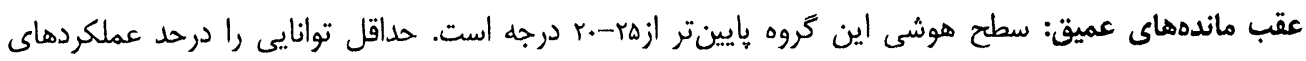

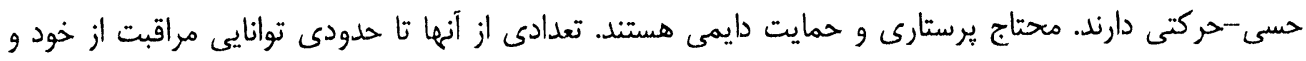

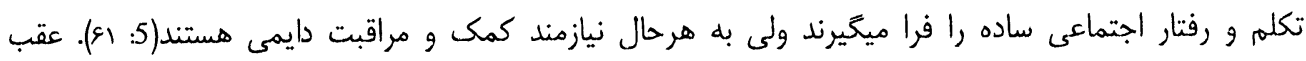

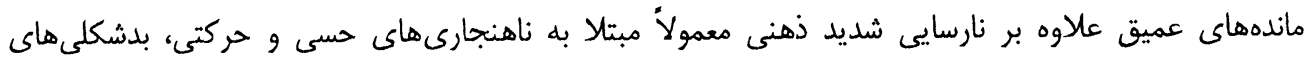

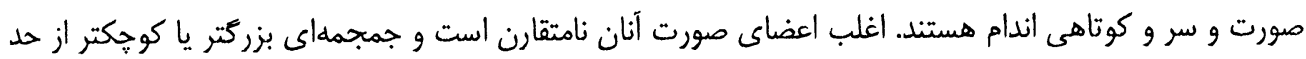

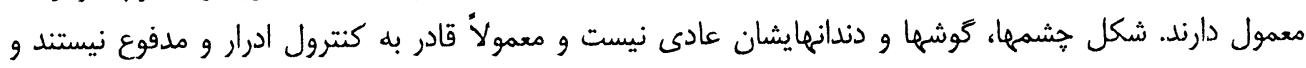

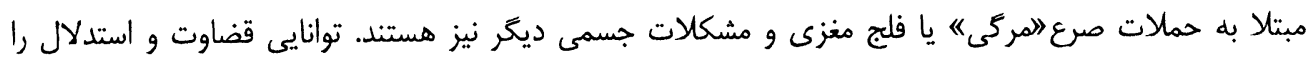

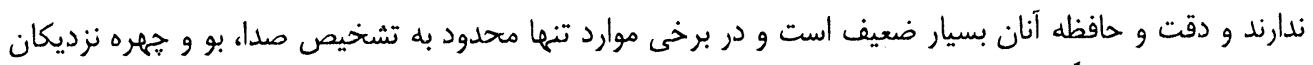

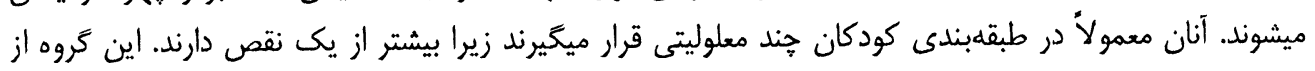

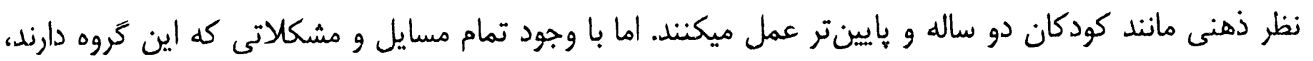




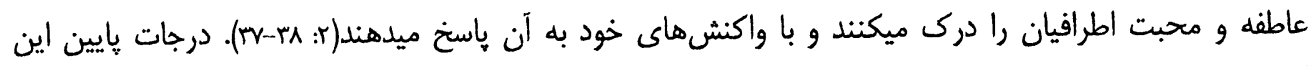

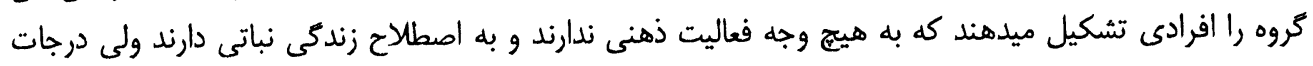

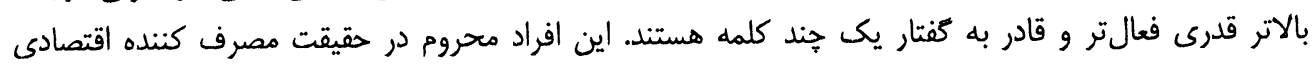

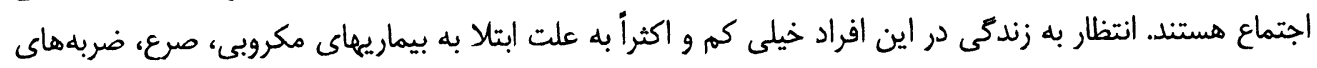

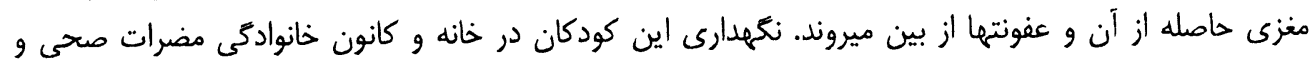

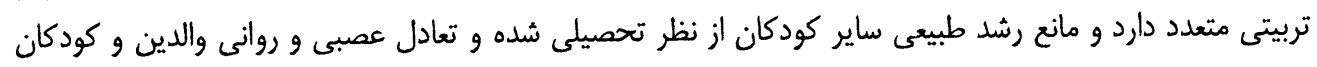

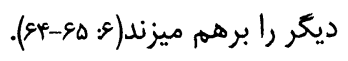

عوامل عقب ماندكى ذهنى:

عوامل مختلفى را كه در ييش از تولد، لحظه تولد، بعد از تولد و عوامل ناشناختهاى كه سبب عقب ماندگى ديى

ذهنى مىشوند، به طور ذيل بيان ميكردد:

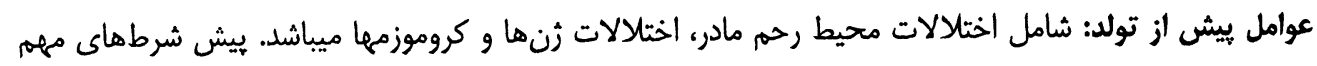

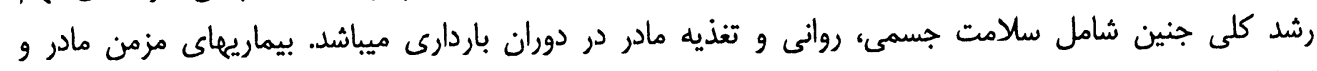

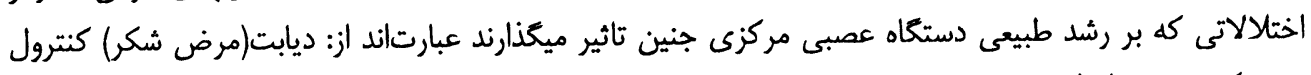

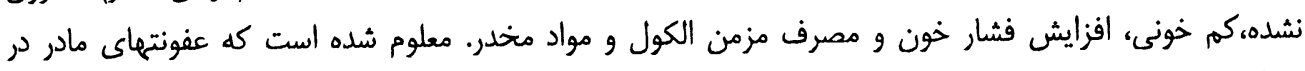

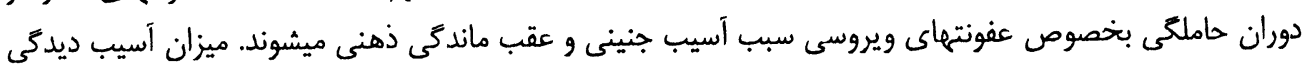

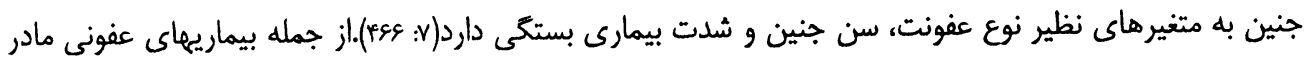

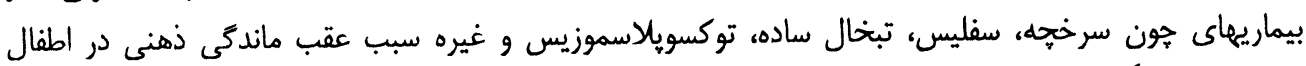

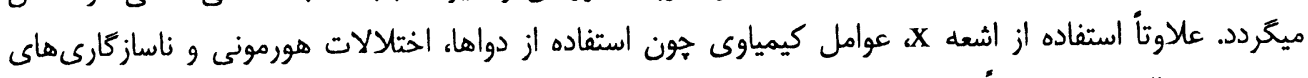

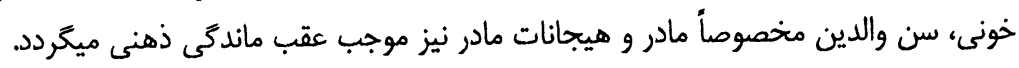

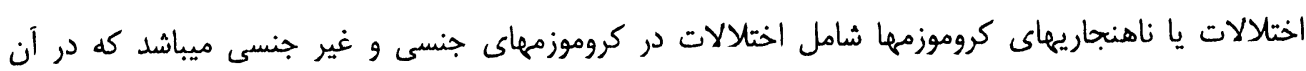

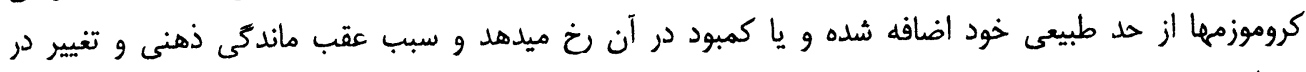

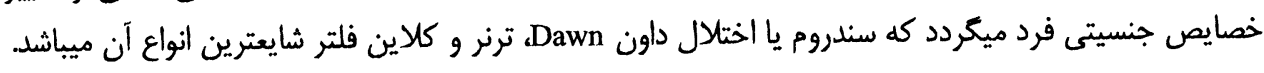

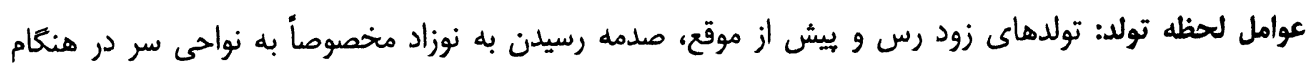

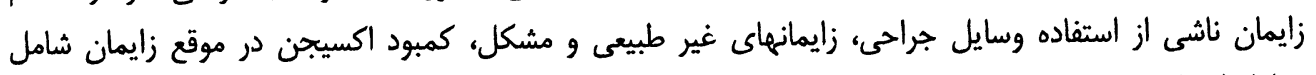
عوامل لحظه تولداند.

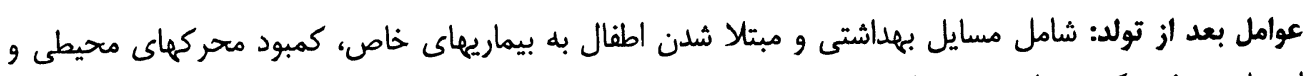

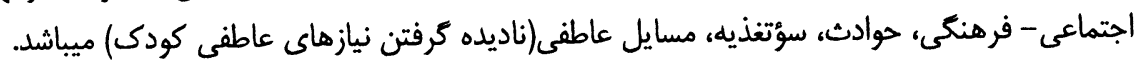


عوامل ناشناخته: شامل عواملى است كه هنوز تشخيص نكرديده و ناشناخته باقى ماندهاند يعنى عقب ماند5ى هاى

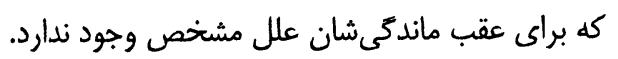
تشخيص عقب ماندگ ذهني:

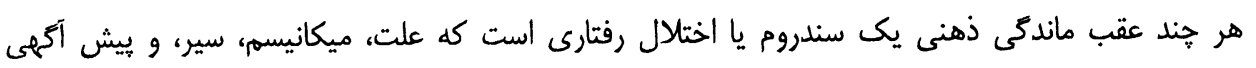

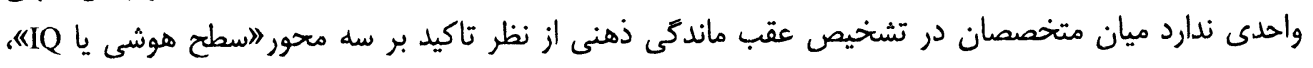

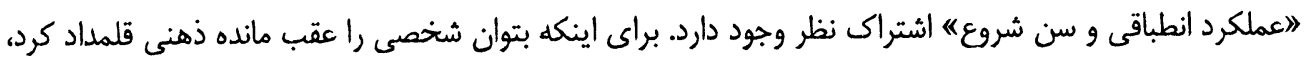

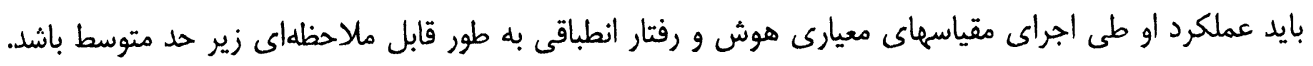

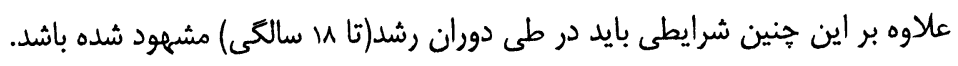

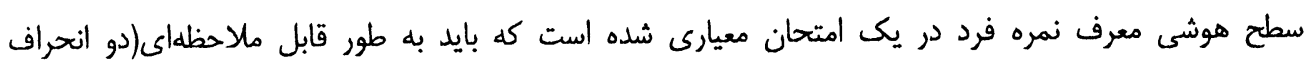

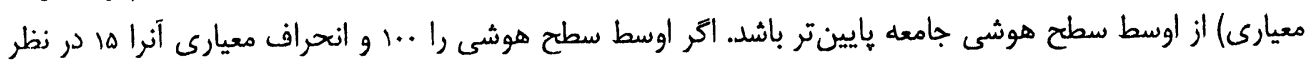

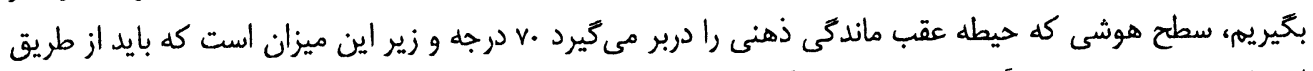

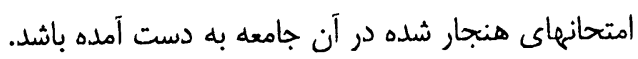

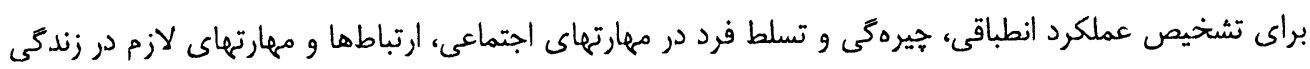

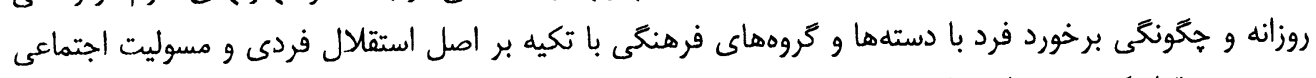

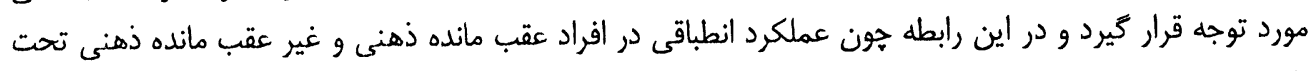

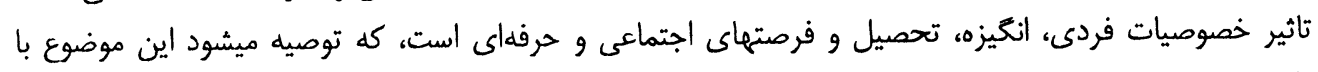

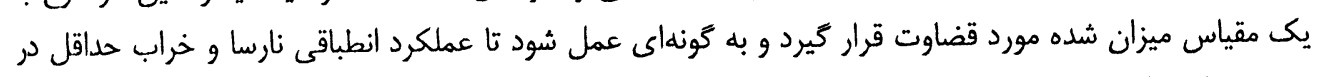

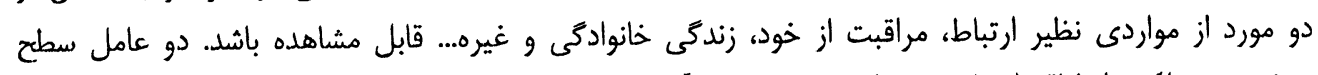

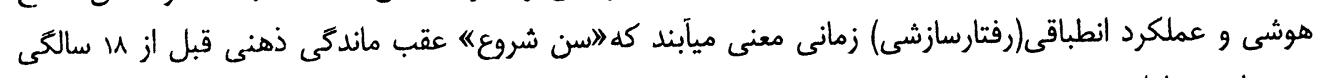

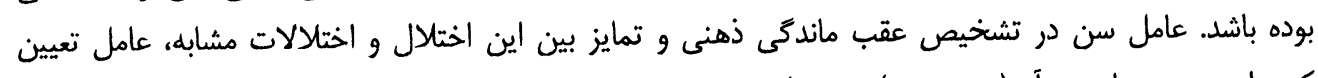

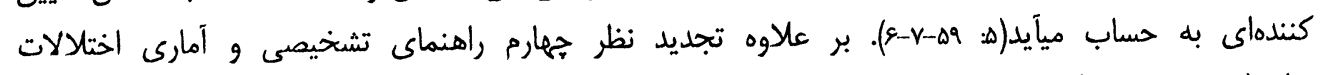
روانى(DSM-IV-TR) ملاكهباى تشخيصى ذيل را براى عقب ماندكى ذهنى بيان نموده است:

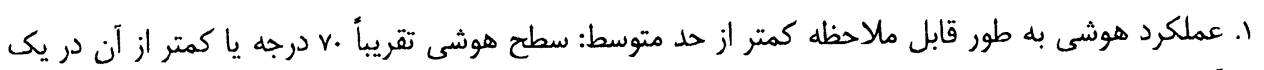

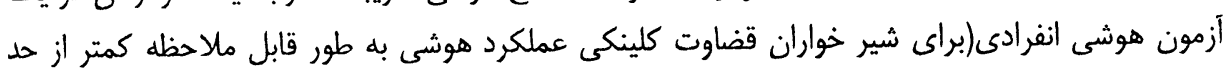

متوسط). r. نقص يا تخريب همزمان در عملكرد انطباقى موجوديعنى كارايى فرد براى برآوردن معيارهاى مورد انتظار در سن يا كروه فرهنكى او)حداقل در دو زمينه زير: 
ارتباط، مراقبت از خود، زندكى روزمره، مهارتهاى اجتماعى/ بين فردى، استفاده از منابع جامعه، خودكردانى، مهارتهاى تحصيلى عملى، كار، فراغت، سلامت رون وايمنى.

$$
\text { r. شروع اختلال قبل از ها سالكى است. }
$$

بر حسب ميزان شدت كه سطح تخريب هوشى را نشان ميدهد كود كذارى كنيد: • عقب ماندكى ذهنى خفيف: سطح سطح هوشىهـ--هـ تا تقريباً. درجه.

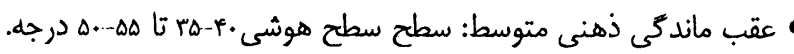

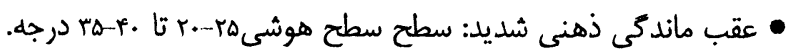

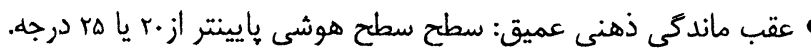

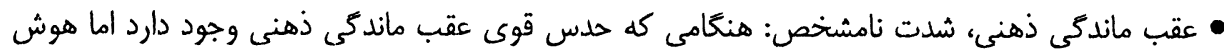

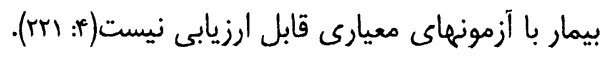

تداوي:

كرجه براى عقب ماند5ى ذهنى تداوى خاصى وجود ندارد اما مداخله به موقع ميتواند رشد عقلانى و جسمانى

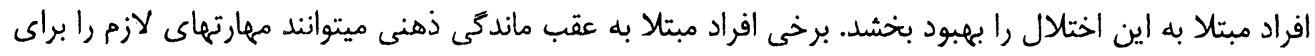

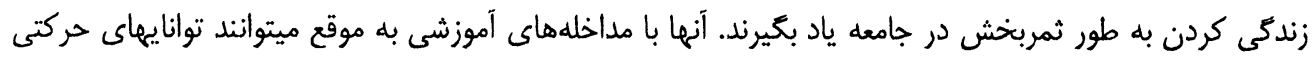

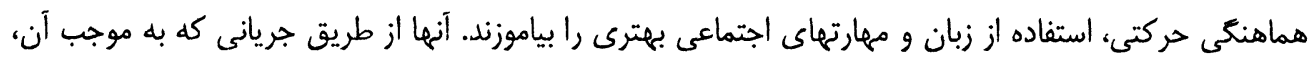

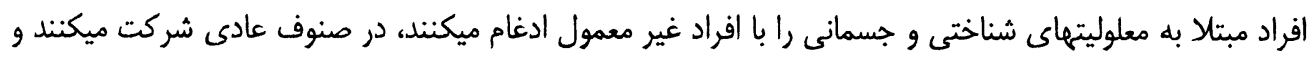

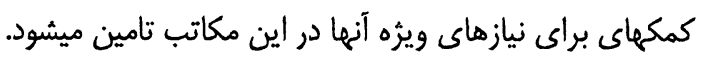

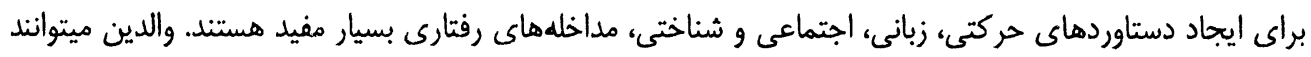

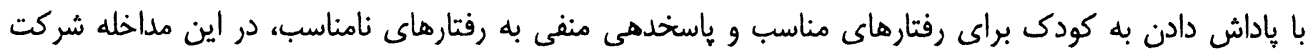

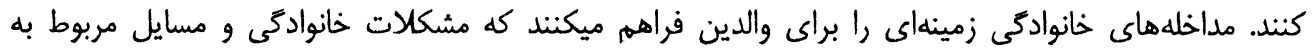

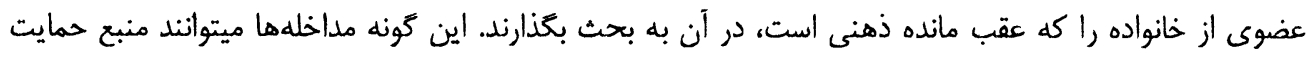
مهمى باشند(8): 251:250).

همجنان بهترين راه تداوى عقب ماندكى ذهنى ميتواند بيشكيرى(وقايه) اول، دوم و سوم باشد.

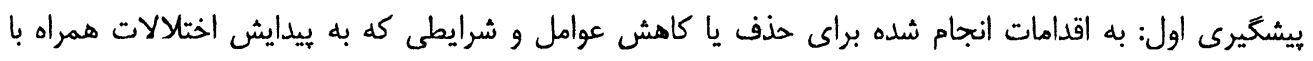

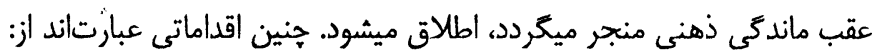
ا. افزايش آكاهى و اطلاعات عمومى مردم در مورد عقب ماندگى ذهنى. r. تلاش مستمر متخصصين صحت براى تامين و بهبود تدابير صحت عمومى. 
r. وضع قوانين براى تامين مراقبت مطلوب مادر و كودك.

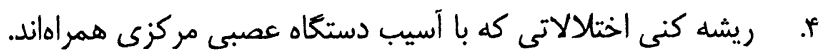

مشاوره خانوادهى و رُنيتك سبب كاهش ميزان بروز عقب ماندگى ذهنى در خانوادههاى ميشود كه داراى سابقه

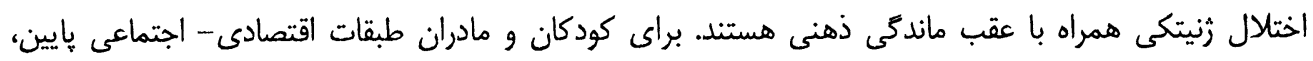

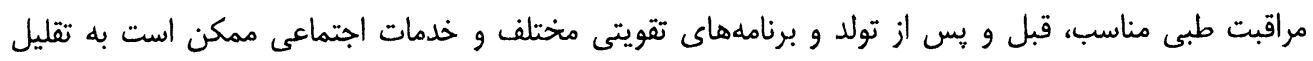
عوارض طبى، روانى و اجتماعى كمك كند.

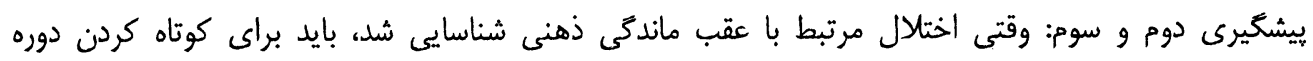

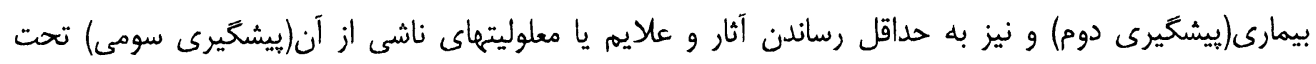
تداوى قرار كيرد(y) (rva-pvs). نتيجه

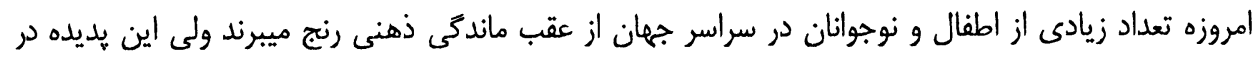

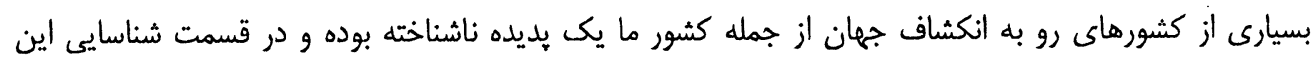

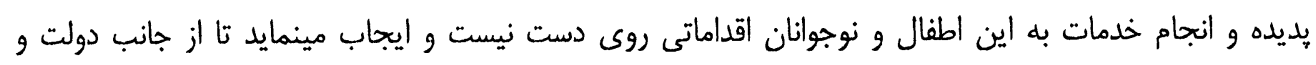

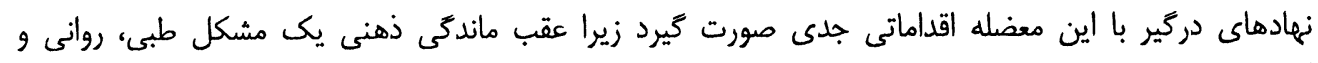

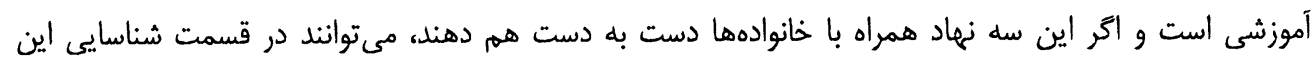

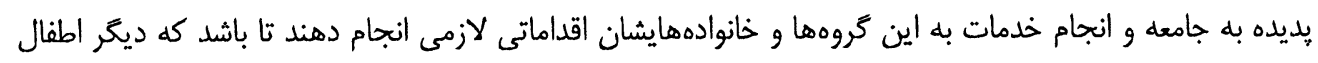

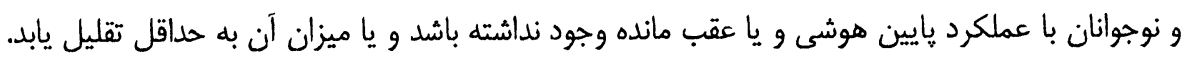

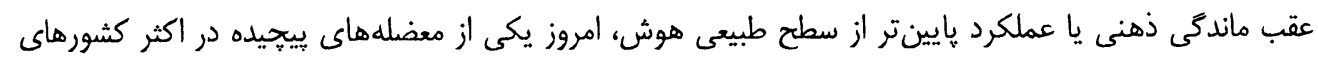

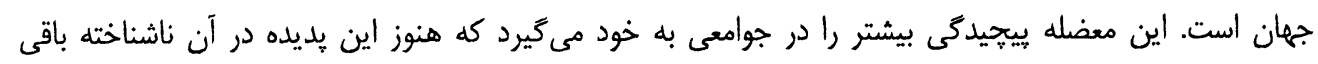

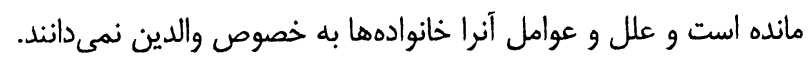

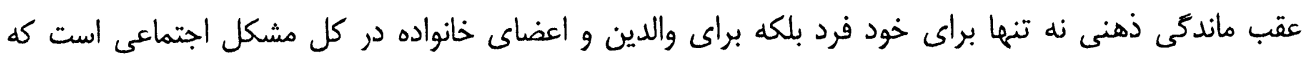

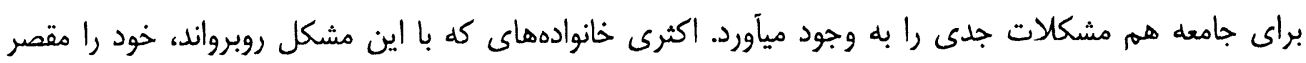

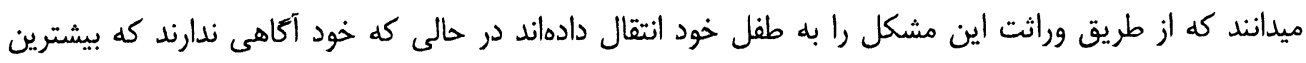

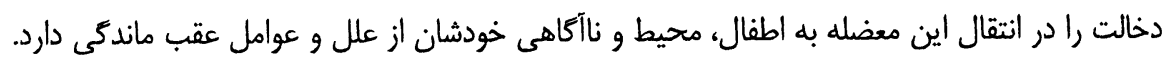

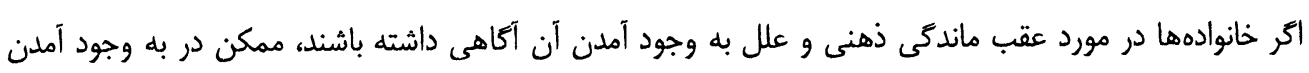

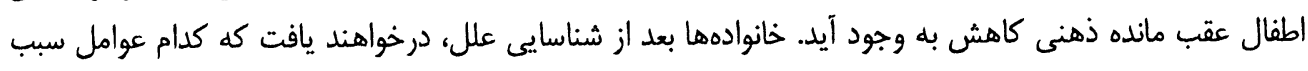

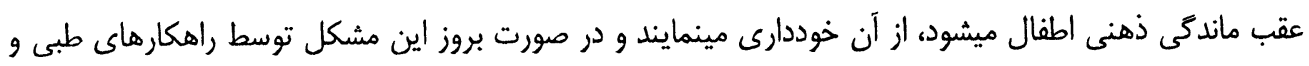
آموزشى در صدد به حداقل رساندن مشكل بر مياًيند. 
در اخير بيشنهادات ذيل جهت كاهش در ميزان عقب ماندگى ذهنى و ساير انواع معلوليتها تقديم است: • آكاهى مردم و جامعه از علل معلوليتها و در نتيجه به كاركيرى شيوههاى بيشكيرى توسط رسانهها. • آكاه ساختن شاكردان و محصلان با استفاده از برنامههاى مستمر آموزشى در مكاتب و موسسات آموزشى. • • آكاهى دادن به افراد در آستانه ازدواج. • انجام آزمايشماى خون براى ازدواج. • • (مشوره با داكتر متخصص هنكام ازدواجهاى خانوادىى. • افراد در آستانه ازدواج بايد قبل از قبل از وجود بيماريهاى ارثى موجود در خانواده يكديكر را مطلع سازند و با نائ مشورت طبيبان متخصص توصيههاى لازم را دريافت نمايند. • • ل اطمينان از عدم ابتلا به بيماريهاى مقاربتى قبل از ازدواج يا قبل از حمل. • مراقبت صحى در زمان حمل، دوران حمل، و بس از تولد. • دقت لازم براى جلوكيرى از ابتلاى ما درباردار بخصوص در سه ماه اول باردارى به هركونه بيمارى. • تغذيه صحيح مادر باردار و كودى از بدو تولد. • استفاده ازدواها و ويتامينها با تجويز داكتر.

بلاخره توجه به زندگى كودى يس از تولد، تغذيه مناسب، واكسنياسيون به موقع، معاينه مرتب طفل در ماهها و سال

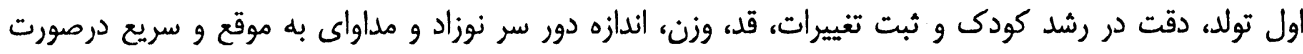

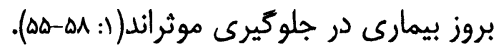




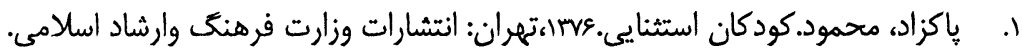

ז. سيف نراقى،مريم وعزت الله نادرى. روانشناسى كودكان عقب مانده ذهنى و روشهاى آموزش آنها. هـזّا، تهران: انتشارات سمت.

r. شاملو، سعيد. آسيب شناسى روانى.rیזו،تهران: انتشارات رشد.

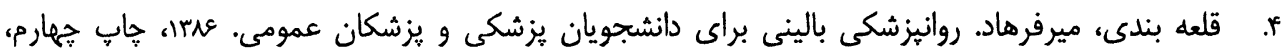
تهران: تشر طبيب.

ه. لطفى كاشانى، فرح و شهرام وزيرى. روانشناسى مرضى كودك.ایזا، تهران: انتشارات ارسباران. g ميلانى فر، بهروز. روانشناسى كودكان و نوجوانان استثنايى.برrا، تهران: نشر قومس. V. هارولداى. كايلان، بنيامين جى. سادوك. خلاصه روانيزشكى، علوم رفتارى، روانيزشكى، بالينى. رهrا، (ترجمه

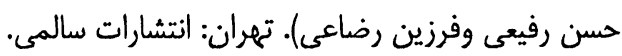
^ هالجين يَى، ريجارد و سوزان كراس ويتبورن. آسيب شناسى روانى: ديدگًاه هاى بالينى درباره اختلالهاى روانى. 


\title{
Mental Retardation in children
}

Pohyalay Spozhmay Oriya

Faculty of psychology and Educational sciences

\begin{abstract}
:
Mental retardation is a condition indicated by an IQ below 70 that began during the developmental period and is associated with impairment in adaptive functioning.

Mentally retarded children have different characteristics with each other. For example, some of them have scrious problems such us, inability to speak, walk, and sit and some other functions and they are in need of take care and support of others. But some others have fewer problems and they cannot be recognized until their entrance into school and not getting their lesson as their math.

American psychiatry association (APA) classified mental retardation in to five categories of borderline, mild, severe, profound and unspecified. Causes of mental retardation are: womb environment disorders, gen and chromosomes disorders, mothers chronic daises (diabetes, anemia, high blood pressure, toxoplasmosis, measles , addiction, syphilis, ) Using $\mathrm{x}$ - ray, using drugs, hormonal disorders, blood RH incompatibility, parents' age, mothers emotions, prematurity, lack of oxygen, etc....

In diagnose of mental retardation these points are important: Below-average intellectual and adaptive functioning during the standard intellectualtests, beginning of disorder must be up to 18 years old. In treatment of mental retardation in spite of educational ways, mostly tow ways are common:

Prevention before birth to omit or decrease the factors and condition causes mental retardation and prevention after birth which is a treatment to help the mentally retarded child and to become compatibility with society.
\end{abstract}




\title{
Snake's bite toxicological study
}

\author{
Associated Professor Hafiza Hamid \\ Department of Pharmacology \\ Toxicology branch
}

\begin{abstract}
:
Human are working on venoms from the ancient times . these animal are like snakes, scorpions, spiders and bees. In general they contains proteins, Lipids, Amino acids, enzymes and Histaminoides.
\end{abstract}

There are 3200 kinds of snakes in the world which are known in the snake's biology, among them 1300 kinds are having most dangerous substance which mentioned above.

According to animal bite statistics around the 100000 people are bitten annually by snakes in United States.

Snakes are living in soils and water. It is noticeable that some people think that aquatic snakes aren't more poisonous, this is not true. Because there are some aquatic snakes which risks are rather than other snakes.

The signs of snake's bitten area is a good indicator for snake identification to know about their risk to human health.

Almost 50 kinds of different substances are present in the snake's venoms, generally the most important among them are classified as Neurotoxin(Acting on nervous system), Hematotoxins( acting on blood cells), Cytotoxins( cause cell injury) and Histaminoids(cause allergies).

Whereas snake's venom has composed on different kinds of proteins and peptides therefore their produced symptoms may be distinguishable completely.

Neurotoxins present in snake's venom causes inhibition of depolarization or blocks Acetyl choline esterase enzyme, resulting increase in cholinergic effects. Some cytotoxic compound present in snakes venom cause cell injury, necrosis and gangrene. If the toxin achieve to brain or cardiac cells, thus it produce more serious case of animal biting. Cytotoxin also inhibits the RNA and DNA synthethase.

Phospholipase present it in snake's venoms lyses the cell membrane of RBC and mitochondria.Cardiotoxin acting on cardiac cell and inhibits their contraction, consequently cause arrhythmia.

Saforatoxin is one another toxin present in snake's venom which causes vessel's contraction and hypertension. 
Hematotoxin has phospholipase $\mathrm{A}_{2}$, which is responsible for disrupting of $\mathrm{RBC}$ and WBC membrane, hemolytic anemia and thrombocytopenia. Sometime this toxin acts like thrombin and induce coagulation of platelets, which appears as ambule and vessels abstraction.

Another concern about snake's bite, if the venom is contaminated by bacterial toxin that increases the severity of problem.

TREATMENT: the victim should to be transfered to nearest BHC. If the health center was away from the area first medical aids are preferred in such cases. Administration of Antivenin is the best choice if available the coadministration of Antihistaminic like Corticosteroids drugs is also useful in the treatment strategy. 


\title{
Analysis, Evaluation and uses of macromolecules or Polymers.
}

\author{
Pohanmal Habibullah Farahi \\ Department of Chemersity \\ Kabul University
}

\begin{abstract}
:
In this scientific rescarch article macromolecules or polymers has been briefly analysed and evaluated. The purpose of this article is to differenciate between macromolecules and monomers and also to know the characterization, properties and classification of macromolecules or polymers . Both organic and Inorganic polymers described here .

Different methods for the preparation of macromolecules or polymers also has been analysed.

Finally the uses of macromolecules or polymers in daily life has been mentioned in this scientific research article especially the uses of polyethylene, polypropylene, polystyrene, polymethylmethacrylate, polyvinyl Alcohol, polyvinyleChloride, polyether, polyester have been described in this scientific article.
\end{abstract}




\title{
The Sociologist's idea about the characteristic of industrial and tradition societies
}

\author{
Professor Zabih Allah Rahim \\ Faculty of Sociology \\ Kabul University
}

\begin{abstract}
:
Society and its related concepts are the issues which most sociologists are expressed their ideas in this specific regards. One of these mentioned issues are the type of societies which are classified based on the different factors.

This article mainly focus is drown on the classification of societies according the industrial and traditional characteristics.

The traditional societies are the societies with fewer developments and more complications, which the industrial societies indicate continuously changing with maximum liveliness and progress.
\end{abstract}

Based on the mentioned characteristics the sociologists are using the different terms and concepts to give the exact picture of these societies. Below ideas are expressed by sociologist as they are stating:

George Freedman, one of the western scholar, has been mentioned about two definitions, which are (natural environment) for tradition societies and technical environment for industrial societies.

Ferdenand Tones German's famous sociologist has been used the terms of Gemeinschaft (community) and Gesellschaft (society) for definition of mentioned societies.

Harbert Es Pensar the English sociologist has been divided societies in to traditional harmonic societies and industrial societies.

Emile Durkheim French sociologist division is based on two types of solidarities, which are Mechanic solidarity for (traditional societies) and organic solidarity for industrial socicties.

In order to summarize the mentioned ideas and definition of sociologists regarding these two types of societies the bellow characteristics differentiates these societies from each other.

The traditional societies refers to the societies with very slow and passive mechanism of progresses, less population, limited geographical area of living, open families with large depended members, endogamy marriage system, enough control 
over the family's member, close and strong family relation, and face to face informal relations, less possibilities for vocation improvement and occupation, stable social statues with less choice of improvement and changes, natural social roles which are not gained. These type socicties' efforts are intended to complete their basic needs, such as food provision, cloths preparation and housing arrangement. They are not proceeding for father livelihoods improvement.

The industrial societies are determined by characteristics such as: dynamic system of devclopment, increased population, expanded geographical area, closed families with less members and broken weak relations between families, exogamic system of marriages, less controlling over the family members, very cold ,weak family relation formal social relation, much possibilities for specialization and vocational skill development, individualism, and more chances for occupation, progressive social status, achieved and learned social roles.

In such developed societies the efforts are intended to achieve the fathered standard of living like cultural and refresher comforting needs in addition to completing the basic primary human needs. 


\title{
Research about Dastarnama's formical kind of poems
}

Associated prof.Mohamad Ajan Haqpal

Department:pashto

Faculty of language and literature

kabul univercity

\begin{abstract}
:
Since this (Dastarnama)is a textbook, it should be taught as the original form and for the reason that there are some errors in the rhythm and nomination of the titles of the types of some poems, the teachers and students will possibly pay no attention to them during the lecture.this article was written based on this same need.I hope referring to this article will prove useful and the problem will be solved as much as possible . this should also be taken into consideration that these mistakes have not been made by Khushal khan,the writer of the book.the error look to be made by those who have copied this literary work because Khushal khan certainly understood the types of poems very well.And for the confirmation of our point,we have hiscollection of poems in which the types of poems have been named appropriately and to some extent,they have been introduced in this same book(Dastar nama) too.
\end{abstract}




\title{
Unconditional expediencies as a resource \\ Of legal system from point of Islam
}

\author{
Prf. Dad Mohammad Nazir \\ Faculty of Islamic Law \\ Kabul University
}

\begin{abstract}
:
Islam is a religion which secures five general necessities of human being; provided that the doors of practice of divine science have to be opened for those practicing religious jurisprudence and clergymen existed whenever, and wherever.

Who has the quality of practicing divine science can derive decisions from Islamic resources like the Quran and the Hadeth, solve people's problems in deferent aspects of five, and maintain specialty of eternity of Islam. But practice of divine science is legitimate provided that it isn't opposite Islamic general philosophy; it has to be according to Islamic principles, and to secure people's economical, political and social interests.
\end{abstract}

To be able becoming to give an opinion on religious law has a lot of methods. One of them is unconditional expediencies. As we said in the text, people's interests depend on necessary, requirement, or decorative affairs and Islamic principles came to guarantee above mentioned affairs. So we can say indeed Sharia Law established on the norm of "attracting the convenience and repelling depravities".

Although the Islamic jurisprudents disagree about legality of unconditional expediencies as a resource of Sharia Law, but the majority of them According to causes which we mentioned in the text say unconditional expediencies is a resource of Sharia Law. Laws which are taken from the Quran and the Hadeth by unconditional conveniences are two kinds:

1. Precepts that guarantee social interests.

2. Ordinances which belong to judicial affairs and private rights.

Legitimacy of doing according unconditional expediencies isn't absolute, but it has conditions. Practicing according unconditional expediencies is lawful only in the civil cases.

Islamic religious is providing gencral necessities of human being, doors of practice of divine science are opened for those practicing religious jurisprudence and they existing whenever, and wherever. To be able practicing divine science has a lot of methods. One of them is unconditional expediencies. 
Pohandoi Mir Akram Mirzad

Department of psychology

Faculty of psychology And Educational science

Kabul University

\begin{abstract}
:
Psychological requirement of Acutance period:

The article which the concept has mentioned it certifies the human ideology and education from the point of humanity.

The basic needs of adolescence which mentioned in the article it reflects the truth this age in this period of adolescence have some particular aspects. therefore \& belief self respect ,self confident, self esteem, self recognizing, self actualization \& life balance self knowing in society etc.
\end{abstract}

Key words: - The diagnosing of basic needs of adolescences period target, principle of methods and results. 


\title{
Effect of soil moisture depletion on dry matter production and yield of wheat plant
}

\author{
Pohandoy Dr. Amirjan Saidi \\ Department of Agronomy \\ Faculty of Agriculture \\ Kabul University
}

\begin{abstract}
:
In this research, the effects of soil moisture depletion for about one month before heading on dry matter and yicld of wheat were evaluated. It is well known that plants develop a better root system well under deficient soil moisture conditions and that plants can avoid water stress with the reduction of soil moisture compared with plants with poorly developed root system. The yield in the D plot was $5 \%$ higher than those in the $\mathrm{W}$ plot, although there was not significant difference in yield between the $\mathrm{W}$ and $\mathrm{D}$ plots. The harvest index in the $\mathrm{D}$ plot tended to be higher than those in the W plot although there was not significant difference between W and D plots. But we can not observe difference in dry weight of above ground parts between the plants. In the yield component, the grain number per square meter tended to be higher in the $\mathrm{W}$ plot than those in the $\mathrm{D}$ plot because of larger number of spike per square meter. No differences were observed in plant height, leaf expansion rate and number of stem between $\mathrm{W}$ and $\mathrm{D}$ plots. Treatment started on March 8, thereafter leaf xylem water potential decreased in the plant of the D plot with reduction in soil moisture until on April 28 and reached (-1.08MPa), after that the leaf water potential increased in the plant of $D$ plot. The leaf area index of plant in the $\mathrm{W}$ plot was higher than that in the $\mathrm{D}$ plot at heading stage; this difference resulted from the smaller reduction in stem number after the maximum tillering had been reached. The soil moisture at depth of $30 \mathrm{~cm}$ was kept $-0.01 \mathrm{MPa}$ during the treatment in the W plot. On April 29, the resistance increased, the increase in the resistance was largest at depth of $15 \mathrm{~cm}$ and the smallest at depth of $50 \mathrm{~cm}$. The leaf water potential of the plant in the D plot was decreased and lower than the W plot on April 28 during the heading stage. The plant in $\mathrm{W}$ plot in the field, leaf expansion and diffusive conductance in the early afternoon were affected when soil moisture and the leaf xylem water potential decreased.
\end{abstract}




\title{
Effect of different distance and weight of saffron corms on yield
}

\author{
Associate Prof. Gul Ahmad Zahiryan \\ Dept. of Horticulture \\ Faculty of Agriculture \\ Kabul University
}

\begin{abstract}
:
Effect of cultivated distance on number of flower per plot

Kabul experiment: Number of flower per plot in $5 \mathrm{~cm}$ cultivated distance $(53,3)$,in $10 \mathrm{~cm}$ cultivated distance $(42.2)$, in $15 \mathrm{~cm}$ cultivated distance(38.2)flower per plot produced. Probably $99 \%$ significant is between deferent distances. Number of flower per plot in deferent weight of saffron corms are significant in smallest weight $6 \mathrm{gr}$ weight produced (24.1) flower, in $9 \mathrm{gr}$ weight produced (46.7) flower and in $11 \mathrm{gr}$ weight produced (72.6) flower per plot. Probably 99\%significant is between deferent weights.

Medan wordak experiment: Number of flower per plot in $5 \mathrm{~cm}$ cultivated distance (47.3), in $10 \mathrm{~cm}$ cultivated distance(41.2), in $15 \mathrm{~cm}$ cultivated distance(38.3)flower per plot produced. Probably $99 \%$ significant is between deferent distances. Number of flower per plot in deferent weight of saffron corms are significant in smallest weight $6 \mathrm{gr}$ weight produced (22.2) flower, in $9 \mathrm{gr}$ weight produced (38.2) flower and in 11 gr weight produced (75.7) flower per plot. Probably $99 \%$ significant is between deferent wcights.

\section{Effect of cultivated distance on number of flower per plant}

Kabul experiment: Number of flower per plant in $5 \mathrm{~cm}$ cultivated distance(1.1),in $10 \mathrm{~cm}$ cultivated distance(1.1), in $15 \mathrm{~cm}$ cultivated distance(1.4)flower per plant produced. Probably 99\%significant is between deferent distances. Number of flower per plant in deferent weight of saffron corms are significant in smallest weight 6gr weight produced (0.6) flower, in 9gr weight produced (1.3) flower and in $11 \mathrm{gr}$ weight produced (1.9) flower per plot. Probably $99 \%$ significant is between deferent weights.Medan wordak experiment: Number of flower per plant in $5 \mathrm{~cm}$ cultivated distance $(0.6)$, in $10 \mathrm{~cm}$ cultivated distance(1), in $15 \mathrm{~cm}$ cultivated distance(1.4) flower per plant produced. Probably $99 \%$ significant is between deferent distances. Number of flower per plant in deferent weight of saffron corms are significant in smallest weight $6 \mathrm{gr}$ produced (0.5) flower, in $9 \mathrm{gr}$ weight produced (0.9) flower and in 11 gr weight produced (1.8) flower per plant. Probably $99 \%$ significant is between deferent wcights. Estimatedyield/J:

Kabul experiment: Yield/J differed significantly due to dry saffron weight per jereb
\end{abstract}


in $5 \mathrm{~cm}$ cultivated distance produce ( $789.4 \mathrm{gr})$, in $10 \mathrm{~cm}$ cultivated distance produce (639.5gr), in $15 \mathrm{~cm}$ cultivated distance produce $(565.3 \mathrm{gr})$ dry saffron per jereb. Probably $99 \%$ significant is between deferent cultivated distances. Yield per jereb in deferent weight of saffron corms are significant. In smallest $6 \mathrm{gr}$ weight produced (357.1gr), in 9gr corms weight produced (691.3gr) and in 11gr weight produced (1074gr) saffron. Probably 99\%significant is between deferent weights.

Medan wordak experiment: Yield/J differed significantly due to dry saffron weight per jereb in $5 \mathrm{~cm}$ cultivated distance produce $(700.4 \mathrm{gr})$, in $10 \mathrm{~cm}$ cultivated distance produce $(610.7 \mathrm{gr})$, in $15 \mathrm{~cm}$ cultivated distance produce (568gr)dry saffron per jereb. Probably $99 \%$ significant is between deferent cultivated distances. Yield per jereb in deferent weight of saffron corms are significant. In smallest $6 \mathrm{gr}$ corms weight produced (329.2gr), in 9 gr corms weight produced (566.2gr) and in $11 \mathrm{gr}$ weight produced (1121gr) saffron: Probably $99 \%$ significant is between deferent weights. 


\title{
Ahmad Shah Zagham \\ Faculty of language and literature
}

Department of pashto

Kabul University

\begin{abstract}
:
The content of Rahman Baba's poetry is clear to everyone. He says:

Is this your poetry or a miracle?

That even a dissenter can't object on thiat Rahman Baba's poetry offers high moral criteria to people. These critera have been stated by technical and sweet language of poetry. He explores human beings belife nature so skillfully that everyone who reads these poetry can use them as a guide for their life.

The content of his poetry is complete and is offered to the society through simple and sweat language. I have chosen just a part of that for research.
\end{abstract}




\title{
Extension and development of Fishery in Afghanistan
}

\author{
Pohanwail Zaiudain Zia \\ Departmcnt of Animal Science \\ Faruity of Agriculiture \\ Kabul University.
}

\begin{abstract}
:
Fish is generally regarded as a primary source of Arimal protein. Fish prcvides about 6 percent of total protein needed by human and 24 percen of Animal protein in world.

Regarding, Geographic location and weather condition, Afghanistan is a proper region for raising both cold and warm water fishes.

According to survey, Parwan, Kabul, Kunduz,Juzjan, Surpul, baghlan, Panjsher and Takhar provinces are proper regions for cold and Nangahar, Laghman and Kunur for warm water fishery.

Rehabilitation and development of fishery sector which was distorted during wars is started recently. French cooperation department for ministry of agriculture and some others donors are contributing for this purpose.

In this paper the important and possibilities of further devclopment of fishery sector in Afghanistan are discussed.
\end{abstract}




\section{Life and energy \\ Prof.Abdul Salam"Mamakhil" \\ Department of Animal science \\ Agriculture college \\ Kabul University}

\section{Abstract:}

Change in free encry is calleci $\Delta G^{0}$, expressed in calories per mole. Negative $\Delta G^{o}$ shows exergonic reaction or sporitaneous reaction .

Posiive $\Delta G^{6}$ shows endergonic reaction.

Hydrolysis of ATP always produce energy $-7.3 \mathrm{kcal} / \mathrm{M}$ on hydrolysis ATP produce either ADP and Pi or AMP and ppi the later reaction is irreversible reaction.

Other biomolecules such as 1.3 biophosphoglyceris acid of factors that can account for the large negative $\Delta G$.

Example are bond stain in the reaction because of internal electrostatic repulsion, ionization or isomerixation of the products stabilization of the product by resonance forms.

ATP is the principle phosphate group donor for the production of the deoxyribonucleoside diphosphate in to deoxy ribonucleoside diphosphateds. Which catalyses by nucleoside diphosphate kinase. 


\section{فعاليتهاي مز كز ملهي تعقيقات زئلميبهى}

\section{يوهنتون كابل}

نشرات جديد مركز ملى تحقيقات ياليسى

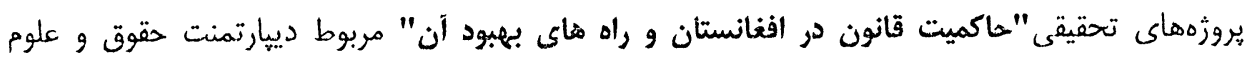

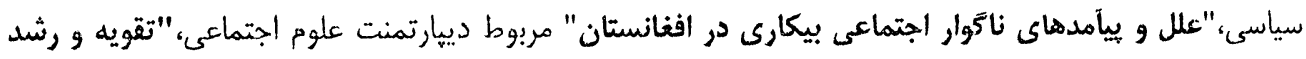

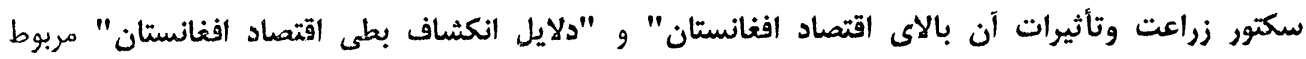

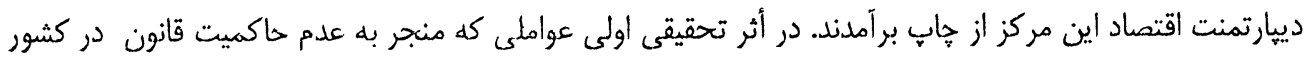

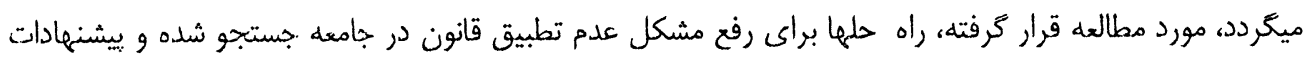

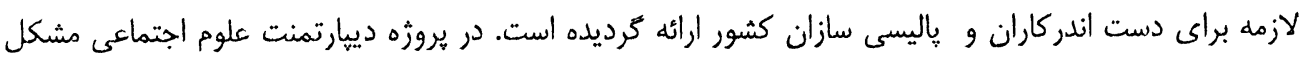

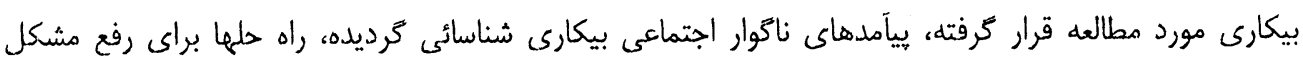

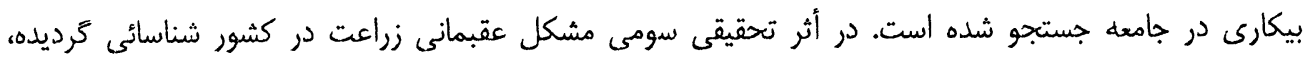

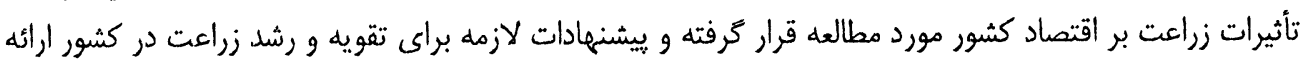

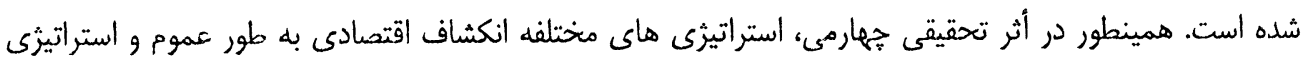

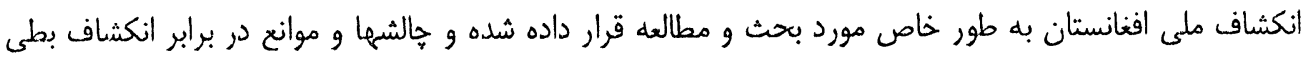

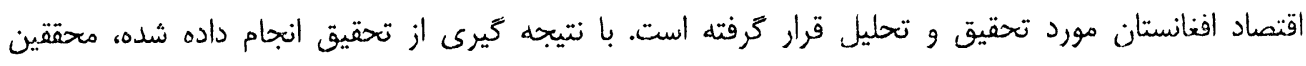

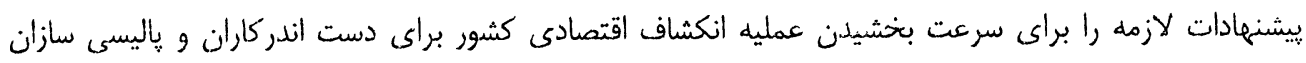
كشور ارائه نموده اند.

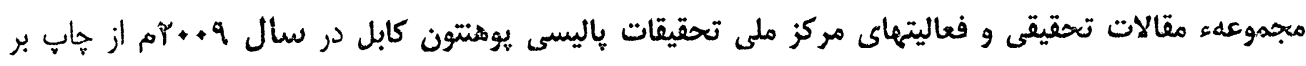

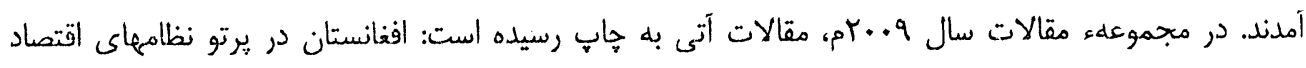

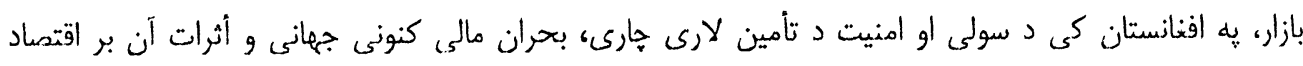

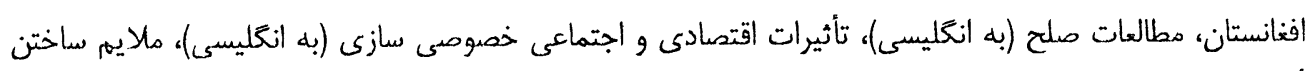

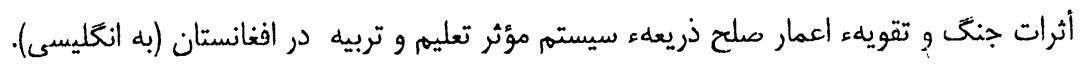

\section{مخفل اختتاميه برنامه كَارف در يوهنتون هرات}

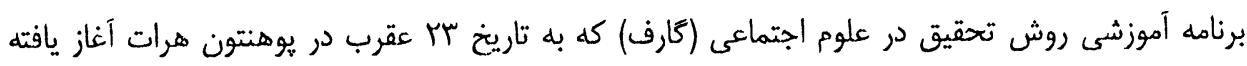

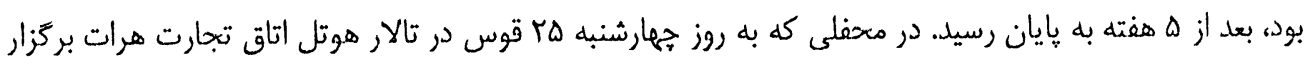

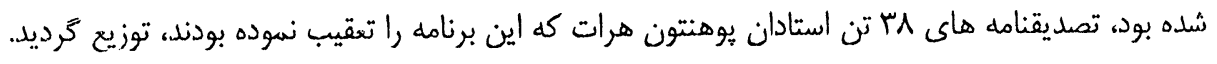




\section{نشستهاى كارى براى انتخناب عناوين تحقيقى سال • 1+ Tم}

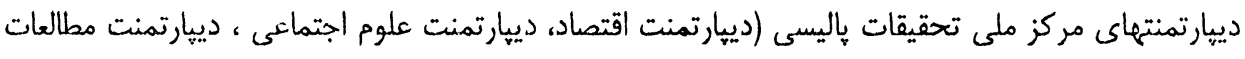

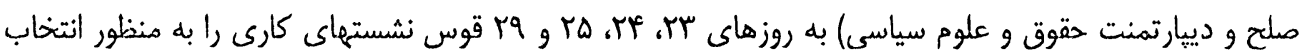
عناوين تحقيقى سال •1 • ام بركزار نمودند.

اشتراك كنندكان اين نشستهاى كارى در مورد هر ها عنوان تحقيقى از هر دييارتمنت بحث و ابراز نظر نموده و در

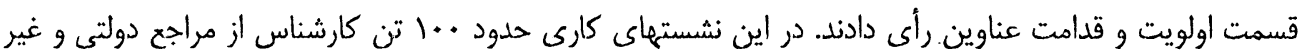

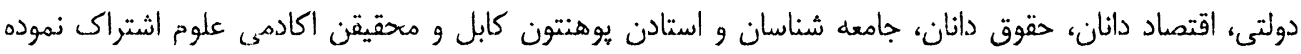

\section{برنامد تارف در يوهنتون كندهار}

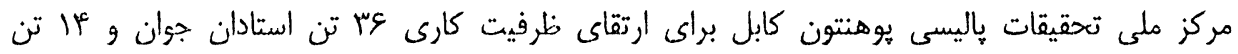

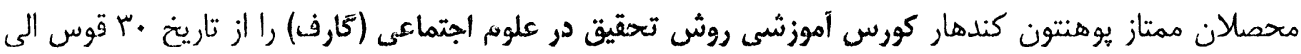
צ جدى در آن يوهنتون داير نمود.

\section{دومين سمينار ارتقاى ظرفيت كارى براى كار مندان دولتى ولايت ارزكان}

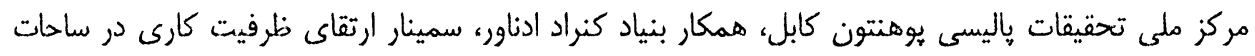

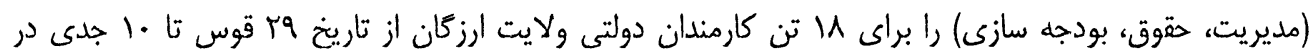

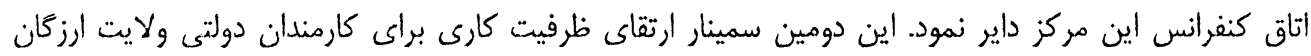

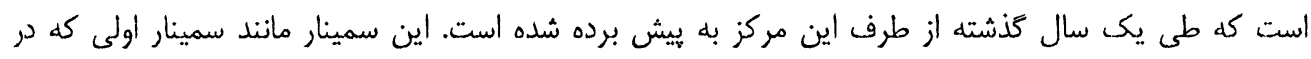

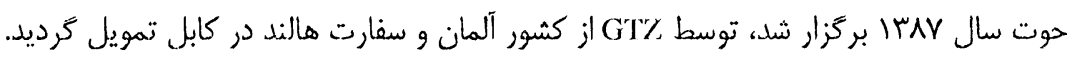

\section{نشستهماى كارى ديبار تمنت مطالحات هلح}

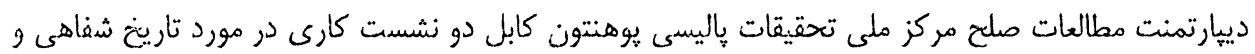

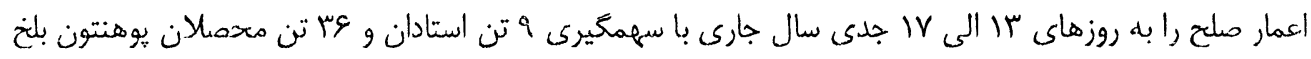

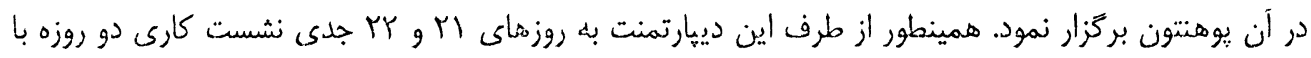

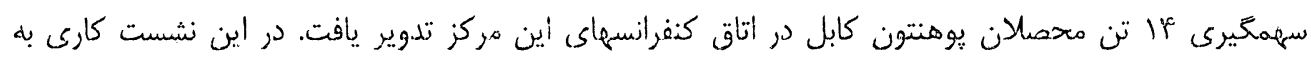

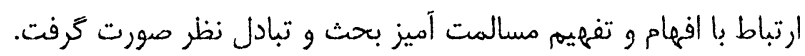

\section{يورزه تحقيقى راه ها به سوى ملغ در افغانستان}

مركز ملى تحقيقات ياليسى يوهنتون كابل و انستيتوت اعمار صلح از كشور كانادا يروزه تحقيقى دو ماهه در

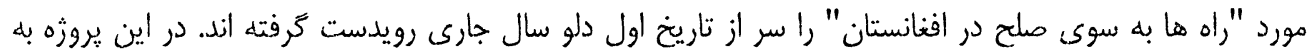


سطح سا ولايت كشور به شمول ولايت كابل تحقيقات ساحوى صورت كرفته و در مورد ها سؤال تحقيقى شامل

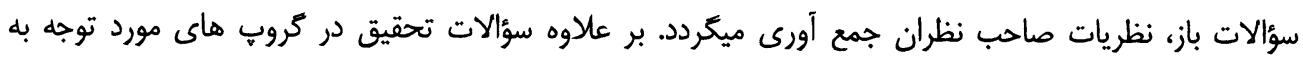

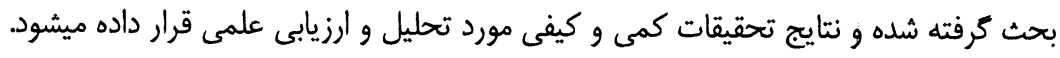

\section{عناوين تحقيقى سال +1 +}

دييارتمنتهاى مركز ملى تحقيقات ياليسى در سال • • إم يرورهه هاى تحقيقى آتى را به انجام خواهند رساند:

(. تأمين أمنيت توسط افغانها بعد از خروج عساكر خارجى از كشور (دييارتمنت حقوق و علوم سياسى)

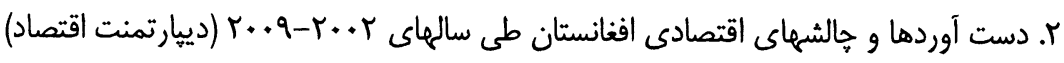

r. أثرات اجتماعى بركشت مهاجرين افغانى و بيجا شده كان داخلى در اماكن اصلى شان (دييارتمنت علوم

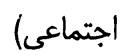

f. نقش علماى دينى و سران قومى در تقويه عمليهء صلح در افغانستان (دييارتمنت مطالعات صلح).

\section{ديدارهيأت عالى رتبه علمى پاكستان از يوهنتون كابل}

بناء به دعوت بنياد كنراد ادناور، همكار و تمويل كنندهء مركز ملى تحقيقات باليسى يوهنتون كابل يك هيأت

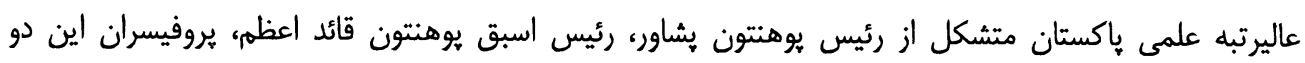

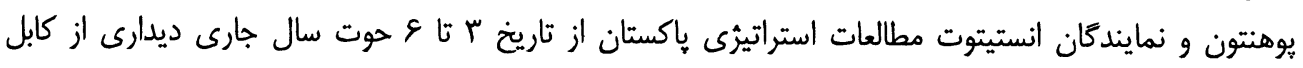

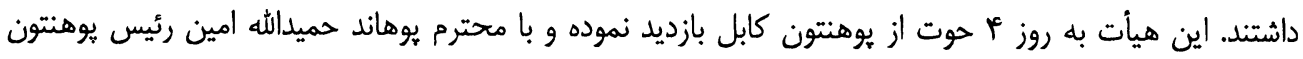

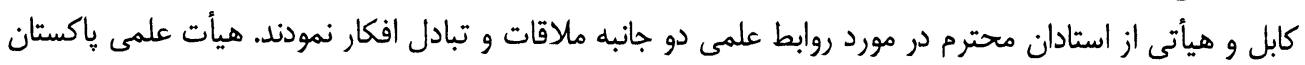

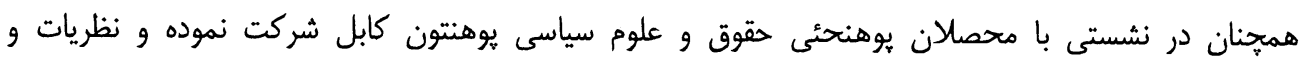
ييشنهادات محصلان را استماع نمودند.

\section{ميز مدور در مورد اخاذى هاى غير قانونى}

مركز ملى تحقيقات ياليسى يوهنتون كابل و مركز براى متشبثين خصوصى بين المللى دومين ميز مدور رابه

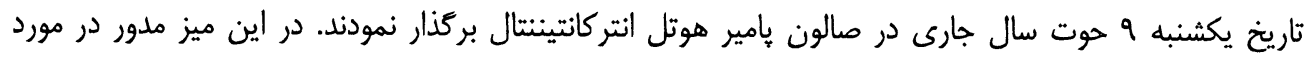

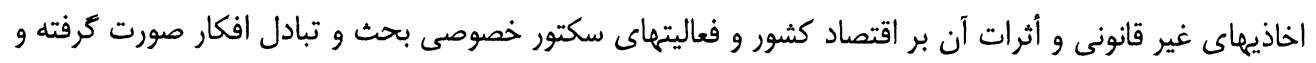

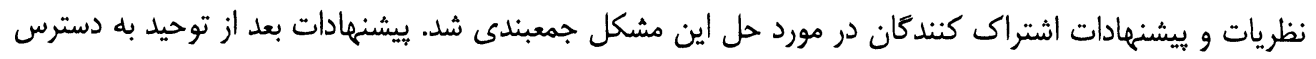

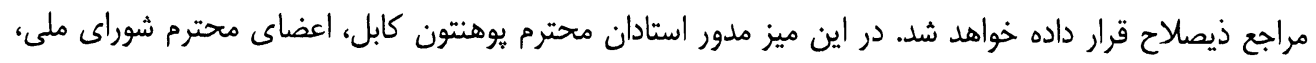

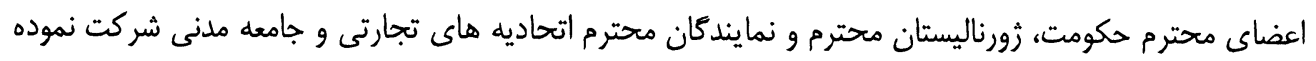

Y

,

مبله عالميوانتون

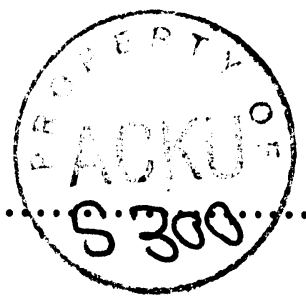
بودند. 


$$
\text { دو هابل يو هنتون ه مجله }
$$

$$
\text { لوه مباشتنى خبرونه }
$$

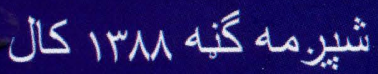

